Camila Oliveira dos Santos Alves

\title{
PESQUISA DE VARIANTES GENÉTICAS EM PACIENTES BRASILEIROS COM DISTONIA IDIOPÁTICA
}

Tese apresentada à Faculdade Israelita de Ciências da Saúde Albert Einstein para obtenção do Título de Doutor em Ciências da Saúde.

São Paulo 
Camila Oliveira dos Santos Alves

\section{PESQUISA DE VARIANTES GENÉTICAS EM PACIENTES BRASILEIROS COM DISTONIA IDIOPÁTICA}

Tese apresentada à Faculdade Israelita de Ciências da Saúde Albert Einstein para obtenção do Título de Doutor em Ciências da Saúde.

Orientadora: Profa. Dra. Patrícia Maria de Carvalho Aguiar 
A474p

Alves, Camila Oliveira dos Santos

Pesquisa de variantes genéticas em pacientes brasileiros com distonia idiopática / Camila Oliveira dos Santos Alves. -- São Paulo, 2019.

xvii, $123 \mathrm{f}$.

Tese (Doutorado) - Faculdade Israelita de Ciências da Saúde Albert Einstein. Instituto Israelita de Ensino e Pesquisa Albert Einstein. Programa de Pós-Graduação em Ciências da Saúde.

Título em inglês: Screening of genetic variants in Brazilian patients with idiopathic dystonia.

1. Distonia/genética. 2. Variação genética. 3. Transtornos do movimento.

NLM - WL 390

Elaborada pelo Sistema Einstein Integrado de Bibliotecas 
FACULDADE ISRAELITA DE CIÊNCIAS DA SAÚDE ALBERT EINSTEIN

Coordenador do Curso de Pós-Graduação: Prof. Dr Luiz Vicente Rizzo 
Camila Oliveira dos Santos Alves

\title{
PESQUISA DE VARIANTES GENÉTICAS EM PACIENTES BRASILEIROS COM DISTONIA IDIOPÁTICA
}

Presidente da banca: Profa. Dra. Patrícia Maria de Carvalho Aguiar

\author{
BANCA EXAMINADORA
}

Membros titulares:

Profa. Dra. Einat Hauzman

Profa. Dra. Elisa Harumi Kozasa

Profa. Dra. Sarah Teixeira Camargos

Membros suplentes:

Profa. Dra. Luciana Rosrigues Jacy da Silva

Profa. Dra. Raquel de Melo Alves Paiva

Aprovada em: 20/12/2019. 


\section{Agradecimentos}

Agradeço a Deus por ter me permitido viver esse momento.

À Profa. Dra. Patricia Aguiar, agradeço por ter me ensinado a aprender. Agradeço por todos os anos de parceria, orientação e por tudo que pacientemente me ensinou. Agradeço por ter me permitido participar desse projeto, por ter me proporcionado um ambiente de aprendizado e contribuição, no qual me senti útil e estimulada a dar meu melhor. Agradeço por todas as dicas, conselhos profissionais e acadêmicos e, além de tudo, por todo apoio e força nos momentos mais difíceis da minha vida.

Agradeço à Rede Brasileira para Estudos das Distonias (RBED) por suportar a realização desse projeto e por todo o empenho na investigação da distonia. Agradeço aos pacientes, familiares e controles pela essencial participação, assim como os pesquisadores e colaboradores associados Dra. Patricia Aguiar, Dr. Francisco Pereira da Silva Júnior, Dr. Egberto Reis Barbosa, Dra. Sônia Maria C. Azevedo Silva, Dra. Vanderci Borges, Dr. Henrique Ballalai Ferraz, Dra. Maria Sheila Guimarães Rocha e Dr. João Carlos Papaterra Limongi e suas respectivas instituições: Hospital Israelita Albert Einstein (Instituto do Cérebro), Universidade Federal de São Paulo (Departamento de Neurologia), Faculdade de Medicina da Universidade de São Paulo (Departamento de Neurologia), Hospital do Servidor Público Estadual (Departamento de Neurologia) e Hospital Santa Marcelina.

Agradeço à Faculdade Israelita de Ciências da Saúde Albert Einstein e ao Hospital Israelita Albert Einstein pelo excelente programa de Pós-Graduação, por toda a infraestrutura e aparato laboratorial e de suporte à pesquisa. Agradeço ao coordenador Dr. Luiz Vicente Rizzo, a todos os docentes e toda a equipe de suporte acadêmico, laboratorial e de apoio à pesquisa científica.

Agradeço ao Renato David Puga pela colaboração e contribuição nas análises bioinformáticas dos dados de sequenciamento.

Agradeço aos profissionais do setor de sequenciamento genético do laboratório clínico por permitirem o uso do sequenciador MiSeq.

Agradeço aos professores e pesquisadores que participaram da banca examinadora desse trabalho Prof. Dr. André Felício, Profa. Dra. Andrea Sertie, Dra. Andrea Vieira, Profa. Dra. Einat Hauzman, Profa. Dra. Elisa Harumi Kozasa, Profa. Dra. Gisele Sampaio e Profa. Dra. Sarah Camargos. 
Agradeço aos meus colegas de grupo e Pós-Graduação pelo compartilhamento de conhecimento e apoio.

Agradeço à minha família por todo apoio, compreensão e incentivo.

Por fim, declaro meu agradecimento especial às entidades que fomentam a pesquisa científica no Brasil. Agradeço o Conselho Nacional de Desenvolvimento Científico e Tecnológico (CNPq), a Coordenação de Aperfeiçoamento de Pessoal de Nível Superior (CAPES) e, sobretudo, a Fundação de Amparo à Pesquisa do Estado de São Paulo (FAPESP) por viabilizar esse estudo através de apoio financeiro, possibilitando a dedicação exclusiva para a realização do mesmo (Processos FAPESP o 2014/17128-2 e 2016/17211-2). O presente trabalho foi realizado com apoio da Coordenação de Aperfeiçoamento de Pessoal de Nível Superior - Brasil (CAPES) - Código de Financiamento 001. 


\section{Sumário}

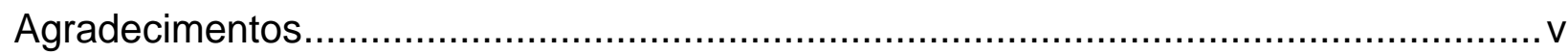

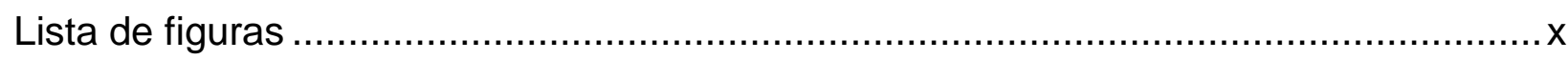

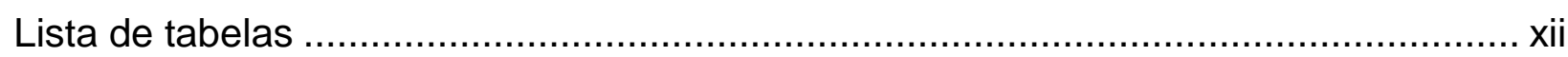

Lista de abreviaturas e símbolos ............................................................ xiii

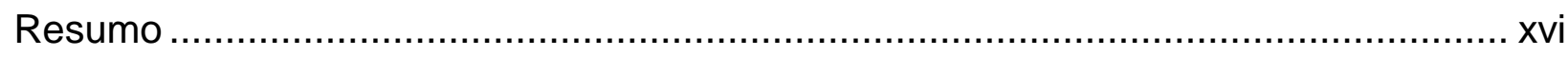

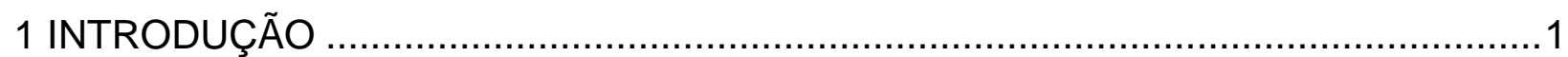

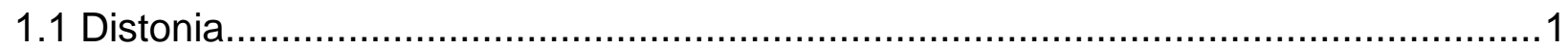

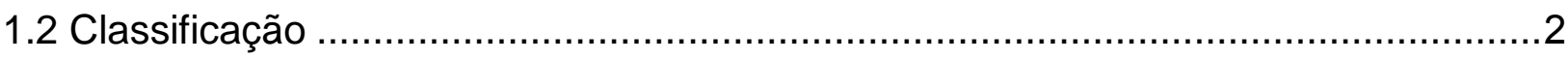

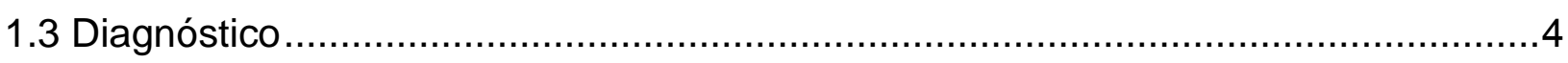

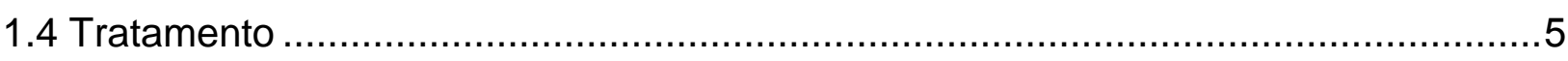

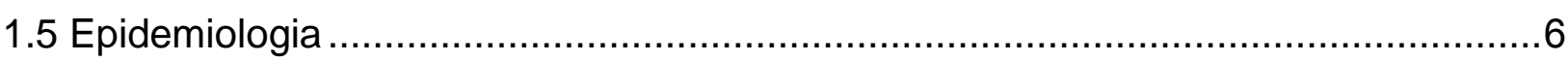

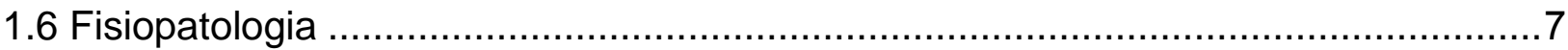

1.7 Estruturas anatômicas envolvidas ..................................................................

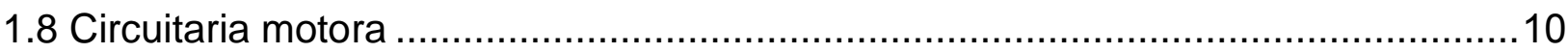

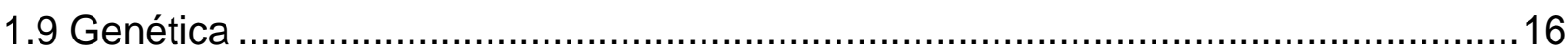

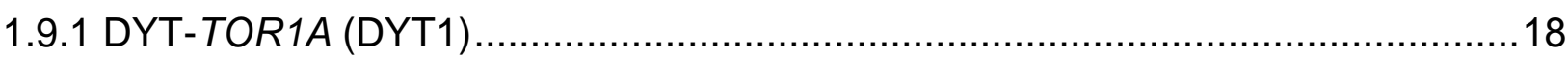

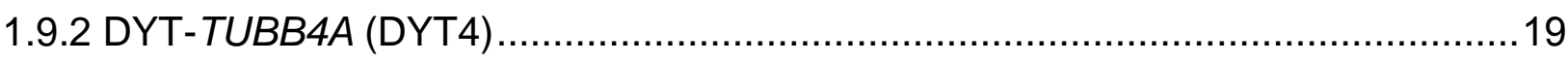

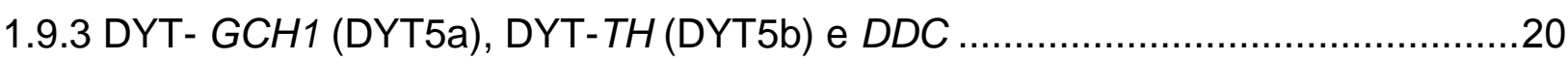

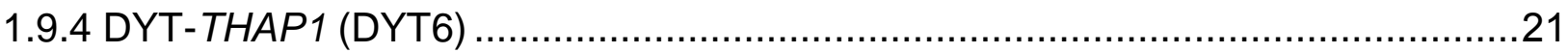

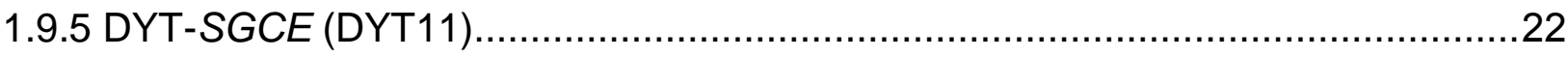

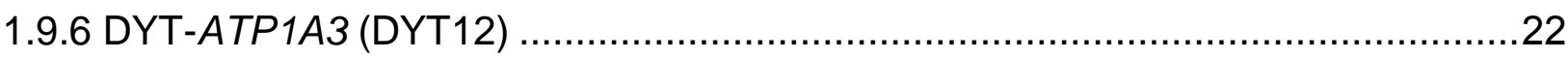

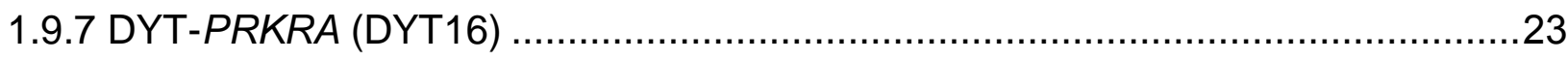

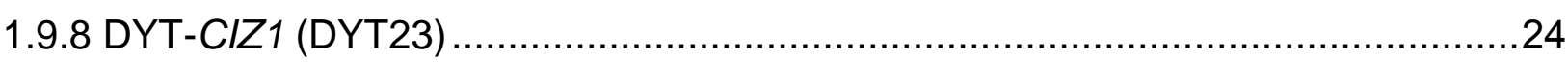

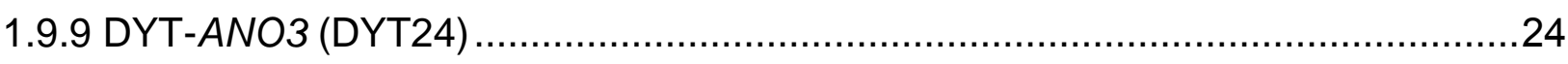

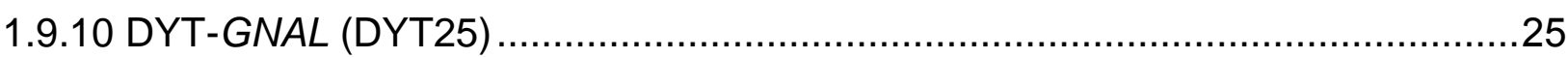

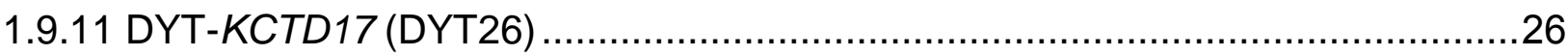

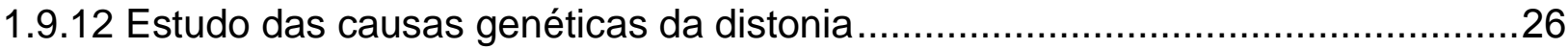

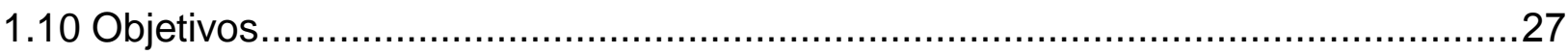

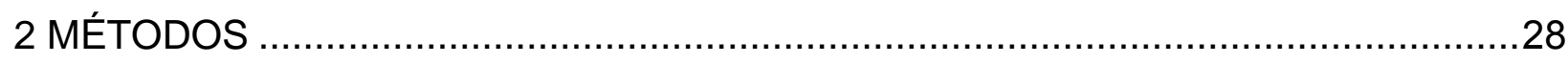

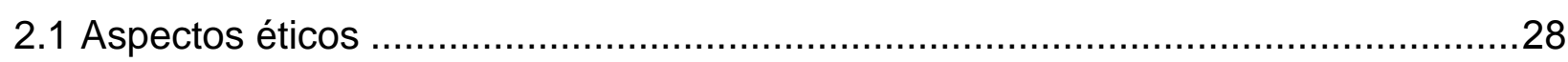

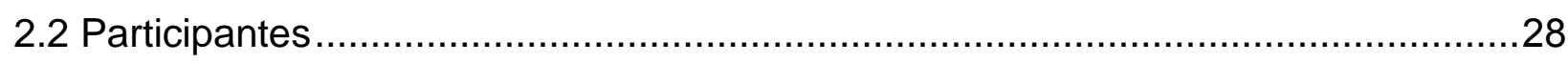




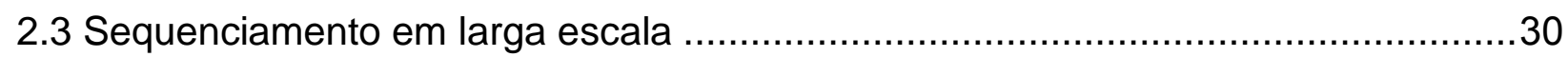

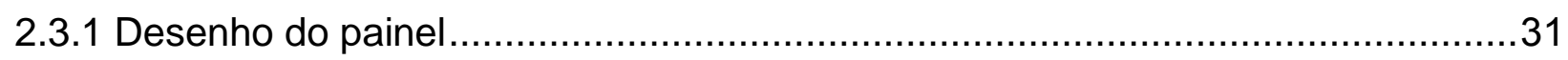

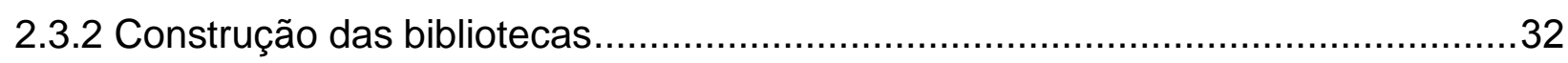

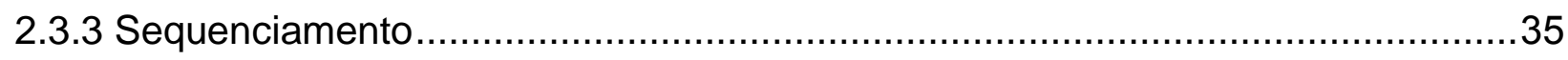

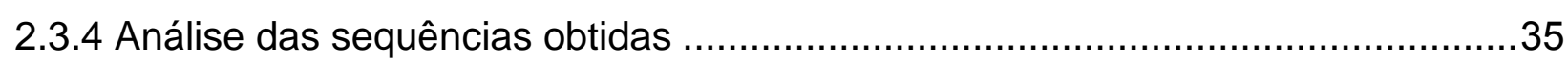

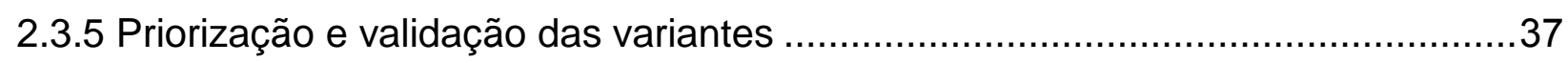

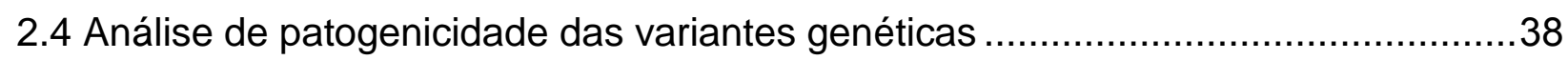

2.4.1 Frequência da variante em bancos de dados populacionais ..............................39

2.4.2 Conservação do aminoácido ao longo da evolução ............................................41

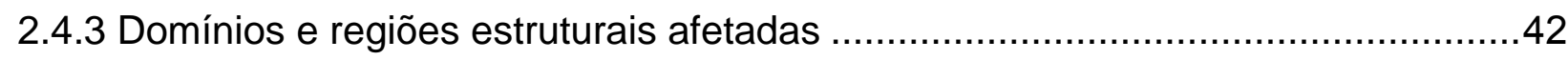

2.4.4 Análises in silico de predição de patogenicidade ............................................42

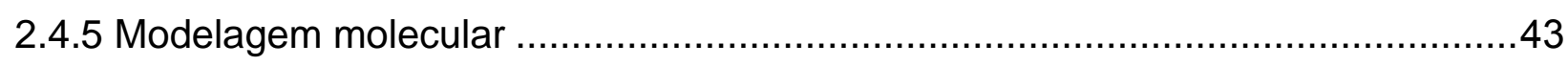

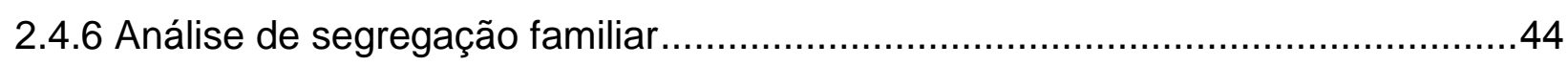

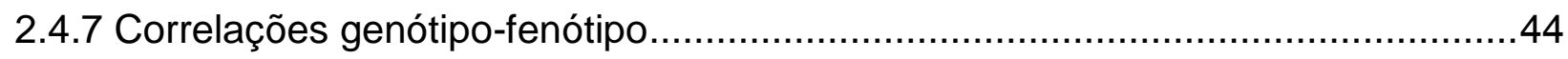

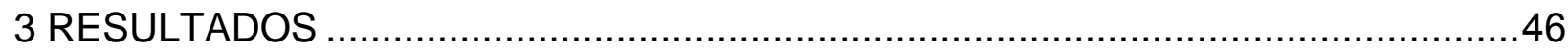

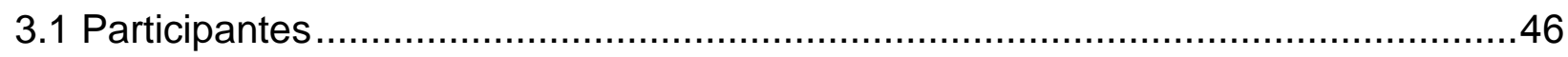

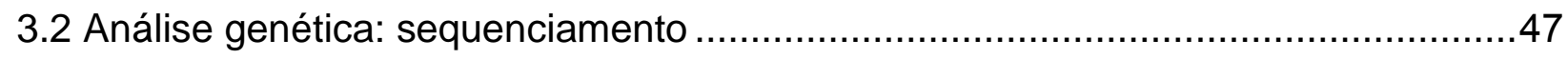

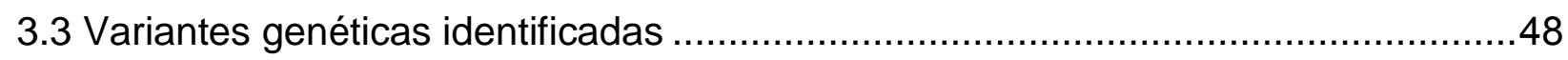

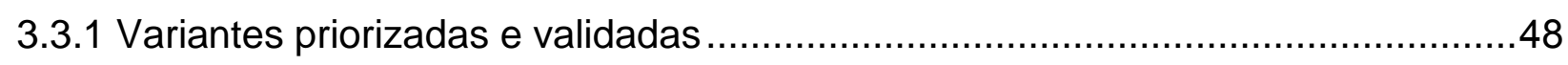

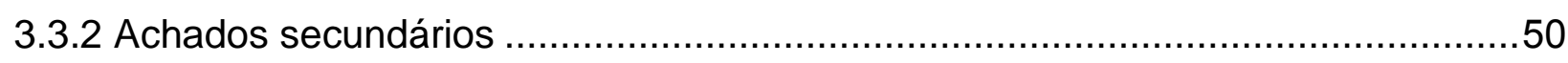

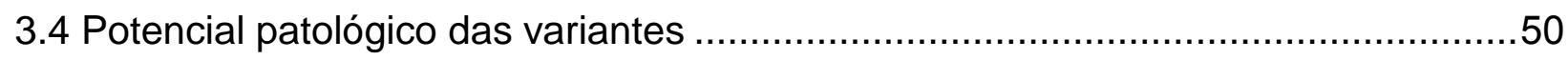

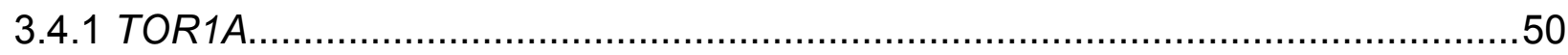

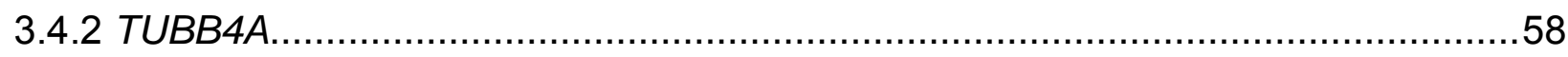

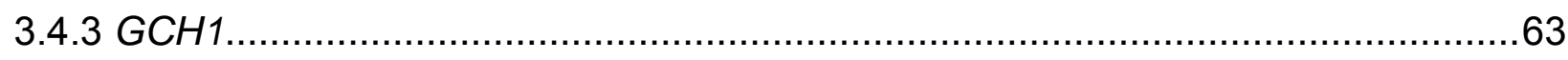

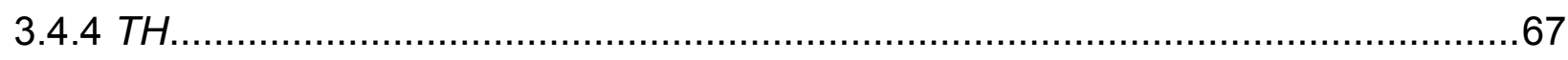

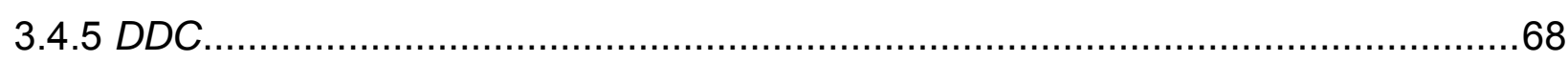

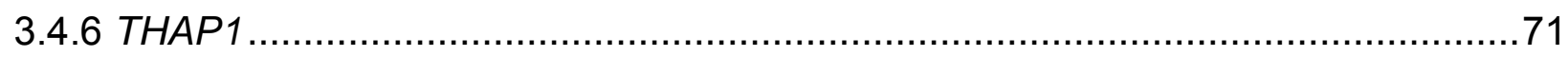

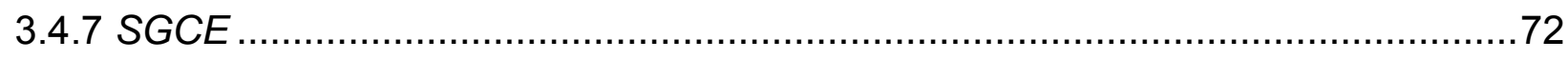

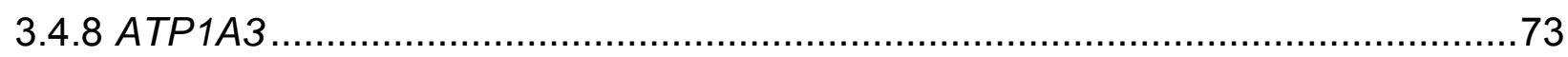

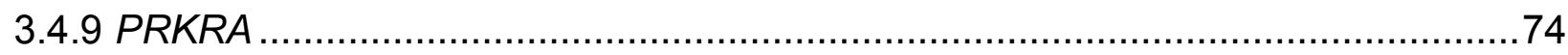

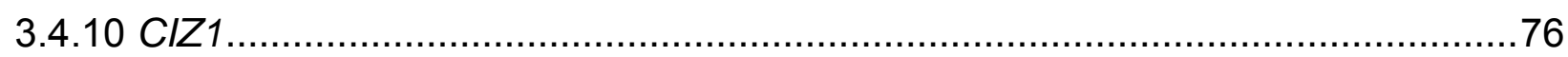

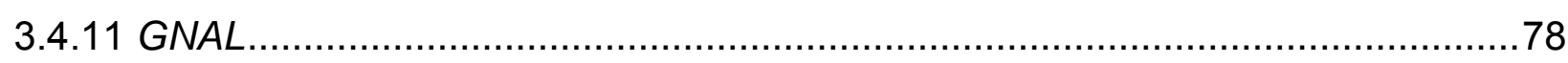

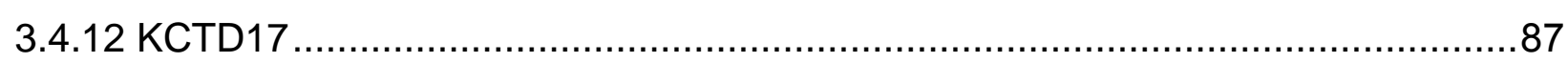

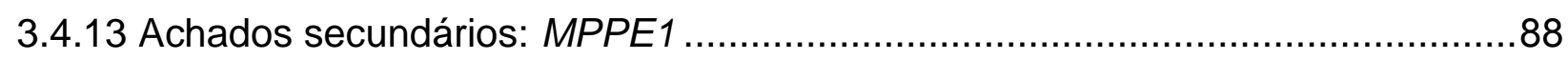


3.5 Caracterização fenotípica dos probandos e correlação com o genótipo ……….......89

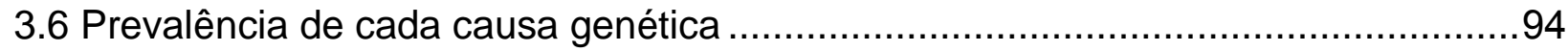

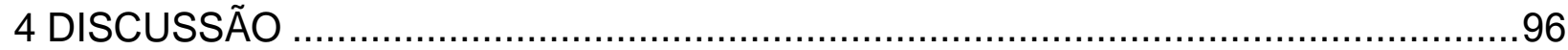

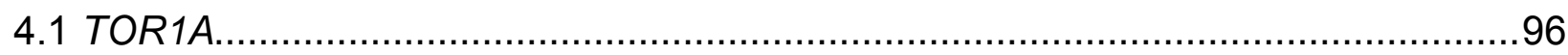

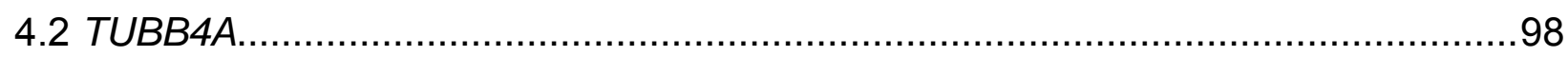

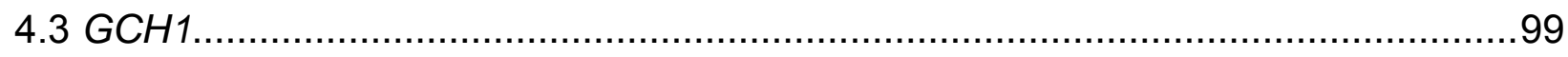

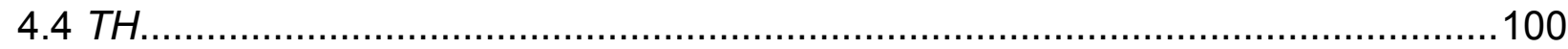

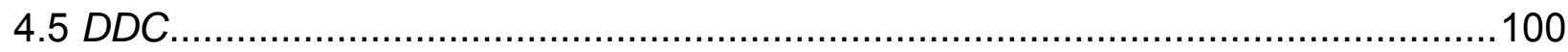

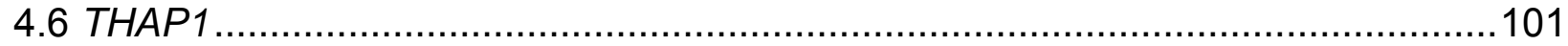

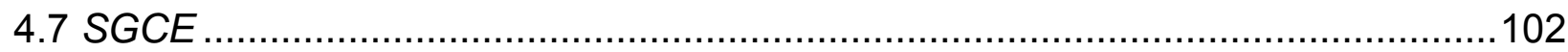

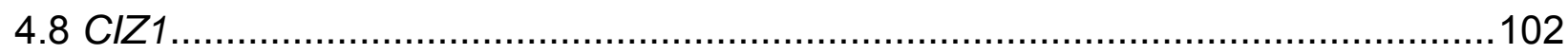

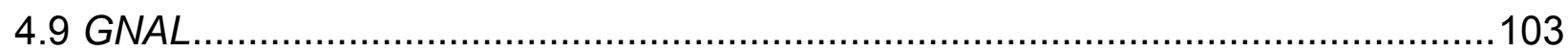

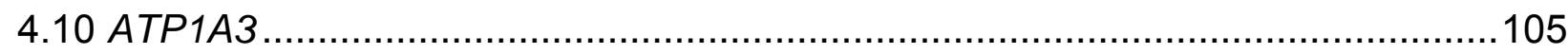

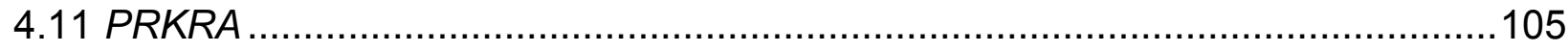

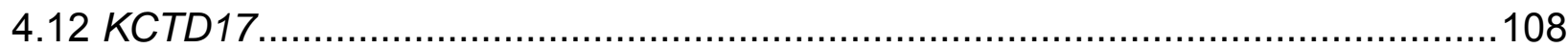

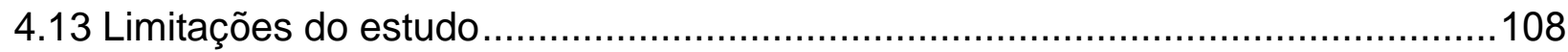

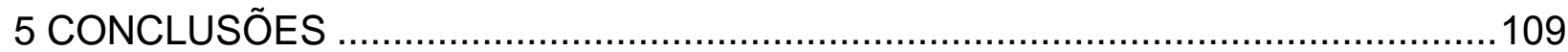

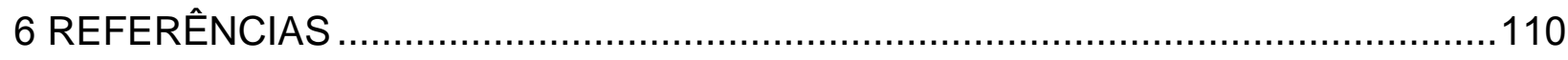

Abstract 


\section{Lista de figuras}

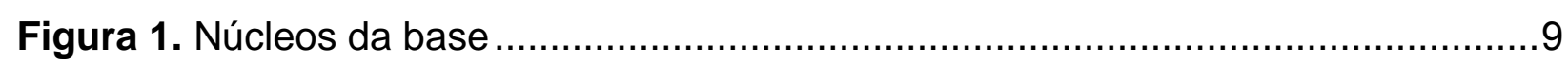

Figura 2. Circuito córtex - núcleos da base - tálamo …..........................................10

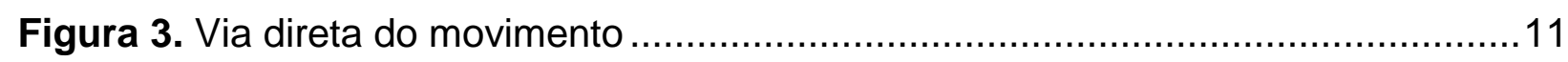

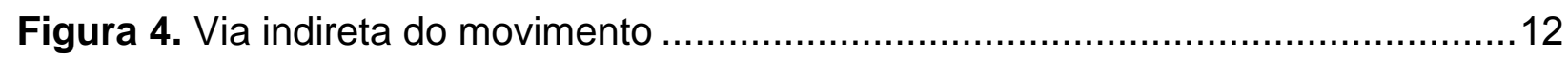

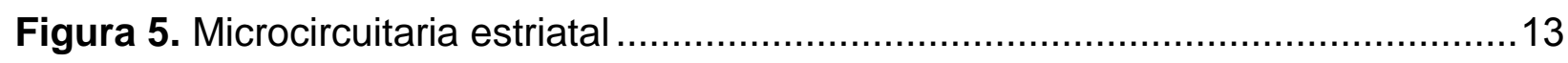

Figura 6. Mecanismo fisiopatológico de perda de inibição em distonia ........................15

Figura 7. Seleção amostral dos indivíduos com distonia incluídos nesse estudo ..........30

Figura 8. Etapas da tecnologia de ressequenciamento direcionado por amplicons .....34

Figura 9. Processo de análise bioinformática das sequências obtidas e priorização das

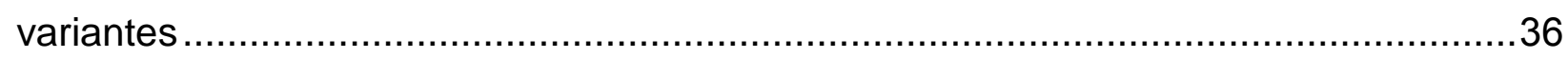

Figura 10. Classificação taxonômica das espécies selecionadas e grau de conservação dos genes de interesse ao longo da evolução........................................................ 41

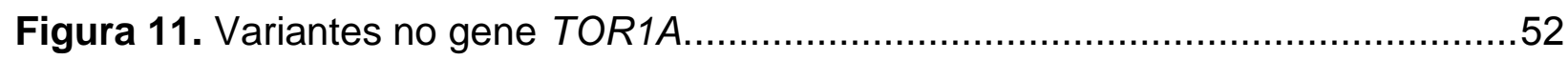

Figura 12. Sequência sinalizadora e região transmembrana da proteína torsina $1 \mathrm{~A}$....53

Figura 13. Regiões de interação proteica da proteína torsina $1 \mathrm{~A}$................................53

Figura 14. Sítios de ligação de ATP preditos nos modelos da proteína torsina 1 A ......54

Figura 15. Posição das variantes nos modelos proteicos da torsina $1 \mathrm{~A}$.......................54

Figura 16. Alterações nas interações entre os resíduos adjacentes à variante

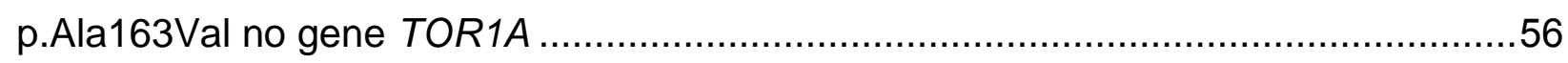

Figura 17. Alterações nas interações entre os resíduos no modelo com a variante

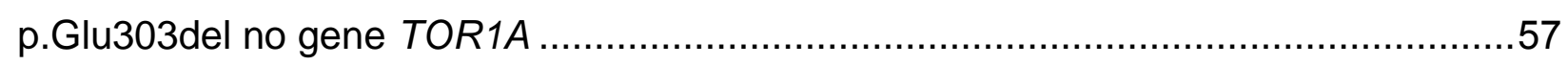

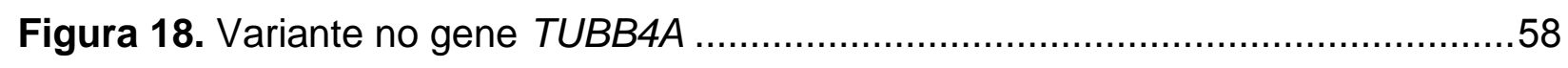

Figura 19. Heredograma do probando TUBB4A / ATP1A3 ......................................59

Figura 20. Modelo 3D de TUBB4A baseado na estrutura C2p4nB (TUBB2B).............60

Figura 21. Comparação entre o modelo TUBB4A selvagem e o variante D295N ........61

Figura 22. Ponte de hidrogênio de estrutura terciária perdida nos modelos TUBB4A

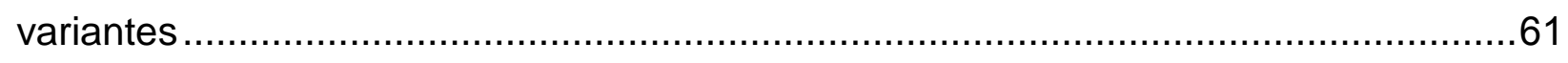

Figura 23. Proteína TUBB4A em superfície com regiões de loop destacadas .............62

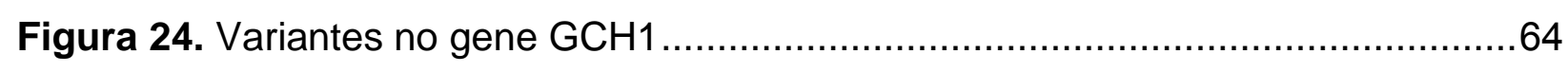

Figura 25. Alterações conformacionais e nas ligações por pontes de hidrogênio no modelo GCH1 com a variante p.P147S ...............................................................66

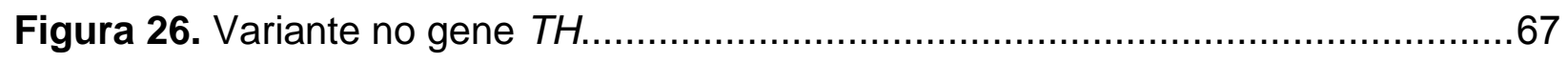




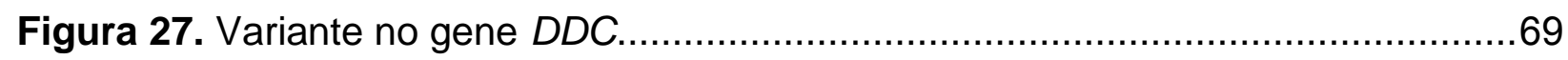

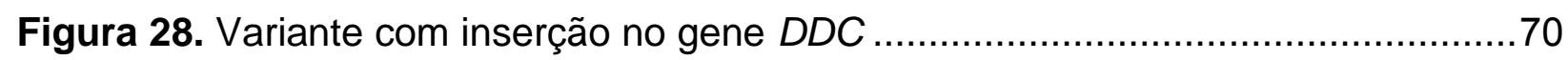

Figura 29. Heredograma do probando com inserção no gene $D D C$.............................70

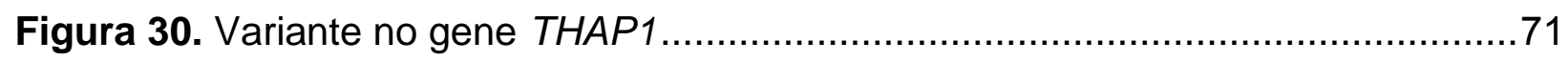

Figura 31. Variante no gene SGCE ............................................................ 72

Figura 32. Variantes no gene ATP1A3 .......................................................... 73

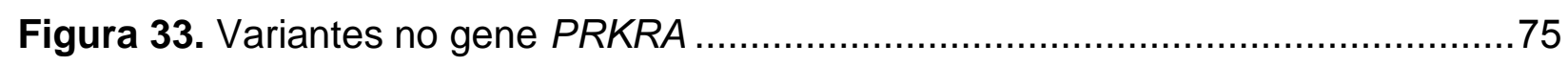

Figura 34. Diferenças no padrão de expressão do gene $C I Z 1$...................................76

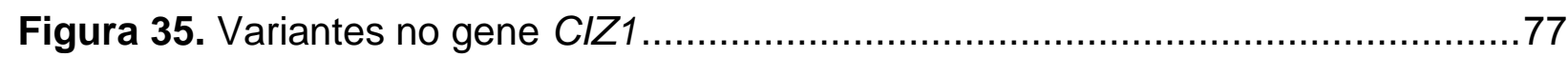

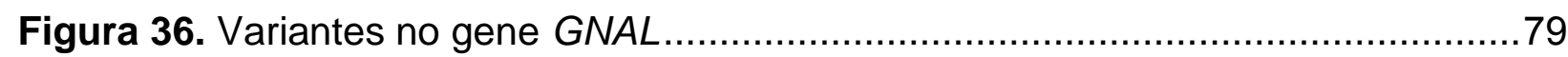

Figura 37. Região de interações da proteína Gaolf com as subunidades $\beta y$, com o receptor putativo e a proteína efetora adenilato ciclase ............................................ 81

Figura 38. Sítios ligantes de GTP na proteína Gaolf (GNAL) ….............................. 81

Figura 39. Regiões de alterações conformacionais na proteína Goolf mediante ativação por GTP

Figura 40. Consequências moleculares na interação entre estruturas secundárias no modelo proteico GNAL com a variante p.Asp220Tyr.

Figura 41. Esquema representativo da interação entre as estruturas secundárias da proteína Gaolf. .84

Figura 42. Perda de interações entre as $\alpha$-hélices e loop da proteína Gaolf. .85

Figura 43. Perda de interações da fita $\beta$-pregueada 5 da proteína Gaolf .86

Figura 44. Perda de interações entre loops de alteração conformacional após ativação da proteína Gaolf .86

Figura 45. Variantes no gene KCTD17. .87

Figura 46. Distribuição das variantes genéticas potencialmente patogênicas e dos casos que permaneceram idiopáticos por faixa etária. .93

Figura 47. Frequência de cada causa genética de distonia no grupo amostral .94 


\section{Lista de tabelas}

Tabela 1. Características clínicas dos probandos incluídos nesse estudo .46

Tabela 2. Variantes genéticas priorizadas e validadas 49

Tabela 3. Fenótipo dos probandos com variantes genéticas .90

Tabela 4. Conclusão das análises de patogenicidade e correlação dos genótipos com os fenótipos .92

Tabela 5. Características clínicas dos probandos com variantes no gene MPPE1......94

Tabela 6. Frequência total de cada causa genética conforme método de identificação95

Tabela 7. Genótipos de marcadores polimórficos na região genômica do PRKRA ....107 


\section{Lista de abreviaturas e símbolos}

\begin{tabular}{ll}
$\alpha$ & Alfa \\
$\beta$ & Beta \\
oC & Grau Celsius \\
$\mu$ L & Microlitro \\
A & Adenina \\
ABraOM & Arquivo Brasileiro Online de Mutações \\
ACMG & American College of Medical Genetics and Genomics \\
Ala & Alanina \\
AMP & Association for Molecular Pathology \\
Arg & Arginina \\
Asn & Asparagina \\
Asp & Aspartato \\
BipMed & Brazilian Initiative on Precision Medicine \\
BLAST & Basic Local Alignment Search Tool \\
C & Citosina \\
CADD & Combined Annotation Dependent Depletion \\
DBS & Deep Brain Stimulation \\
ddNTP & Didesoxirribonucleotídeo Fosfatado \\
DNA & Ácido Desoxirribonucleico \\
DNAg & DNA genômico \\
dNTP & Desoxirribonucleotídeo Fosfatado \\
ECP & Estimulação Cerebral Profunda \\
EDTA & Ácido Etilenodiamino Tetra Acético \\
ExAC & Exome Aggregation Consortium \\
G & Guanina \\
GABA & Ácido gama-aminobutírico \\
GATK & Genome Analysis Toolkit \\
GDP & Guanosina difosfato \\
Gln & Glutamina \\
Glu & Glutamato \\
Gly & Glicina \\
\hline
\end{tabular}




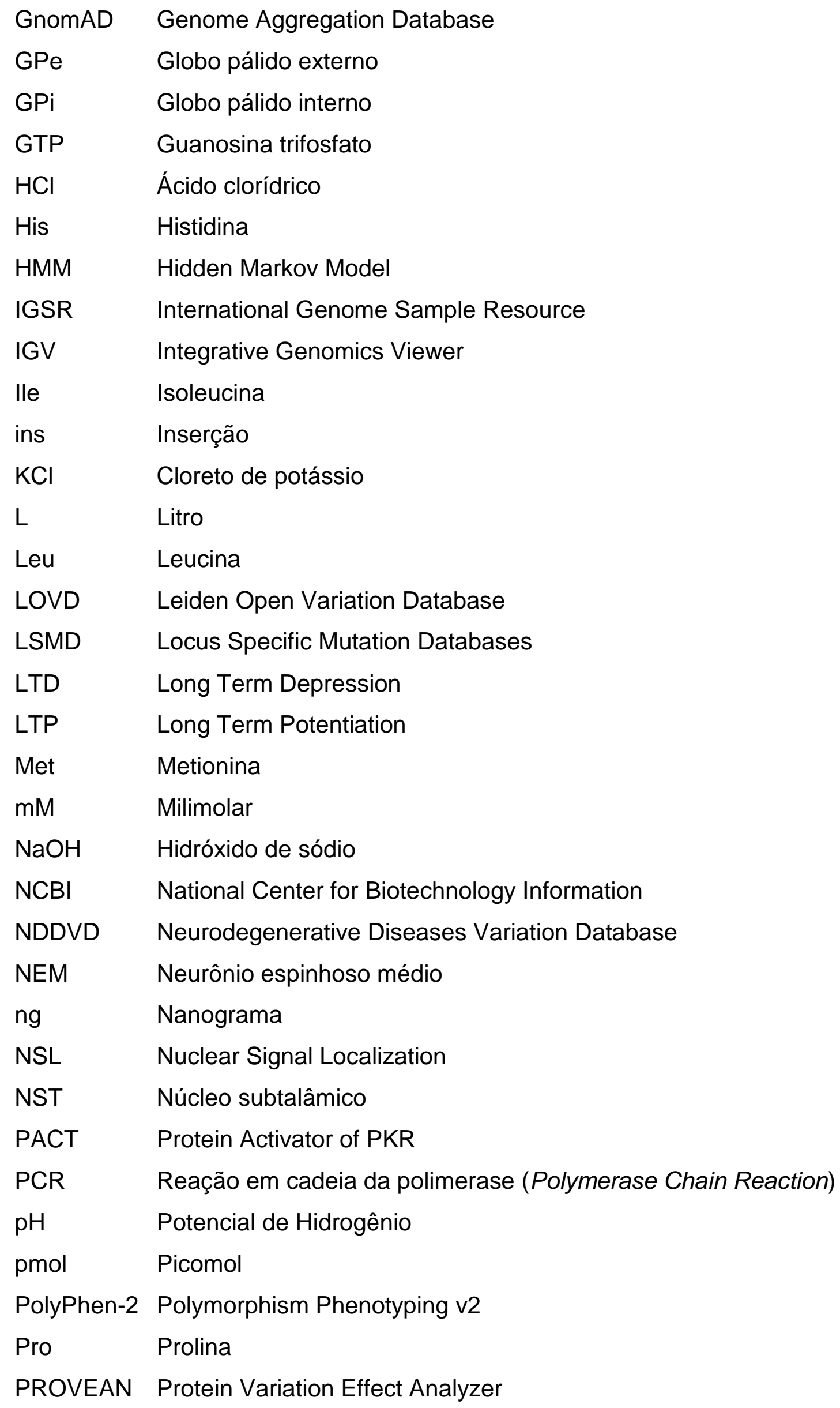




$\begin{array}{ll}\text { RBED } & \text { Rede Brasileira para Estudo das Distonias } \\ \text { RNA } & \text { Ácido ribonucleico } \\ \text { RNAm } & \text { RNA mensageiro } \\ \text { rpm } & \text { Rotações por minuto } \\ \text { Ser } & \text { Serina } \\ \text { SIFT } & \text { Sorting Intolerant From Tolerant } \\ \text { SNpc } & \text { Substância Negra pars compacta } \\ \text { SNpr } & \text { Substância Negra pars reticulata } \\ \text { SUS } & \text { Sistema Único de Saúde } \\ \text { T } & \text { Timina } \\ \text { TCLE } & \text { Termo de consentimento livre e esclarecido } \\ \text { TRBP } & \text { Proteína ligante de RNA responsiva à transativação (TAR RNA Binding } \\ & \text { Protein) } \\ \text { Tris } & \text { Tris-(hidroximetil)-aminometano } \\ \text { Tyr } & \text { Tirosina } \\ \text { U } & \text { Uracila } \\ \text { UTR } & \text { Região não traduzida (Untranslated Region) } \\ \text { Val } & \text { Valina } \\ \end{array}$




\section{Resumo}

Introdução: Distonia é um distúrbio do movimento de ordem neurológica, caracterizado por contrações involuntárias que levam a movimentos e/ou posturas anormais, que podem ocorrer em uma parte isolada ou no corpo todo. Os estudos em distonia têm avançado devido ao aprimoramento das tecnologias de sequenciamento. A descoberta de novos genes e suas variantes alélicas patogênicas vêm possibilitando a identificação de proteínas envolvidas na fisiopatologia das distonias e que comprometem vias metabólicas importantes quando não funcionais. Hoje, o diagnóstico genético em distonia já é um elemento utilizado para definição de prognóstico, auxiliando na indicação de tratamentos específicos, principalmente, em relação ao tratamento cirúrgico, e, na reclassificação de casos esporádicos ou familiares tidos como idiopáticos. Objetivos: Padronizar a análise molecular dos principais genes descritos, identificando variantes potencialmente patogênicas em indivíduos brasileiros com distonia idiopática e caracterizando-as conforme seu grau de patogenicidade para correlações genótipo-fenótipo. Métodos: Através do projeto "Rede Brasileira para Estudo das Distonias", 153 indivíduos com distonia idiopática isolada ou combinada foram investigados para variantes alélicas nos genes TOR1A, TUBB4A, GCH1, TH, DDC, THAP1, SGCE, ATP1A3, PRKRA, CIZ1, ANO3, GNAL e KCTD17 através de um painel de genes customizado TruSeq ${ }^{\circledR}$ Custom Amplicon (Illumina), com sequenciamento no sistema MiSeq (Illumina). As sequências obtidas foram alinhadas ao genoma humano de referência e as variantes alélicas foram caracterizadas por análises in silico quanto ao seu potencial patogênico e correlação com o fenótipo. Modelagem molecular por homologia in silico foi realizada para avaliação do impacto da variante na função e conformação proteica. Resultados: Nesse estudo, em 16\% dos probandos selecionados, identificamos 25 variantes alélicas com possível contribuição causal para distonia na maioria dos genes investigados no painel, incluindo variantes já estabelecidas como causa de distonia nos genes TOR1A, THAP1, GCH1 e PRKRA. Inusitadamente, DYT-PRKRA foi uma causa importante de distonia em nossa amostra, responsável por cerca de $4 \%$ dos casos, sem parkinsonismo. Novas variantes no gene CIZ1, GNAL e KCTD17 correlacionaram com o fenótipo de distonia cervical com surgimento na fase adulta, porém, mioclonia descrita em casos DYT-KCTD17 não foi observada no probando desse estudo. No gene $D D C$, identificamos uma inserção que resulta na alteração na matriz de leitura e 
um códon de parada prematuro com alto impacto na função proteica, segundo análises in silico, em um caso de distonia-parkinsonismo. Conclusões: Através desse estudo, foi possível confirmar o papel dos genes TUBB4A, CIZ1 e KCTD17 como causa de distonia em nossa amostra, sendo esse o primeiro estudo de confirmação em indivíduos brasileiros e, diferente de outros estudos, PRKRA foi uma causa frequente. Além disso, descrevemos 10 novas variantes caracterizadas conforme seu potencial patogênico. Em relação à etiologia da distonia, embora estudos funcionais sejam necessários para confirmar a patogenicidade das variantes identificadas nesse estudo, nossos resultados demonstram causas genéticas entre casos idiopáticos em nossa amostra, com maior eficácia nos casos de início precoce.

Descritores: Distonia/genética; Variação genética; Transtornos dos movimentos 


\section{INTRODUÇÃo}

\subsection{Distonia}

Distonia é um distúrbio do movimento de caráter hipercinético. É caracterizada por contrações musculares, geralmente iniciadas por ação voluntária, que levam a movimentos e/ou posturas de torção anormais, frequentemente repetitivos, que podem ocorrer de forma intermitente ou sustentada e serem acompanhados de tremor. Tais movimentos distônicos afetam diretamente a qualidade de vida dos indivíduos acometidos (conforme a gravidade dos sintomas e os locais afetados), seja por fatores como dor, fadiga, alterações no sono, incapacitação para atividade profissional e até mesmo impedimento da realização de tarefas diárias simples. ${ }^{(1,2)}$

Considerado a princípio um distúrbio psicogênico ${ }^{1}$, distonia passou a ser discutida como um distúrbio do movimento, quando Oppenheim, em 1911, descreveu o quadro clínico de alterações tônico-musculares (alternantes entre hipotonia e hipertonia), sem evidências de atrofia, fraqueza muscular ou perda sensorial. Nos 30 anos seguintes, com a descrição de outros casos, expandiu-se 0 espectro fenotípico da distonia, ora ocorrendo como um sintoma, ora associada à outra doença ou simplesmente ocorrendo como um distúrbio isolado. ${ }^{(3-6)}$

Como nenhum fator causal foi identificado através de análises anatomopatológicas, principalmente quando a distonia ocorria de forma isolada, sua origem psicogênica permaneceu como causa durante anos. Até que em 1942, estudos de eletromiografia se mostraram eficazes em diferenciar distonia de outros distúrbios do movimento, visto que, tal exame possibilita a identificação dos músculos que estão ou não sendo contraídos durante a realização de um determinado movimento. Com base nessa informação, Ernst Herz utilizou-se dessa técnica em indivíduos com distonia isolada, e constatou que tais alterações do tônus muscular (os chamados movimentos distônicos) ocorriam porque músculos agonistas e antagonistas de um movimento contraíam-se simultaneamente. Tal descoberta confirmou distonia como um distúrbio do movimento distinto dos outros, com origens orgânicas e não exclusivamente psicogênicas. ${ }^{(6,7)}$

\footnotetext{
${ }^{1}$ Psicogênico - de origem e desenvolvimento psicológico; causa psíquica que explica uma mudança de comportamento ou revela um sintoma.
} 
A partir de então, para que houvesse um reconhecimento mais amplo dessa condição em diversas populações, tornou-se necessário estabelecer critérios claros de definição e classificação da distonia, os quais se alteraram ao longo dos anos até o último consenso internacional realizado em 2013, no qual foi baseado esse manuscrito. ${ }^{(1)}$

\subsection{Classificação}

A classificação da distonia passou por constantes reformulações, a fim de se adequar ao conhecimento científico atual. Critérios mais definidos e esquemas mais abrangentes foram e continuam sendo propostos, de forma que representem as diversas manifestações clínicas e causas conhecidas. Hoje, distonia é classificada conforme dois eixos principais: características clínicas e etiologia, descritos a seguir. $^{(1,8)}$

Eixo I. Características clínicas: descrevem o grau de acometimento da distonia no indivíduo, sendo elas:

- Idade de início dos sintomas:

- Primeira infância (do nascimento aos 2 anos);

* Segunda infância (dos 3 aos 12 anos);

* Adolescência (dos 13 aos 20 anos);

* Fase adulta inicial (dos 21 aos 40 anos);

* Fase adulta tardia (acima dos 40 anos).

- Distribuição corporal:

* Focal (somente uma região afetada);

* Segmentar (duas ou mais regiões adjacentes afetadas);

* Multifocal (duas ou mais regiões não adjacentes afetadas);

* Hemidistonia (quando a maioria das regiões de um lado do corpo estão afetadas);

* Generalizada (tronco e pelo menos outras duas regiões afetadas).

- Padrão temporal (em relação ao curso da doença):

* Estático (quando não há expansão dos sintomas para outras regiões); 
- Progressivo (quando tende a atingir outras regiões do corpo com o passar do tempo).

- Padrão temporal (em relação à variabilidade de ocorrência):

* Persistente (quando os sintomas persistem ao longo do dia);

* Ação-específica (quando a distonia ocorre mediante a realização de um movimento específico);

* Flutuação-diurna (quando há alteração da gravidade dos sintomas durante o dia);

* Paroxística (após episódios repentinos, desencadeados por um gatilho).

- Eventos associados:

* Distonia isolada (quando distonia é a única característica clínica, com exceção de tremor);

* Distonia combinada (quando ocorre com outro distúrbio do movimento e / ou manifestação sistêmica / neurológica).

Eixo II. Etiologia: descreve a causa e origem do distúrbio, onde cabe destacar se há:

- Mudança anatômica identificável:

* Lesão estrutural ou degeneração.

- Causa genética:

* Autossômica dominante;

* Autossômica recessiva;

* Ligada ao cromossomo X;

* Mitocondrial.

- Causa secundária (evidência de distonia adquirida):

* Injúria cerebral perinatal, infecção, drogas, neoplasia, entre outros.

- Idiopática: onde nenhuma causa etiológica foi identificada. 


\subsection{Diagnóstico}

O diagnóstico consiste, principalmente, em delineamento e avaliação clínica, a partir de uma boa anamnese e exame neurológico. Todavia, distonia é muito heterogênea tanto clínica quanto etiologicamente. Pode iniciar em qualquer faixa etária e região corporal, de forma isolada ou combinada com outros distúrbios e demonstra variados graus de acometimento e incapacitação. (1,8,9)

Exames complementares como eletromiografia, testes laboratoriais e de neuroimagem devem ser considerados em casos duvidosos ou quando há suspeita de distonia por causas secundárias. Testes genéticos são mais úteis nos casos generalizados de início precoce, quando há história familiar positiva (com suspeita de herança genética) ou em casos com fenótipos atípicos (com características clínicas distintas das observadas na rotina médica e que dificultam o diagnóstico clínico), nos quais têm demonstrado maior eficácia em relação a alguns fatores como tempo, custo e precisão diagnóstica. ${ }^{(1,8-10)}$

No Brasil, assim como ocorre com outras doenças raras, o diagnóstico depende da educação e treinamento continuado dos profissionais que atuam na atenção básica à saúde, os quais são responsáveis pelo encaminhamento dos casos suspeitos aos centros de atendimento especializado. Tais centros de atendimento especializado são capazes de realizar o diagnóstico, definir uma estratégica terapêutica, realizar aconselhamento genético, acompanhamento profissional e investigação da causa para melhor definição do prognóstico. ${ }^{(11)}$

Mundialmente, encaminhamento especializado e diagnóstico por vezes é difícil, com demora de meses até anos, sujeito a tratamentos intermediários inadequados. Estudos realizados no Canadá, Estados Unidos e Itália demonstraram que o acesso ao diagnóstico e tratamento da distonia é demorado, principalmente nas formas focais e segmentares de surgimento no adulto. Os indivíduos consultam diversos médicos (em média 3 profissionais, segundo estudo canadense), com uma demora de 1 até 5 anos para o diagnóstico final. ${ }^{(12-14)}$ A variabilidade dos movimentos involuntários, a dependência de experiência e vivência clínica e a própria heterogeneidade da distonia são fatores que dificultam e contribuem para a demora e incerteza no diagnóstico. ${ }^{(8,15)}$ 
Contudo, tal demora entre o surgimento dos sintomas e o diagnóstico tem reduzido nos últimos anos à medida que novos critérios diagnósticos para distonia são discutidos, novos sistemas de definição e classificação são divulgados, profissionais de atenção básica são devidamente treinados e a divulgação da distonia se difunde no meio popular. ${ }^{(8,16)}$

\subsection{Tratamento}

Como ainda não há cura para distonia, o tratamento se baseia no alívio das contrações musculares. Atualmente, é realizado através das seguintes abordagens, ajustadas a cada indivíduo, conforme o local e grau de acometimento dos sintomas: 1. Medicações orais, tais como agentes dopaminérgicos, anticolinérgicos, benzodiazepínicos e relaxantes musculares; 2. Fármacos biológicos injetáveis, como a toxina botulínica; 3. Terapias de reabilitação física ocupacional e 4. Cirurgia de estimulação cerebral profunda (ECP) (ou deep brain stimulation - DBS)..$^{(8,9)}$

No Brasil, a cada dois anos, o Ministério da Saúde divulga recomendações de estratégias terapêuticas para uso no Sistema Único de Saúde (SUS). No geral, após teste inicial com levodopa, devem ser considerados outros tratamentos farmacológicos orais, seguidos pelo uso da toxina botulínica com aplicações intervaladas de 3 a 4 meses, conforme resposta clínica. ${ }^{(15)}$

Mediante casos com diagnóstico caracterizado, tratamentos específicos são realizados levando em consideração a etiologia, o mecanismo de ação e o prognóstico da distonia. ${ }^{(9)}$ Para as formas focais, a toxina botulínica é o tratamento mais utilizado e indicado, mesmo demonstrando efeito temporário e alívio parcial da dor associada às contrações musculares. Para as formas generalizadas, a ECP tem demonstrado melhora significativa dos sintomas, principalmente em distonia isolada, porém, é um procedimento de alto custo e maior risco. ${ }^{(17-19)}$

Outras características, tais como depressão, ansiedade, alterações no sono e fobia social são frequentemente observadas nos indivíduos acometidos e devem ser consideradas na estratégia de tratamento, uma vez que interferem diretamente na qualidade de vida. Elas podem ter relação com vias intrínsecas à fisiopatologia da distonia ou serem secundárias aos fatores como dor, isolamento social e limitação física para realização de atividades diárias. ${ }^{(20,21)}$ 


\subsection{Epidemiologia}

Distonia é considerada uma doença rara. A maioria dos dados epidemiológicos disponíveis são de estudos realizados por centros de atendimento especializado, que têm como base os pacientes acompanhados nesses locais. As abordagens metodológicas desses estudos são variadas e muitas vezes se baseiam especificamente em subgrupos fenotípicos conforme grau de acometimento, fase de início dos sintomas e etiologia. Portanto, estudos epidemiológicos em distonia são parciais e desiguais, em consequência da própria heterogeneidade desse distúrbio. Além disso, o diagnóstico constatado no momento da avaliação pode variar com o passar do tempo após identificação de causas secundárias ou reclassificação para outras patologias. ${ }^{(22-24)}$

Em 2010, após estudo de revisão sistemática, distonia foi reportada como o terceiro distúrbio do movimento mais comum, após tremor essencial e doença de Parkinson, com uma prevalência estimada de 2 a 50 casos por milhão para distonia de início precoce (abaixo dos 20 anos de idade) e de 30 a 7320 casos por milhão para as de início tardio (após os 20 anos de idade). ${ }^{(25)}$ Por outra perspectiva, em 2012, um estudo de metanálise da literatura estimou a prevalência global de 16,43 casos a cada 100.000 habitantes para distonia primária (sem causa adquirida). ${ }^{(26)}$

No geral, há constatações uniformes entre os estudos realizados, tais como: - Distonia focal de surgimento no adulto é a forma mais frequente, principalmente com acometimento cervical ou como blefaroespasmo (prevalência de 27 a 600 casos por milhão); - Mulheres possuem mais chances de serem afetadas nas formas focais, com exceção da cãibra do escrivão que é mais frequente em homens; História familiar positiva é observada em cerca de $20 \%$ dos casos; e aproximadamente $70 \%$ dos casos de distonia isolada são idiopáticos. ${ }^{(22,24,35,27-34)}$

A maioria dos estudos epidemiológicos foram realizados em países europeus. Recentemente, no Brasil, foi estimada uma prevalência de 19,8 casos a cada 100.000 habitantes para distonia primária (sem causa secundária), considerando a população da cidade de Ribeirão Preto, São Paulo. ${ }^{(35)}$ Não há boletins epidemiológicos disponíveis na plataforma do Ministério da Saúde (consulta realizada em 10/05/2019 em: portalms.saude.gov.br/boletins-epidemiologicos) e o sistema 
TABNET (DATASUS) ${ }^{2}$ não indica dados de morbidade hospitalar do SUS específicos para distonia (consulta realizada em 10/05/2019).

\subsection{Fisiopatologia}

Para a realização de um movimento voluntário, é necessário que ocorra a contração do músculo agonista (responsável pela realização do movimento) e relaxamento do músculo antagonista (que se opõe ao movimento selecionado). sistema motor determina e controla os impulsos necessários para a produção do movimento ou postura e quanto mais sincronizado e aperfeiçoado esse processo de contração e relaxamento, mais eficaz será o movimento. Tal abordagem ocorre para movimentos que exercem tanto a função de contração quanto sustentação e estabilização muscular, associados a parâmetros específicos como velocidade, tempo, força e distância conforme percepção espacial e sensorial.

Movimentos distônicos resultam da perda desse sincronismo motor, desencadeando a contração simultânea e desordenada de músculos agonistas e antagonistas do movimento requerido, gerando assim um movimento ou uma postura de torção. Essa foi uma das primeiras evidências que fundamentaram a hipótese de que distonia resulta de perturbações no sistema neurológico motor, a partir de alterações na circuitaria motora cinética (que seleciona impulsos para realização do movimento) em relação à circuitaria motora estática (que seleciona impulsos necessários para estabilizar o movimento). Tais alterações estariam relacionadas à estruturas e vias neurais especificamente comprometidas (seja por danos estruturais ou moleculares), somadas à alterações no processo de iniciativa motora (considerando que movimentos voluntários dependem de estímulos internos e externos) ou na integração sensório-motora (conforme interação do corpo com o meio no qual está inserido)..$^{(6,7)}$

\footnotetext{
${ }^{2}$ Disponível em: http://www2.datasus.gov.br/DATASUS/index.php?area=0203
} 


\subsection{Estruturas anatômicas envolvidas}

Anatomicamente, o sistema neurológico motor é composto por diversas estruturas, como o córtex, os núcleos da base, o cerebelo, o hipocampo e o tálamo. Essas estruturas trabalham em conjunto, interagindo entre si, a fim de manter o controle postural, planejar, controlar e executar movimentos específicos, além de aprender novas vias motoras durante o desenvolvimento. ${ }^{(36,37)}$

Distonia é o principal distúrbio do movimento resultante de lesões no globo pálido e putâmen, o que inicialmente evidenciou o papel dos núcleos da base em sua fisiopatologia. ${ }^{(38)}$

Os núcleos da base são estruturas subcorticais, organizadas somatotopicamente com áreas do córtex. Possuem estruturas de entrada, de processamento e de saída de estímulos, caracterizadas conforme os neurotransmissores envolvidos. Por meio de circuitos de comunicação extremamente coordenados, estabelecidos com áreas motoras do córtex e o tálamo, os núcleos da base são responsáveis por modular e ajustar o movimento iniciado, selecionando os comandos necessários enquanto inibe movimentos contrários. Ademais, possui outros circuitos em conjunto com o núcleo acumbens, o hipocampo e o lobo límbico, implicados nos processos de aprendizado motor e associação de movimentos às vias emocionais. ${ }^{(36,37,39,40)}$ Os núcleos da base são divididos em: estriado, globo pálido, núcleo subtalâmico e substância negra (SN).

O estriado, constituído pelo núcleo caudado e pelo putâmen, é a maior e principal estrutura de entrada dos núcleos da base. Sua porção dorsal está relacionada com áreas do córtex motor e pré-motor estabelecendo a circuitaria motora, enquanto suas porções ventral e medial estão relacionadas com áreas do córtex cingulado, orbitofrontal e pré-frontal constituindo os circuitos límbico e associativo. Em sua maioria, é composto por neurônios de projeção caracterizados por dendritos espinhosos e axônios longos (também descritos como neurônios espinhosos médios NEMs), e em minoria, por interneurônios que possuem axônios menores e dendritos sem espinhos. O globo pálido processa as informações recebidas do estriado. É dividido em globo pálido interno (GPi), que inibe diretamente a atividade talâmica, e globo pálido externo (GPe) que inibe tonicamente o núcleo subtalâmico (NST), que por sua vez, regula a atividade do GPi. A SN, dividida em pars compacta e pars reticulata, 
atua, entre outras funções, na modulação da atividade estriatal, além de também ser uma estrutura de saída inibitória ao tálamo (Figura 1). ${ }^{(36,40-42)}$

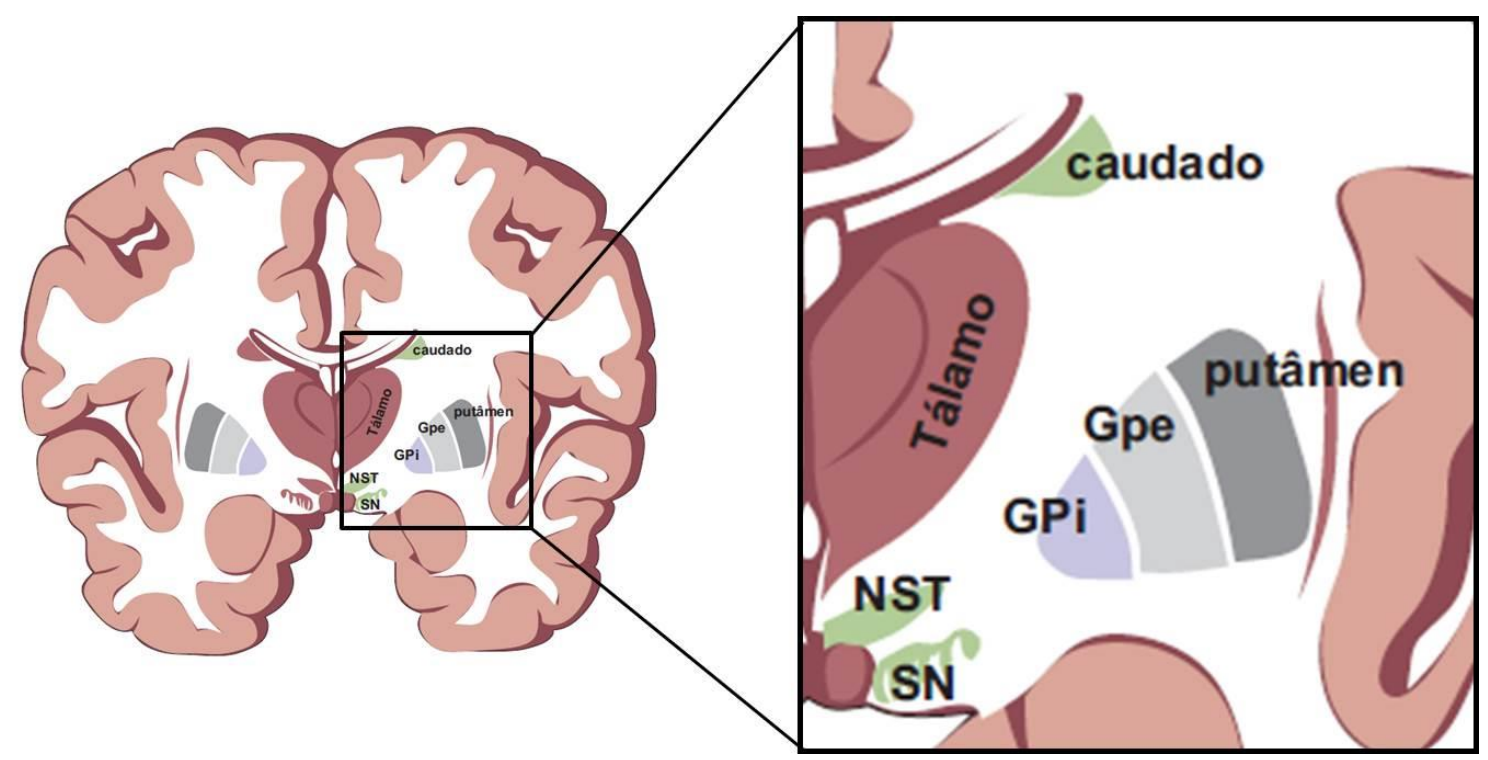

Corte coronal do cérebro demonstrando os núcleos da base, divididos em: estriado (composto pelo núcleo caudado e pelo putâmen), globo pálido (divido em globo pálido externo - GPe e globo pálido interno - GPi), núcleo subtalâmico (NST) e substância negra (SN).

Fonte: Bear MF, Connors BW, Paradiso MA. Neurociências: desvendando o sistema nervoso. 3a ed. Traduzido por Carla Dalmaz. Porto Alegre: Artmed; 2008. Cap. 14. Controle encefálico do movimento p.452-78. Figura 14.11 Os núcleos da base e estruturas associadas; p.465.

Figura 1. Núcleos da base

Além dos núcleos da base, o envolvimento de outras estruturas neurais tem sido descrito. Modelos animais, farmacológicos e genéticos, juntamente com dados experimentais em humanos, indicam a contribuição do tálamo, do córtex e do cerebelo na fisiopatologia da distonia, uma vez que, tais estruturas possuem funções neurológicas independentes mas também complementam o sistema motor. $^{(43,44)}$

O tálamo é uma central de mecanismos sensoriais, motores e cognitivos. Possui diversos núcleos que recebem estímulos provenientes do córtex, da $\mathrm{SN}$, do globo pálido, do cerebelo e de vias sensoriais periféricas e núcleos que enviam estímulos de volta ao córtex e ao estriado. ${ }^{(41)}$

Em relação ao cerebelo, estudos recentes têm indicado que lesões nessa estrutura e alterações na atuação das células de Purkinje resultam em movimentos distônicos topograficamente relacionados com as regiões afetadas, onde alterações no vérmis (região central do cerebelo) estariam relacionadas com manifestação dos sintomas no tronco corporal, enquanto alterações nos hemisférios cerebelares estariam relacionadas com manifestação dos sintomas nos membros. ${ }^{(45,46)}$ 


\subsection{Circuitaria motora}

A circuitaria motora envolvida na realização de movimentos voluntários ocorre por meio de circuitos e vias de sinalização, na qual a informação recebida pelo córtex é transmitida aos núcleos da base, desses ao tálamo, do tálamo de volta para o córtex e desse para diversos componentes do sistema nervoso central e periférico. Tais circuitos motores são estabelecidos por meio de estímulos excitatórios, inibitórios e estímulos moduladores dependentes de receptores específicos, que se moldam e se adaptam conforme as particularidades comportamentais do indivíduo (Figura 2). A interação entre esses circuitos aumenta ou diminui a atividade do tálamo sobre áreas corticais, por meio de uma via direta que busca permitir a realização do movimento desejado e uma via indireta que inibe movimentos contrários. ${ }^{(36,37,47)}$

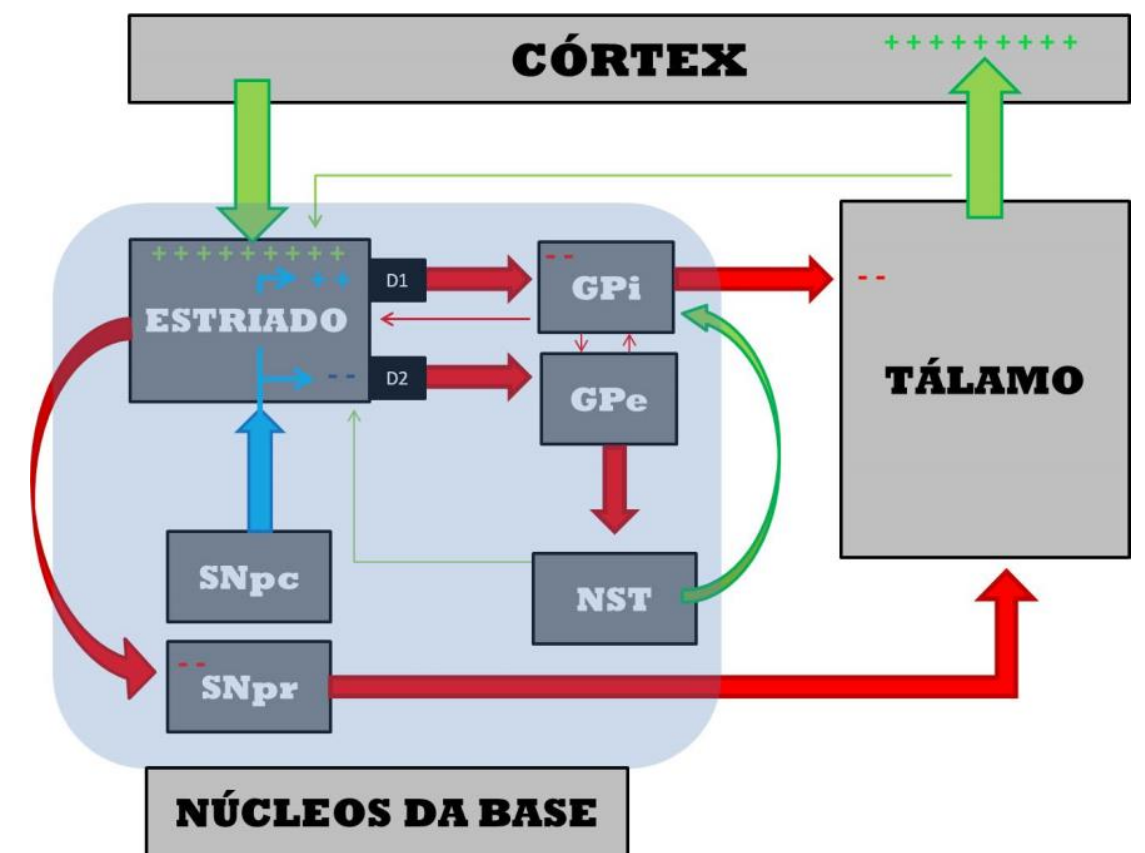

A circuitaria motora ocorre por meio de circuitos neurais estabelecidos entre o córtex, os núcleos da base e o tálamo. Essas estruturas interagem entre si por meio de estímulos excitatórios (seta verde, +), estímulos inibitórios (seta vermelha, -) e estímulos dependentes de receptores específicos (seta azul, + ou -). GPi: globo pálido interno. GPe: globo pálido externo. SNpc: substância negra pars compacta. SNpr: substância negra pars reticulata. NST: núcleo subtalâmico. D1 e D2: receptores de dopamina do tipo D1 e D2. Os sinais de mais (+) e menos (-) indicam efeito excitatório ou inibitório, respectivamente.

Figura 2. Circuito córtex - núcleos da base - tálamo

Tanto na via direta quanto na indireta, mediante intenção de realizar um movimento (determinado pelo processo de iniciativa motora), regiões específicas do 
córtex motor e pré-motor enviam sinais excitatórios ao estriado, o qual também é influenciado pela SN. Para as regiões que devem ser ativadas, onde o movimento é necessário, a via direta é mais ativa. Nessa via, o estriado inibe o GPi e a SNpr, reduzindo a inibição tônica que esses núcleos exercem sobre o tálamo. Uma vez desinibido, o tálamo fica livre para enviar sinais excitatórios de volta ao córtex. Essa via é classificada como "facilitadora do movimento" porque reduz a força inibitória exercida sobre o tálamo (Figura 3). ${ }^{(36,37)}$

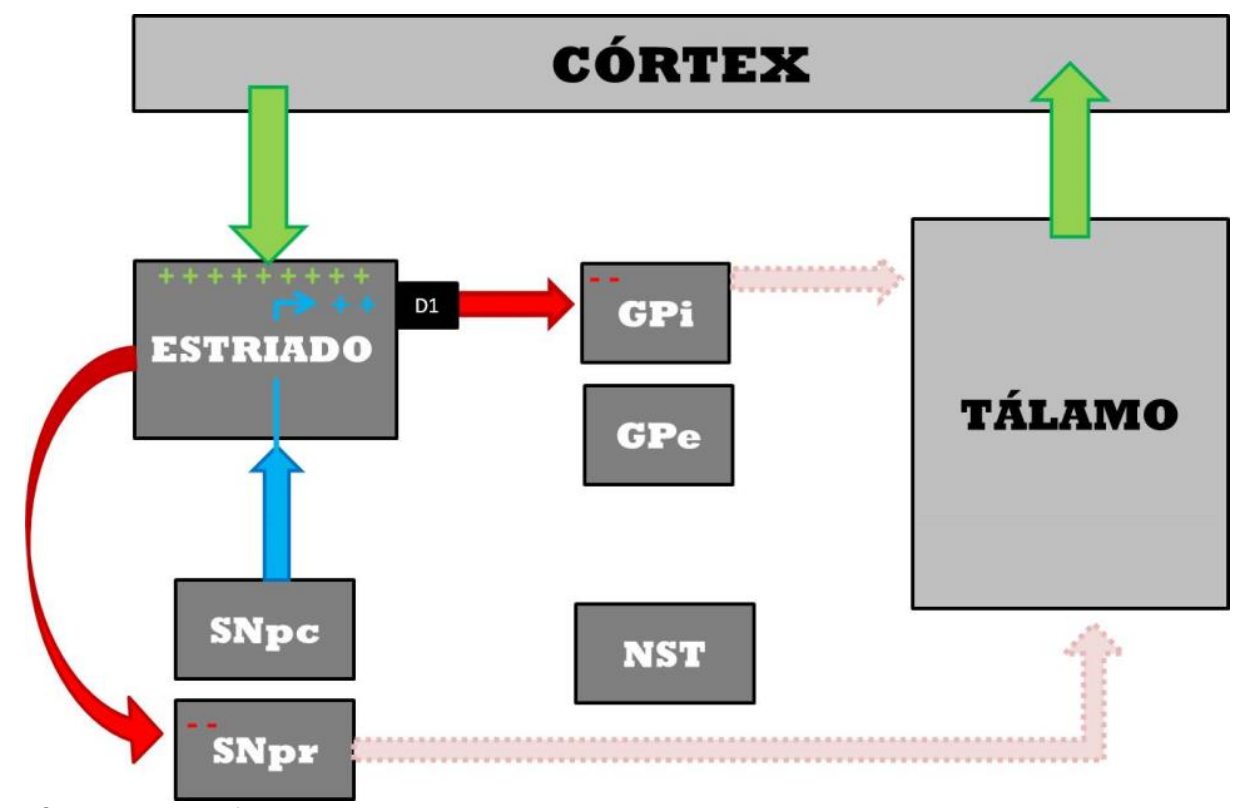

A via direta é uma via facilitadora do movimento, na qual, o estriado recebe sinais excitatórios glutamatérgicos do córtex (seta verde, +) e envia sinais inibitórios gabaérgicos ao globo pálido interno (GPi) e à substância negra pars reticulata (SNpr) (seta vermelha, -), que por sua vez, deixam de inibir tonicamente o tálamo (seta rosa), deixando-o livre para enviar sinais excitatórios ao córtex. Através dos receptores de dopamina do tipo D1, a dopamina proveniente da substância negra pars compacta (SNpc) aumenta o potencial excitatório glutamatérgico dos neurônios dessa via (seta azul, +). NST: Núcleo subtalâmico.

Figura 3. Via direta do movimento

Porém, como citado anteriormente, para um movimento eficiente é necessário que ocorram processos inibitórios, de forma a evitar movimentos contrários ao movimento iniciado. Para tal, na via indireta do movimento, o estriado inibe o globo pálido externo, que por sua vez, deixa de inibir o NST. Desinibido, o NST envia sinais excitatórios ao $\mathrm{GPi}$, o que permite que ele volte a inibir o tálamo, impedindo-o de ativar as regiões do córtex responsáveis por movimentos contrários ao iniciado. Essa via reduz o movimento porque potencializa a ação inibitória do GPi sobre o tálamo (Figura $4) .{ }^{(36,37)}$ 
Além das vias direta e indireta, há também a descrição de uma via hiperdireta. Nessa via, o córtex envia sinais excitatórios glutamatérgicos diretamente ao NST, sem passar pelo estriado, de forma a potencializar a via indireta e aumentar os sinais inibitórios do GPi direcionados ao tálamo. Com menor tempo de condução dos estímulos, essa via está relacionada à uma resposta mais rápida, em ações que buscam brevemente ajustar e equilibrar o planejamento motor. Para constar, há também circuitos diretos de retroalimentação e controle, estabelecidos interna e externamente aos núcleos da base, como conexões tálamo estriatais, estriado-palidais, estriado-subtalâmicas e entre os segmentos interno e externo do globo pálido (Figura 2). ${ }^{(40,48)}$

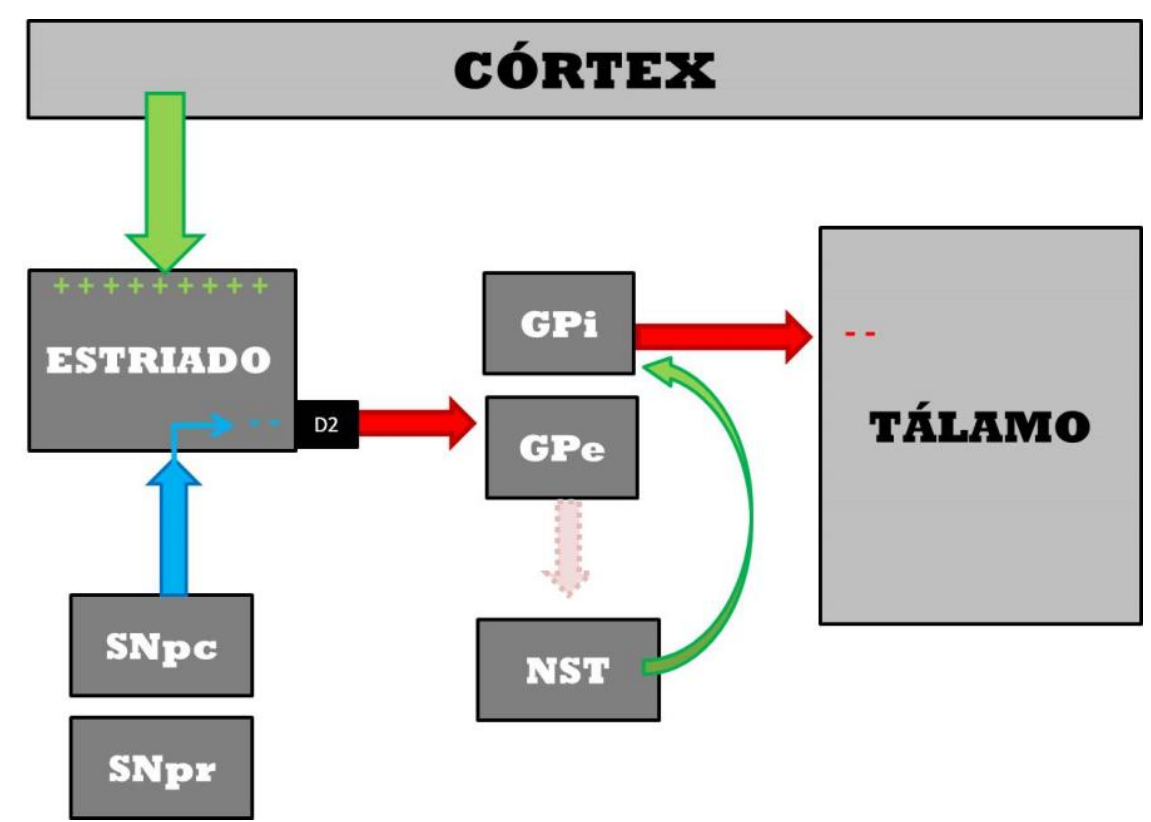

A via indireta atua de forma a reduzir o movimento, na qual, o estriado recebe estímulos excitatórios glutamatérgicos do córtex (seta verde, +) e envia sinais inibitórios ao globo pálido externo $(\mathrm{GPe})$ (seta vermelha). Uma vez inibido, o GPe deixa de inibir o núcleo subtalâmico (NST) (seta rosa), deixando-o livre para enviar sinais excitatórios ao globo pálido interno (GPi) para que o tálamo volte a ser inibido. A dopamina proveniente da substância negra pars compacta (SNpc) inibe os neurônios dessa via, via receptores D2, reduzindo ou retardando o potencial excitatório glutamatérgicos nos neurônios estriatais.

Figura 4. Via indireta do movimento

Como o estriado é a principal estrutura de entrada dos núcleos da base, sua arquitetura sináptica é variada e complexa. Os neurônios estriatais de projeção (ou neurônios espinhosos médios), são excitados via sinapses corticais glutamatérgicas, realizadas na ponta dos seus espinhos dendríticos distais. O efeito glutamatérgico excitatório nesses neurônios é potencializado ou atenuado por estímulos dopaminérgicos provenientes da SNpc (os quais ocorrem nas laterais dos mesmos espinhos dendríticos), ou, por estímulos gabaérgicos e colinérgicos 
provenientes dos interneurônios estriatais (que ocorrem nos dendritos proximais ou corpo celular) (Figura 5). Como parte do sistema de retroalimentação, o estriado também recebe aferências glutamatérgicas do NST e do tálamo, e gabaérgicas do globo pálido. ${ }^{(40,49)}$

A SN atua nesse circuito de forma moduladora, uma vez que a ação da dopamina no estriado é dependente dos tipos de receptores expressos nos neurônios estriatais. Os neurônios constituintes da via direta expressam receptores de dopamina do tipo D1, que quando ativados desencadeiam efeito excitatório nesses neurônios, liberando ácido gama-aminobutírico (GABA) e substância P / dinorfina como neurotransmissores, inibindo assim os neurônios do GPi e facilitando o movimento. Por outro lado, os neurônios estriatais constituintes da via indireta expressam receptores de dopamina do tipo D2, que desencadeiam efeito inibitório nesses neurônios, os impedindo de liberar seus neurotransmissores GABA e encefalina (Figura 5). Essa ação reduz a atuação da via indireta, mantendo a ativação inibitória tônica do GPe sobre o NST, o impedindo de estimular o GPi, portanto, facilitando o movimento. ${ }^{(40,49,50)}$

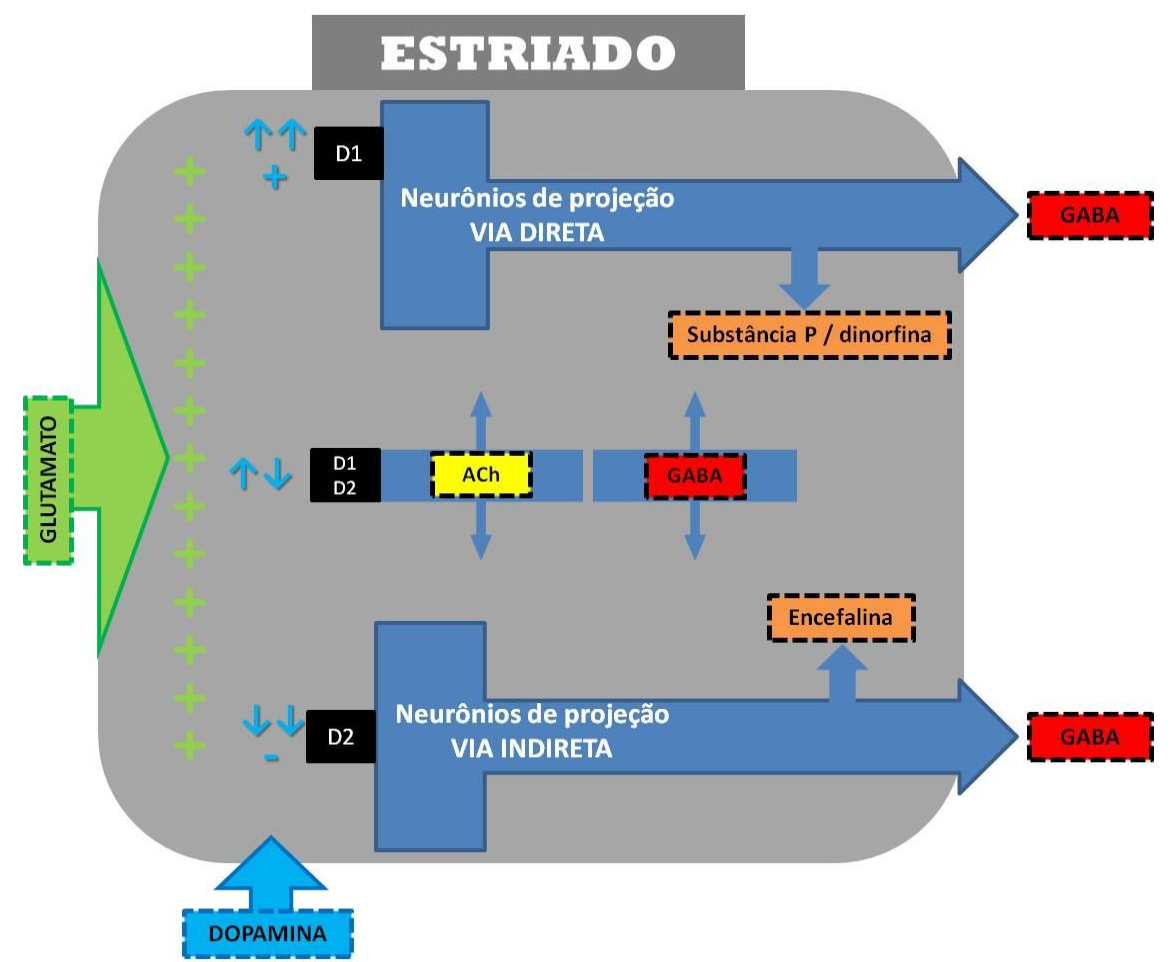

A dopamina atua nos neurônios espinhosos médios potencializando o efeito excitatório glutamatérgico recebido do córtex e facilitando o movimento, uma vez que estimula a via direta (liberação de ácido gama-aminobutírico (GABA) e de substância P/ dinorfina) e inibe a via indireta (liberação de GABA e de encefalina). Além disso, a dopamina também regula a atividade dos interneurônios, controlando a liberação de acetilcolina (Ach) e GABA de ação local. Estímulo glutamatérgicos excitatório (seta verde, +). Estímulo dopaminérgico dependente de receptor específico (seta azul, + ou -). Receptores de dopamina (D1 e D2).

Figura 5. Microcircuitaria estriatal 
Os interneurônios estriatais, que também são influenciados pela dopamina proveniente da SNpc e pelos neuropeptídeos (como a substância P, dinorfina e encefalina) liberados pelos neurônios de projeção, também regulam a atividade de toda a microcircuitaria estriatal. Além de interneurônios gabaérgicos inibitórios, os interneurônios colinérgicos desencadeiam ações distintas, mediadas por receptores específicos. Os receptores muscarínicos desencadeiam resposta excitatória ou inibitória via cascata de segundos mensageiros (a depender do subtipo de receptor expresso), e os receptores nicotínicos, como canais iônicos, desencadeiam uma resposta excitatória mais rápida. Essa atuação pode ocorrer nos neurônios de projeção ou entre os próprios interneurônios estriatais, controlando o potencial excitatório e gerenciando sistemas de retroalimentação e neuromodulação pré e póssinápticos. ${ }^{(40,49-51)}$

Como uma hipercinesia, postulou-se inicialmente que distonia ocorre devido a um desequilíbrio nas vias motoras, com superestimulação da via direta e deficiência da via indireta. ${ }^{(36,52,53)}$ Porém, somente essa hipótese não explica esse distúrbio em sua totalidade, principalmente em relação à sua heterogeneidade clínica e etiológica e às alterações observadas em outras estruturas do sistema motor, além dos núcleos da base. ${ }^{(44)}$

Foi com base nessas informações, que distonia passou a ser hipotetizada como um distúrbio em rede, com papel central, mas não exclusivo dos núcleos da base, onde o nível e a localização da lesão estão relacionados com a heterogeneidade observada. Os principais mecanismos fisiopatológicos propostos envolvem além da perda de inibição, alterações na integração sensório-motora, desequilíbrio dopaminérgico e desarranjo de plasticidade. ${ }^{(43,44,46,54-56)}$

A perda de inibição se caracteriza pela baixa ativação da via indireta, ou seja, pela deficiência da circuitaria motora em inibir o tálamo, permitindo que ele envie estímulos excitatórios excessivos ao córtex, resultando em ativação muscular exacerbada. Há diversas evidências e submecanismos que se relacionam à perda de inibição em distonia, tais como hiperativação cortical, cerebelar e estriatal durante execução motora e hipoativação do GPi (restaurada após estimulação cerebral profunda) (Figura 6). ${ }^{(16,37,53)}$ 


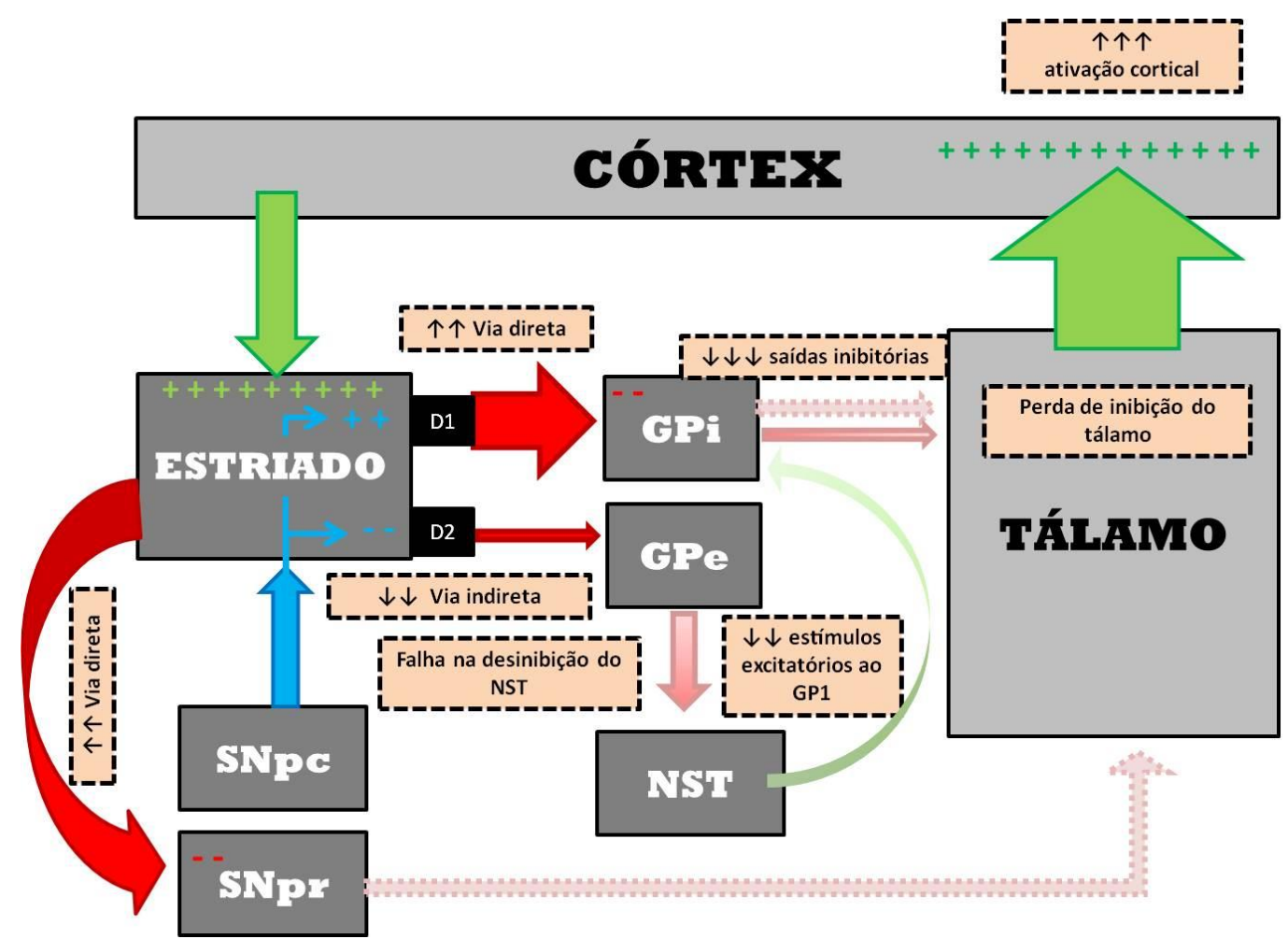

No mecanismo de perda de inibição há uma superativação da via direta, inibindo excessivamente o globo pálido interno (GPi) e a substância negra pars reticulata (SNpr), resultando em uma maior diminuição de saídas inibitórias desses núcleos ao tálamo. Por outro lado, a baixa ativação da via indireta leva à falha de inibição do globo pálido externo (GPe), que por sua vez, continua inibindo em parte o núcleo subtalâmico (NST). A falha no processo de desinibição do NST, reduz seus estímulos excitatórios direcionados ao $\mathrm{GPi}$, reduzindo mais as saídas inibitórias desse núcleo ao tálamo. $\mathrm{O}$ comprometimento da inibição talâmica resulta no aumento de estímulos excitatórios enviados ao córtex.

Figura 6. Mecanismo fisiopatológico de perda de inibição em distonia

O mecanismo de disfunção na integração sensório-motora está relacionado com alterações nas regiões somatotópicas do córtex somatossensorial, descritas principalmente em indivíduos com distonia focal e tarefa-específica. ${ }^{(44,57)}$ Essas alterações causam um déficit na interpretação e no processamento dos estímulos sensoriais recebidos e na discriminação espacial e temporal, resultando em respostas motoras inadequadas. ${ }^{(53)}$

Alterações no processo de adaptação ou plasticidade sináptica também foram demonstradas em indivíduos com distonia, o que explica, em parte, a melhora clínica dos sintomas após meses da cirurgia de estimulação cerebral profunda, com resposta correspondente à via comprometida. ${ }^{(58-60)}$ Como a circuitaria motora se desenvolve ao longo da vida (de acordo com o aprendizado adquirido, praticado e as influências ambientais), as vias motoras se alteram ao longo do desenvolvimento, com diversos circuitos sendo construídos ou inativados, conforme as necessidades intrínsecas do indivíduo e durante mudanças no plano corporal e espacial durante 0 crescimento. ${ }^{(37)}$ 
Dentre os núcleos da base, o estriado é a estrutura que apresenta maior plasticidade devido aos processos de aprendizado e memorização de comandos motores. Mecanismos relacionados à plasticidade, como potenciação de longa duração (LTP - Long Term Potentiation) e depressão de longa duração (LTD - Long Term Depression), são capazes de promover mudanças funcionais nos circuitos neurais (seja através da quantidade de receptores disponíveis, na extensão e disposição espacial de ramificações ou na densidade de espinhos dendríticos), aumentando a força sináptica ou deletando comunicações sinápticas entre neurônios, mediante uso contínuo ou desuso de um comando motor. Essa alteração de plasticidade tem sido observada em modelos animais genéticos de distonia (DYT-TOR1A/DYT1). Nesses modelos, há um aumento de LTP e diminuição de LTD nas projeções córtico-estriatais, o que indica falha em reverter padrões motores inadequados, afetando o processo de aprendizagem e adaptação motora. ${ }^{(41,53,60)}$

Ademais, no mesmo modelo genético também foi demonstrado um aumento da atividade colinérgica no estriado, associada à uma redução de receptores de dopamina D2. Apesar de não estar claro se essas observações são causa ou consequência da distonia, a redução na disponibilidade dos receptores D2 de dopamina afeta a inibição que o estriado exerce sobre o globo pálido, assim como, a capacidade de LTD, ao mesmo tempo que altos níveis de acetilcolina estariam aumentando o processo de LTP, fortalecendo comportamentos motores anormais, incapazes de serem inativados. A melhora dos sintomas após administração de anticolinérgicos em alguns casos pode ser explicada em parte por um processo de LTD restaurado, capaz de melhorar o déficit inibitório. ${ }^{(37,41,61)}$

E por fim, a complexidade da distonia, suas particularidades sintomáticas e toda a circuitaria de modulação motora envolvida (a qual não está compreendida em sua totalidade), refletem a dificuldade em elucidar a patogênese desse distúrbio. Até hoje, a multivariedade clínica e etiológica da distonia dificulta a estratificação amostral e os estudos fisiopatológicos. ${ }^{(62)}$

\subsection{Genética}

Desde a descrição da distonia, em 1911, casos familiares já haviam sido reportados, revelando a natureza hereditária dessa condição. ${ }^{(5)}$ Atualmente, 
história familiar positiva de distonia é observada em aproximadamente $20 \%$ dos casos. $^{(34)}$

Nos últimos anos, com uma maior acessibilidade às tecnologias de sequenciamento de nova geração, a investigação de casos hereditários está levando à descoberta de novos genes e mecanismos moleculares envolvidos nos processos fisiopatológicos da distonia. Além disso, as causas genéticas têm demonstrado o envolvimento de diversas estruturas e circuitos neuronais, relacionados com os locais de expressão da proteína alterada e vias metabólicas comprometidas..$^{(1,16,63,64)}$ A atuação dessas proteínas é variada e complexa, com diversos mecanismos neuronais envolvidos, tais como transdução de sinal, transporte celular, dinâmica citoesquelética, regulação de transcrição, tradução e síntese proteica, síntese de neurotransmissores, homeostase do retículo endoplasmático e resposta ao estresse celular. ${ }^{(9,53,63)}$

Hoje, há mais de vinte loci identificados para as formas hereditárias de distonia, com mais de dez genes confirmados. Entre as principais causas, variantes genéticas nos genes TOR1A, ${ }^{(65)}$ TUBB4A, ${ }^{(66)}$ THAP1 ${ }^{(67)} \mathrm{ClZ1}{ }^{(68)}{ }^{(6)}{ }^{\left(63^{(69)}\right.}$ e GNAL ${ }^{(70)}$ foram reportadas para distonia isolada. Para distonia combinada com parkinsonismo foram reportadas variantes nos genes $G C H 1,{ }^{(71)} T H^{(72)} A T P 1 A 3^{(73)}$ e $P R K R A^{(74)}$ e, para distonia combinada com mioclonia, variantes nos genes $S G C E^{(75)}$ e $K_{C T D 17^{(76)}}$ (Quadro 1). O gene $D D C$ não é classificado diretamente como uma causa de distonia, está relacionado com um quadro mais grave e pode abranger, além da distonia, outras disfunções neurológicas causadas pela deficiência de catecolaminas no sistema nervoso. ${ }^{(77)}$

Quadro 1. Principais genes confirmados para distonia

\section{DISTONIA ISOLADA}

DYT-TOR1A ${ }^{(65)}$

DYT-TUBB4 $4^{(66)}$

DYT-THAP1 ${ }^{(67)}$

DYT-CIZ1 ${ }^{(68)}$

DYT-ANO3 $3^{(69)}$

DYT-GNAL ${ }^{(70)}$

DISTONIA - PARKINSONISMO

DYT-GCH1 $1^{(71)}$

DYT-TH ${ }^{(72)}$

$\mathrm{DDC}^{(77)}$

DYT-ATP1A3 $3^{(73)}$
$A D$

$A D$

$A D$

$A D$

$A D$

$A D$

$A D$

AR

AR

$A D$

\section{Padrão de herança Lócus}

\section{Fenótipo predominante}

DYT1 Generalizada de surgimento precoce

DYT4 Crânio-cervical com disfonia espasmódica

DYT6 Generalizada de surgimento na adolescência

DYT23 Crânio-cervical de surgimento tardio

DYT24 Crânio-cervical de surgimento tardio

DYT25 Crânio-cervical de surgimento tardio

DYT5a Distonia dopa-responsiva

DYT5b Distonia dopa-responsiva

Distonia-parkinsonismo*

DYT12 Distonia-parkinsonismo de surgimento repentino 
..continuação

\begin{tabular}{|c|c|c|c|}
\hline \multirow{3}{*}{\multicolumn{2}{|c|}{$\begin{array}{l}\text { DYT-PRKRA } \\
\text { DISTONIA - MIOCLONIA }\end{array}$}} & DYT16 & Distonia-parkinsonismo precoce \\
\hline & & & \\
\hline & $A D$ & DYT11 & Distonia-mioclonia \\
\hline DYT-KCTD17(76) & $A D$ & DYT26 & Distonia-mioclonia de surgimento na infância \\
\hline
\end{tabular}

\subsubsection{DYT-TOR1A (DYT1)}

O gene TOR1A, no cromossomo 9q, foi relacionado ao lócus DYT1 em 1997 como uma causa de distonia autossômica dominante, com casos já descritos na população brasileira. ${ }^{(65,78,79)}$ Embora o fenótipo observado na maioria dos casos seja de distonia com surgimento focal precoce e posterior generalização, variabilidade fenotípica tem sido descrita, inclusive entre casos com a mesma variante genética. Além disso, os sintomas se manifestam em aproximadamente $30 \%$ dos afetados, devido à penetrância reduzida e até mesmo devido a polimorfismos de susceptibilidade ou proteção. ${ }^{(80-83)}$

A proteína torsina 1A (codificada por TOR1A) é expressa em diversos tecidos. No sistema nervoso central, torsina $1 \mathrm{~A}$ possui seus maiores níveis de expressão no córtex, no hipocampo, no cerebelo e, principalmente, nos neurônios dopaminérgicos da SNpc. ${ }^{84)}$ É localizada em vários compartimentos intracelulares como o retículo endoplasmático, membrana nuclear, cones de crescimento neuronal e vesículas sinápticas. ${ }^{(85-87)}$

Como uma ATPase, torsina A atua em diversos processos celulares, tais como: controle, processamento, estabilidade e localização de proteínas, redução de proteínas deformadas, reciclagem de vesículas sinápticas, integridade do envelope nuclear, interação com proteínas citoesqueléticas (relacionada à ligação do envelope nuclear ao citoesqueleto, importante para polaridade nuclear), tráfego celular e direcionamento de proteínas de membrana (regulando a localização de transportadores, receptores e outras proteínas expressas na superfície celular). ${ }^{(87-91)}$

Torsina $1 \mathrm{~A}$ possui 332 aminoácidos. Os primeiros 40 resíduos são hidrofóbicos, dos quais 20 constituem uma sequência sinalizadora que é clivada no processo de maturação. Após esse processo, torsina $1 \mathrm{~A}$ se mantém associada perifericamente ao lúmen do retículo endoplasmático, com sua porção $\mathrm{N}$-terminal restante ligada à membrana e sua porção C-terminal (onde está o domínio AAA+ ATPase) no lúmen. ${ }^{(86,92)}$ Também possui regiões de interação com as proteínas 
SNAPIN ${ }^{(89)}$ (processo de reciclagem de vesículas sinápticas), $\mathrm{KLC1}^{(93)}$ (chaperona da proteína cinesina) e SYNE3 ${ }^{(91)}$ (ligação do envelope nuclear ao citoesqueleto), dois motivos Walker (de interação com íons magnésio e ATP), sítios ligantes de ATP, sítios de glicosilação e sítios de alteração conformacional mediante ligação de ATP. ${ }^{(94,95)}$

O papel exato dessa proteína na fisiopatologia da distonia ainda não foi elucidado. Estudos funcionais e modelos animais indicam o comprometimento de diversos processos neuronais, como a endocitose de vesículas sinápticas, ${ }^{(89)} 0$ funcionamento do envelope nuclear em relação ao citoesqueleto ${ }^{(91)}$ e formação de inclusões perinucleares. ${ }^{(96)}$

Além disso, em comparação com controles, indivíduos assintomáticos demonstraram déficit no aprendizado de sequências, necessitando de uma maior ativação do córtex para controlar o movimento durante o processo de aprendizado. ${ }^{(97)}$ Modelo animal DYT-TOR1A resulta em distonia, onde foram observadas alterações na atividade estriatal, defeitos na liberação de dopamina e perturbação de vias cerebelares e hipocampais. Tal modelo exemplifica a hipótese de alterações em rede que resultam em distonia generalizada de início precoce. ${ }^{(44,61)}$

Tratamento cirúrgico de estimulação cerebral profunda tem demonstrado melhora dos sintomas. ${ }^{(98)}$

\subsubsection{DYT-TUBB4A (DYT4)}

O gene TUBB4A (cromossomo 19p) foi descrito como uma causa genética rara de distonia, relacionada ao lócus DYT4, em indivíduos da Austrália e GrãBretanha que portavam a variante $c .4 C>G$ (p.Arg2Gly), em padrão autossômico dominante. $O$ fenótipo predominantemente observado foi surgimento tardio de "disfonia sussurrante", resultante de distonia laríngea, associada à distonia crânio-cervical, segmentar ou generalizada. ${ }^{(66)}$

TUBB4A codifica a proteína $\beta$-tubulina 4A que atua como GTPase na constituição dos microtúbulos, com marcante expressão no cerebelo e putâmen. Variantes nesse mesmo gene também estão descritas como causa de um tipo de leucodistrofia, com hipomielinização e atrofia dos gânglios da base e cerebelo, com fenótipo muito amplo que inclui, além de distonia, diversas outras alterações motoras e cognitivas de início precoce. ${ }^{(99-101)}$ 
Estudos funcionais demonstraram que diferentes variantes no TUBB4A afetam distintamente a dinâmica dos microtúbulos. As variantes descritas para leucodistrofia com hipomielinização resultam em alterações nos oligodendrócitos, na expressão de tubulina e disfunção dos microtúbulos, condizente com o quadro de atrofia dos gânglios da base e cerebelo (principais locais de expressão). Já para as variantes descritas em distonia, foi observada alteração na morfologia neuronal, enquanto a quantidade e o processo de polimerização da tubulina permaneceram normais. Portanto, o impacto em distonia está mais associado ao efeito na organização e não na formação dos microtúbulos. ${ }^{(102,103)}$

Embora uma nova variante (p.Ala271Thr) tenha sido confirmada em distonia, com fenótipo semelhante ${ }^{(66)}$ estudos seguintes em indivíduos com distonia isolada não identificaram variantes nesse gene..$^{(104-107)}$

\subsubsection{DYT- GCH1 (DYT5a), DYT-TH (DYT5b) e DDC}

Os genes GCH1, TH e DDC codificam proteínas constituintes de uma única via metabólica envolvida na fisiopatologia da distonia: a síntese de dopamina.

DYT-GCH1 (cromossomo 14q) e DYT-TH (cromossomo 11p) constituem a classe denominada "distonia dopa-responsiva", em virtude da melhora significativa dos sintomas após tratamento com levodopa (L-DOPA). São caracterizadas por um quadro de distonia-parkinsonismo, de início na infância, acometimento dos membros inferiores com interferência na marcha e flutuação diurna dos sintomas (com melhora após o sono). ${ }^{(108)}$ Esse quadro fenotípico é variável, dependente do nível de depleção dopaminérgica, com casos mais extremos relacionados com hiperfenilalaninemia, atraso no desenvolvimento motor e convulsões. Em DYT-GCH1, a maioria dos casos correspondem à herança autossômica dominante, embora casos recessivos também tenham sido reportados com um quadro neurológico mais grave. DYT-TH ocorre na forma autossômica recessiva homozigótica ou em heterozigose composta. ${ }^{(72,109-112)}$

Os genes $\mathrm{GCH} 1$ e $\mathrm{TH}$ codificam as enzimas GTP ciclohidrolase I e tirosina hidroxilase, respectivamente. GTP ciclohidrolase I atua como uma GTPase da via de síntese do cofator tetrahidrobiopterina $(\mathrm{BH} 4)$, utilizado pela enzima tirosina 
hidroxilase (codificada pelo gene $T H$ ) na catálise e conversão do aminoácido tirosina em L-DOPA, na via de síntese dopaminérgica. Portanto, variantes nesses genes podem prejudicar a atuação da enzima tirosina hidroxilase e resultar na diminuição dos níveis de dopamina no estriado. ${ }^{(113,114)}$

$\mathrm{Na}$ mesma via, o gene $D D C$ (cromossomo $7 \mathrm{p}$ ) codifica a enzima dopa descarboxilase. Uma vez que o papel dessa enzima é converter L-DOPA em dopamina, sua deficiência resulta em baixos níveis de dopamina, onde geralmente, a administração de levodopa é ineficaz, ao contrário dos casos DYT-GCH1 e DYT-TH. Portanto, seu papel nesse distúrbio está relacionado com depleção de dopamina e ao seu efeito em alterar vias de transdução de sinal mediadas por esse neurotransmissor, com um fenótipo progressivo e mais grave, intermediário entre distonia e outros distúrbios do movimento, como a doença de Parkinson. ${ }^{(115,116)}$

\subsubsection{DYT-THAP1 (DYT6)}

O gene THAP1 (cromossomo 8p) foi descrito em distonia em 2009, com padrão autossômico dominante. Essa causa genética é representada pelo lócus DYT6, caracterizada por distonia de surgimento na infância ou adolescência e fenótipo variado. Frequentemente há envolvimento crânio-cervical, disfonia ou acometimento dos membros, no qual generalização ocorre em aproximadamente metade dos casos. $^{(67,117)}$

Esse gene codifica a proteína THAP1 (proteína associada à apoptose, contendo o domínio THAP) que atua no processo de transcrição gênica neuronal, capaz de regular sua própria expressão. Possui um domínio THAP (do tipo dedo de zinco) ligante de ácido desoxirribonucleico (DNA) na porção $\mathrm{N}$-terminal, um sinal de localização celular e motivos de interação proteica na porção C-terminal. ${ }^{(67,118)}$ A proteína THAP1 é amplamente expressa e, segundo modelos animais, seus maiores níveis de expressão no sistema nervoso central estão no córtex (neurônios piramidais), estriado (neurônios espinhosos médios e colinérgicos), substância negra (neurônios dopaminérgicos) e cerebelo (células de Purkinje). Com exceção do cerebelo, os níveis de expressão tendem a diminuir com a idade. ${ }^{(119)}$

DYT-THAP1 tem sido uma causa frequentemente descrita em brasileiros. Apresenta penetrância reduzida, expressividade variável e responde ao 
tratamento com estimulação cerebral profunda, mas com menor eficiência do que nos casos DYT-TOR1A. ${ }^{(74,78,98,120,121)}$ Disfunções em regiões corticais e subcorticais foram descritas em DYT-THAP1, com aumento metabólico da área motora pré-suplementar e do córtex de associação parietal e, assim como em DYT-TOR1A, diminuição na disponibilidade do receptor D2 de dopamina no estriado. ${ }^{(122,123)}$

\subsubsection{DYT-SGCE (DYT11)}

Aproximadamente $50 \%$ dos casos de distonia combinada com mioclonia são devidos às variantes no gene SGCE (cromossomo 7q), em padrão autossômico dominante. Esse gene codifica a proteína épsilon sarcoglicana, membro da família das sarcoglicanas e, como uma proteína transmembrana, atua como componente do complexo distrofina-glicoproteína, que liga o citoesqueleto à matriz extracelular. No cérebro, é expressa no córtex, cerebelo, hipocampo e núcleos da base, onde o alelo materno é completamente metilado e não expresso (imprinting materno). ${ }^{(75,124,125)}$

Estudos envolvendo modelos animais demonstraram que a proteína alterada não é exposta na membrana plasmática dos neurônios, ficando retida no meio intracelular, até sua degradação. ${ }^{(126)}$ Além disso, foram descritas alterações nos níveis de dopamina no estriado, resultantes de uma redução na disponibilidade dos receptores de dopamina do tipo D2;(127) déficit no aprendizado e coordenação motora (relacionados à disfunção dessa proteína nas células cerebelares de Purkinje); déficit motor e mioclonia (relacionados à disfunção dessa proteína no estriado) ${ }^{(128,129)}$ e alterações na plasticidade sináptica corticoestriatal (associada à uma falha de indução de LTD nessa via, resultante da desorganização na maquinaria pós-sináptica). ${ }^{(130)}$ Tratamento cirúrgico de estimulação cerebral profunda resulta em melhora parcial dos sintomas nessa forma genética. ${ }^{(98)}$

\subsubsection{DYT-ATP1A3 (DYT12)}

O gene ATP1A3 (cromossomo 19q) está relacionado à distoniaparkinsonismo de início rápido e surgimento abrupto, desencadeada por fatores de 
estresse físico, tais como febre, exposição ao calor, exercício físico prolongado e parto ou estresse emocional. Geralmente os indivíduos acometidos demonstram resposta ruim à levodopa e ausência de resposta satisfatória ao tratamento com estimulação cerebral profunda. ${ }^{(73,98)}$

ATP1A3 codifica a subunidade catalítica a3 da bomba iônica ATPase, uma proteína de membrana que atua na hidrólise de ATP para transporte de sódio e potássio, a fim de manter o gradiente eletroquímico na membrana plasmática e garantir processos celulares como osmorregulação, transporte de moléculas iônicas e excitabilidade elétrica dos neurônios. ${ }^{(131)}$

ATP1A3 possui expressão no sistema nervoso, com atuação nos núcleos da base e cerebelo. Em modelo animal, a inibição da bomba de sódio e potássio ATP1A3 desencadeou disparos de alta frequência nas células de Purkinje, envolvidas em vias de sinalização junto aos núcleos da base. ${ }^{(44,132,133)}$

\subsubsection{DYT-PRKRA (DYT16)}

Variantes genéticas no gene PRKRA representam uma causa genética autossômica recessiva de distonia, caracterizada por início precoce, associação a sintomas parkinsonianos e baixa resposta ao tratamento anticolinérgico e dopaminérgico. Até então, DYT-PRKRA tem sido considerada uma causa rara de distonia, na qual a maioria das famílias descritas são brasileiras. ${ }^{(74,134)}$

O gene PRKRA (no cromossomo $2 q$ ) codifica a proteína PACT (proteína ativadora de PKR), localizada no citoplasma e região perinuclear onde atua na mediação do efeito de interferons em resposta à infecção por microrganismos ou estresse celular. Normalmente, PACT é inibida pela proteína TRBP (proteína ligante de RNA responsiva à transativação) e, em condições de estresse, se dissocia de TRBP e ativa PKR para inibição da síntese proteica. ${ }^{(135,136)}$

A principal variante descrita é a c.665C>T (p.Pro222Leu), capaz de alterar a afinidade de PACT, segundo estudos funcionais. Postula-se que, mediante estresse celular, a proteína PACT alterada leva mais tempo para de dissociar de TRBP gerando uma maior ativação de PKR, atrasando e amplificando a resposta intracelular ao estresse. ${ }^{(137)}$ Enquanto que a proteína PACT truncada (devido mutação frameshif), 
demonstrou diminuição na interação com ácido ribonucleico (RNA) e com TRBP, ficando livre e ativando PKR para inibição de síntese proteica. ${ }^{(138)}$

\subsubsection{DYT-CIZ1 (DYT23)}

Em 2012, ClZ1 foi reportado como causa de distonia cervical com surgimento na fase adulta, de forma autossômica dominante. O gene ClZ1 (cromossomo 9q) codifica uma proteína ligante de DNA (do tipo "dedo de zinco"), localizada no núcleo celular, com papel na replicação de DNA, no ciclo e diferenciação celular. $^{(68,139,140)}$

Das seis isoformas de $C / Z 1$, duas são expressas no sistema nervoso central (as isoformas 1 e 2), em estruturas anatômicas motoras como o córtex, cerebelo, substância negra e putâmen. Ambas são expressas nas estruturas citadas e diferem somente na quantidade, onde a isoforma 2 é expressa em maiores níveis na substância negra e no putâmen. ${ }^{(68)}$

A região C-terminal da proteína $\mathrm{CIZ1}$ se liga à matriz nuclear (em região separada da cromatina), enquanto a $\mathrm{N}$-terminal atua na replicação de DNA, resultando na formação de partículas ou focos subnucleares. ${ }^{(141)}$ Estudo funcional revelou que a proteína mutada chega a entrar no núcleo e formar as mesmas partículas em forma de focos subnucleares, porém, tais partículas são maiores e em menor quantidade em comparação com o modelo selvagem. Tal observação levantou a hipótese de um mecanismo de ganho de função com síntese de DNA aberrante. ${ }^{(68)}$

Em outros estudos, realizados em indivíduos com distonia cervical, a contribuição desse gene como causa não ficou clara. Em um estudo realizado a partir de uma família chinesa com múltiplas gerações de afetados não foi identificada nenhuma variante e, em um estudo mais amplo $(n=683)$ realizado em indivíduos de origem alemã, foi identificada somente uma variante (c.2357C>T / p.T786I) no domínio C-terminal de $\mathrm{ClZ1} .^{(142,143)}$

\subsubsection{DYT-ANO3 (DYT24)}

Distonia causada por variantes no gene $A N O 3$ (cromossomo 11p) foi descrita em 2012, juntamente com outros genes descobertos através de 
sequenciamento de nova geração. Nessa causa há alta variabilidade fenotípica, com surgimento precoce ou tardio, inicialmente descrito na região crânio-cervical e, mais recentemente, em outras partes do corpo, com presença de mioclonia ou tremor. ${ }^{(144-146)}$ DYT-ANO3 já foi identificada em outros casos de distonia, porém, diversas variantes também são encontradas em controles e bancos de dados populacionais. ${ }^{(146-148)}$

ANO3 codifica a proteína anoctamina 3, uma proteína transmembrana altamente expressa no cérebro, principalmente no estriado. Sua função está relacionada ao processo de transdução de sinal mediado por transportadores iônicos. Estudos recentes têm indicado um maior papel dessa proteína na manutenção da membrana plasmática e mitocondrial e na regulação de outros canais, ao atuar como uma scramblase, distribuindo simetricamente fosfolipídeos negativamente carregados entre a porção externa e interna da bicamada lipídica. ${ }^{(69,149)}$

\subsubsection{DYT-GNAL (DYT25)}

O gene GNAL (cromossomo 18p) também foi descrito para distonia em 2012, relacionado ao lócus DYT25 em padrão autossômico dominante. DYT-GNAL é caracterizada por distonia focal crânio - cervical de surgimento na fase adulta, com alta penetrância. ${ }^{(70,150)}$

Esse gene codifica a subunidade a da proteína Golf, expressa no estriado. Alterações nesta proteína levam a defeitos no acoplamento de proteínas G com receptores $\mathrm{D} 1$ de dopamina e $\mathrm{A} 2 \mathrm{~A}$ de adenosina e à consequentes alterações na transdução de sinal mediada pelos neurônios estriatais. ${ }^{(70,151)}$

Diversas variantes já foram descritas, e, embora a maioria dos casos seja de distonia crânio-cervical de surgimento adulto, outros fenótipos têm sido descritos, com surgimento na infância e associação à mioclonia e tremor. Fenótipos mais graves estão associados à variantes homozigóticas em GNAL. ${ }^{(152-154)}$

Tratamento com estimulação cerebral profunda se mostrou eficaz, com resultados semelhantes aos casos DYT-TOR1A. ${ }^{(155)}$ 


\subsubsection{DYT-KCTD17 (DYT26)}

O gene KCTD17 (cromossomo 22q) codifica uma proteína solúvel, que tem como característica um domínio de tetramerização do canal de potássio (proteínas KCTD). Proteínas KCTD atuam em diversos mecanismos como proliferação celular, transcrição gênica, organização citoesquelética, degradação proteica via sistema ubiquitina-proteassoma e regulação de receptores acoplados às proteínas G. Tais mecanismos já foram citados por envolvimento nas vias fisiopatológicas da distonia. A isoforma KCTD17 é expressa no cérebro com maiores níveis de expressão no estriado (putâmen) e tálamo, com aumento progressivo, do início da vida fetal ao longo do desenvolvimento cerebral humano. ${ }^{(76)}$

Até o momento, na literatura, há somente três estudos que descrevem o gene KCTD17 como causa de distonia. O estudo inicial foi reportado em 2015, a partir da investigação de duas famílias aparentemente não relacionadas (uma britânica e outra alemã) que tinham a mesma variante c.434G>A (p.Arg145His), fenótipo semelhante e segregação em todos os portadores de distonia. Apesar da predominância do fenótipo de distonia-mioclonia, a mioclonia pode não estar presente, enquanto a distonia está mais associada a um acometimento crânio-cervical. ${ }^{(76)}$ Recentemente, foram descritos mais dois casos europeus de distonia-mioclonia com surgimento na infância. Nos dois casos, o fenótipo é mais grave do que o descrito no estudo inicial, provavelmente, por serem variantes que afetam sítios de emenda éxoníntron, resultando em proteínas truncadas. Estimulação cerebral profunda do globo pálido interno foi um tratamento efetivo para essa causa, relatado em um dos casos. ${ }^{(156,157)}$

\subsubsection{Estudo das causas genéticas da distonia}

Conforme detalhado anteriormente, para a maioria das causas genéticas de distonia, há um fenótipo característico predominante (relacionado à idade e local de surgimento, distribuição final dos sintomas e resposta terapêutica), que, embora não seja determinante e aplicável em todos os casos, auxilia no prognóstico. Análise genética pontual ou por meio de painéis de genes têm sido métodos eficazes e acessíveis para diagnóstico e estudos populacionais, enquanto sequenciamento do 
exoma tem sido extremamente útil na descoberta de novos genes. ${ }^{(10,158)}$ Hoje, o diagnóstico genético em distonia auxilia na indicação de tratamentos específicos, principalmente em relação ao tratamento cirúrgico, e na reclassificação de casos esporádicos ou familiares tidos como idiopáticos. ${ }^{(159)}$

Nosso grupo de pesquisa tem interesse em estudar o quanto e como variantes genéticas contribuem para a distonia, em suas diversas apresentações clínicas. Nesse sentido, o primeiro passo foi identificar quais são essas variantes e qual a causa genética mais frequente em nossa amostra. Em estudos prévios, identificamos variantes potencialmente patológicas nos genes TOR1A, GCH1, THAP1, SGCE e GNAL, em parte dos indivíduos que compõem a "Rede Brasileira para Estudo das Distonias". ${ }^{(120,160)}$ Entretanto, boa parte deles permaneceu sem diagnóstico molecular, além dos indivíduos com distonia recrutados posteriormente aos estudos citados.

Nesse estudo, identificamos variantes alélicas com possível contribuição causal em distonia, determinando suas frequências em nossa amostra e correlacionando o genótipo identificado com os fenótipos, a fim de comparar nossos achados com os de outras populações estudadas. Além disso, os resultados provenientes dessa pesquisa contribuem para uma melhor compreensão da atuação desses genes alterados dentro do mecanismo fisiopatológico envolvido nas distonias.

\subsection{Objetivos}

1. Padronizar a análise molecular de variantes nos genes TOR1A, TUBB4, GCH1, TH, DDC, THAP1, SGCE, ATP1A3, PRKRA, CIZ1, ANO3, GNAL e $K C T D 17$, por meio da técnica de sequenciamento em larga escala por painel customizado (targeted resequencing) e confirmação das variantes encontradas por sequenciamento Sanger;

2. Identificar variantes genéticas potencialmente patogênicas e sua prevalência nos indivíduos com distonia idiopática;

3. Caracterizar o potencial patogênico das variantes encontradas por meio de análises in silico (via algoritmos de bioinformática e modelagem molecular), inferindo o quanto elas interferem na função proteica;

4. Estabelecer correlações genótipo x fenótipo. 


\section{MÉTODOS}

\subsection{Aspectos éticos}

A Rede Brasileira para Estudo das Distonias (RBED) é um estudo observacional multicêntrico desenvolvido há aproximadamente 10 anos. Tem como objetivo estabelecer uma rede nacional permanente para estudo da distonia, caracterizando o perfil clínico e molecular desse distúrbio do movimento na população brasileira. É desenvolvido no Instituto Israelita de Ensino e Pesquisa Albert Einstein e, até o momento, conta com a participação de centros especializados em transtornos do movimento de São Paulo, tais como o Departamento de Neurologia e Neurocirurgia da Universidade Federal de São Paulo (UNIFESP), o Departamento de Neurologia da Faculdade de Medicina da Universidade de São Paulo (FMUSP), o Setor de Neurologia do Hospital do Servidor Público Estadual e o Hospital Santa Marcelina.

Como parte do projeto RBED, o presente estudo foi aprovado pelos comitês de ética em pesquisa dos principais centros envolvidos (CEP 10/1434 e 1704/10). Todos os participantes (probandos e controles) assinaram o Termo de Consentimento Livre e Esclarecido (TCLE), o qual foi aplicado respeitando a autonomia, sigilo e confidencialidade dos dados e garantindo a atualização dos participantes quanto aos resultados obtidos, quando solicitado.

\subsection{Participantes}

A fase de recrutamento dos participantes foi realizada através do projeto RBED, citado anteriormente. As avaliações clínicas foram realizadas por neurologistas com ampla experiência em transtornos do movimento nas instituições participantes, e revisadas pela Dra. Patrícia Aguiar (coordenadora do projeto RBED e orientadora dessa tese). Por ocasião da aplicação do TCLE, todos os participantes passaram pela etapa inicial do aconselhamento genético.

Conforme classificação definida em literatura (detalhada no item 1.2 desse manuscrito), consideramos os seguintes critérios de inclusão e exclusão para recrutamento dos indivíduos com distonia:(1) 
- Critério de inclusão: diagnóstico de distonia isolada ou distonia combinada (com mioclonia / parkinsonismo).

- Critérios de exclusão: Diagnóstico genético prévio ou evidências de causa secundária para a distonia ou de doença neurodegenerativa.

Anteriormente, já havíamos investigado variantes genéticas em grande parte dos indivíduos incluídos nesse estudo ( $n=139)$. Essa investigação ocorreu nos genes TOR1A e THAP1 (que foram descritos como causas frequentes de distonia), nos genes GCH1 e SGCE (em alguns casos com fenótipo específico de distonia doparesponsiva e distonia-mioclonia responsiva ao álcool) e no gene GNAL (por ter sido uma causa focal recentemente descoberta). ${ }^{(120,160)}$ No presente estudo, incluímos os 139 pacientes que participaram das investigações anteriores e que ainda estavam sem diagnóstico molecular, bem como 16 casos novos ainda sem investigação genética.

Os indivíduos que atenderam aos critérios de inclusão e exclusão estabelecidos foram selecionados para análise genética, constituindo o grupo amostral desse estudo, conforme ilustrado na figura 7.

Para comparação de frequência das variantes alélicas encontradas nos indivíduos com distonia, selecionamos participantes controles brasileiros saudáveis, de ambos os sexos, maiores de idade, sem parentesco com os probandos e sem história de distonia na família. Tal abordagem foi realizada durante o ano de 2017 , e posteriormente, passamos a utilizar os bancos de dados genéticos brasileiros AbraOM (Arquivo Brasileiro Online de Mutações) ${ }^{(161)}$ e BipMed (Brazilian Initiative on Precision Medicine $)^{(162)}$ para tal comparação, uma vez que são compostos por genomas de amostras representativas da população brasileira, substituindo o grupo controle. ${ }^{(163)}$ 


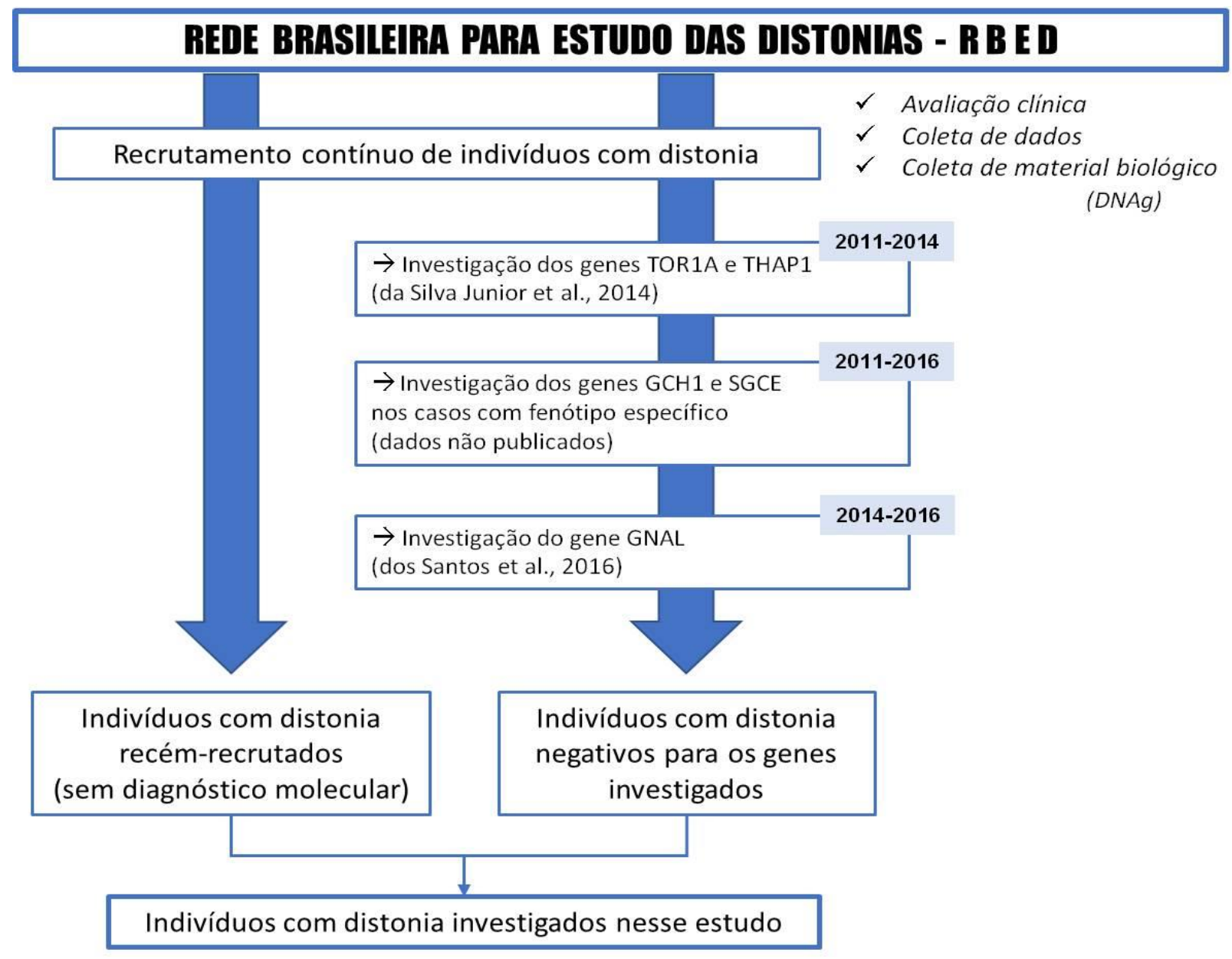

A rede brasileira para estudo das distonias (RBED) recruta continuamente indivíduos com distonia, acompanhados nos centros participantes. Os casos idiopáticos (negativos para causa genética em estudos anteriores) ( $n=139)$ foram selecionados para investigação genética nesse estudo, somados aos indivíduos recém recrutados $(n=16)$ que atendiam aos critérios de inclusão e exclusão desse estudo. Total de probandos $\mathrm{N}=153$.

Figura 7. Seleção amostral dos indivíduos com distonia incluídos nesse estudo

\subsection{Sequenciamento em larga escala}

A análise genética foi realizada a partir de DNA genômico (DNAg), extraído de $6 \mathrm{ml}$ de sangue periférico (coletados em tubos com o anticoagulante ácido etilenodiamino tetra acético (EDTA)) de todos os probandos e, quando disponível, dos familiares deles para análise de segregação e impacto das variantes genéticas.

A extração do DNAg foi realizada através do kit Gentra Puregene ${ }^{\circledR}$ Blood (Qiagen Sciences), conforme instruções do fabricante. Resumidamente, nesse processo as células vermelhas e brancas foram lisadas com detergente iônico e outros contaminantes (como proteínas) foram removidos pela adição de reagente de precipitação salina. O DNAg foi precipitado com isopropanol $100 \%$, purificado com 
etanol $70 \%$ e eluído em solução de hidratação (1 $1 \mathrm{mM}$ EDTA, $10 \mathrm{mM}$ Tris $\cdot \mathrm{Cl}$, pH 7,5). Posteriormente, alíquotas dessas amostras foram diluídas para 25 nanogramas por microlitro $(\mathrm{ng} / \mu \mathrm{L})$, conforme quantificação realizada pelo método fluorimétrico Qubit ${ }^{\circledR}$ Double strand DNA (Thermo Fisher Scientific) que demonstra alta sensibilidade e especificidade para quantificação de DNA.

Utilizamos o método de ressequenciamento direcionado por amplicons, através de um painel genético customizado, para obter a sequência de nucleotídeos das regiões de interesse. Tal método consiste em isolar e sequenciar regiões de genes específicos (determinadas previamente por um painel customizado), no qual a busca por variantes genéticas se torna direcionada para essas regiões, reduzindo o custo, tempo de preparo, tempo de análise do sequenciamento e garantindo maior especificidade e cobertura de aprofundamento dessas regiões para identificação de variantes raras. Além disso, o uso do método por meio de amplicons (ideal para análise inferior a 50 genes) dispensa etapas complexas como a de fragmentação do DNA, uma vez que gera fragmentos complementares às regiões de interesse e os alinha ao genoma humano de referência na comparação e identificação de variantes..$^{(164)}$

Em relação ao procedimento, o ressequenciamento direcionado ocorreu em três etapas: 1. Desenho do painel de genes (para determinação das regiões que foram sequenciadas), 2. Construção das bibliotecas (para formação dos amplicons correspondentes às regiões de interesse desenhadas no painel), e 3 . Sequenciamento (para a amplificação, leitura e análise primária das sequências). A seguir, cada etapa está descrita em detalhes.

\subsubsection{Desenho do painel}

A princípio, desenhamos um painel customizado com as regiões genômicas de interesse, através do software Design Studio (Illumina ${ }^{\circledR}$, Inc) disponível na web. Buscamos abranger as regiões dos éxons, as regiões de emenda éxon / íntron e as regiões 3' e 5' não traduzidas (UTR - Untranslated Region) de treze genes descritos para distonia: TOR1A, TUBB4A, GCH1, TH, DDC, THAP1, SGCE, ATP1A3, PRKRA, CIZ1, ANO3, GNAL e KCTD17. 
As isoformas de cada gene (consideradas no desenho do painel e posterior análise) estão descritas no quadro 2, conforme cada banco de dados. Foram selecionadas com base na literatura, levando em conta sua expressão no sistema nervoso central ou a isoforma mais longa.

Quadro 2. Isoformas dos genes investigados nesse estudo

\begin{tabular}{|lllllll|}
\hline \multirow{2}{*}{ GENE } & \multirow{2}{c}{ RefSeq } & Transcrito & Proteína & UNIPROT & Tamanho \\
& Transcrito & Proteína & (ENST00000) & (ENSP00000) & & \\
TOR1A & NM_000113 & NP_000104.1 & 351698.4 & 345719 & O14656 & 332 aa \\
TUBB4A & NM_006087.3 & NP_06078.2 & 264071.6 & 264071 & P04350 & 444 aa \\
GCH1 & NM_000161 & NP_000152.1 & 622544.4 & 477796 & P30793 & 250 aa \\
TH & NM_199292.2 & NP_954986.2 & 381178.5 & 370571 & P07101 & 528 aa \\
THAP1 & NM_018105 & NP_060575.1 & 254250.7 & 254250 & Q9NVV9 & 213 aa \\
SGCE & NM_001099401 & NP_001092871 & 445866.7 & 398930 & O43556 & 462 aa \\
ATP1A3 & NM_152296 & NP_689509.1 & 302102.9 & 302397 & P13637 & 1013 aa \\
PRKRA & NM_003690 & NP_003681.1 & 325748.8 & 318176 & O75569 & 313 aa \\
CIZ1 & NM_001257975 & NP_001244904 & 538431.5 & 439244 & F5H2X7 & 954 aa \\
ANO3 & NM_031418 & NP_113606.2 & 256737.7 & 256737 & Q9BYT9 & 981 aa \\
GNAL & NM_182978 & NP_892023.1 & 334049.1 & 334051 & P38405 & 458 aa \\
KCTD17 & NM_001282684 & NP_1269613 & 403888.7 & 385096 & Q8N5Z5 & 321 aa \\
DDC & NM_001082971 & NP_001076440 & 444124.6 & 403644 & P20711 & 480 aa \\
\hline
\end{tabular}

RefSeq (Reference Sequence - NCBI); Ensembl (European Bioinformatics Institute - EMBL-EBI); UNIPROT (Universal Protein Resource); aa (aminoácidos).

\subsubsection{Construção das bibliotecas}

Para o processo de construção das bibliotecas e preparo da reação de sequenciamento, utilizamos os kits TruSeq Custom Amplicon Assay v1.5 (Illumina ${ }^{\circledR}$, Inc) e TruSeq Custom Amplicon Index (Illumina ${ }^{\circledR}$, Inc), customizados para o painel desenhado anteriormente.

Hibridização dos oligos: Conforme instruções do fabricante, inicialmente, os oligos desenhados no painel (que são correspondentes às extremidades das regiões de interesse) foram hibridizados junto às amostras de DNAg dos probandos (Figura 8A). Essa reação de hibridização consistiu na adição de $250 \mathrm{ng}$ do DNAg dos probandos junto à solução com os amplicons customizados e uma 
solução de hibridização, com ciclos rápidos de centrifugação e incubação a 95ㄷ por 1 minuto e 80 minutos de incubação, com diminuição gradual da temperatura até $40^{\circ} \mathrm{C}$.

Remoção dos oligos não hibridizados: Em uma segunda reação, os oligos não hibridizados foram removidos com a utilização de uma placa filtro, na qual os fragmentos hibridizados foram selecionados por tamanho e propriedades químicas de retenção no filtro. Resumidamente, após adição das amostras (que passaram pelo processo anterior de hibridização) em uma placa filtro, foram realizados dois processos de lavagem (adição da solução de lavagem seguida por centrifugação), no qual os fragmentos hibridizados ficaram retidos na placa filtro e os oligos não hibridizados que passaram pelo mesmo foram descartados.

Extensão - ligação: Ainda com os fragmentos hibridizados retidos no filtro, iniciamos o processo de extensão-ligação, ou seja, processo onde é formada uma cópia complementar à região de interesse com os oligos ligados às suas extremidades upstream e downstream. Após adição da solução de extensão-ligação à amostra hibridizada retida na placa filtro, a incubamos a $37^{\circ} \mathrm{C}$ por 45 minutos. Nesse processo, a partir da ação da enzima DNA polimerase, ocorreu a extensão do oligo upstream 3' passando pela região de interesse até a ligação do oligo downstream na terminação 5' da fita (Figura 8B).

Amplificação por reação em cadeia da polimerase (PCR Polymerase Chain Reaction): Em seguida, adicionamos nas extremidades dos fragmentos as sequências adaptadoras necessárias para a reação de sequenciamento, denominadas "index" (que servem como identificadores das amostras no processo de geração dos clusters) e os primers (Figura 8C e D). Para tal reação, adicionamos hidróxido de sódio $(\mathrm{NaOH})$ [50mM] à placa filtro para liberação e eluição dos fragmentos retidos e, após centrifugação, adicionamos a combinação de primers e sequências "index" específicos para cada amostra, junto com uma solução de mistura para reação de PCR com a enzima DNA polimerase. A placa foi submetida às seguintes condições de termociclagem: $95^{\circ} \mathrm{C}$ por 3 minutos, seguido por 26 ciclos de $95^{\circ} \mathrm{C}$ por 30 segundos, $66^{\circ} \mathrm{C}$ por 30 segundos e $72^{\circ} \mathrm{C}$ por 60 segundos e finalização $\operatorname{com} 72^{\circ} \mathrm{C}$ por 5 minutos. O produto foi mantido a $10^{\circ} \mathrm{C}$ até seu uso. 
A)

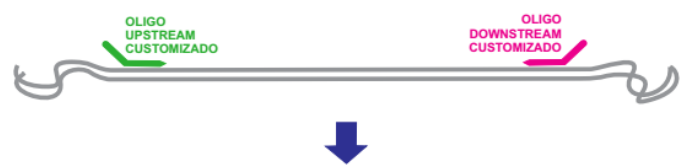

B)

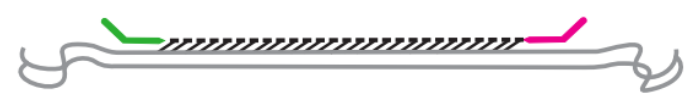

C)

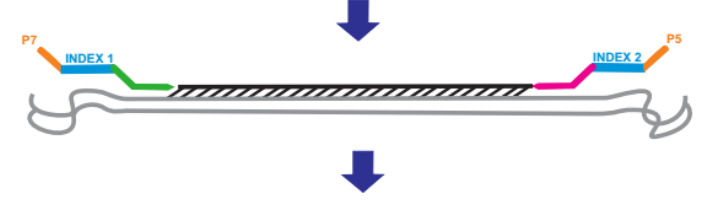

D)

REGIAO DE INTERESS

INDEXX PS

A) Oligos (verde e rosa) correspondentes às extremidades das regiões de interesse foram hibridizados com o DNA genômico (DNAg) de cada amostra (cinza). B) Processo de extensão a partir do oligo upstream até o oligo downstream. C) Sequências index (azul) e primers de sequenciamento (laranja) também foram adicionados aos fragmentos para sua amplificação no processo de geração dos clusters D) Amplicon contendo a região de interesse, as sequências adaptadoras e primers.

Fonte: Adaptado do protocolo de instruções TruSeq ${ }^{\circledR}$ Custom Amplicon (Illumina ${ }^{\circledR}$ ).

Figura 8. Etapas da tecnologia de ressequenciamento direcionado por amplicons

Para verificar se houve a construção correta da biblioteca, foi feita a quantificação por meio de gel de agarose $4 \%$, com um fragmento esperado de aproximadamente 570 pares de base (correspondente ao tamanho dos amplicons de $425 \mathrm{pb}$ somado aos adaptadores).

Para garantir a qualidade do sequenciamento, as amostras foram purificadas através do método de seleção por beads (esferas magnéticas). Tal processo ocorreu mediante adição das beads magnéticas junto às amostras, ciclos de agitação em aparelho e incubação da placa em rack magnética para retenção das beads. Em um primeiro momento, após adição de etanol $80 \%$, as amostras ficaram retidas junto às beads e o sobrenadante foi descartado. Em um segundo momento, após adição do tampão de eluição com Tris, as amostras foram liberadas das beads (que ficaram retidas após uso da rack magnética), e transferidas para uma nova placa.

Para garantir a eficiência do processo de amplificação no momento do sequenciamento, foi necessário atestar que volumes iguais de cada biblioteca fossem combinados, diluídos em solução tampão e desnaturados para o sequenciamento, processo conhecido como normalização da biblioteca. O processo de normalização foi realizado a partir da adição das beads magnéticas junto às amostras purificadas e uma solução de aditivos para normalização, um ciclo de agitação por 30 minutos, retenção das beads após incubação da placa na rack magnética e descarte do sobrenadante. Com as amostras retidas junto às beads, adicionamos solução de 
lavagem seguida por novo ciclo de agitação, retenção e descarte do sobrenadante. Para eluição e liberação das amostras retidas junto às beads, adicionamos $\mathrm{NaOH}$ [0.1N], e após novo ciclo de agitação e retenção das beads as amostras foram transferidas para uma nova placa.

Por fim, $5 \mu \mathrm{L}$ de cada biblioteca foram transferidos para um único tubo, considerando que as sequências index (inseridas durante a construção das bibliotecas) permitiriam a identificação de cada amostra. Dessa mistura, retiramos $6 \mu \mathrm{L}$ e misturamos com $594 \mu \mathrm{L}$ da solução tampão. Após incubação para desnaturação e adição da amostra de controle interno (que atesta a eficiência do processo de sequenciamento), as bibliotecas foram carregadas no cartucho de reagentes (um cartucho pré-carregado com reagentes necessários para a clusterização e o sequenciamento) antes de inseri-lo no aparelho.

\subsubsection{Sequenciamento}

As amostras foram sequenciadas utilizando o kit MiSeq Reagent v2 (Illumina $^{\circledR}$, Inc), na plataforma MiSeq System (Illumina ${ }^{\circledR}$, Inc). Nessa plataforma, durante a execução, as bibliotecas foram transferidas automaticamente do cartucho de reagentes para a lâmina de fluxo, onde foram gerados os clusters e realizada a reação de sequenciamento. A clusterização consiste em um processo onde as moléculas de DNA em fita simples são ligadas à superfície da lâmina de fluxo e amplificadas por processo de formação em pontes para formar grupos aglomerados. Após clusterização, foram geradas imagens dos clusters conforme as marcações fluorescentes dos dideoxinucletídeos fosfatados (ddNTP's) e iniciada a análise em tempo real para identificação das bases.

\subsubsection{Análise das sequências obtidas}

Na plataforma MiSeq System (Illumina ${ }^{\circledR}$, Inc), as amostras passaram por uma análise em tempo real onde foram realizadas etapas primárias como a identificação das bases, a análise das imagens e a atribuição de pontuação de qualidade para cada base (o qual fornece uma previsão de probabilidade de erro das 
bases identificadas - escore Phred -Q). A partir do aplicativo MiSeq Reporter, as sequências lidas (reads) foram alinhadas ao genoma humano de referência (Feb.2009/GRCh37/hg19) com o algoritmo Smith-Waterman-Gotoh e a remoção de duplicatas de PCR foi feita pelo algoritmo SAM tools (Figura 9).

Após o alinhamento, para identificação das variantes genéticas de cada amostra (substituições, inserções e deleções), utilizamos o aplicativo Genome Analysis Toolkit (que contém os softwares GATK para chamada de variantes e IONA para anotação) disponíveis na plataforma BaseSpace (Illumina ${ }^{\circledR}$, Inc). Para a investigação de variantes estruturais, contamos com a colaboração do bioinformata Renato David Puga, o qual realizou análise pelo algoritmo Pindel, capaz de identificar deleções maiores (de 1 até 10.000 pares de base) e inserções de até 20 pares de base, comparando as sequências foward $\left(5^{\prime} \rightarrow 3^{\prime}\right)$ e reverse $\left(3^{\prime} \rightarrow 5^{\prime}\right)$ da amostra com o genoma de referência. ${ }^{(165)}$ Para visualização dos alinhamentos e variantes identificadas utilizamos o software Integrative Genomic Viewer (IGV) (Figura 9).

Plataforma MiSeq System (IIlumina ${ }^{\circledR}$, Inc)

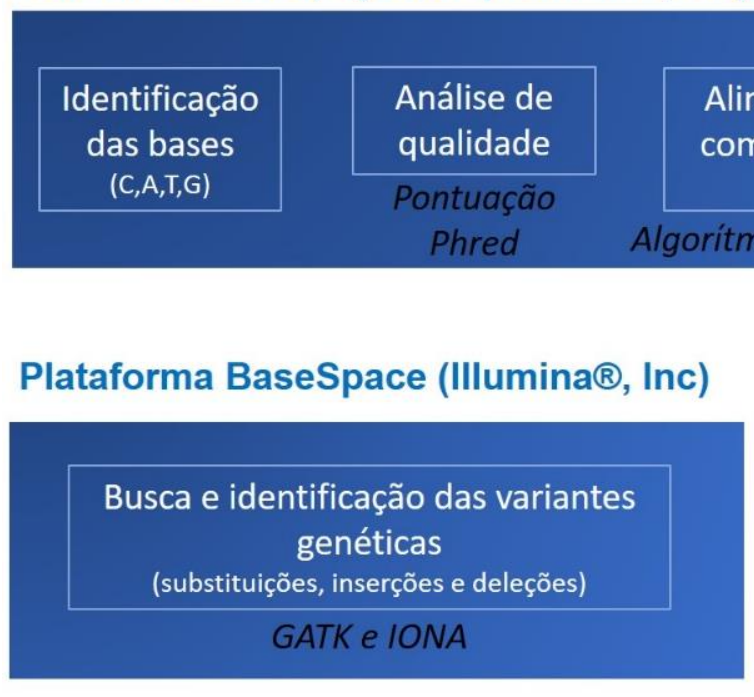

Alinhamento dos reads

com genoma referência (GRCh37/hg19)

Algorítmo Smith-Waterman-Gotoh

Remoção de duplicatas de PCR

Sam tools

Colaboração Bioinformata Renato David Puga

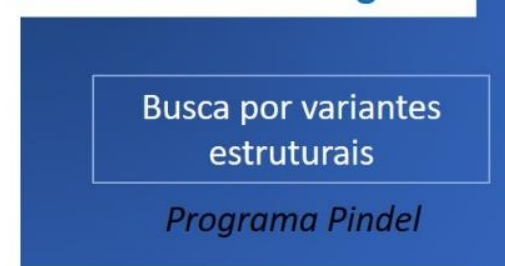

Priorização das variantes

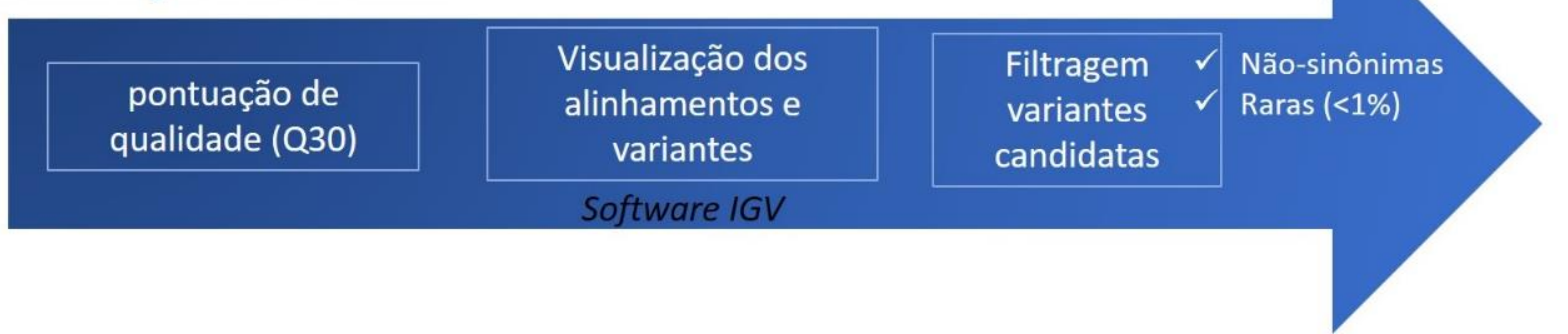

Figura 9. Processo de análise bioinformática das sequências obtidas e priorização das variantes 


\subsubsection{Priorização e validação das variantes}

Para o processo de filtragem e priorização de variantes consideramos alguns critérios conforme o impacto da variante na função proteica. Foram desconsideradas variantes sinônimas em regiões codificantes (uma vez que não alteram a sequência peptídica da proteína) e variantes classificadas como benignas (variantes com alta frequência nos bancos de dados populacionais e/ou descritas como benignas). Priorizamos variantes que alteravam a sequência de aminoácidos da proteína (não sinônimas), quaisquer variantes nas regiões de emenda éxon-íntron e variantes nas regiões promotoras com potencial impacto nos processos de transcrição e tradução da proteína.

As amostras com as variantes priorizadas foram sequenciadas pela técnica de Sanger para confirmação e validação. O sequenciamento Sanger consistiu das etapas descritas a seguir.

Primeiramente, as regiões de interesse foram amplificadas por PCR a partir de aproximadamente $120 \mathrm{ng}$ de DNAg, adicionados à $50 \mathrm{pmol} / \mathrm{L}$ do primer senso, $50 \mathrm{pmol} / \mu \mathrm{L}$ do primer antissenso (Invitrogen $\left.{ }^{\mathrm{TM}}, \mathrm{BR}\right)$, solução tampão $(200 \mathrm{mM}$ de tris-(hidroximetil)-aminometano e ácido clorídrico (Tris- $\mathrm{HCl}$ ) com $500 \mathrm{mM}$ de cloreto de potássio $(\mathrm{KCl})-\mathrm{pH}^{8.4}$ ) (Invitrogen $\left.{ }^{\mathrm{TM}}, \mathrm{BR}\right), 125 \mathrm{mM}$ de dNTP (Invitrogen ${ }^{\mathrm{TM}}, \mathrm{BR}$ ), $50 \mathrm{mM}$ de cloreto de magnésio (Invitrogen ${ }^{\mathrm{TM}}, \mathrm{BR}$ ), 0,8 unidades da enzima taq DNA polimerase (Invitrogen ${ }^{\mathrm{TM}}, \mathrm{BR}$ ) e água para completar um volume final de $30 \mu \mathrm{L}$. A termociclagem da reação foi de $94^{\circ} \mathrm{C}$ por 5 minutos, 35 ciclos de $94^{\circ} \mathrm{C}$ por 30 segundos (para desnaturação do DNA), 56-60 por 30 segundos (para anelamento dos primers) e $72^{\circ} \mathrm{C}$ por 35 segundos (para extensão ou polimerização), finalizada por um ciclo de $72^{\circ} \mathrm{C}$ por mais 10 minutos e mantida a $4^{\circ} \mathrm{C}$ até seu uso. Em alguns genes, por serem regiões ricas em GC (guanina e citosina), utilizamos o kit Long Range PCR (QIAGEN ${ }^{\circledR}$ ), seguindo a termociclagem de $93^{\circ} \mathrm{C}$ por 3 minutos, 35 ciclos de $93^{\circ} \mathrm{C}$ por 15 segundos para desnaturação, $58-62^{\circ} \mathrm{C}$ por 30 segundos para anelamento e $68^{\circ} \mathrm{C}$ por 1 minuto para extensão e mantido a $4^{\circ} \mathrm{C}$ até seu uso.

O produto amplificado foi verificado por eletroforese em gel de agarose $1,5 \%$ (UltraPure ${ }^{\mathrm{TM}}$ Agarose, Invitrogen ${ }^{\mathrm{TM}}, \mathrm{BR}$ ) e purificado com as enzimas exonuclease e fosfatase alcalina do kit Illustra ${ }^{\mathrm{TM}}$ ExoStar (GE Healthcare Life Sciences, UK). Conforme instruções do fabricante, uma mistura de $5 \mu \mathrm{L}$ do produto de PCR com 10 unidades $(1 \mu \mathrm{L})$ de cada enzima foram incubados a $37^{\circ} \mathrm{C}$ por 15 minutos e a $80^{\circ} \mathrm{C}$ 
por mais 15 minutos. Por resultar em um produto muito concentrado, foi necessária sua diluição com adição de $21 \mu \mathrm{L}$ de água (proporção de 1:3) antes da reação de sequenciamento.

O produto de PCR purificado foi submetido à reação de sequenciamento com o kit BigDye ${ }^{\circledR}$ Terminator Cycle Sequencing v3.1 (Applied Biosystems, USA) conforme instruções do fabricante. Essa reação ocorreu a partir de $10 \mathrm{ng}$ do produto de PCR, com $5 \mathrm{pmol} / \mu \mathrm{L}$ de primer senso ou antissenso (Invitrogen ${ }^{\mathrm{TM}}$ ), $1 \mu \mathrm{L}$ do reagente BigDye ${ }^{\circledR}$ Terminator Cycle Sequencing, mais $1,5 \mu \mathrm{L}$ do reagente BigDye® Terminator v1.1/3.1 Sequencing Buffer $(5 \mathrm{X})$ e água para completar 10 $\mu \mathrm{L}$. A mistura desses reagentes foi submetida a períodos de termociclagem de $96^{\circ} \mathrm{C}$ por 1 minuto seguido por 25 ciclos de $96^{\circ} \mathrm{C}$ por 10 segundos, $50^{\circ} \mathrm{C}$ por 5 segundos e $60^{\circ} \mathrm{C}$ por 4 minutos e mantidas a $4^{\circ} \mathrm{C}$ até precipitação.

A etapa de precipitação desse produto foi feita com EDTA e etanol, seguindo protocolo fornecido pelo fabricante. Consiste na adição de $5 \mu \mathrm{L}$ de EDTA a $125 \mathrm{mM}$ e de $60 \mu \mathrm{L}$ de etanol $100 \%$ ao produto da reação de sequenciamento, com incubação a temperatura ambiente por 15 minutos seguida de centrifugação por 40 minutos a 3600rpm. Após centrifugação, esse produto foi purificado com adição de $60 \mu \mathrm{L}$ de etanol $70 \%$ e, após mais 15 minutos de centrifugação a $4^{\circ} \mathrm{C}$ a $3600 \mathrm{rpm}$, o sobrenadante foi descartado. Com o produto purificado e seco (sem indícios aparentes de etanol), foram adicionados $20 \mu \mathrm{L}$ de formamida $\left(\mathrm{HiDi}^{\mathrm{TM}}\right.$ Formamide, Applied Biosystems, USA) e feita incubação por 5 minutos a $95^{\circ} \mathrm{C}$ para ressuspensão e desnaturação do DNA. A partir de então, as amostras foram inseridas no instrumento ABI 3500 XL (Applied Biosystems) e sequenciadas por eletroforese capilar.

As sequências de DNA foram analisadas no software Chromas Lite 2.1.1 (disponível em http://technelysium.com.au/) e comparadas à sequência referência do banco de dados GenBank ${ }^{\circledR}$ com a ferramenta BLAST (Basic Local Alignment Search Tool - disponível em http://blast.ncbi.nlm.nih.gov/Blast.cgi).

\subsection{Análise de patogenicidade das variantes genéticas}

Para interpretação das variantes encontradas, utilizamos os seguintes critérios: 1. Frequência em bancos de dados populacionais; 2. Análises evolutivas de conservação do aminoácido afetado; 3. Domínios e regiões estruturais 
afetadas; 4. Análises in silico de predição de patogenicidade e efeito molecular; 5. Presença da variante em familiares afetados, quando disponíveis para análise; 6. Correlação genótipo-fenótipo.

\subsubsection{Frequência da variante em bancos de dados populacionais}

Verificamos a frequência alélica das variantes identificadas nesse estudo em bancos de dados genéticos populacionais de domínio público. Esses bancos são constituídos de variantes alélicas presentes na população geral, representando amostras populacionais.

O Single Nucleotide Polymorphims database $(\mathrm{dbSNP})^{3}$ arquiva variantes pontuais de substituição e pequenas inserções / deleções identificadas na população geral ou relacionadas com determinadas doenças. ${ }^{(166)}$ É útil principalmente na consulta de variantes já descritas, uma vez que, atribui às variantes submetidas um código de identificação amplamente utilizado (indicado pelo prefixo "rs"), e informa o projeto pelo qual a variante foi identificada, sua frequência e origem regional.

O projeto 1000genomes foi desenvolvido entre 2008 e 2015 com o objetivo de identificar e divulgar variantes frequentes em diversas populações. Hoje, esse projeto é gerenciado pelo International Genome Sample Resource (IGSR) e consultas podem ser realizadas através da plataforma Ensembl (disponível em: http://grch37.ensembl.org/Homo_sapiens/Info/Index). ${ }^{(167)}$

Atualmente, a maior plataforma disponível é a Genome Aggregation Database (gnomAD) ${ }^{4}$, com dados genéticos de mais de 140.000 indivíduos. Anteriormente, esse banco era conhecido como Exome Aggregation Consortium (ExAC), quando demonstrava somente dados de exomas. Hoje, é um dos bancos de dados amplos mais atuais disponível, englobando diversos projetos de sequenciamento e oferecendo esses dados agregados e harmonizados em um único layout, inclusive o projeto 1000 genomes. $^{(168)}$

O BipMed é a unidade do Projeto Varioma Humano (Human Variome Project) no Brasil. Esse projeto foi criado em 2015 a partir de instituições apoiadas pela Fundação de Amparo à Pesquisa do Estado de São Paulo (FAPESP) com a finalidade

\footnotetext{
${ }^{3}$ Disponível em: https://www.ncbi.nlm.nih.gov/snp

${ }^{4}$ Disponível em: https://gnomad.broadinstitute.org/
} 
de integrar a coleta, organizar, interpretar e divulgar variações do genoma humano em brasileiros. $^{(162)}$

O ABraOM é um repositório com exomas de mais de 600 idosos recrutados em São Paulo (disponível em: http://abraom.ib.usp.br/index.php). Foi criado pelo Centro de Estudos do Genoma Humano e Células Tronco (CEGH-CEL) do Instituto de Biociências da Universidade de São Paulo (IB-USP) com o objetivo de demonstrar a variabilidade genética brasileira. ${ }^{(161)}$

Como distonia é um distúrbio raro, dentre o qual causas genéticas representam uma pequena proporção dos casos, variantes com frequência acima de $1 \%$ nos bancos de dados citados acima foram desconsideradas das análises posteriores. Tal abordagem foi adotada com a finalidade de reduzir a descrição de variantes falso-positivas, uma vez que, uma variante com frequência $>1 \%$ na população geral teria uma frequência superior à da doença. ${ }^{(163)}$

Além dos bancos de dados populacionais, consultamos também a frequência das variantes em bancos de dados genéticos específicos de doenças, como - ClinVar e o Leiden Open Variation Database - Locus Specific Mutation Databases (LOVD/LSMD). Variantes descritas como benignas nesses bancos de dados também foram desconsideradas das análises posteriores.

O ClinVar $^{5}$ é um repositório que tem como foco variantes relacionadas com doenças a partir de evidências científicas. Engloba variantes de testes clínicos diagnósticos, de pesquisas científicas ou estudos já publicados, classificando-as conforme significância clínica em benigna, provavelmente benigna, de significado incerto, provavelmente patogênica e patogênica. ${ }^{(169)}$ Atualmente, esse sistema de classificação está sendo baseado nos critérios estabelecidos pelo American College of Medical Genetics and Genomics (ACMG) e pela Association for Molecular Pathology (AMP). ${ }^{(163)}$

Já a plataforma LOVD / LSMD permite o acesso a bancos de dados específicos de doenças ou distúrbios onde o gene em questão foi citado, como por exemplo, o "Neurodegenerative Diseases Variation Database" (NDDVD). ${ }^{(170)}$

\footnotetext{
${ }^{5}$ Disponível em https://www.ncbi.nlm.nih.gov/clinvar/
} 


\subsubsection{Conservação do aminoácido ao longo da evolução}

Inicialmente, identificamos espécies com proteínas ortólogas em relação às proteínas de interesse por meio do recurso Homologene ${ }^{6}$ (disponibilizado na plataforma NCBI). Para cursar um perfil evolutivo entre as espécies selecionadas, verificamos as classes taxonômicas na plataforma "Taxonomy Browser"” do NCBI. As espécies selecionadas, assim como sua posição na escala taxonômica e o grau de conservação dos genes investigados nesse estudo estão descritos na figura 10.

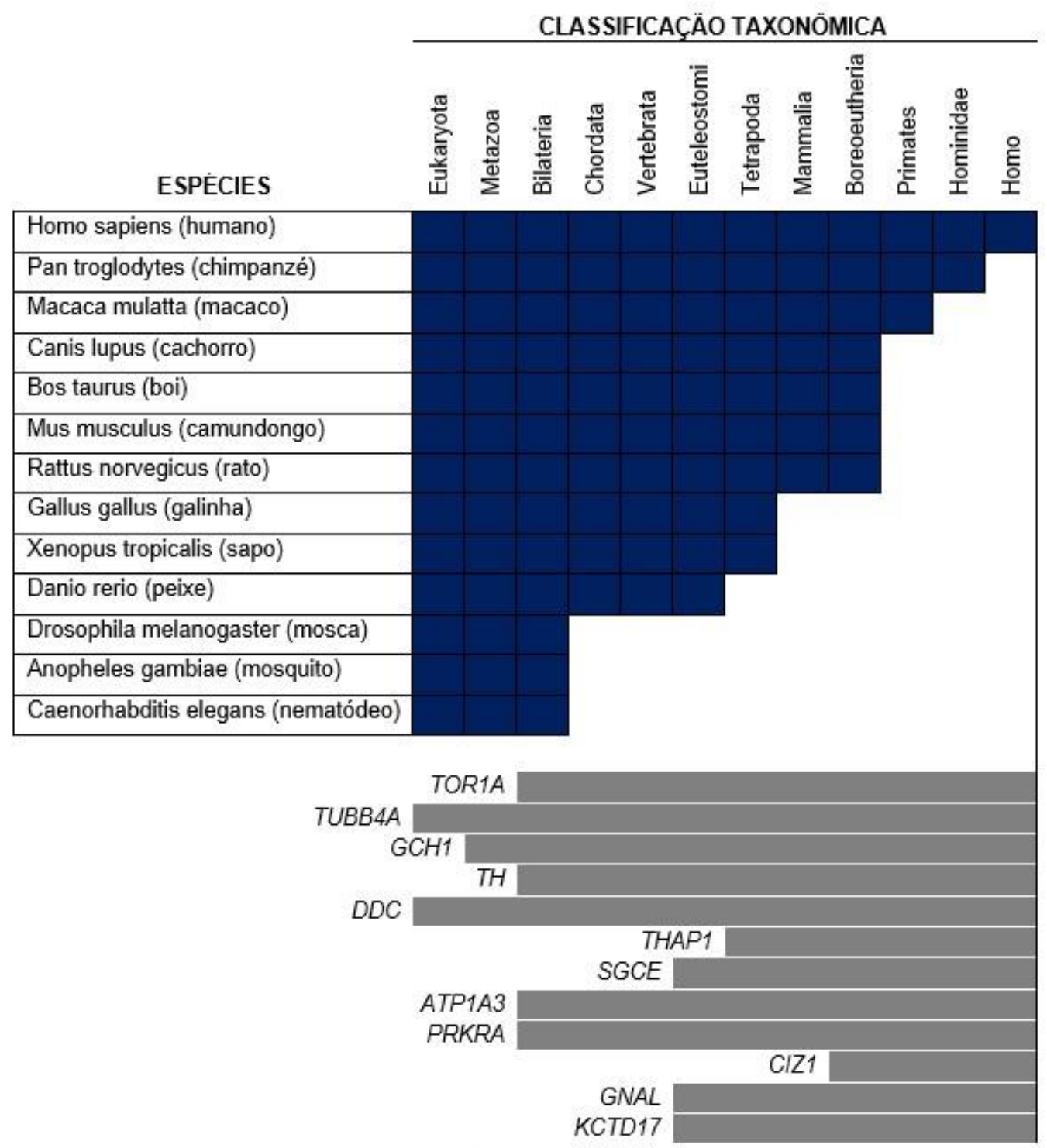

Grau de conservação do gene (Homologene, NCBI)

Figura 10. Classificação taxonômica das espécies selecionadas e grau de conservação dos genes de interesse ao longo da evolução

\footnotetext{
${ }^{6}$ Disponível em: https://www.ncbi.nlm.nih.gov/homologene/

${ }^{7}$ Disponível em https://www.ncbi.nlm.nih.gov/taxonomy
} 
Em seguida, acessamos as sequências proteicas de cada espécie no banco de dados RefSeq ${ }^{8}$, na plataforma NCBI e alinhamos as sequências de cada espécie por meio do programa Clustal Omega (EMBL-EBI) (http://www.ebi.ac.uk/Tools/msa/clustalo/). Os aminoácidos que se mantiveram conservados, principalmente a partir dos vertebrados (que é composto por animais com sistema nervoso central bem definido), foram considerados importantes para a função das proteínas no sistema nervoso central.

\subsubsection{Domínios e regiões estruturais afetadas}

A análise de domínios e regiões estruturais proteicas afetadas foi baseada na literatura e a partir das informações disponíveis sobre cada proteína nos bancos de dados $\mathrm{NCBI}^{9}$, Ensembl ${ }^{10}$ e UniProt ${ }^{11}$.

\subsubsection{Análises in silico de predição de patogenicidade}

Para análises computacionais de predição de patogenicidade in silico utilizamos os seguintes algoritmos disponíveis na web:

> Polymorphism Phenotyping v2 (PolyPhen-2) (disponível em http://genetics.bwh.harvard.edu/pph2/). Pontuação de predição (escore): 0 - 0,15= variante benigna / 0,15 - 1= variante provavelmente prejudicial / 0,85 - 1= variante prejudicial à função proteica.

$>$ Sorting Intolerant from Tolerant $(\text { SIFT })^{12}$. Pontuação de predição (escore): 0 - 0,05 = variante afeta a função protéica / acima de 0,05= variante tolerada MutationTaster (disponível em http://www.mutationtaster.org/). Pontuação de predição (escore): 0-1 indica o grau de segurança da predição, onde 1 indica máxima concordância entre os classificadores utilizados no algoritmo.

Protein Variation Effect Analyzer (PROVEAN) (disponível em http://provean.jcvi.org/genome_submit_2.php?species=human). Pontuação de predição

\footnotetext{
${ }^{8}$ Disponível em https://www.ncbi.nlm.nih.gov/protein/

${ }^{9}$ Disponível em: https://www.ncbi.nlm.nih.gov/protein

${ }^{10}$ Disponível em: https://www.ensembl.org/index.html

${ }^{11}$ Disponível em: https://www.uniprot.org/

${ }^{12}$ Disponível em https://sift.bii.a-star.edu.sg/
} 
(escore): abaixo de $-2.5=0$ efeito da variante é prejudicial / acima de $-2.5=0$ efeito da variante é neutro.

Combined Annotation Dependent Depletion (CADD) obtido através do Variant Effect Predictor ${ }^{13}$ da plataforma Ensembl. Pontuação de predição (escore): 0-10= impacto baixo / 11-30= impacto moderado $/>30=$ impacto forte.

Tais algoritmos se baseiam em informações da proteína como conservação evolucionária, localização e consequência bioquímica do aminoácido alterado.

\subsubsection{Modelagem molecular}

Realizamos análises in silico de modelos proteicos tridimensionais para complementar as informações a respeito do efeito das variantes genéticas na estrutura e função das proteínas codificadas pelos genes investigados nesse estudo, em comparação com o modelo selvagem.

Utilizamos o método de modelagem molecular por homologia. Tal método utiliza uma proteína molde, de estrutura tridimensional elucidada experimentalmente (geralmente por cristalografia de raios $\mathrm{x}$ ), para predizer o modelo tridimensional da proteína alvo, a partir da sua sequência primária. Para tal, utilizamos o software Protein Homology / analogY Recognition Engine v2.0 (Phyre2), disponível em versão web. ${ }^{(171)}$

Phyre2 é um software que abrange um conjunto de algoritmos utilizados na predição e análise de modelos proteicos. Resumidamente, os algoritmos HHBlits e PSIPRED comparam a sequência alvo contra um banco de dados de sequências proteicas, predizendo sua estrutura secundária e combinando tanto a sequência quanto a estrutura em um modelo denominado Hidden Markov Model (HMM). Em seguida, o algoritmo HHsearch alinha esse modelo com um banco de dados HMM de estruturas já conhecidas, seguido pela modelagem das regiões de loop e adição das cadeias laterais. Os resíduos não alinhados com estruturas conhecidas são modelados através do método ab initio (modelagem baseada somente na estrutura química e sequência dos aminoácidos na proteína). ${ }^{(171)}$

\footnotetext{
${ }^{13}$ Disponível em: https://www.ensembl.org/Tools/VEP
} 
Obtivemos informações sobre a qualidade de cada modelo por meio do recurso "Phyre Investigator", disponível na mesma plataforma. ${ }^{(171)}$ Nesse recurso, o algoritmo ProQ2 ${ }^{(172)}$ e a análise do plot Ramachandran avaliaram a qualidade global do modelo proteico, indicando resíduos modelados inadequadamente baseado nas angulações moleculares phi/psi da estrutura. Outros algoritmos avaliaram regiões de choque (clashes) entre resíduos muito próximos e regiões de rotâmeros, a fim de indicar cadeias laterais dispostas inadequadamente, estrutura incorreta e erros de alinhamento. Além disso, através do algoritmo Disopred, ${ }^{(173)}$ foi possível avaliar regiões desordenadas dos modelos, correspondentes às regiões dinâmicas e flexíveis da proteína (distintas das regiões de loop) e que podem se alterar mediante condições experimentais cristalográficas. Do ponto de vista funcional, através do programa fpocket2, ${ }^{(174)}$ avaliamos regiões de "pocket" (bolsões), indicativos de sítios e domínios de interação dos modelos com outras proteínas ou moléculas.

Por fim, utilizamos o software 3DLigandSite para a predição de sítios de ligação(175) e o programa UCSF Chimera $1.13^{14}$ para visualizar e analisar os modelos. Nós analisamos os efeitos estruturais e funcionais causados pelas variantes considerando a perda ou aquisição de pontes de hidrogênio e sítios de ligação e alterações nas regiões de loop ou domínios de interação molecular.

\subsubsection{Análise de segregação familiar}

Quando disponível, investigamos as variantes identificadas em familiares dos probandos a fim de verificar se o genótipo segregou entre os membros afetados (quando há história familiar positiva) ou se estava ausente em membros não afetados.

\subsubsection{Correlações genótipo-fenótipo}

Correlacionamos as informações clínicas dos indivíduos portadores de variantes potencialmente patogênicas (obtidas no recrutamento e anamnese) com dados reportados por outros estudos.

\footnotetext{
${ }^{14}$ Disponível em https://www.cgl.ucsf.edu/chimera/download.html
} 
Os dados fenotípicos incluem: sexo (masculino, feminino); consanguinidade (sim, não); local de surgimento dos sintomas; locais de distribuição dos sintomas; idade de surgimento dos sintomas; duração da distonia (em anos); resposta em tratamentos específicos; presença de parkinsonismo ou mioclonia; padrão temporal específico e história familiar (positiva, possível, negativa, desconhecida). Consideramos "possível" quando o probando afirma história familiar positiva, mas os familiares não estavam disponíveis para avaliação clínica. Outras características, sinais e sintomas também foram considerados quando pertinentes. 
3 RESULTADOS

\subsection{Participantes}

Foram incluídos nesse estudo, 153 indivíduos com distonia idiopática (isolada ou combinada), recrutados em todas as faixas etárias (entre 2 e 84 anos de idade). As características clínicas desses probandos estão detalhadas na tabela 1.

Tabela 1. Características clínicas dos probandos incluídos nesse estudo

\begin{tabular}{lcc}
\hline Características clínicas & $\mathbf{n}(\%)$ & Variação \\
\hline Sexo & $56(36,6)$ \\
Masculino & $97(63,4)$ \\
Feminino & \\
História familiar de distonia & $15(9,8)$ \\
Positiva & $115(75,1)$ \\
Negativa & $18(11,8)$ \\
Possível & $5(3,3)$ \\
Desconhecida & \\
Idade de início dos sintomas & $5(3,3)$ \\
Primeira infância (<2 anos) & $35(22,9)$ \\
Segunda infância (3-12 anos) & $26(17,0)$ \\
Adolescência (13-20 anos) & $41(26,8)$ \\
Fase adulta inicial (21-40 anos) & $46(30,0)$ \\
Fase adulta tardia (>40 anos) & \\
Distribuição corporal dos sintomas & $56(36,6)$ \\
Focal & $12(7,9)$ \\
Multifocal & $51(33,3)$ \\
Segmentar & $34(22,2)$ \\
Generalizada & \\
Parkinsonismo anos & \\
Sim & $5(3,2)$ \\
Mioclonia & $5(3,2)$ \\
Sim & \\
* n (número de indivíduos) / \% (Frequência relativa). Número total de probandos N=153.
\end{tabular}

Selecionamos um total de 144 amostras do grupo controle (conforme detalhado no item 2.2) para comparação da frequência alélica das variantes identificadas. Considerando que nem todas as amostras testadas funcionaram na primeira reação de sequenciamento (seja por limitações ou falhas técnicas e até mesmo pela qualidade do material genômico de algumas amostras), consideramos 
satisfatório um total de controles entre o mínimo proposto no projeto e o total investigado (entre 101 e 144 amostras), a fim de respeitar a quantidade de reagentes. Tal abordagem foi realizada na análise de dois dos treze genes (TUBB4A e PRKRA) e, posteriormente, a partir do início de 2018 , passamos a utilizar bancos de dados genéticos brasileiros compostos por exomas representativos da população brasileira como o BipMed-WES (composto por 106 exomas) e o ABraOm (composto de 609 exomas). ${ }^{(161,162)}$

\subsection{Análise genética: sequenciamento}

Todas as amostras de DNAg foram extraídas de células nucleadas do sangue periférico. A concentração de DNA nas amostras variou entre 41,5 e $1078,0 \mathrm{ng} / \mu \mathrm{L}$, e todas apresentaram boa qualidade conforme razão de absorbância 260/280 em aproximadamente 1,8. Para sequenciamento, as concentrações foram normalizadas em $25 \mathrm{ng} / \mu \mathrm{L}$.

Conforme as características do nosso estudo e as especificações do fabricante, obtivemos um painel composto por 229 amplicons para cada amostra (com tamanho total de 425 pares de base), sequenciados nos dois sentidos da fita de DNA (paired-end) e com uma cobertura aproximada de 1250x para cada fragmento.

O painel abrangeu $95 \%$ das regiões selecionadas. Os outros $5 \%$ corresponderam às 13 regiões de gaps (regiões não cobertas pelos amplicons), que somadas totalizaram 3.028 pares de base. As regiões dos gaps foram mapeadas e estão descritas no quadro 3. Tais regiões foram analisadas em casos específicos, nos probandos com história familiar positiva e/ou fenótipo indicativo de causa genética.

O processo de construção das bibliotecas ocorreu conforme esperado, segundo análise por eletroforese em gel de agarose. As amostras de dois probandos foram excluídas do grupo amostral por falha na construção das respectivas bibliotecas (probandos já excluídos do grupo amostral descrito na tabela 1). Os processos de clusterização e sequenciamento também ocorreram conforme esperado.

Após a reação de sequenciamento e identificação das bases, somente aquelas com a chance de erro de 1:1000 (ou seja, acurácia de 99.9\%) foram consideras no alinhamento (conforme filtragem para escore Phred, mínimo de qualidade Q30). 
Quadro 3. Mapeamento das regiões não sequenciadas pelo painel (gaps)

\begin{tabular}{|c|c|c|c|}
\hline GAP ID & Gene & Região & Abrangência* \\
\hline 261280 & $\mathrm{GCH} 1$ & Éxon 4 & Total $(82 / 82)$ \\
\hline 261289 & ATP1A3 & Éxon 4 & Total (224/224) \\
\hline 261288 & ATP1A3 & Éxon 8 & Total (289/289) \\
\hline 261287 & ATP1A3 & Éxon 17 & Parcial (23/175) \\
\hline 261282 & PRKRA & Éxon 6 & Total $(115 / 115)$ \\
\hline 261290 & $C l Z 1$ & Éxon 8 & Parcial (396/727) \\
\hline 261281 & ANO3 & Éxon 24 & Total $(173 / 173)$ \\
\hline 261285 & GNAL & Éxon 4 & Parcial (27/140) \\
\hline 261291 & GNAL & $3^{\prime} \cup T R^{* *}$ & - \\
\hline 261292 & GNAL & $3^{\prime} \cup T R^{* *}$ & - \\
\hline 261293 & GNAL & $3^{\prime} \cup T R^{* *}$ & - \\
\hline 261283 & $D D C$ & Éxon 6 & Total $(164 / 164)$ \\
\hline 261284 & $D D C$ & Éxon 15 & Parcial (95/428) \\
\hline
\end{tabular}

\subsection{Variantes genéticas identificadas}

\subsubsection{Variantes priorizadas e validadas}

Após alinhamento e anotação, variantes do tipo sinônimas, classificadas como benignas ou frequentes em bancos de dados populacionais (frequência acima de 1\% na população geral), foram filtradas e desconsideradas das análises posteriores. Foram priorizadas variantes em regiões de emenda éxon-íntron, não sinônimas, deleções e inserções.

Com exceção de uma variante no gene $A N O 3$, todas as variantes foram confirmadas e validadas pelo método de sequenciamento Sanger. Na tabela 2, estão descritas as 21 variantes priorizadas e validadas. 
Tabela 2. Variantes genéticas priorizadas e validadas

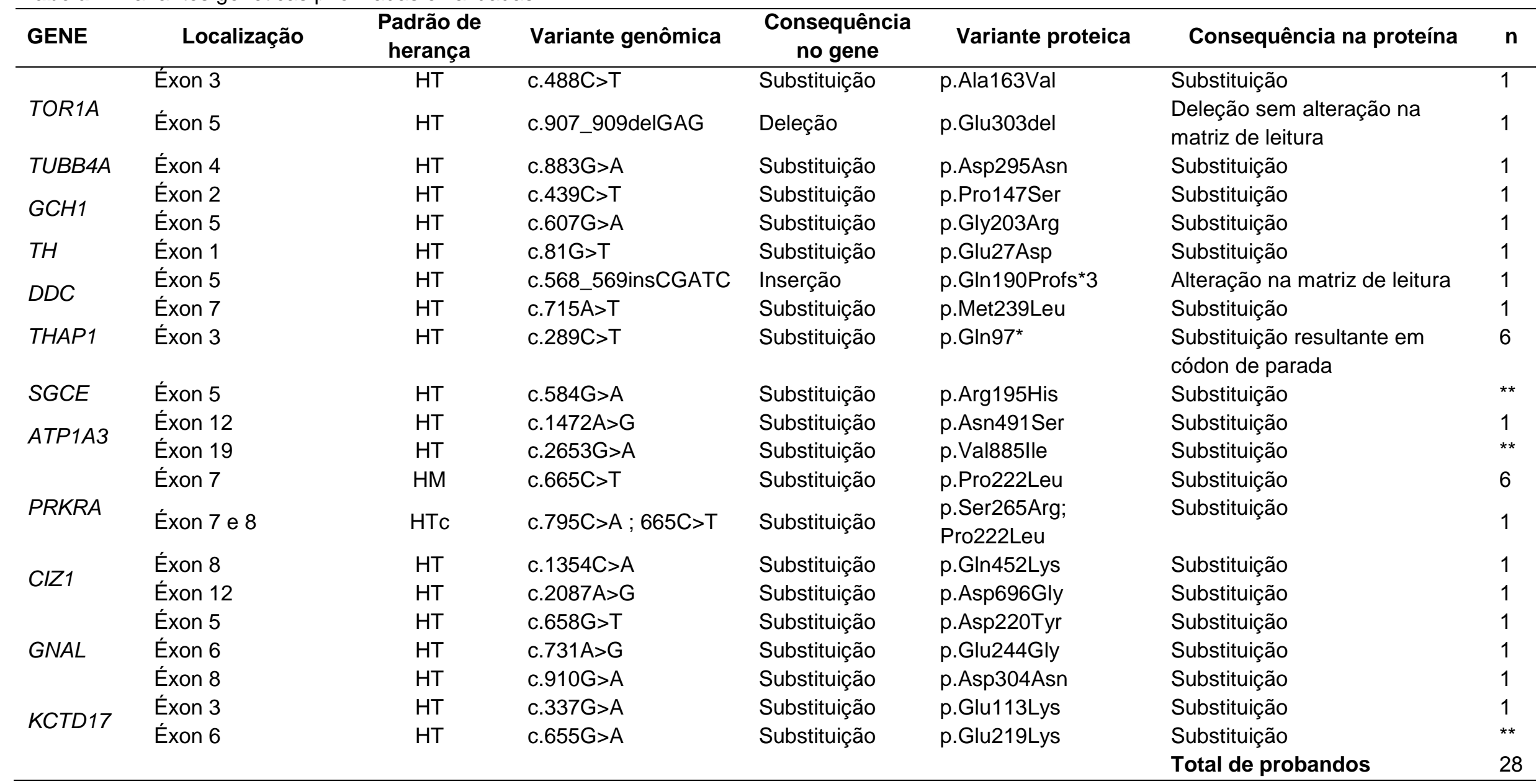

$\mathrm{N}$ (quantidade de probandos afetados pela variante). HT (Heterozigoto). HM (Homozigoto). HTc (Heterozigoto composto). ${ }^{* \star}$ probandos que possuem variante em outro gene e já foram contabilizados no total. 


\subsubsection{Achados secundários}

Ao sequenciar as regiões cobertas pelos amplicons no gene GNAL, identificamos variantes em um outro gene, que não estava relacionado no painel customizado e nem está relacionado com distonia. Os genes MPPE1 e GNAL se sobrepõem parcialmente na região do cromossomo 18p11.21, e ao cobrir o gene GNAL, os amplicons abrangeram os dois últimos éxons do gene MPPE1, nos quais identificamos as variantes c.911C>T (p.Thr304Met), c.1189T>A (p.*397Arg) e c.1022C>A (p.Pro341His) em 4 probandos. Para verificar a relação de variantes nesse gene com distonia, investigamos todos os éxons do gene MPPE1 em todos os indivíduos com história familiar positiva ou possível do banco de amostras da RBED $(n=41)$ por meio de sequenciamento Sanger. Somente uma variante c.413G $>A$ (p.Arg138GIn) foi identificada no éxon 5 de um probando.

\subsection{Potencial patológico das variantes}

À nível genômico, das 21 variantes priorizadas e validadas, 19 são substituições de um único nucleotídeo, enquanto as outras duas correspondem à uma deleção e uma inserção (Tabela 2). A seguir, estão detalhados os resultados das análises de patogenicidade de cada variante identificada.

\subsubsection{TOR1A}

c.488 C>T (p.Ala163Val): A substituição do nucleotídeo citosina (C) por timina / uracila (T/U) na posição 488 do RNA mensageiro (RNAm), em heterozigose, resulta na troca da trinca GCG por GUG, alterando o aminoácido alanina (Ala) por valina (Val) na posição 163, durante o processo de tradução da proteína torsina 1A. Ambos os aminoácidos envolvidos possuem carga neutra, são apolares e diferem pouco no tamanho (Ala 71,09Da e Val 99,14Da). A variante p.Ala163Val já estava descrita nos bancos de dados gnomAD (0,03\%) e ABraOM (0,08\%) e está classificada como "variante de significado incerto" segundo o ClinVar (rs142909469). As análises de patogenicidade in silico preditas por cada algoritmo foram: 
provavelmente prejudicial (Polyphen2, escore 0.595), tolerada (SIFT, escore 0.118), polimorfismo (MutationTaster, escore 0.99), neutra (PROVEAN, escore -2.07) e variante de efeito moderado (CADD, escore 23).

c.907_909delGAG (p.Glu303del): Essa variante leva à deleção de 3 nucleotídeos, ocasionando a perda de um aminoácido glutamato (Glu) na posição 303 da proteína torsina $1 \mathrm{~A}$. A deleção desse único aminoácido não altera a matriz de leitura da proteína (Figura 11). Está classificada como "patogênica" tanto no banco de dados ClinVar (rs80358233) quanto no banco de dados LOVD e está descrita no gnomAD com frequência de $0,01 \%$. Uma vez que nem todos os algoritmos in silico analisam variantes indel, somente três dos algoritmos foram utilizados, os quais resultaram em: variante causadora de doença (MutationTaster, escore 0.99), prejudicial (PROVEAN, escore -10.26) e de impacto moderado (CADD, escore 22.5). Além disso, essa variante foi confirmada na irmã sintomática do probando.

Segundo o recurso Homologene, dentro do reino animal, o gene TOR1A é conservado em animais Bilateria (animais que possuem simetria bilateral) e possui ortólogos em todas as espécies selecionadas. A alanina na posição 163 se manteve conservada em mamíferos e está localizada em uma região de interação com a proteína SNAPIN, enquanto o glutamato na posição 303 se manteve conservado entre tetrápodes (animais terrestres que possuem quatro membros) e está localizado em uma região de interação com a proteína KLC1 (Figura 11).

Em relação à modelagem molecular in silico, obtivemos modelos da proteína torsina $1 \mathrm{~A}$ selvagem e modelos com as variantes identificadas nesse estudo (p.Ala163Val e p.Glu303del). Além disso, geramos um modelo com a variante p.Asp216His, que é a mais frequente no banco de dados gnomAD (frequência de 12\%) e aparentemente benigna, segundo classificação do banco de dados ClinVar.

A estrutura molde selecionada em todos os modelos foi a c5j1sA, correspondente à proteína torsina $1 \mathrm{~A}$ humana em complexo com a proteína LULL1, elucidada por meio de cristalografia de raios $x$ (com resolução de 1.399Å). Em todos os modelos, $83 \%$ dos resíduos foram modelados com mais de $90 \%$ de confiança e se mostraram adequados segundo análises de qualidade, sem regiões de choque (clashes) e rotâmeros. Nenhum dos resíduos variantes estavam em regiões desordenadas dos modelos. 
TOR1A

c.488 C>T (HT)

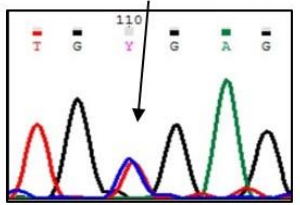

p.Ala163Val

NVSACARS

NVSACARS

NVSACARS

NVSACARS

NVSACARS

NVSACARS

NVSACARS

NVSICPRS

NVSNCERS

NVSICPRS

TLRSCPRS

- -AKCPNA

TVQKCQRS

Região de interação com SNAPIN
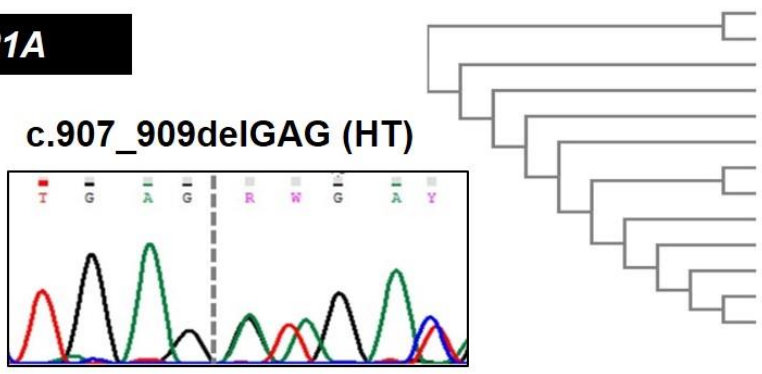

NP 572178.10 .302941 XP_310142.4 0.302941 A. gambiae NP_495916.1 0.331164 C. elegans NP_001186944.1 0.223158 $\quad$ D. rerio NP_001016237.1 0.199326 X. tropicalis NP_001025858.1 0.144711 G. gallus NP_659133.1 $0.0165165 \quad$ M.musculus $\begin{array}{ll}\text { NP_695215.2 0.0165165 R. norvegicus } & \text { R. }\end{array}$ NP_001092528.10.0349738 $\quad$ B. taurus XP_548417.3 0.033509 C. lupus $\begin{array}{ll}\text { XP_548417.3 0.033509 } & \text { C. lupus } \\ \text { XP_014972073.1 0.0106994 } & \text { M. mulatta }\end{array}$ NP_000104.1 0.00150602 $\quad$ H. sapiens XP_001164380.2 0.00150602 P. troglodytes

No gene TOR1A, os eletroferogramas ilustram a variante c.488C $>\mathrm{T}$ com a troca de um nucleotídeo citosina (pico azul) por timina (pico vermelho) em heterozigose, e a variante c.907_909delGAG com despareamento dos picos após deleção. Abaixo, alinhamento da sequência proteica entre diversas espécies, agrupadas conforme grupos taxonômicos, demonstra conservação do aminoácido alanina (A) na posição 163 entre vertebrados e do glutamato $(E)$ na posição 303 entre tetrápodes.

Figura 11. Variantes no gene TOR1A

As sequências primárias da proteína torsina $1 \mathrm{~A}$, que foram submetidas ao processo de modelagem molecular, correspondiam à estrutura completa da proteína, com uma sequência sinalizadora voltada para a face externa da membrana (resíduos 1-20), seguida por resíduos altamente hidrofóbicos de ancoragem à face interna da membrana (resíduos 21-40) (Figura 12). Já a proteína molde (c5j1sA) correspondeu à estrutura madura da proteína torsina $1 \mathrm{~A}$, onde a sequência sinalizadora estava ausente, condizente com seu estado no momento da cristalização (em complexo com seu ativador LULL1). Portanto, a região de completa homologia com a proteína molde foi do resíduo 55 ao 302 (com mais de 90\% de confiança), enquanto os resíduos iniciais (1 ao 55) foram modelados pela abordagem ab initio. 
A)

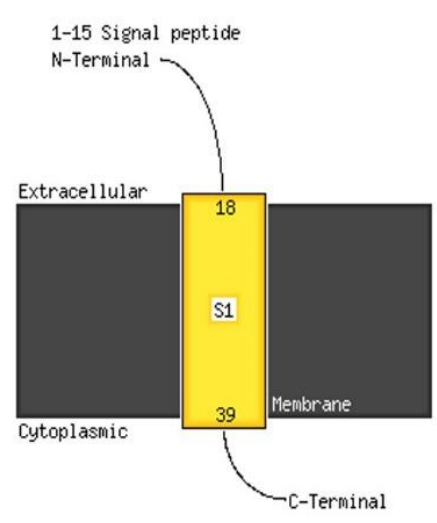

B)

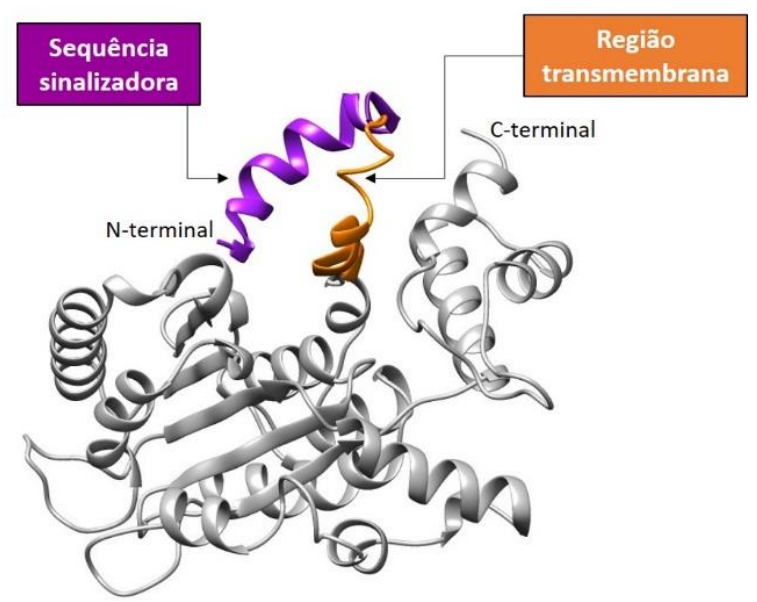

A) Figura gerada pela plataforma Phyre2 indicando a região transmembrana com sequência sinalizadora (N-terminal) voltada para a face externa. B) Estrutura terciária da proteína torsina $1 \mathrm{~A}$, com a sequência sinalizadora (roxo) e a região transmembrana (laranja) destacadas.

Figura 12. Sequência sinalizadora e região transmembrana da proteína torsina $1 \mathrm{~A}$

$\mathrm{Na}$ figura 13 estão destacadas as regiões da proteína torsina $1 \mathrm{~A}$ que interagem com as proteínas KLC1, SNAPIN e SYNE3. Tais regiões podem sofrer alterações conformacionais, ficando mais expostas mediante ativação por moléculas de ATP. Os sítios de ligação de ATP preditos pelo algoritmo 3DLigandSite corresponderam aos sítios já descritos nos bancos de dados do NCBI e UniProt. Nos modelos gerados, esses sítios de ligação de ATP (incluindo os motivos Walker) assumiram a conformação de um poro centralizado na proteína, correspondente com a região de bolsão (pocket) predita (Figura 14). Ademais, no modelo selvagem foram preditos sítios de interação com magnésio (resíduos 109, 135, 208 e 241) e zinco (resíduos 54 e 117-121).

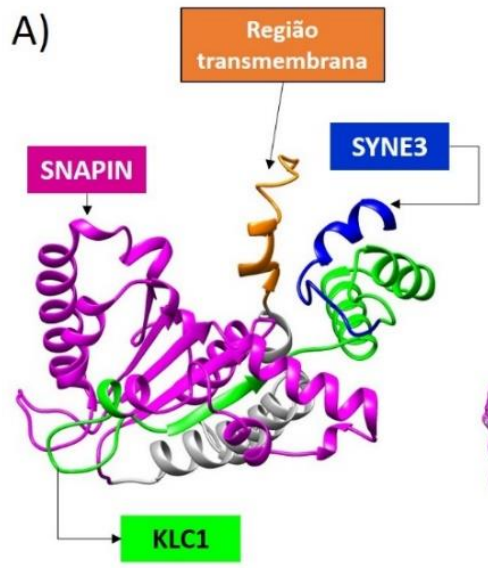

B)

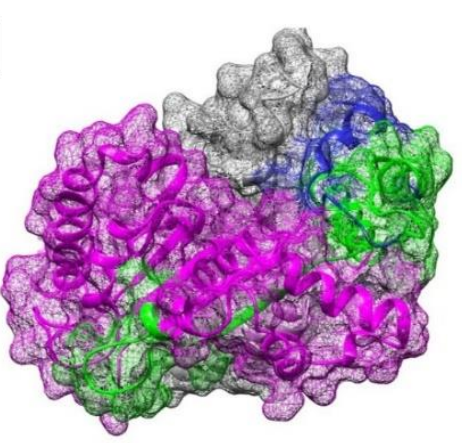

C)

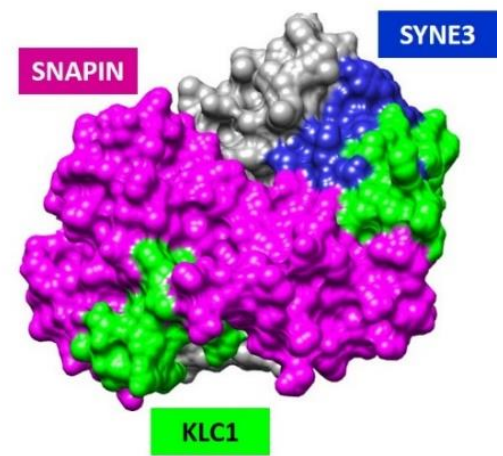

A) Estrutura do modelo selvagem em fita demonstrando a região transmembrana (laranja), as regiões de interação com a proteína SNAPIN (magenta), KLC1 (verde) e SYNE3 (azul). B) Estrutura da proteína torsina $1 \mathrm{~A}$ em superfície mesclado com fita e $\mathrm{C}$ ) estrutura em superfície.

Figura 13. Regiões de interação proteica da proteína torsina $1 \mathrm{~A}$ 


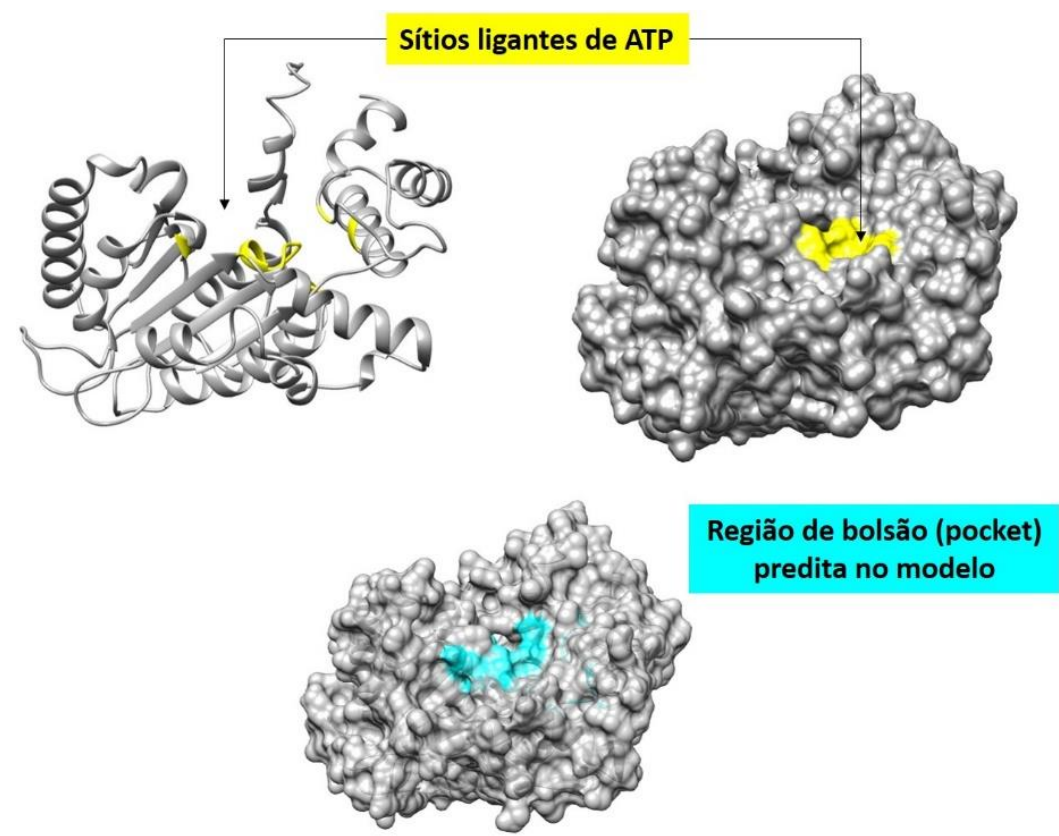

Figura 14. Sítios de ligação de ATP preditos nos modelos da proteína torsina $1 \mathrm{~A}$

As posições dos resíduos A163 (na região de interação com SNAPIN) e E303 (na região de interação com KLC1) estão ilustradas na figura 15.
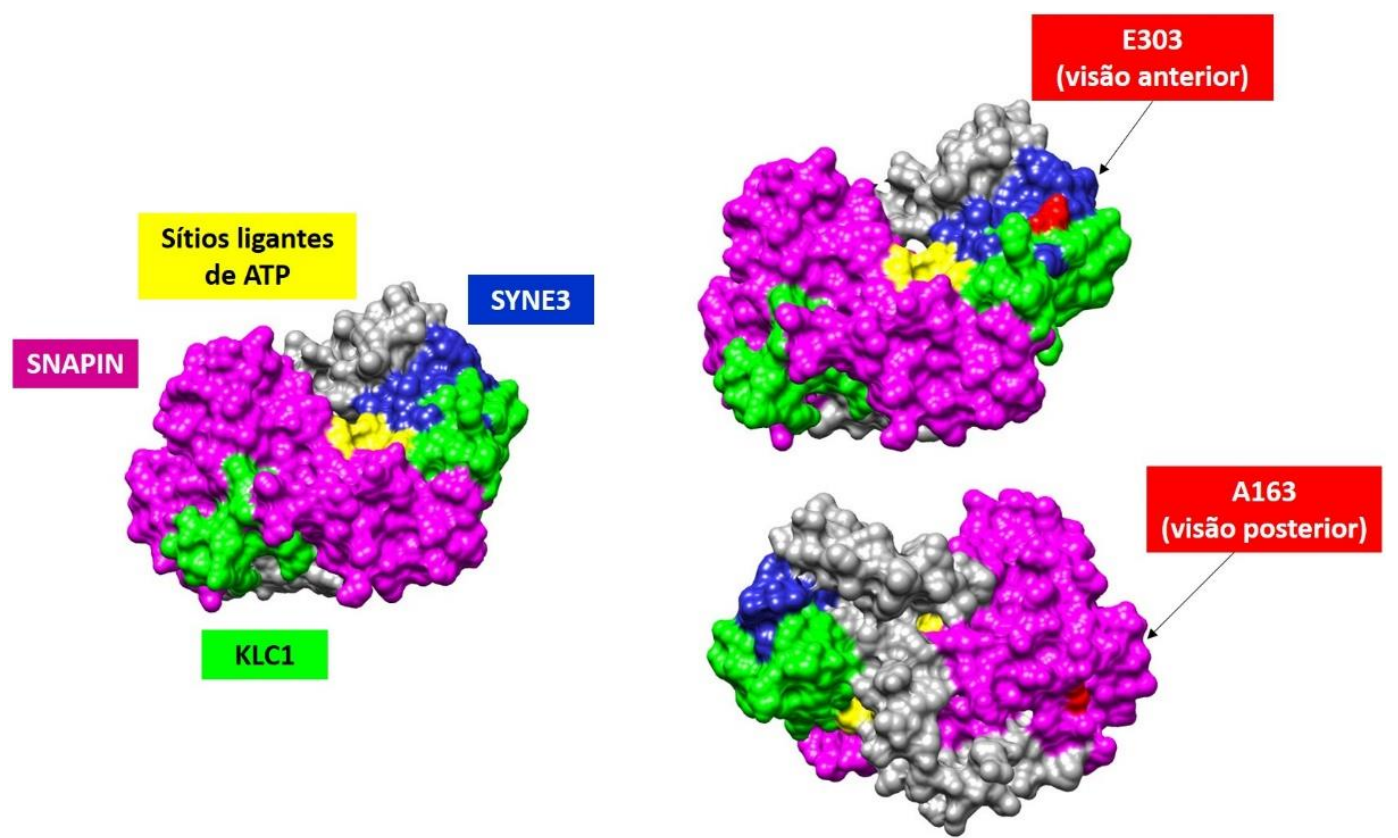

À esquerda está a estrutura da proteína torsina $1 \mathrm{~A}$ em superfície com as regiões de interação destacadas: interação com SNAPIN (magenta), com KLC1 (verde), com SYNE3 (azul) e com ATP (amarelo). À direita estão os mesmos modelos com as variantes ilustradas em vermelho. Glutamato (E), Alanina (A).

Figura 15. Posição das variantes nos modelos proteicos da torsina $1 \mathrm{~A}$ 
De modo geral, em relação ao modelo selvagem, o modelo variante p.A163V perdeu 17 pontes de hidrogênio e o modelo p.E303del perdeu 36, enquanto o modelo com a variante benigna não perdeu nenhuma. Para essa análise, foram considerados somente as pontes estabelecidas entre os resíduos modelados por homologia com a proteína molde (resíduos SER55-ASP331), e os resíduos modelados pela abordagem ab initio foram desconsiderados devido ao baixo valor de confiança.

$\mathrm{Na}$ posição 163 da cadeia polipeptídica, nem o aminoácido selvagem (alanina) e nem o aminoácido variante (valina) possuem pontes de hidrogênio com outros resíduos da proteína. Porém, essa variante desencadeou alterações nas interações e ligações dos resíduos adjacentes, segundo o modelo variante. O resíduo CYS162 adquiriu uma ponte de hidrogênio com sua própria cadeia lateral e mais três pontes de hidrogênio entre sua cadeia lateral e os resíduos SER165, VAL159 e ASN158. A ligação do resíduo ALA161 com o GLY157 foi alterada para o resíduo ASN158 (Figura 16A) e a cadeia lateral do resíduo SER160 ganhou uma ponte de hidrogênio com o resíduo ARG156 (Figura 16B). A cadeia lateral do resíduo ARG164, que se ligava ao resíduo ASN89, passou a se ligar ao resíduo ILE87 e o resíduo ILE166 perdeu uma ligação com o resíduo TYR128 (Figuras 16C e D). 

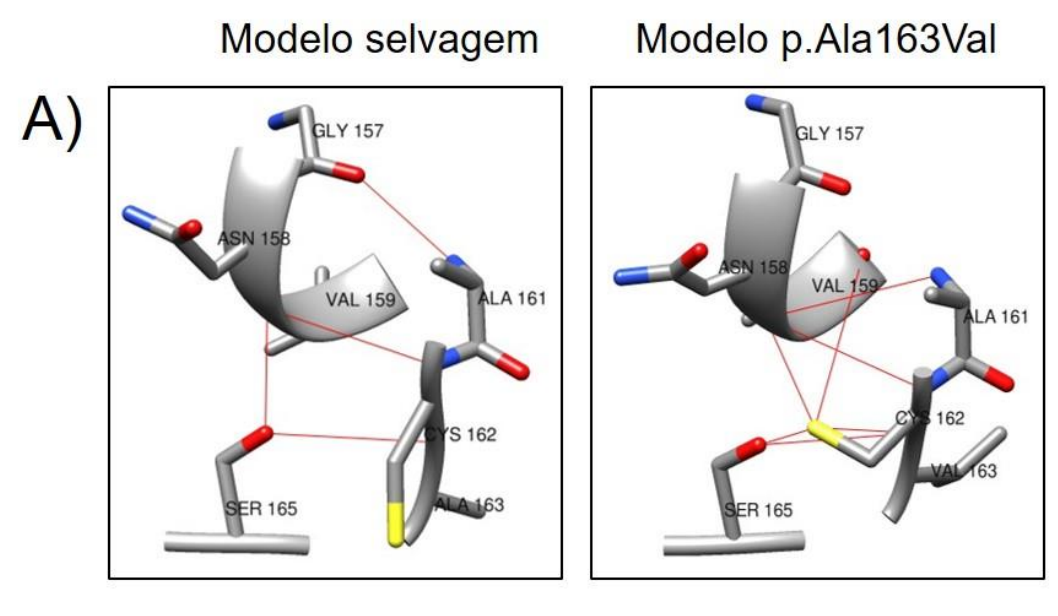

B)
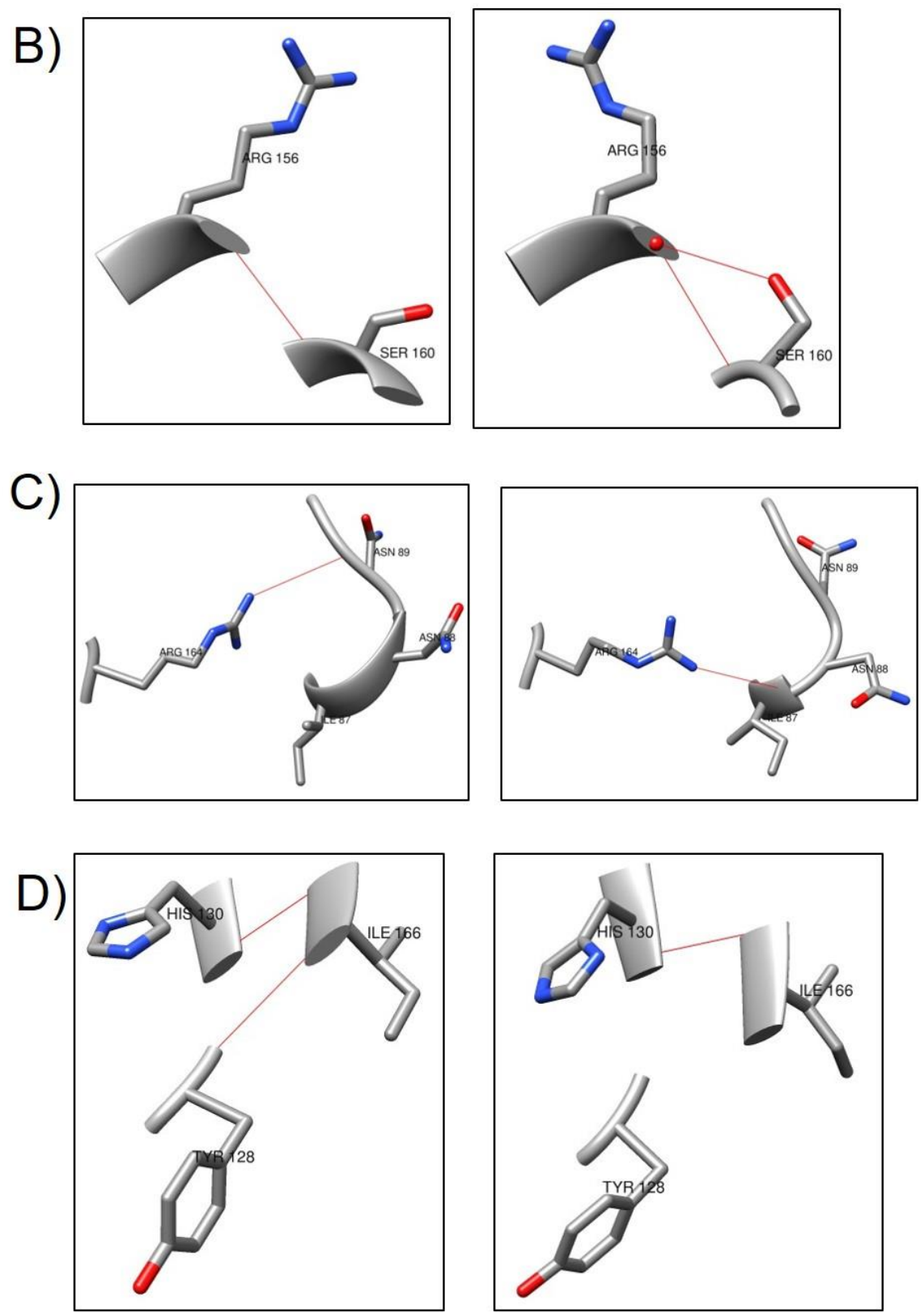

As linhas em vermelho representam as pontes de hidrogênio estabelecidas entre os resíduos (cinza) e suas cadeias laterais.

Figura 16. Alterações nas interações entre os resíduos adjacentes à variante p.Ala163Val no gene TOR1A 
Já a deleção do glutamato na posição 303 levou ao encurtamento da a-hélice 17 do modelo, devido à perda de duas pontes de hidrogênio, estabelecidas entre o resíduo E303 e os resíduos R299 e V300. Uma ponte de hidrogênio estabelecida entre a cadeia lateral do resíduo E303 e o resíduo Y329 também foi perdida, afetando a interação entre as duas últimas a-hélices do modelo (Figura 17). Essas a-hélices (17 e 18) são responsáveis pela interação com a proteína SYNE3. Além disso, o aminoácido metionina (Met) (que passou a ocupar a posição E303 após deleção) adquiriu uma ponte de hidrogênio com o resíduo S315, a fim de compensar a perda de 4 pontes de hidrogênio que estabilizavam essa região de loop no modelo selvagem (Figura 17).

Modelo selvagem

A)

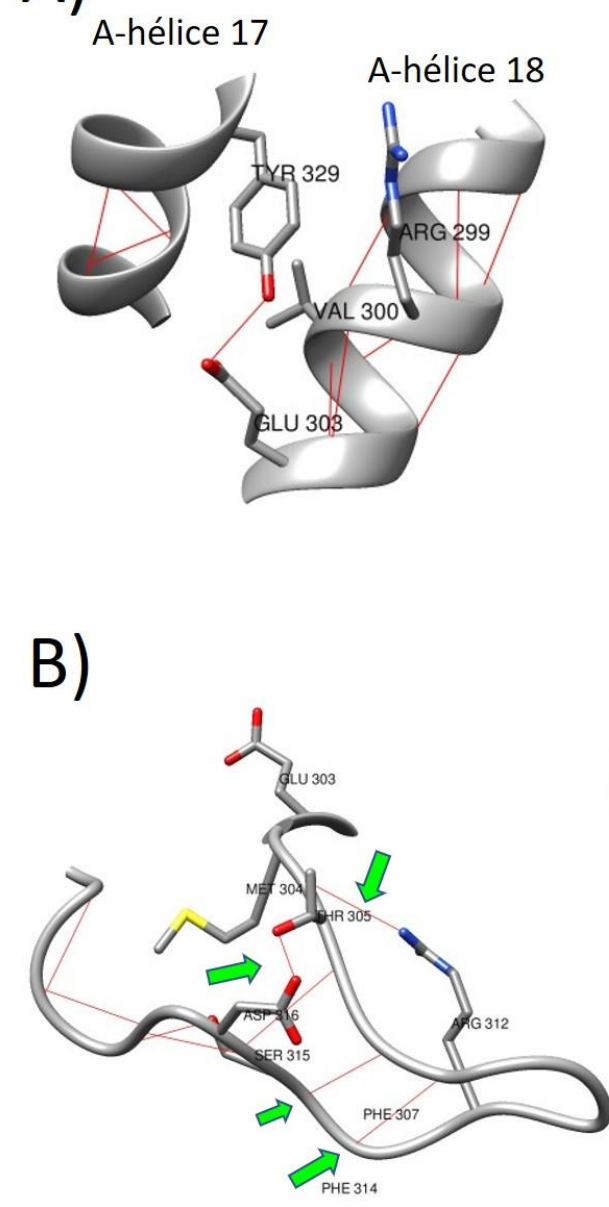

Modelo p.E303del

\section{A-hélice 17}
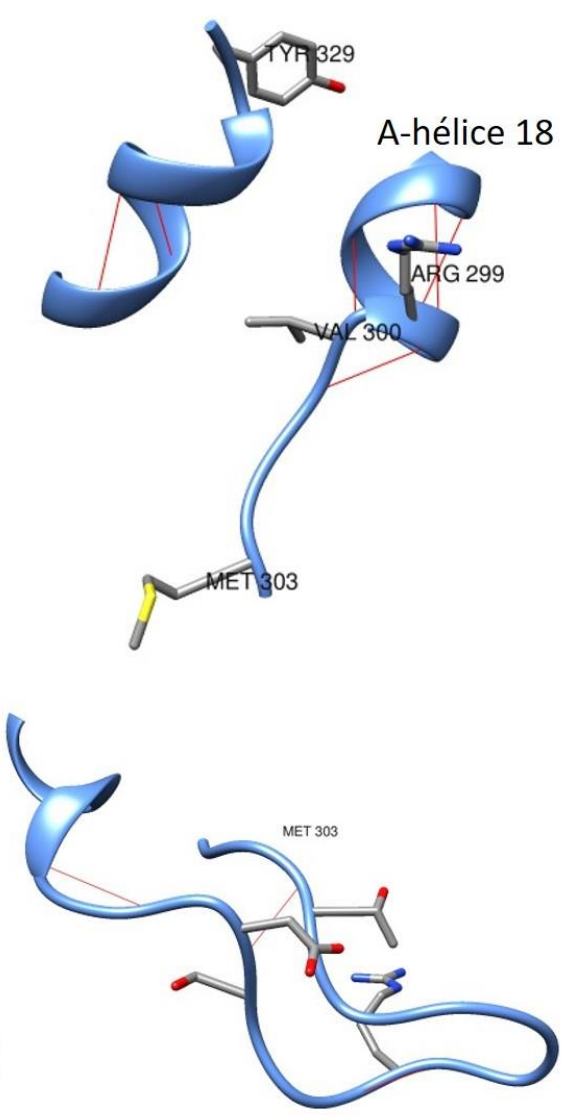

As linhas em vermelho representam as pontes de hidrogênio estabelecidas entre os resíduos (cinza) e suas cadeias laterais.

Figura 17. Alterações nas interações entre os resíduos no modelo com a variante p.Glu303del no gene TOR1A 


\subsubsection{TUBB4A}

c.883G>A:(p.Asp295Asn). A substituição do nucleotídeo guanina (G) por adenina (A) na posição 883 do RNAm, em heterozigose, resulta na troca da trinca GAU por AAU, alterando o aminoácido aspartato (Asp) por um asparagina (Asn) na posição 295, durante o processo de tradução da proteína $\beta$-tubulina 4A. Apesar de ser conservada em eucariotos (Figura 18), não identificamos proteínas ortólogas à tubulina 4A em nenhuma espécie da categoria "aves”, somente a proteína $\beta$-tubulina 4B (TUBB4B), na qual o aspartato na posição 295 se manteve conservado (NM_001080860.2 - Gallus gallus). Tanto o Asp quanto o Asn são aminoácidos polares de tamanho aproximado (115,09 $\mathrm{Da}$ e $114,11 \mathrm{Da})$ e diferem nas cargas atribuídas às suas cadeias laterais, negativa no Asp e neutra no Asn.

\section{TUBB4A}

\section{c.883 G>A (HT)}

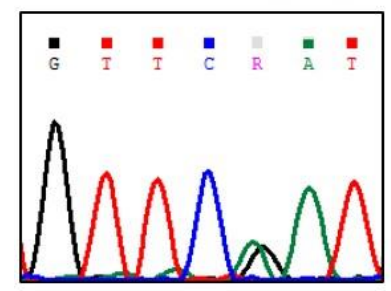

p.Asp295Asn

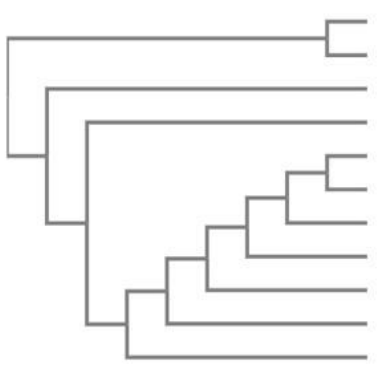

NP_523842.2 0.0242291 XP_314483.4 0.0242291 XP_001119010.2 0.0321344 NP_001070183.1 0.0123874 NP_006078.20 NP_001267357.10 XP_005633030.10 NP_001029869.10 NP_033477.20 NP_543158.10 NP 001032345.10 .0112613

Drosophila melanogaster Anopheles gambiae

Macaca mulatta Danio rerio Homo sapiens Pan troglodytes Canis lupus Bos taurus Mus musculus Rattus norvegicus Xenopus tropicalis

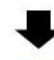

DAKNMMAAI

--- Homo sapiens

DAKNMMAAI

--- Pan troglodytes

DS------

DAKNMMAAI

--- Macaca mulatta $]$ 䒢

DAKNMMAAI

--- Canis lupus

DAKNMMAAI

--- Bos taurus

DAKNMMAAI

--- Mus musculus

DSKNMMAAI

--- Rattus norvegicus

DAKNMMAAI

--- Xenopus tropicalis

DAKNMMAAI

--- Danio rerio

DAKNMMAAI

--- Drosophila melanogaster

--- Anopheles gambiae

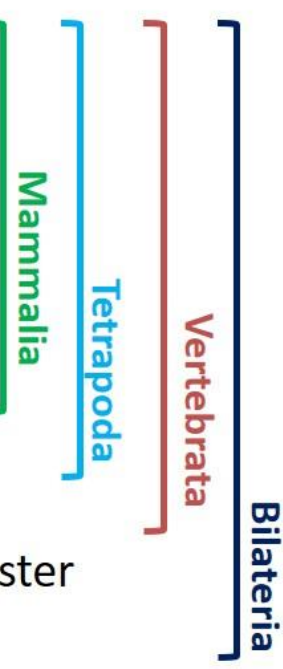

Acima está ilustrado o eletroferograma da variante c.883G $>A$, com a troca de um nucleotídeo guanina (pico preto) por adenina (pico verde) em heterozigose. Abaixo, o trecho da sequência de aminoácidos da proteína $\beta$-tubulina 4A foi alinhado com a mesma sequência de diversas espécies, demonstrando que 0 aminoácido aspartato (Asp) na posição 295 foi conservado entre as espécies na escala evolutiva.

Figura 18. Variante no gene TUBB4A 
A variante p.Asp295Asn não estava descrita em nenhum dos bancos de dados consultados. Foi predita como provavelmente prejudicial pelo algoritmo Polyphen2 (escore 0.887), prejudicial pelo algoritmo SIFT (escore 0.02), causadora de doença pelo algoritmo MutationTaster (escore 0.99), prejudicial pelo PROVEAN (escore -3.92) e de impacto moderado segundo algoritmo CADD (escore 25.9).

Identificamos essa variante no gene TUBB4A em conjunto com a variante c.2653G $>\mathrm{A}$ ( $\mathrm{p}$. Val885lle) no gene ATP1A3. Conforme demonstrado na figura 19, a variante TUBB4A foi identificada no pai, em duas tias e no irmão do probando, enquanto a variante no gene ATP1A3 foi identificada na mãe e no irmão do probando. Os familiares são assintomáticos.
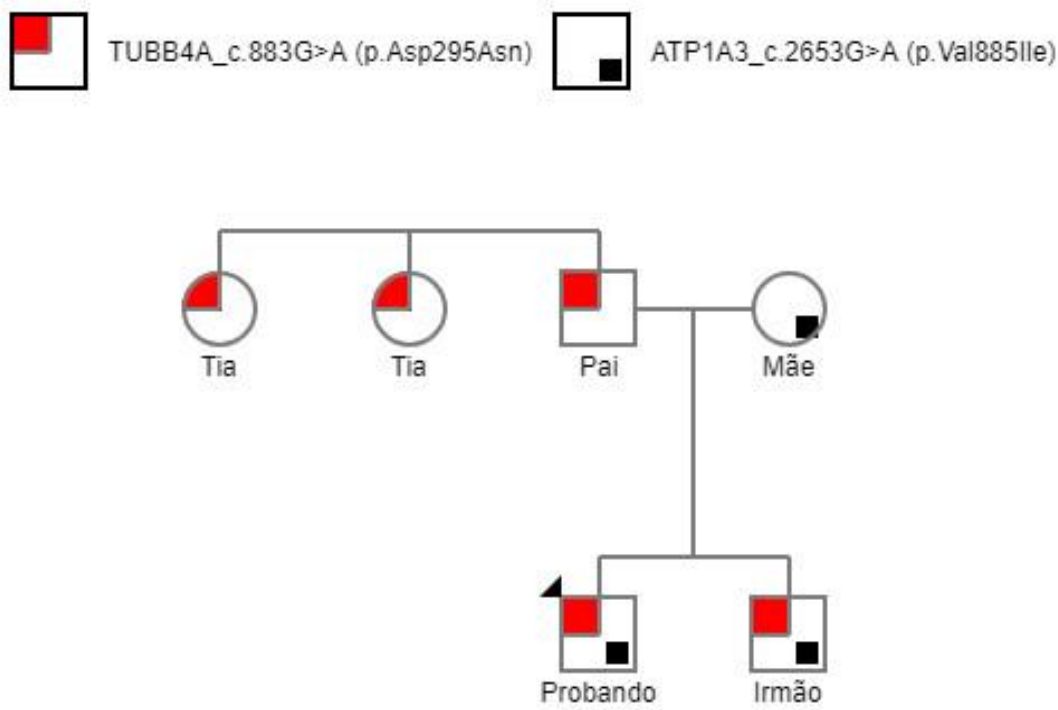

A variante TUBB4A foi herdada do pai e a ATP1A3 herdada da mãe. Tanto o probando quanto o irmão possuem as duas variantes. Nenhum dos familiares é afetado.

Fonte: Progeny Genetics [Program]. Delray Beach: Progeny Genetics LLC; c1996-2019 [cited 2019 Nov 25]. Available from: http://pedigree.progenygenetics.com/

Figura 19. Heredograma do probando TUBB4A / ATP1A3

Para análise de modelagem molecular in silico da proteína beta tubulina 4A (TUBB4A), comparamos o modelo proteico tridimensional da proteína selvagem com modelos da proteína alterados por quatro variantes: 1. p.Asp295Asn (p.D295N) - variante identificada nesse estudo; 2. p.Asp295His (p.D295H) - variante que afeta o mesmo aminoácido, e está descrita no gnomAD (rs752503674); 3. p.Arg2Gly (p.R2G) e 4. p.Ala271Thr (p.A271T) - descritas como patogênicas em distonia DYT-TUBB4A após estudo funcional. ${ }^{(66)} \mathrm{A}$ estrutura molde mais adequada selecionada foi a C2p4nB (beta-tubulina 2B, TUBB2B, Q6B856) baseado na cobertura 
(96\% de similaridade com a sequência) e confiança do modelo (100\% para os resíduos alinhados).

Tubulinas (alfa e beta) possuem três domínios funcionais: 1. Domínio N-terminal (ligante de guanosina trifosfato/guanosina difosfato (GTP/GDP)), 2. Domínio intermediário (com sítio ligante de taxol, envolvido na estabilização do microtúbulo) e 3. Domínio C-terminal (de contato entre os protofilamentos). ${ }^{(176)}$ As estruturas tridimensionais preditas foram muito semelhantes entre si, com uma região central composta por fitas $\beta$ envoltas por $\alpha$-hélices, e regiões de interação na porção lateral, superior e inferior da proteína que são essenciais para a formação dos protofilamentos do microtúbulo (Figura 20).
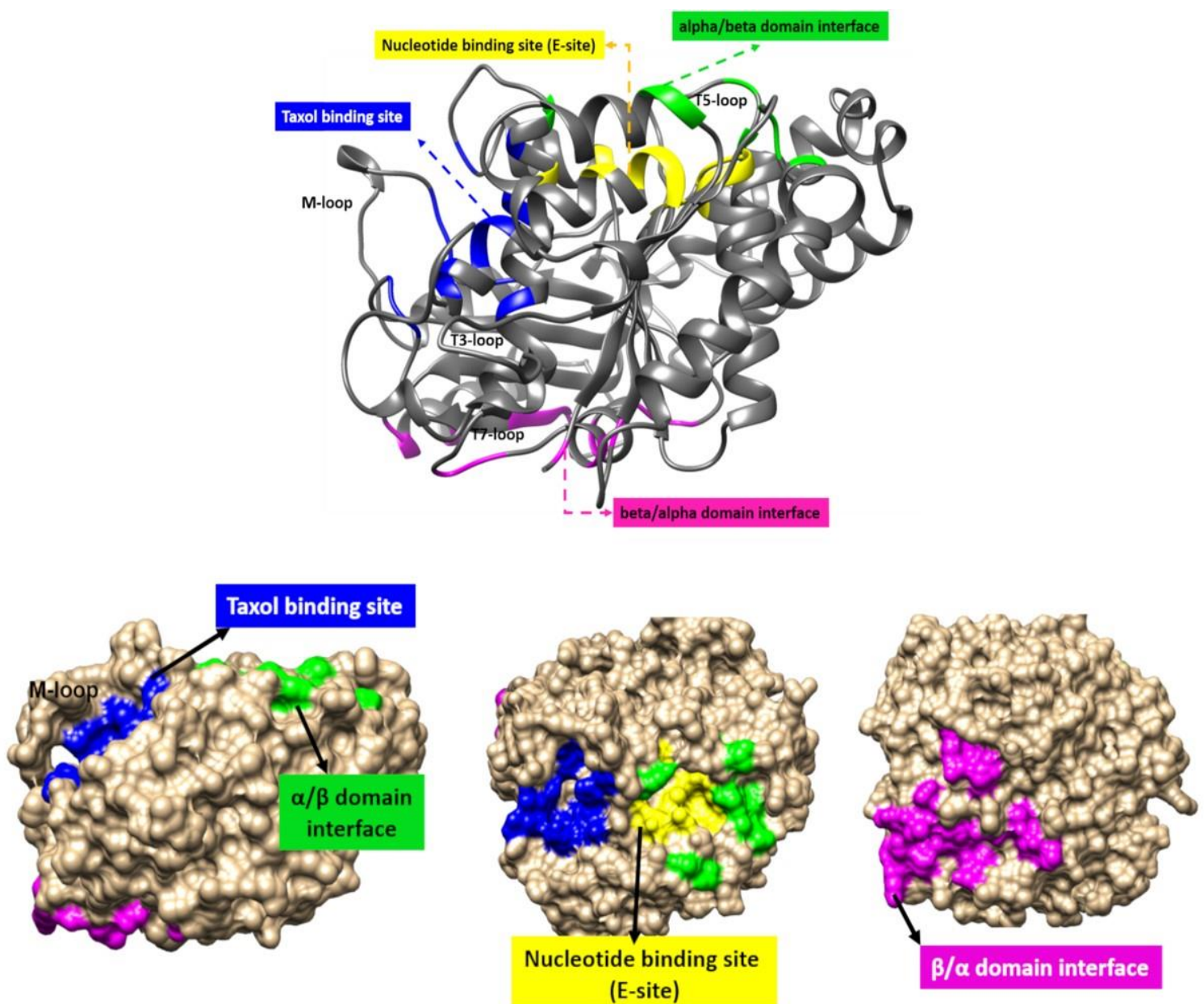

Proteína visualizada em estrutura secundária acima e em superfície abaixo (visão lateral, superior e inferior). Os domínios funcionais de TUBB4A estão destacados conforme as seguintes cores: 1. Sítio ligante de GTP/GDP (E-site) (amarelo); 2. Interface do domínio de interação entre tubulinas alfa/beta (verde); 3. Interface do domínio de interação beta/alfa (magenta); e 4. Sítio ligante de Taxol (azul).

Fonte: UCSF Resource for Biocomputing, Visualization, and Informatics. UCSF Chimera [Program]. Berkeley: National Institutes of Health; c2018 [cited 2019 Nov 25]. Available from: https://www.cgl.ucsf.edu/chimera/

Figura 20. Modelo 3D de TUBB4A baseado na estrutura C2p4nB (TUBB2B) 
Em comparação ao modelo selvagem, a substituição de um ácido aspártico (D/Asp) por uma asparagina (N/Asn) na posição 295 (p.D295N) levou à aquisição de uma ponte de hidrogênio entre os resíduos 295 e 296 (Figura 21) e à perda de uma ponte de hidrogênio entre os resíduos MET1-CYS129 e GLY132-GLU3, de interação entre os domínios proteicos. A perda da ponte de hidrogênio MET1CYS129 também foi observada no modelo R2G da variante descrita como patogênica em DYT-TUBB4A, após ensaio funcional (Figura 22). Essas alterações não foram observadas no modelo $\mathrm{D} 295 \mathrm{H}$ da variante descrita no banco de dados populacional.
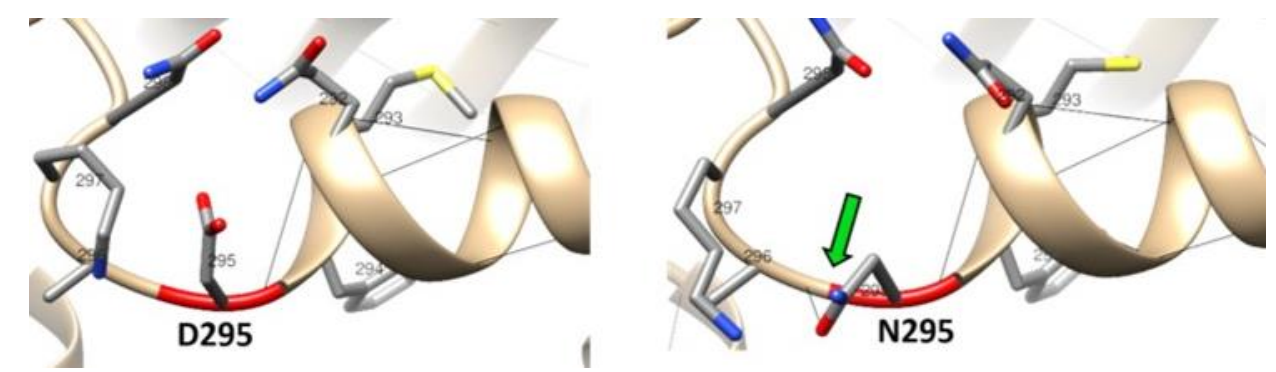

O modelo variante adquiriu uma ponte de hidrogênio entre os resíduos 295 e 296 .

Figura 21. Comparação entre o modelo TUBB4A selvagem e o variante D295N
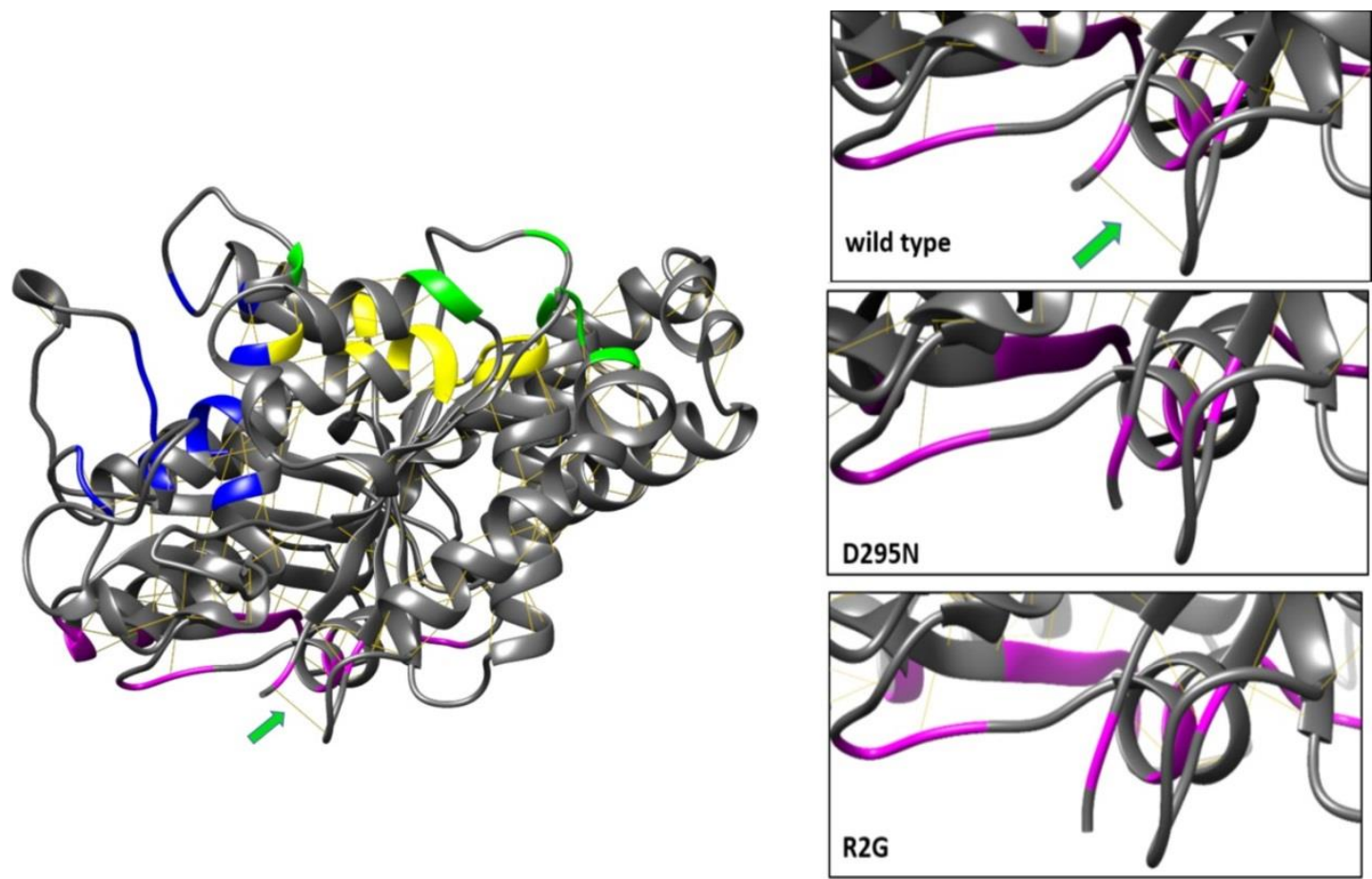

A ponte de hidrogênio entre os resíduos MET1-CYS129 indicada no modelo selvagem (acima) foi perdida nos modelos com as variantes D295N (identificada nesse estudo) e R2G (descrita como patogênica).

Figura 22. Ponte de hidrogênio de estrutura terciária perdida nos modelos TUBB4A variantes 
As regiões de loop são responsáveis pelas interações entre as tubulinas e alterações conformacionais mediante ativação e desativação mediada por GTP/GDP $^{(177,178)}$ (Figura 23). Não observamos modificações nos loops T3, T5, T7 e Mloop em nenhum dos modelos.
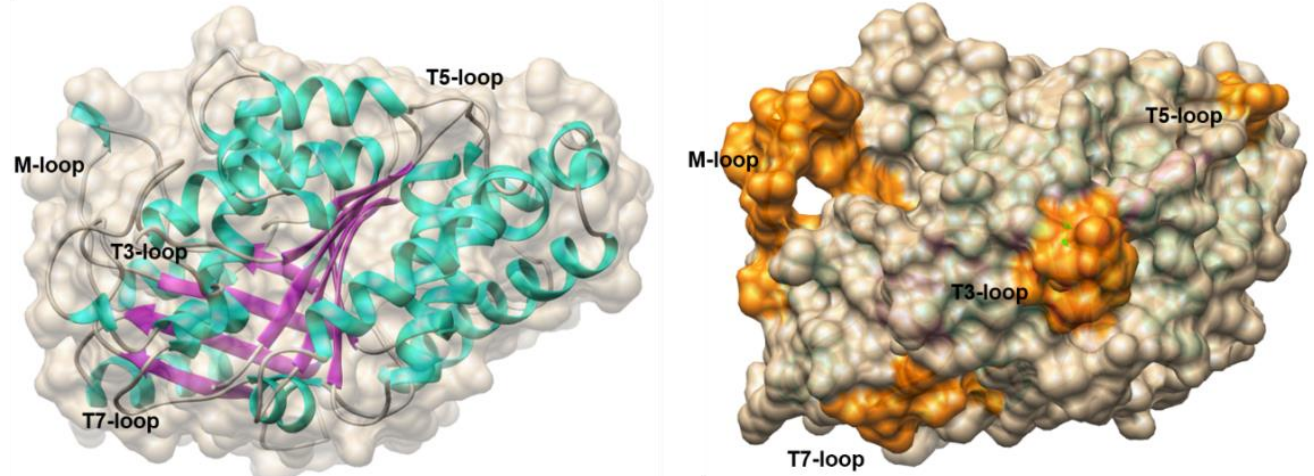

Figura 23. Proteína TUBB4A em superfície com regiões de loop destacadas

O algoritmo 3DLigandSite indicou clusters de sítios de ligação de GTP, magnésio e zinco para cada modelo baseado no alinhamento com estruturas e domínios conhecidos. A função de cada sítio foi anotada baseada em informações provenientes dos bancos de dados UniProtKB (P04350) e CDD (cd02187) e em estudos cristalográficos da proteína beta-tubulina. ${ }^{(176,179)} \mathrm{O}$ modelo da variante D295N, identificada nesse estudo, perdeu um sítio de ligação no resíduo N99 (interface do domínio de interação alfa/beta), assim como observado no modelo A271T(da variante patogênica), e, demonstrou alterações no sítio de ligação de GTP/GDP (E-site) com a aquisição de uma interação no resíduo T72, assim como nos modelos com as variantes sabidamente patogênicas. Os resíduos componentes dos sítios e domínios funcionais da proteína $T U B B 4 A$, assim como aqueles que foram perdidos ou adquiridos nos modelos variantes estão descritos no quadro 4.

Quadro 4. Sítios de ligação preditos para os modelos proteicos TUBB4A

\begin{tabular}{|c|c|c|c|c|c|c|}
\hline \multirow{5}{*}{$\begin{array}{l}\text { FUNÇÃO } \\
\text { Sítio ligante de } \\
\text { (GTP/GDP) } \\
\text { E-site (domínio N- } \\
\text { terminal) }\end{array}$} & RESÍDUOS* & $\mathrm{AA}^{\star \star}$ & \multirow[t]{3}{*}{ D295N } & \multirow[t]{3}{*}{ D295H } & \multirow[t]{3}{*}{ R2G } & \multirow[t]{3}{*}{ A271T } \\
\hline & $10-12$ & GQC & & & & \\
\hline & 15 & Q & & & & \\
\hline & 72 & $T$ & ADQUIRIU & & ADQUIRIU & ADQUIRIU \\
\hline & 138 & $S$ & & & & \\
\hline & $140-144$ & GGGTG & & & & \\
\hline & 181 & $E$ & & & & \\
\hline & 204 & $\mathrm{~N}$ & & & & \\
\hline & 222 & $\mathbf{Y}$ & PERDEU & & & \\
\hline & 226 & $\mathrm{~N}$ & & & & \\
\hline
\end{tabular}


...continuação

\begin{tabular}{|c|c|c|c|c|c|c|}
\hline Interface do domínio & 16 & I & & & & \\
\hline alfa/beta & 67 & $\mathrm{D}$ & & & & \\
\hline & $69-71$ & EPG & & & & \\
\hline & $97-98$ & $A G$ & & & & \\
\hline & 99 & $\mathbf{N}$ & PERDEU & & & PERDEU \\
\hline & 100/103/169 & $\mathrm{N} / \mathrm{K} / \mathrm{V} / \mathrm{D} /$ & & & & \\
\hline & $/ 177 / 179$ & V & & & & \\
\hline & 181 & $E$ & & & & \\
\hline Sítio ligante de & 16 & 1 & & & & \\
\hline magnésio - $\mathrm{Mg}^{2+}$ & 67/69/97/16 & $\mathrm{D} / \mathrm{E} / \mathrm{A} / \mathrm{V} /$ & & & & \\
\hline & $9 / 177$ & $\mathrm{D}$ & & & & \\
\hline Interface do domínio & $2 / 131$ & $\mathrm{R} / \mathrm{Q}$ & & & & \\
\hline beta/alfa & $\begin{array}{l}245 / 247 / 251 \\
/ 256\end{array}$ & $\mathrm{G} / \mathrm{N} / \mathrm{R} / \mathrm{N}$ & & & & \\
\hline & $258-260$ & VPF & & & & \\
\hline & $322-324$ & SMK & & & & \\
\hline & 327 & $\mathrm{D}$ & & & & \\
\hline & $347-351$ & NNVKT & & & & \\
\hline Sítio ligante de & 246 & $\mathbf{L}$ & & PERDEU & & \\
\hline (GTP/GDP) & 252 & $\mathrm{~K}$ & & & & \\
\hline N-site (a-tubulina) & & & & & & \\
\hline Sítio ligante de zinco - & 280 & $\mathbf{Q}$ & ADQUIRIU & ADQUIRIU & ADQUIRIU & ADQUIRIU \\
\hline $\mathrm{Zn}^{2+}(\mathrm{M}-\mathrm{loop})$ & $281-282$ & YR & & & & \\
\hline
\end{tabular}

${ }^{\star}$ Resíduos numerados conforme TUBB4A (NP_006078). ${ }^{* *}$ Aminoácidos.

\subsubsection{GCH1}

c.439C>T:(p.Pro147Ser). No éxon 2, a substituição do nucleotídeo citosina (C) por um nucleotídeo timina / uracila (T/U) na posição 439 do RNAm, em heterozigose, resulta na troca da trinca CCA por uma UCA, alterando o aminoácido prolina (Pro) por um serina (Ser) na posição 147 da cadeia polipeptídica. Os aminoácidos prolina e serina, envolvidos nessa variante, possuem tamanho aproximado (97,12 Da e 87,08 Da) mas hidrofobicidade diferente (prolina é apolar enquanto serina é polar). Essa variante não foi encontrada em nenhum banco de dados populacional, mas estava descrita no banco de dados dbSNP (rs867158370). Foi predita como prejudicial à função proteica por todos os algoritmos in silico (Polyphen2: escore 0.997, SIFT: escore 0.000, MutationTaster: escore 0.99, PROVEAN: escore 7,51) e de impacto moderado segundo CADD (escore 26.9) (Figura 24).

GCH1:c.607G>A:(p.Gly203Arg). Da mesma forma, no éxon 5, a troca de uma guanina $(G)$ por uma adenina $(A)$ na posição 607 do RNAm, em heterozigose, resulta na troca da trinca GGG por uma AGG, alterando o aminoácido glicina (Gly) pelo aminoácido arginina (Arg) na posição 203 da proteína GTP ciclohidrolase I, durante o processo de tradução (Figura 24). Nessa variante, os aminoácidos glicina e arginina possuem características físico-químicas completamente 
diferentes, tanto em tamanho (57,05 Da e 156,19 Da), quanto em hidrofobicidade (apolar e polar) e carga (neutra e positiva), respectivamente. Essa variante está classificada como "patogênica" no banco de dados ClinVar (rs988395114) e foi predita como prejudicial à função proteica por todos os algoritmos in silico (Polyphen2: escore 1.000, SIFT: escore 0.000, Mutation Taster: escore:0.99 e PROVEAN: escore -3.64) com impacto moderado (CADD escore 29.2).

GCH1 é um gene conservado dentro do reino animal, conforme análise pelo Homologene, e possui ortólogos em todas as espécies selecionadas. A prolina na posição 147 foi conservada ao longo da evolução, se mantendo em todas as espécies, enquanto a glicina na posição 203 da proteína foi conservada em vertebrados.

\section{GCH1}

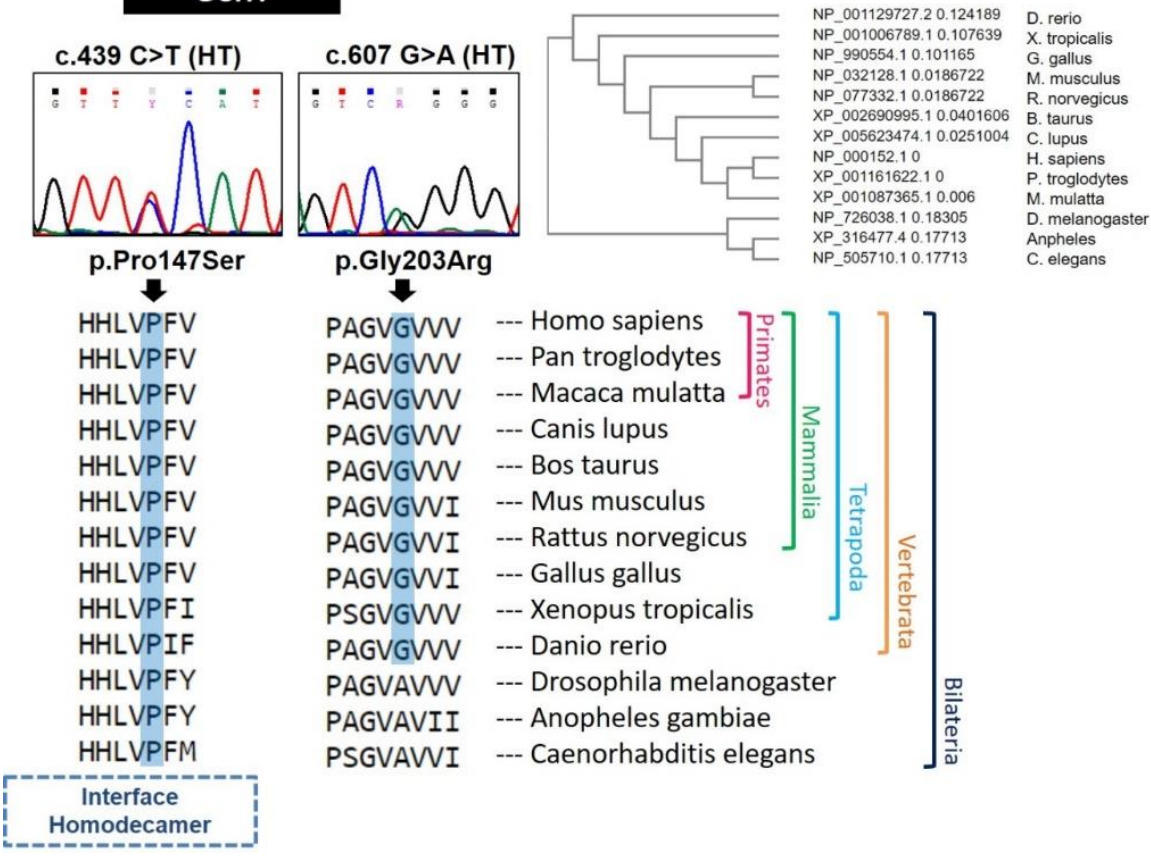

Acima, os eletroferogramas das variantes c.439C >T (à esquerda) e c.607G >A (à direita), ilustram a troca dos nucleotídeos citosina (pico azul) por timina (pico vermelho) e de guanina (pico preto) por adenina (verde), ambos em heterozigose. Abaixo, os trechos das sequências de aminoácidos da proteína GTP ciclohidrolase I foram alinhados com as mesmas sequências de diversas espécies, demonstrando que o aminoácido prolina (Pro) na posição 147, constituinte de uma região de interface homodecamer, foi conservado em todas as espécies selecionadas, enquanto o aminoácido glicina (Gly) na posição 203 foi conservado somente nos vertebrados.

Figura 24. Variantes no gene $\mathrm{GCH} 1$

Na modelagem molecular da proteína GTP ciclohidrolase I, 78\% dos resíduos foram modelados com mais de $90 \%$ de confiança, com a maior parte da proteína modelada por homologia (194 resíduos alinhados). A estrutura molde selecionada foi a c1is7F (PDB 1IS7), correspondente à estrutura da proteína GTP 
ciclohidrolase I em complexo com sua proteína reguladora GFRP da espécie rattus novergicus (rato), obtida por meio da difração de raios $x$ com resolução de $2.8 \AA ̊$.

Geramos modelos da proteína selvagem e das variantes (p.P147S e p.G203R). Todos os modelos estavam adequados conforme análise de qualidade. Segundo análise de Ramachandran, os resíduos 117 e 218 estavam em regiões desfavoráveis do modelo e os resíduos 79, 122, 137, 138, 163, 177, 211 e 219 foram preditos como rotâmeros, com cadeias laterais que podem não ter sido modeladas idealmente. Além disso, a região correspondente aos resíduos 1 à 67 (região que não foi modelada por homologia) demonstrou estar desordenada.

Todos os resíduos preditos como sítios catalíticos ou de interação com outras proteínas, assim como a região de bolsão também predita nos modelos, foram correspondentes aos resíduos registrados no banco de dados UniProt.

Como uma enzima, GTP ciclohidrolase I possui diversos sítios de interação proteica distribuídos ao longo da superfície, que são expostos conforme padrão de ativação dos sítios de ATP e fosforilação. O aminoácido prolina na posição 147 é um desses sítios de interação com outras proteínas (na interface homodecamer), e é um resíduo próximo aos sítios de ligação de GTP e zinco nos resíduos 143 e 144. Em relação ao modelo selvagem, o modelo com a variante p.P147S perdeu 4 das 7 pontes de hidrogênio que estabilizavam as fitas $\beta 3$ e $\beta 4$ no centro da proteína. Da mesma forma, o resíduo 203, envolvido na variante p.G203R, constitui um resíduo na fita $\beta 6$ e parece afetar a mesma região que a variante p.P147S, desestabilizando as fitas $\beta 3$ e $\beta 4$ e o loop com os sítios ativos 143 e 144, quando alterado pela variante (Figura 25). 
A) Modelo selvagem

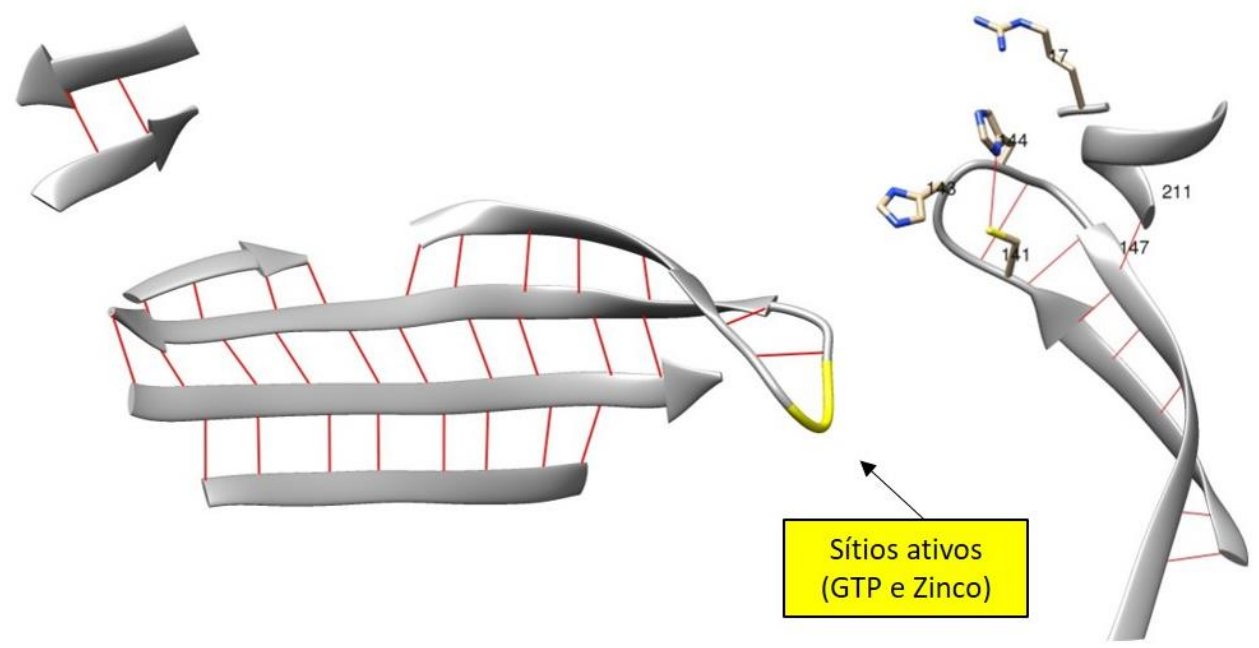

B) Modelo variante p.P147S

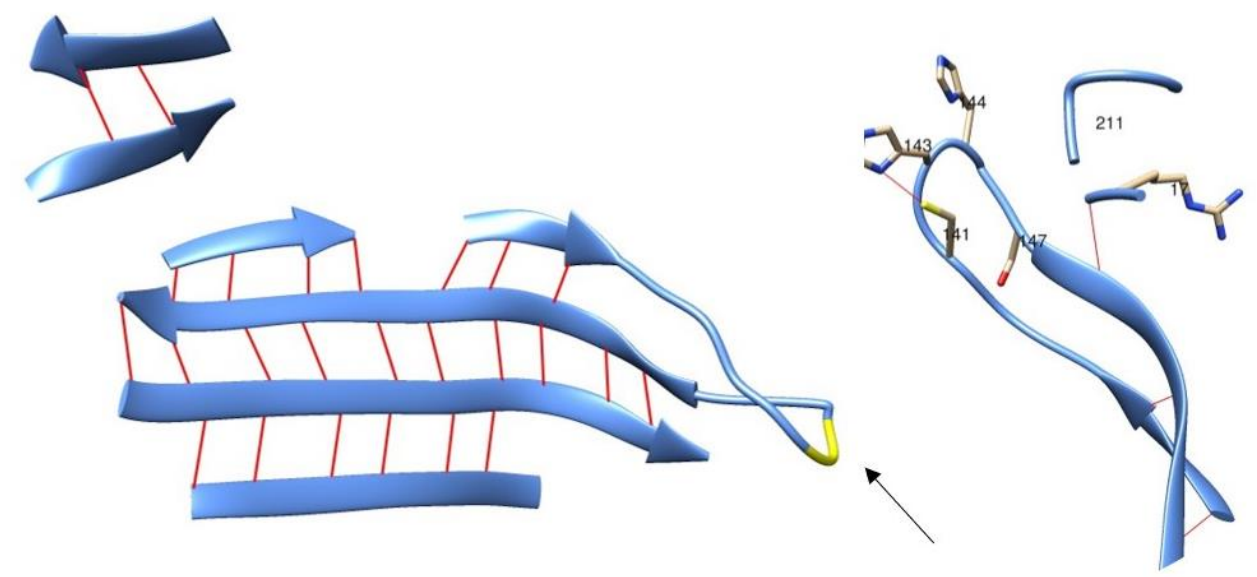

C) Modelo variante p.G203R

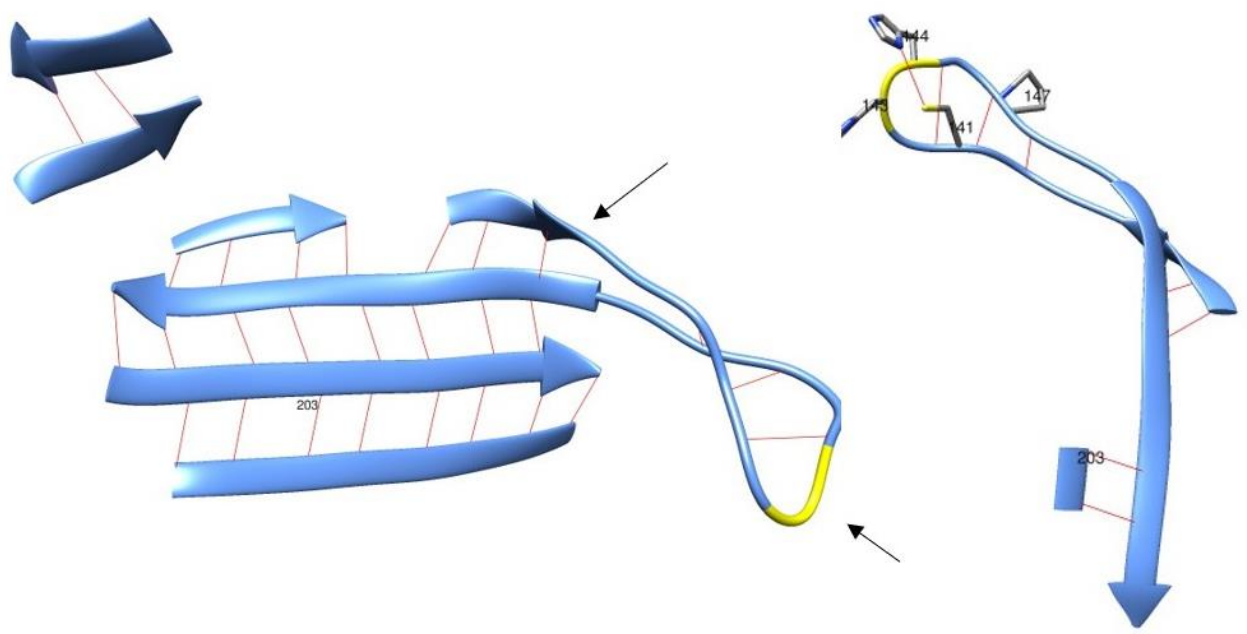

À direita está representada a estruturas das fitas $\beta$ nos modelos selvagem (acima) e variante (abaixo). As linhas vermelhas indicam ligações por pontes de hidrogênio, estabelecidas entre os resíduos.

Figura 25. Alterações conformacionais e nas ligações por pontes de hidrogênio no modelo $\mathrm{GCH} 1 \mathrm{com}$ a variante p.P147S 


\subsubsection{TH}

c.81G>T:(p.Glu27Asp). A substituição do nucleotídeo guanina $(G)$ por timina / uracila (T/U) na posição 81 do RNAm, em heterozigose, resulta na troca da trinca GAG por uma GAU, alterando o aminoácido glutamato (Glu) por um aspartato (Asp) na posição 27 da proteína tirosina hidroxilase, durante o processo de tradução. $O$ gene TH é conservado em animais Bilateria, com ortólogos em todas as espécies selecionadas, porém, o aminoácido Glutamato na posição 27 da proteína não está em região conservada ao longo da evolução (Figura 26).

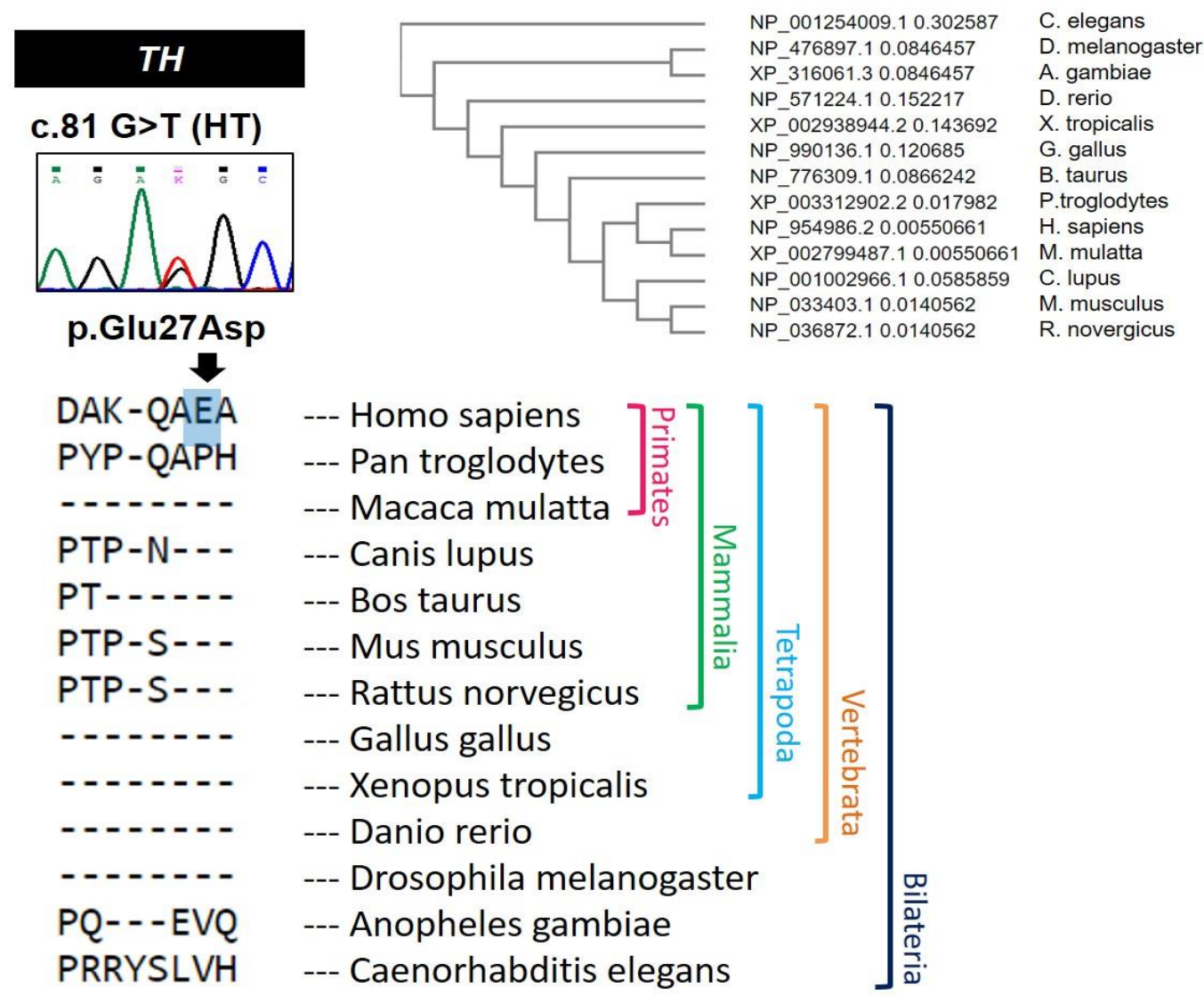

Acima está ilustrado o eletroferograma da variante c.81G>T, com a troca de um nucleotídeo guanina (pico preto) por timina (pico vermelho), em heterozigose. Abaixo, o trecho da sequência de aminoácidos da proteína tirosina hidroxilase foi alinhado com a mesma sequência de diversas espécies, demonstrando que o aminoácido glutamato (Glu) na posição 27 não foi conservado entre as espécies.

Figura 26. Variante no gene $T H$

Os aminoácidos glutamato e aspartato, envolvidos nessa variante, possuem características semelhantes em relação ao tamanho (128,12 Da e 115,09 Da) e são polares de carga negativa. A variante p.Glu27Asp (rs139742336) estava descrita nos bancos de dados gnomAD (0,17\%) e AbraOM (0,08\%). Os algoritmos in silico 
predizeram essa variante como provavelmente prejudicial (Polyphen2 escore 0.524), tolerada (SIFT escore 0.1), polimorfismo (Mutation Taster escore 0.67) e neutra (PROVEAN escore -0.74) de impacto moderado (CADD escore 22.6).

Como a variante estava em heterozigose e não identificamos quaisquer outras variantes que pudessem atestar heterozigose composta, por estar em uma região não conservada da proteína e ser predita como neutra pela maioria dos algoritmos in silico, não identificamos evidências suficientes de patogenicidade para essa variante.

\subsubsection{DDC}

c.715A>T:(p.Met239Leu). A troca do nucleotídeo adenina (A) por timina / uracila (T/U) na posição 715 do RNAm leva à troca da trinca AUG por UUG, alterando o aminoácido metionina (Met) por leucina (Leu) na posição 239 da proteína dopa descarboxilase, durante o processo de tradução. Os dois aminoácidos envolvidos nessa variante possuem características físico-químicas semelhantes, ambos são apolares de carga neutra e possuem tamanho aproximado (131,19 Da e 113,16 Da). Conforme figura 27, a metionina na posição 239 não foi um aminoácido conservado ao longo da evolução. A variante p.Met239Leu (rs11575376) está descrita nos bancos de dados gnomAD (0,04\%) e ABraOM $(0,08 \%)$ e foi predita como benigna (Polyphen2, escore 0.00), tolerada (SIFT, escore 0.057), polimorfismo (Mutation Taster, escore 0.99), neutra (PROVEAN, escore 0.11) e de baixo impacto na função proteica (CADD, escore 10.89). Essa variante compõe uma região de fitas $\beta$-pregueadas (assim como no caso $\mathrm{GCH} 1$ ) mas não altera quaisquer pontes de hidrogênio entre elas e nem entre os resíduos adjacentes. 


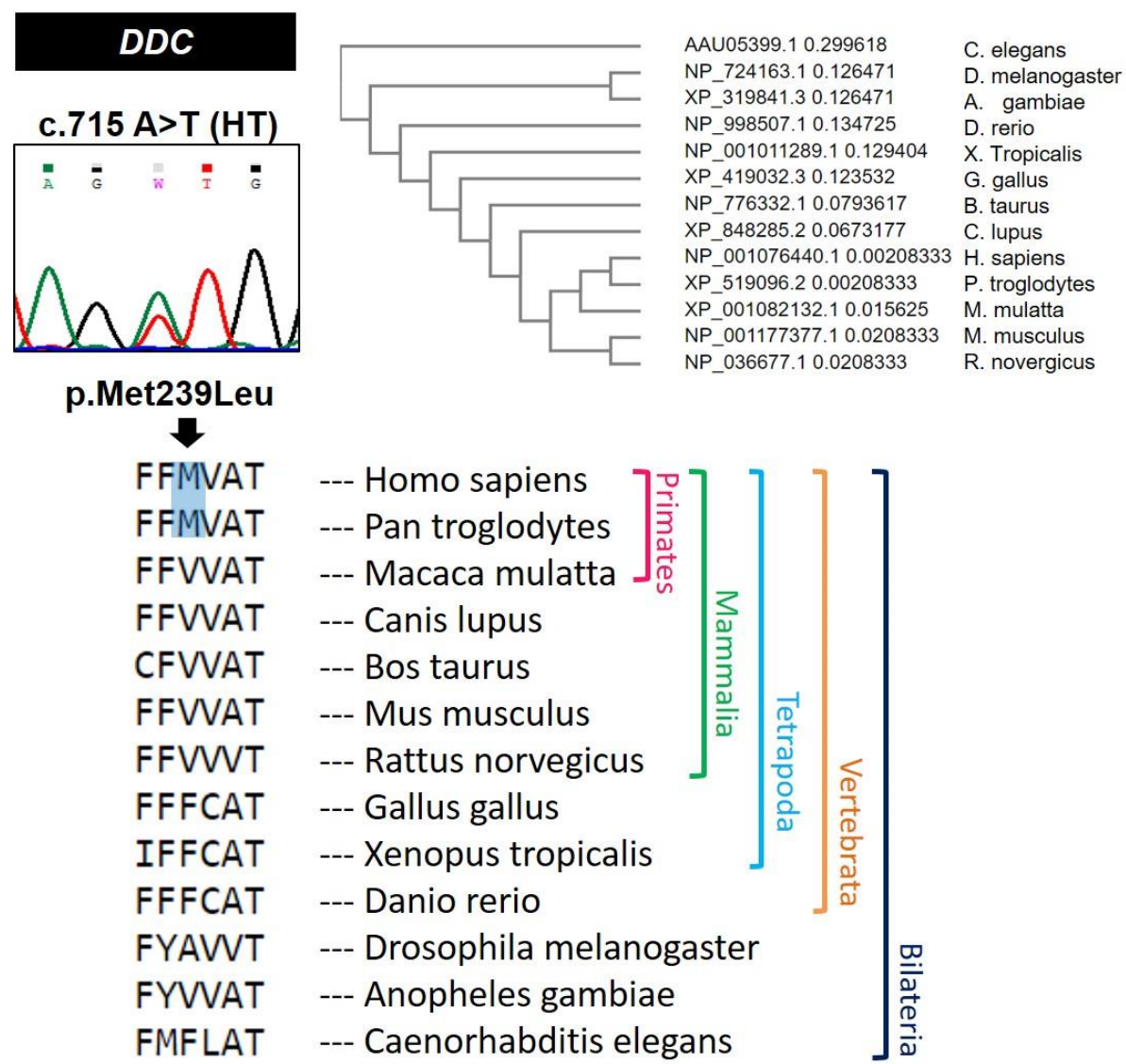

Acima está ilustrado o eletroferograma da variante c.715A $>\mathrm{T}$, com a troca de um nucleotídeo adenina (pico verde) por timina (pico vermelho), em heterozigose. Abaixo, o trecho da sequência de aminoácidos da proteína dopa descarboxilase foi alinhado com a mesma sequência de diversas espécies, demonstrando que o aminoácido metionina (Met) na posição 230 não foi conservado entre as espécies.

Figura 27. Variante no gene $D D C$

c.568_569insCGATC:(p.GIn190Profs*3). Essa variante corresponde à inserção de cinco nucleotídeos no éxon 5 do gene $D D C$, causando alteração na matriz de leitura da proteína dopa descarboxilase com formação de um códon de parada após 3 aminoácidos (Figura 28). A proteína resultante perdeu grande parte do domínio descarboxilase, a maioria dos sítios ligantes de fosfato e um sítio catalítico. A análise do efeito molecular não foi possível devido à perda de mais de $50 \%$ da cadeia polipeptídica nessa variante. Após investigação familiar, confirmamos a mesma variante na mãe assintomática do probando (em heterozigose) e estava ausente no pai e na irmã (Figura 29). 

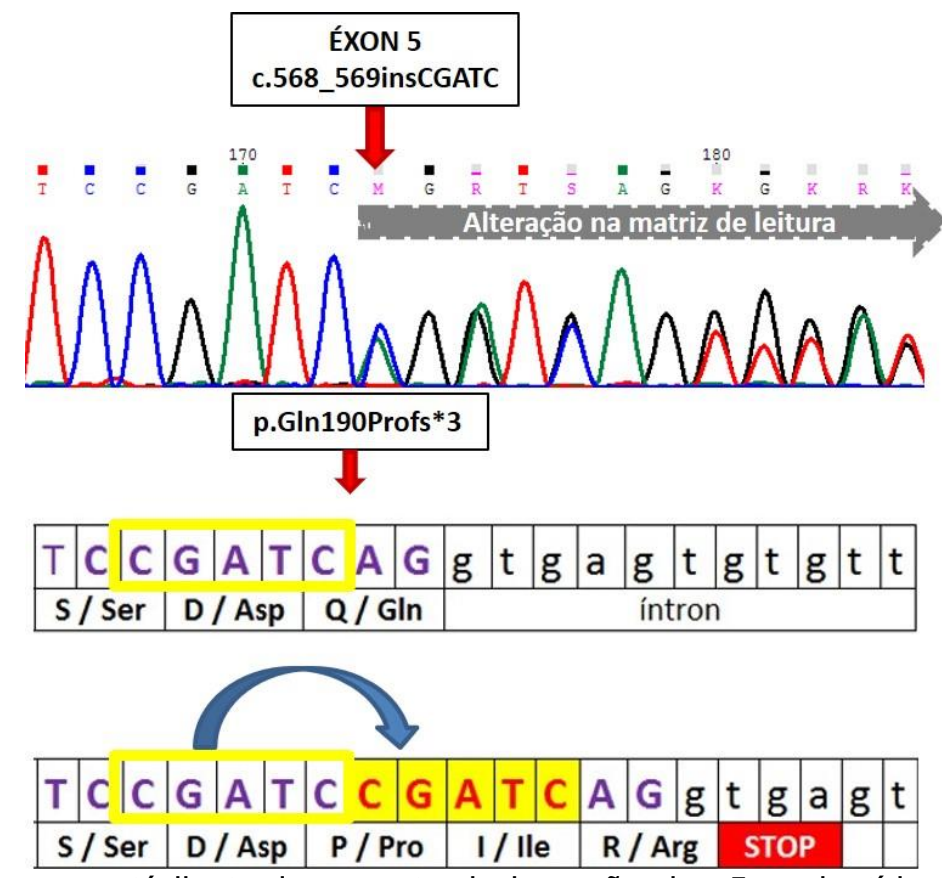

No eletroferograma está ilustrado o ponto de inserção dos 5 nucleotídeos, resultando na alteração da matriz de leitura. A inserção dos nucleotídeos (CGATC) causou a troca do aminoácido glutamina (GIn) por um prolina (Pro) na posição seguinte, a inserção de mais dois aminoácidos (Isoleucina - lle e Arginina - Arg) e por fim um códon de parada (TGA), levando à formação de uma proteína truncada.

Figura 28. Variante com inserção no gene $D D C$
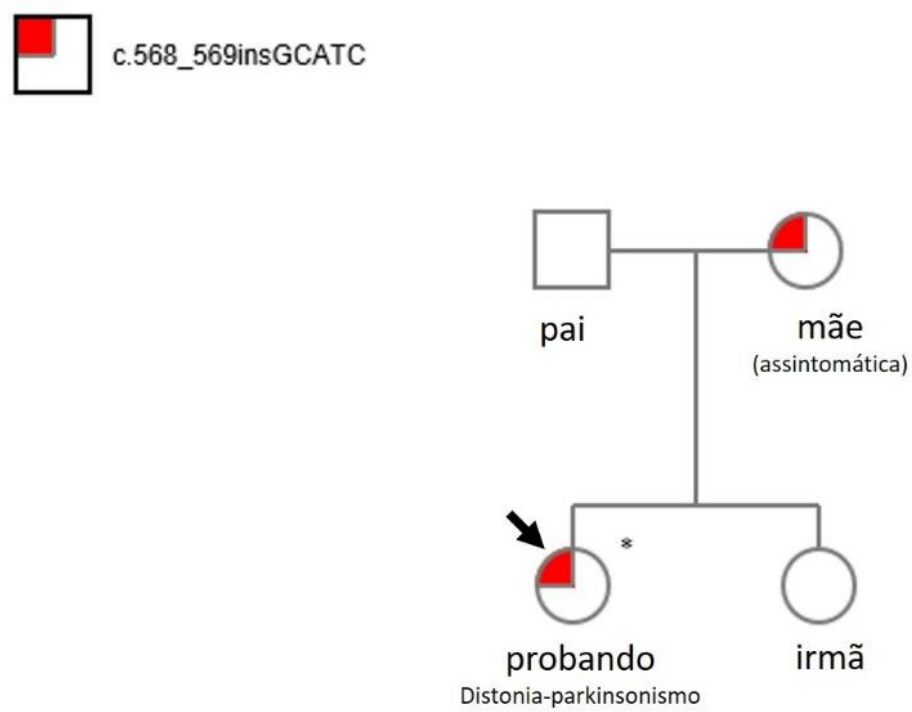

A variante foi identificada na mãe do probando e estava ausente no pai e na irmã. Nenhum dos familiares é afetado.

Fonte: Progeny Genetics [Program]. Delray Beach: Progeny Genetics LLC; c1996-2019 [cited 2019 Nov 25]. Available from: http://pedigree.progenygenetics.com/

Figura 29. Heredograma do probando com inserção no gene $D D C$ 


\subsubsection{THAP1}

c.289 C>T:(p.Gln97*). Entre as substituições pontuais de um único nucleotídeo, identificamos a variante c.289C >T (p.Gln97*) no gene THAP1. Nessa variante, denominada substituição sem sentido, a troca do nucleotídeo citosina (C) por timina ( $T$ ) resulta na alteração da trinca CAG por um dos códons indicadores de término de transcrição (TAG) no RNAm, levando à tradução de uma proteína truncada. (Figura 30). No banco de dados ClinVar, essa variante está descrita como patogênica, mas não foi encontrada em nenhum dos bancos de dados populacionais. Somente dois dos algoritmos resultaram em predição para essa variante como causadora de doença (MutationTaster, escore 0.99) e de impacto forte (CADD, escore 35). Análise molecular não foi possível para essa proteína, uma vez que o modelo gerado não possuía estrutura molde elucidada experimentalmente, com níveis de homologia e confiança aceitáveis (somente $40 \%$ dos resíduos foram modelados com mais de $90 \%$ de confiança).
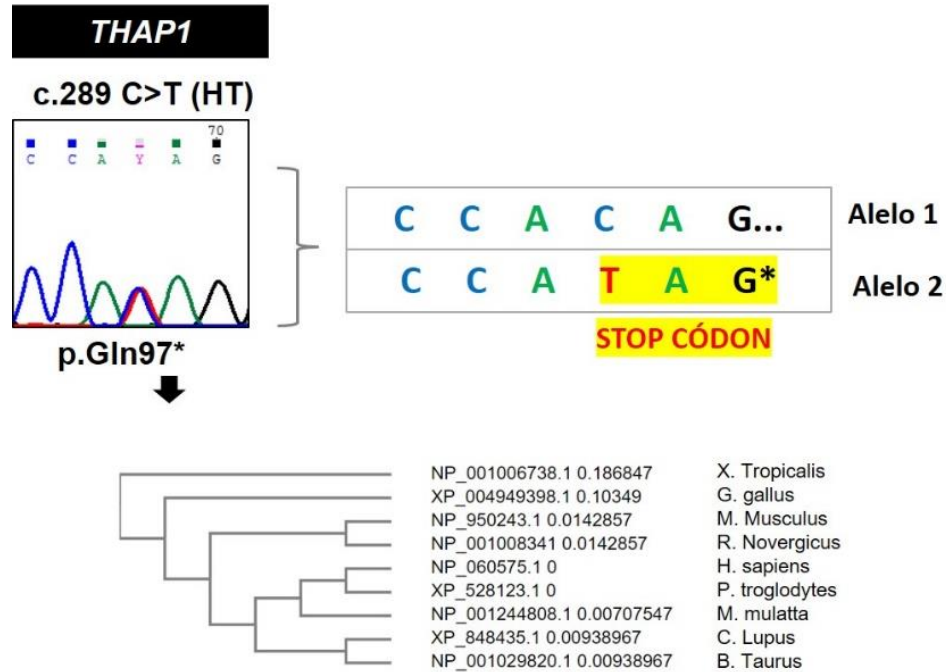

$$
\begin{array}{ll}
\text { NP_001006738.1 0.186847 } & \text { X. Tropicalis } \\
\text { XP_004949398.1 0.10349 } & \text { G. gallus } \\
\text { NP_950243.1 } 0.0142857 & \text { M. Musculus } \\
\text { NP_001008341 0.0142857 } & \text { R. Novergicus } \\
\text { NP_060575.1 } & \text { H. sapiens } \\
\text { XP_528123.10 } & \text { P. troglodytes } \\
\text { NP_001244808.10.00707547 } & \text { M. mulatta } \\
\text { XP_848435.10.00938967 } & \text { C. Lupus } \\
\text { NP_001029820.10.00938967 } & \text { B. Taurus }
\end{array}
$$

À esquerda, o eletroferograma da variante c.289C>T ilustra a substituição do nucleotídeo citosina (pico azul) por um timina (pico vermelho), em heterozigose. À direita, a sequência de nucleotídeos selvagem (CAG) pareada com a sequência alterada que codifica um códon indicador de término de transcrição (TAG), truncando a proteína.

Figura 30. Variante no gene THAP1 


\subsubsection{SGCE}

c.584G>A:(p.Arg195His). A substituição do nucleotídeo guanina $(G)$ por adenina $(A)$ na posição 584 do RNAm, em heterozigose, resulta na troca da trinca CGC por uma CAC, alterando o aminoácido arginina (Arg) por histidina (His) na posição 195 da proteína épsilon sarcoglicana, durante processo de tradução. O gene SGCE foi conservado em vertebrados e possui ortólogos nas espécies selecionadas, onde a arginina na posição 195 se manteve conservada (Figura 31). Os aminoácidos envolvidos são semelhantes em suas características, ambos são polares de carga positiva e diferem pouco no tamanho (arginina com 156,19 Da e a histidina com 137,14 Da). Essa variante ( $r$ 746331571) estava descrita no banco de dados gnomAD com frequência de $0,03 \%$ e foi predita como provavelmente prejudicial (Polyphen2, escore 0.921), prejudicial (SIFT, escore 0.04), causadora de doença (Mutation Taster, escore 0.99), de efeito neutro (PROVEAN, escore -0.71) e de impacto moderado (CADD escore 25). Esse mesmo probando possui uma variante no gene GNAL.

Não foi possível a realização da modelagem molecular para essa proteína devido à ausência de estruturas moldes com homologia suficiente (somente23\% dos resíduos foram modelados).

\section{SGCE}

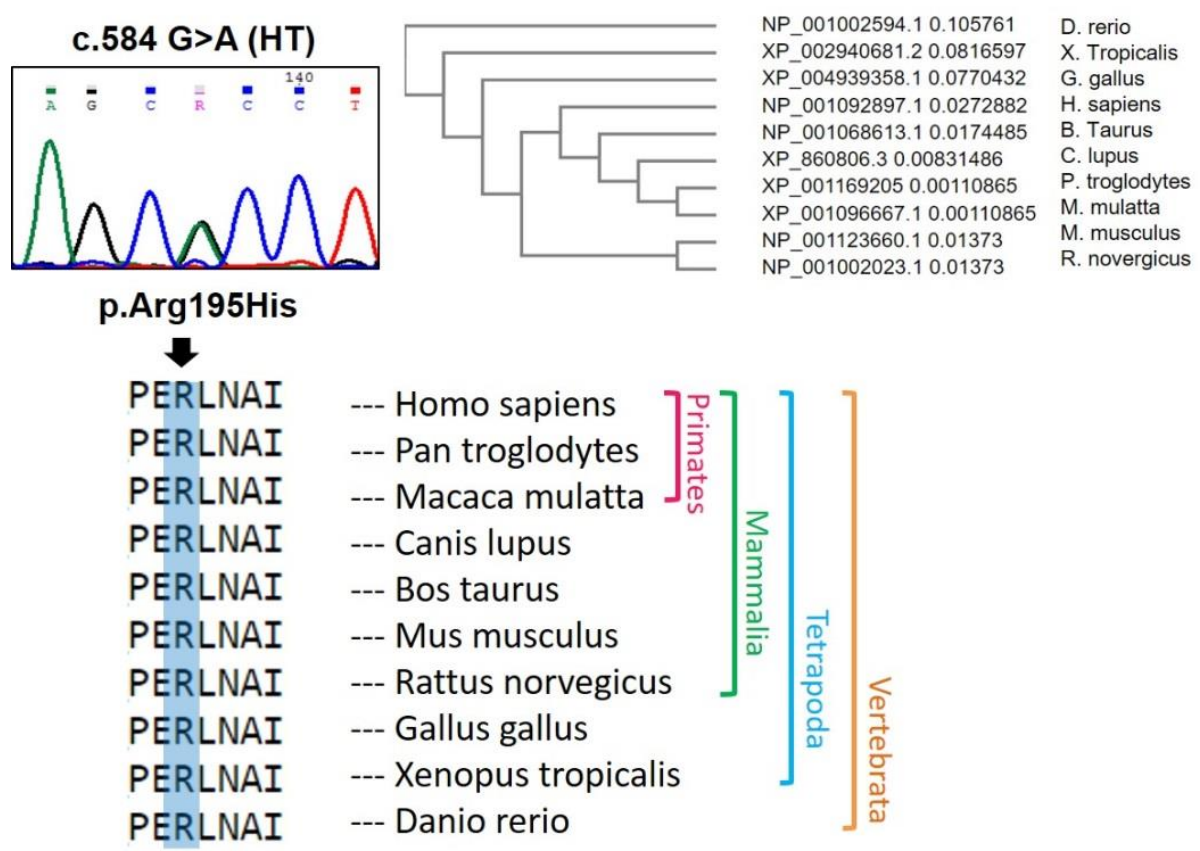

Eletroferograma da variante c.584G >A, com a troca de um nucleotídeo guanina (pico preto) por adenina (pico verde), em heterozigose. Abaixo, o trecho da sequência de aminoácidos da proteína épsilon sargoglicana foi alinhado com a mesma sequência de diversas espécies, demonstrando que o aminoácido arginina (Arg) na posição 195 foi conservado em todas as espécies selecionadas.

Figura 31. Variante no gene SGCE 


\subsubsection{ATP1A3}

c.1472A>G:(p.Asn491Ser)

e

c.2653G>A:(p. Val885lle).

Respectivamente, as substituição dos nucleotídeos adenina (A) por guanina $(G)$ na posição 1472 (éxon12) e guanina por adenina na posição 2653 (éxon19) do RNAm, ambas em heterozigose, resultam na troca das trincas AAC por AGC e GTC por AUC, alterando os aminoácidos asparagina (Asn) por serina (Ser) e valina (Val) por isoleucina (lle), nas posições 491 e 885 da cadeia polipeptídica de ATP1A3 durante o processo de tradução (Figura 32). Os aminoácidos envolvidos são semelhantes, com tamanho aproximado (asparagina 114,11 Da e serina 87,08 Da; valina 99,14 Da e isoleucina 113,16 Da), mesma hidrofobicidade (asparagina e serina apolares e valina e isoleucina polares) e carga neutra.

\section{ATP1A3}

c. $1472 A>G(H T)$

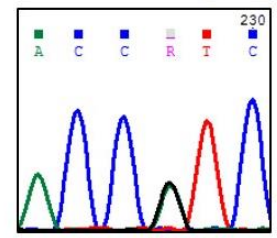

p.Asn491Ser

PNDNRY

PNDNRY

PNDNRY

PNDNRY

PNDNRY

PNDNRY

PNDNRY

PNDNRY

PNDNRY

NNDNRY

TNDPRY

PSDPRY

- -GDHY
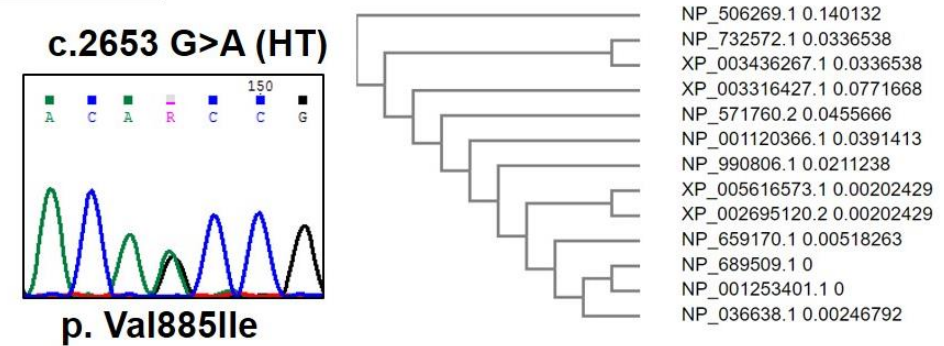

C. elegans

D. melanogaster

A. gambiae

P.troglodytes

D. rerio

$\mathrm{X}$. tropicalis

G. gallus

C. lupus

B. taurus

M. musculus

H. sapiens

R. novergicus

\begin{tabular}{|c|c|c|c|c|}
\hline RTVNDLE| & --- Homo sapiens & & & \\
\hline RTVNDLE| & --- Pan troglodytes & & & \\
\hline RTVNDLE| & --- Macaca mulatta $]$ & & & \\
\hline RTVNDLE| & --- Canis lupus & $\frac{3}{2}$ & & \\
\hline RTVNDLE| & --- Bos taurus & & & \\
\hline RTVNDLE| & --- Mus musculus & $\frac{\bar{\omega}}{\bar{v}}$ & 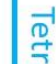 & \\
\hline RTVNDLE| & --- Rattus norvegicus & & $\frac{2}{2}$ & \\
\hline RTINDLE & --- Gallus gallus & & $\frac{2}{2}$ & \\
\hline RSVNDLE| & --- Xenopus tropicalis & & & \\
\hline RAMNDLE & --- Danio rerio & & & \\
\hline KAVNDLT| & --- Drosophila melanog & faste & & \\
\hline KAINDLT| & --- Anopheles gambiae & & & \\
\hline RAYNNVLI & --- Caenorhabditis eleg & & & \\
\hline
\end{tabular}

Os eletroferogramas acima ilustram as substituições dos nucleotídeos adenina (pico verde) por guanina (pico preto) à esquerda, e guanina por adenina à direita. Conforme alinhamento protéico entre diversas espécies, os aminoácidos asparagina e valina nas posições 491 e 885 , foram parcialmente conservados entre vertebrados e mamíferos, respectivamente.

Figura 32. Variantes no gene ATP1A3 
A variante p.Asn491Ser (rs782775696) já estava descrita no bancos de dados gnomAD, com frequência de $0,02 \%$ e foi predita como benigna (Polyphen2, escore 0.04), tolerada (SIFT, escore 0.605), causadora de doença (MutationTaster, escore 0.99), neutra (PROVEAN, escore 0.60) e de impacto baixo (CADD escore 6.68). A filha sem distonia foi testada e negativa para essa variante Da mesma forma, a variante p.Val885lle (rs149600313) com frequência de $0,03 \%$ no mesmo banco, e também predita como benigna (Polyphen2, escore 0.05), tolerada (SIFT, escore 0.712), causadora de doença (MutationTaster, escore 0.61), neutra (PROVEAN, escore 0.05) e de impacto baixo (CADD escore 7.45), além disso, estava descrita como benigna no banco de dados ClinVar.

Como essas variantes foram identificadas em casos com outras variantes de potencial patológico com maior significância, por envolverem aminoácidos semelhantes quimicamente e por não terem sido preditas como prejudicial à função proteica, não realizamos a análise por modelagem molecular.

\subsubsection{PRKRA}

\section{c.665C>T:(p.Pro222Leu) e $\quad c .795 C>A:(p . S e r 265 A r g)$.}

Respectivamente, a troca do nucleotídeo citosina (C) por um timina / uracila (T/U) na posição 665 (éxon7) ou por adenina (A) na posição 795 (éxon 8) do RNAm leva à troca das trincas CCU por CUU e AGC por AGA, alterando os aminoácidos prolina (Pro) por leucina (Leu) na posição 222 e serina (Ser) por arginina (Arg) na posição 265 da proteína PACT, durante o processo de tradução (Figura 33). Os aminoácidos prolina e leucina, alterados na posição 222, são apolares de carga neutra e com tamanho aproximado (97,12 Da e 113,16 Da), enquanto os aminoácidos serina e arginina, alterados na posição 265 , são polares, se diferenciam na carga (neutra e positiva) e no tamanho (87,08 Da e 156,19 Da).

O gene PRKRA é conservado em animais Bilateria, com ortólogos nas espécies selecionadas para alinhamento, com exceção da espécie Gallus gallus. A prolina no resíduo 222 se mostrou conservada em mamíferos e a serina na posição 265 em tetrápodes.

A variante p.Pro222Leu já estava descrita como patogênica no banco de dados ClinVar (rs121434410), com frequência de 0,009\% no banco de dados 
gnomAD. A variante p.Ser265Arg não estava descrita em nenhum banco de dados e não foi encontrada em 246 cromossomos de controles brasileiros saudáveis.

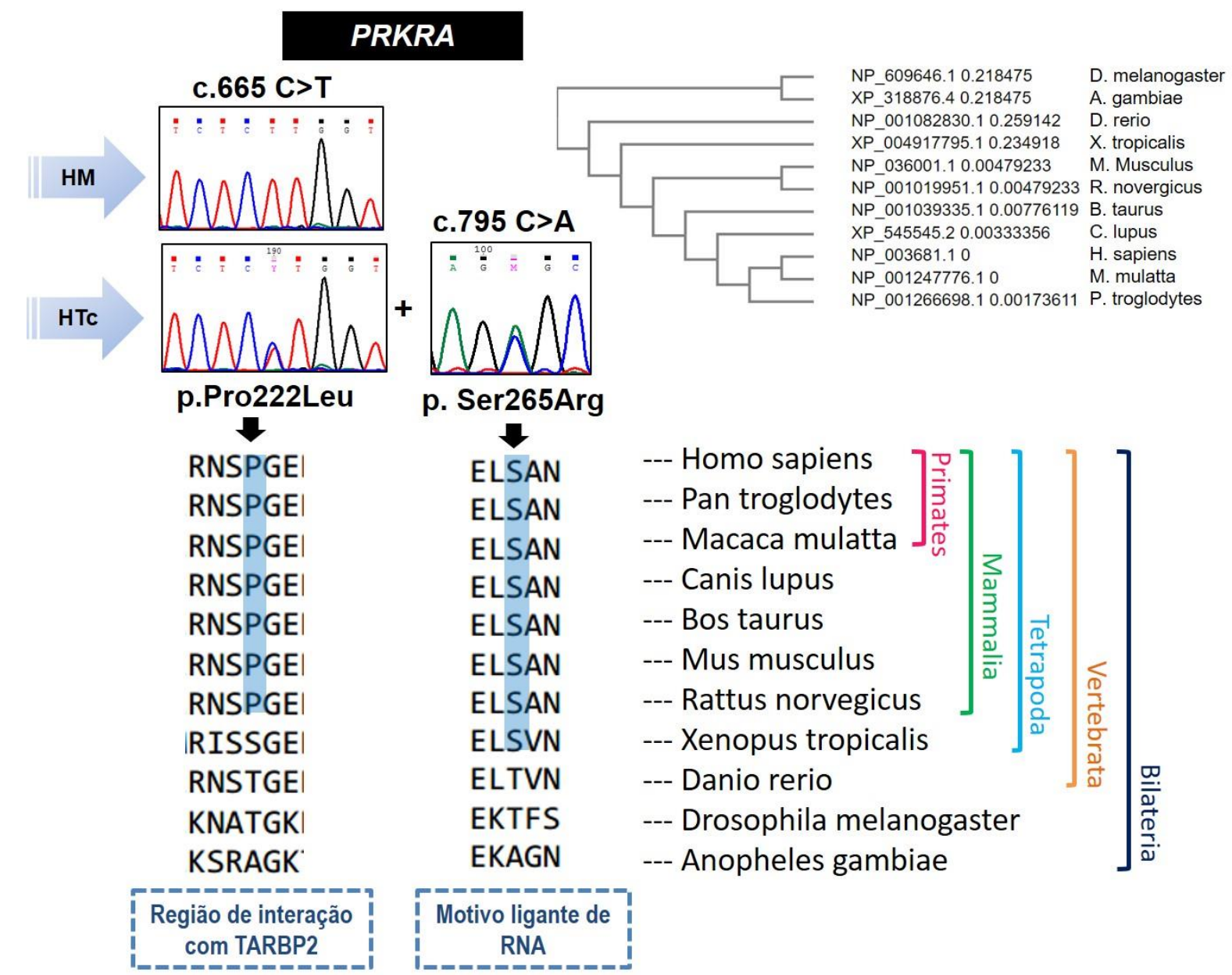

Os eletroferogramas à esquerda ilustram a troca de um nucleotídeo citosina (pico azul) por timina (pico vermelho) na posição 665 do RNAm, de forma homozigótica (acima) e heterozigótica (abaixo). Já à direita, está ilustrada a substituição de um nucleotídeo citosina (pico azul) por adenina (pico verde) em heterozigose. Essas variantes levam à troca dos aminoácidos prolina (Pro) por leucina (Leu) na posição 222, e, serina (Ser) por arginina (Arg) na posição 265, os quais foram conservados entre os mamíferos e constituem regiões funcionais de interação da proteína PACT com TARBP2 e RNA.

Figura 33. Variantes no gene PRKRA

A predição de patogenicidade dos algoritmos in silico resultaram em benigna (Polyphen2 escore 0.002), prejudicial (SIFT escore 0.048), causadora de doença (MutationTaster escore 0.98), neutra (PROVEAN escore -0.75) e de impacto moderado (CADD escore 21.5) para a variante p.Pro222Leu. Já para a variante p.Ser265Arg resultaram em prejudicial (Polyphen2 escore 1.00, SIFT escore $0.001 \mathrm{e}$ PROVEAN escore -3.491), polimorfismo (MutationTaster escore 0.99) e de impacto moderado (CADD escore 28.1). 
Por falta de homologia com estruturas já elucidadas experimentalmente, a modelagem molecular para essa proteína não foi realizada, uma vez que somente $46 \%$ dos aminoácidos foram alinhados.

\subsubsection{CIZ1}

Identificamos quatro variantes no gene $C I Z 1$, considerando a isoforma 6 que é o transcrito mais longo dessa proteína.

A isoforma 6 não é expressa no sistema nervoso, somente as isoformas 1 e 2, que são expressas no cérebro, principalmente na substância negra e cerebelo (onde a isoforma 2 possui maiores níveis em relação à isoforma 1).

Entretanto, devido ao evento de splicing alternativo, as isoformas $1 \mathrm{e}$ 2 diferem da isoforma 6 . Nenhuma delas expressa a região total do éxon 1, parcial do éxon 2 e total do éxon 13. A isoforma 2 difere da isoforma 1 por não expressar parte do éxon 8 (Figura 34). Portanto, prosseguimos as análises de patogenicidade somente para as variantes c.1264 C>A (p.Gln422Lys) e c.1997 A>G (p.Asp666Gly), que são codificadas nas isoformas 1 e 2 , expressas no cérebro.

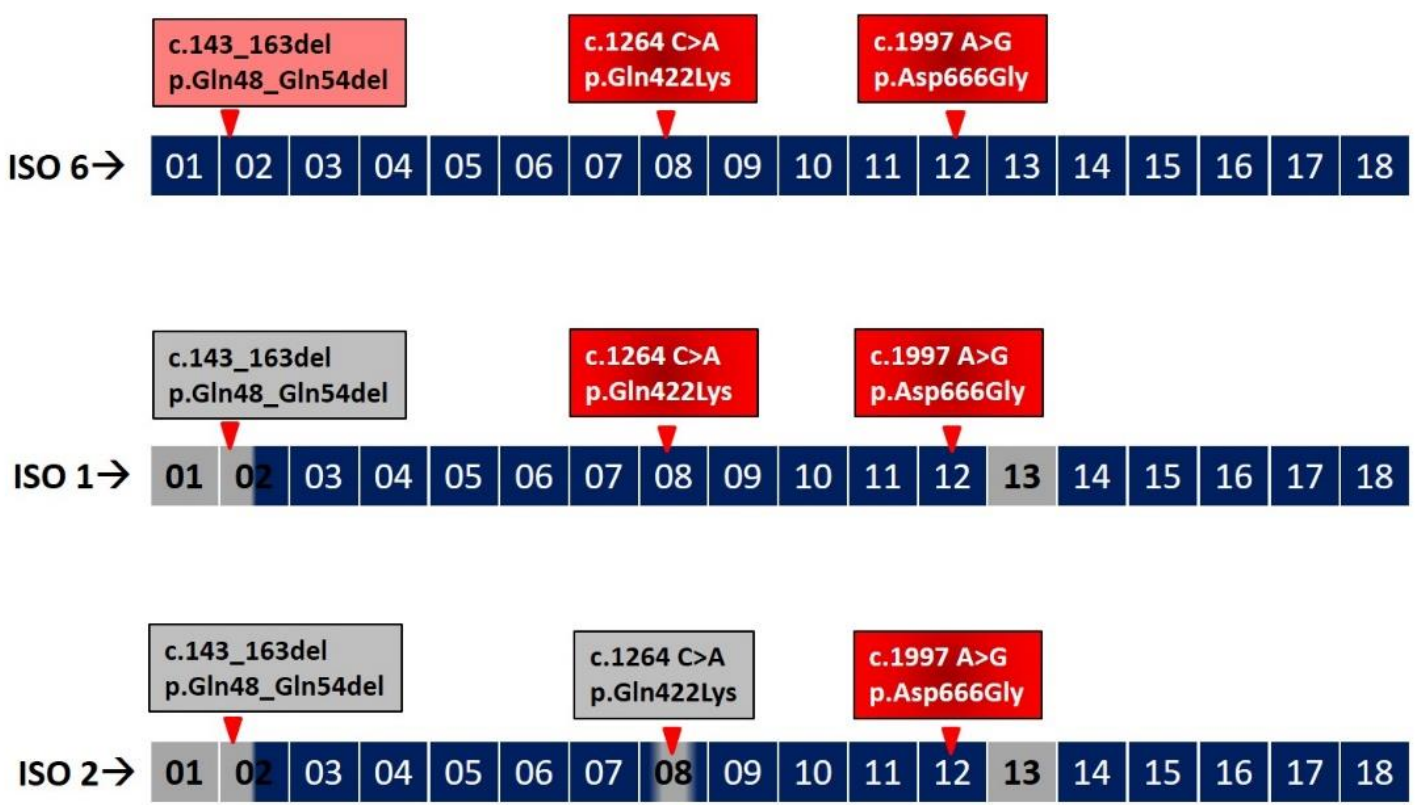

Isoforma (ISO). As setas vermelhas indicam as posições das variantes nas isoformas correspondentes. As regiões codificadas estão ilustradas em azul e as regiões não codificadas estão ilustradas em cinza. A nomenclatura das variantes foi baseada na isoforma 1 (NM_012127).

Figura 34. Diferenças no padrão de expressão do gene $C I Z 1$ 


\section{c.1354C>A:(p.GIn452Lys) e c.2087A>G:(p.Asp696Gly).}

Respectivamente, a troca de uma citosina (C) por uma adenina (A) na posição 1354 (éxon 8) e a troca de uma adenina (A) por guanina (G) na posição 2087 (éxon 12) do RNAm levam à troca das trincas CAG por $A A G$ e GAC por GGC, alterando os aminoácidos glutamina (Gln) por aspartato (Asp) na posições 452, e aspartato (Asp) por Glicina (Gly) na posição 696 da proteína ClZ1, durante o processo de tradução (Figura 35).

\section{CIZ1}

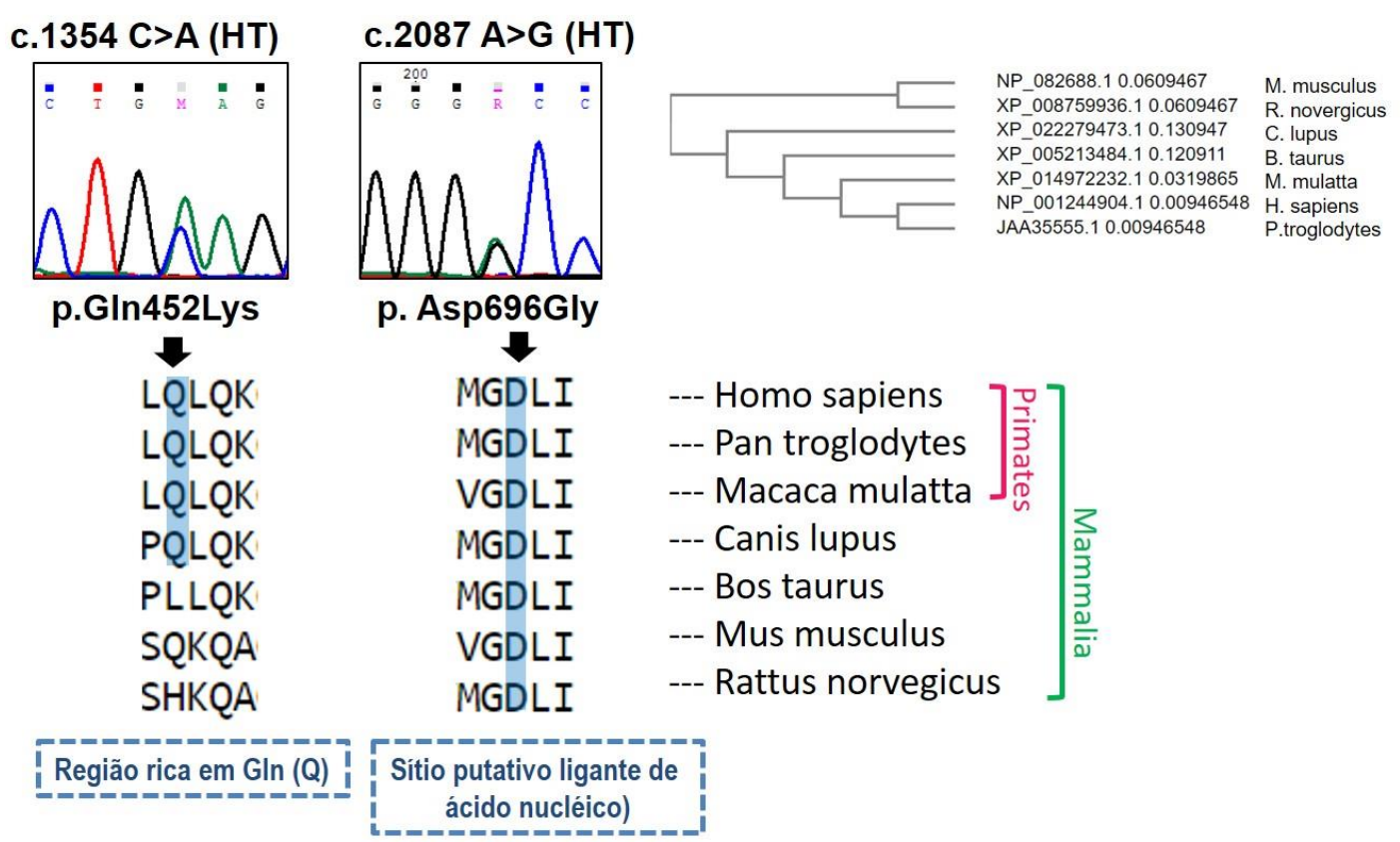

Acima, os eletroferogramas das variantes c.1354C >A (à esquerda) e c.2087A $>G$ (à direita), ilustram a troca dos nucleotídeos citosina (pico azul) por adenina (pico verde) e de adenina (pico verde) por guanina (pico preto), ambos em heterozigose. Abaixo, os trechos das sequências de aminoácidos da proteína foram alinhados com as mesmas sequências de diversas espécies, demonstrando que o aminoácido glutamina (Gln) na posição 452, constituinte de uma região rica em glutaminas, foi conservado em primatas, enquanto o aminoácido aspartato (Asp) na posição 696 foi conservado em todas as espécies selecionadas.

Figura 35. Variantes no gene ClZ1

$\mathrm{Na}$ variante p.Gln452Lys, os aminoácidos glutamina e lisina envolvidos possuem tamanho semelhante (128,14 Da e 128,17 Da), são polares mas possuem cargas diferentes (neutra e positiva). Já descrita no banco de dados gnomAD (frequência de 0,0009), essa variante foi predita como benigna de baixo impacto por todos os algoritmos (escore: Polyphen2 0.023, SIFT 0.39, Mutation Taster 0.99, PROVEAN -0.49 e CADD 10.8). 
Já na variante p.Asp696Gly, os aminoácidos possuem características diferentes em todos os aspectos. O aspartato possui tamanho de 115,09 Da e é polar de carga negativa, enquanto a glicina possui tamanho de 57,05 Da e é apolar de carga neutra. Além disso, essa variante também estava descrita no banco de dados gnomAD (frequência de $0.0007 \%$ ) mas foi predita pelos algoritmos in silico como prejudicial à função proteica e com impacto moderado (escores: Polyphen2 0.998, SIFT 0.00, MutationTaster 0.99, PROVEAN -3.93 e CADD 28.3).

De todos os genes investigados nesse estudo, o gene ClZ1 é o que possui menor grau de conservação entre as espécies, com sequências ortólogas somente em mamíferos placentários (Boreoeutheria). O aminoácido glutamina, na posição 452, constitui uma região rica em glutamina da proteína e estava conservado parcialmente entre os mamíferos selecionados. Já o aminoácido aspartato na posição 696 constitui uma região ligante de nucleotídeo e estava conservado em todas as espécies de mamíferos selecionadas (Figura 35).

Assim como nos outros genes, análise por modelagem molecular não foi possível, devido à falta de estruturas moldes, elucidadas experimentalmente, que apresentassem homologia à proteína em questão.

\subsubsection{GNAL}

c.658G>T:(p.Asp220Tyr). A troca do nucleotídeo guanina (G) por timina / uracila (T/U) na posição 658 do RNAm leva à troca da trinca GAU por UAU, alterando os aminoácidos aspartato (Asp) por tirosina (Tyr) na posição 220 da proteína Gaolf, durante o processo de tradução. Esses aminoácidos envolvidos diferem quimicamente, onde o aspartato é polar de carga negativa $(115,09 \mathrm{Da})$ e a tirosina é apolar de carga neutra (163.18 Da) (Figura 36).

GNAL:c.731A>G:(p.Glu244Gly). Da mesma forma, a troca do nucleotídeo adenina $(A)$ por guanina $(G)$ na posição 731 leva à troca da trinca GAA por GGA, alterando os aminoácidos glutamato (Glu) por glicina (Gly) na posição 244. Nessa variante, os aminoácidos envolvidos são completamente diferentes, o glutamato, de tamanho 129,12 Da é polar de carga negativa, enquanto a glicina, de tamanho 57.05 Da é apolar de carga neutra (Figura 36). 
GNAL:c.910G>A:(p.Asp304Asn). Por fim, a troca do nucleotídeo guanina $(\mathrm{G})$ por adenina $(\mathrm{A})$ na posição 910 do RNAm leva à troca da trinca GAU por AAU, alterando os aminoácidos aspartato (Asp) por asparagina (Asn) na posição 304 (Figura 36). Como na variante anteriormente citada, o aspartato é polar de carga negativa e tamanho de 115,09 Da e a asparagina é polar de carga neutra com 114,11 Da.

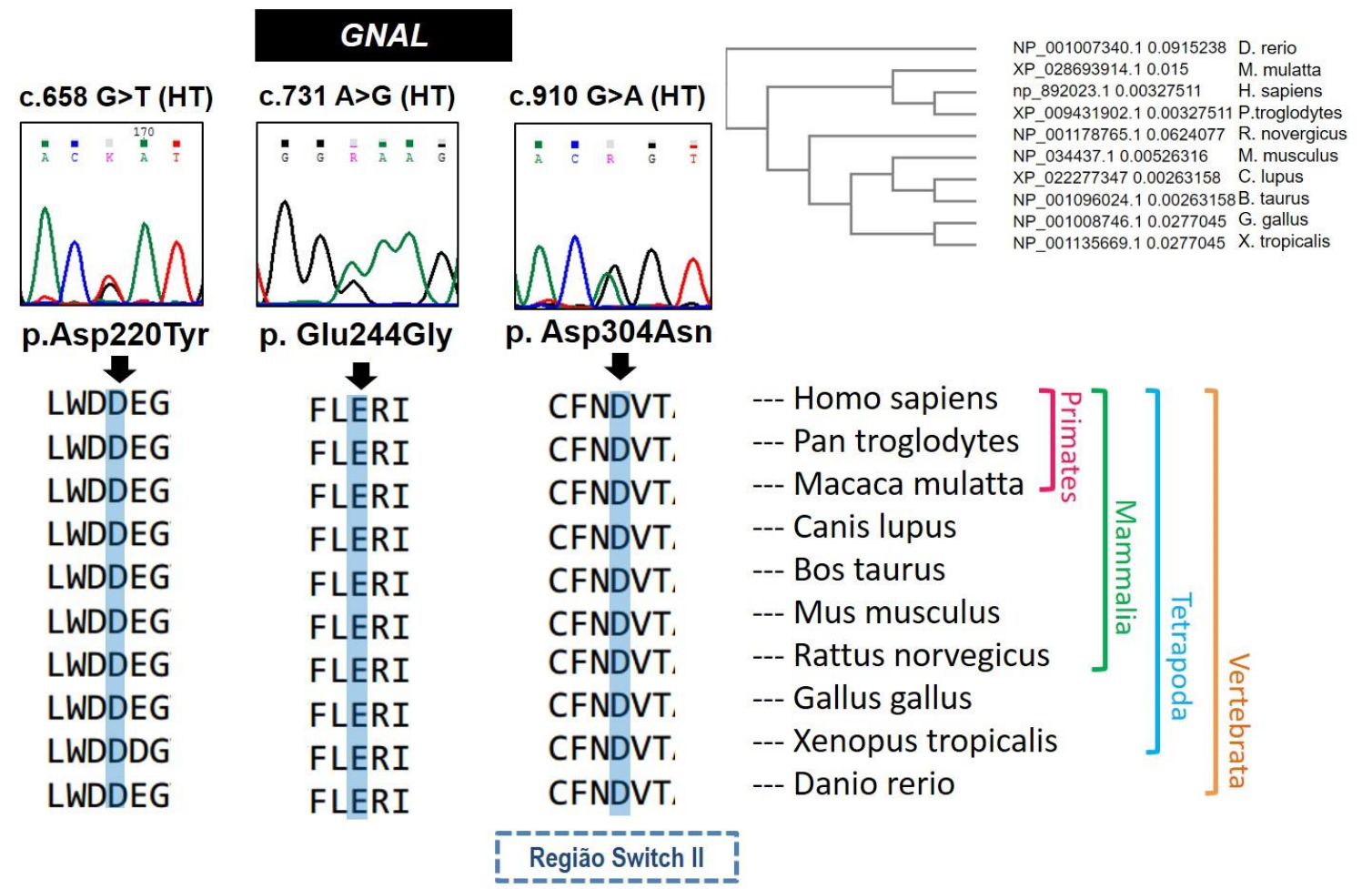

Acima, os eletroferogramas das variantes $c .658 G>T$, c.731A $>G$ e $c .910 G>A$, ilustram a troca dos nucleotídeos guanina (pico preto) por timina (pico vermelho), adenina (pico verde) por guanina (pico preto) e guanina por adenina, todos em heterozigose. Os trechos das sequências de aminoácidos da proteína GNAL foram alinhados com as mesmas sequências de diversas espécies, demonstrando que 0 aminoácido aspartato na posição 220 foi conservado em todas as espécies selecionadas, enquanto os aminoácidos glutamato e aspartato nas posições 244 e 304 foram conservados somente nos vertebrados. O aminoácido aspartato na posição 304 constitui uma região Switch II da proteína.

Figura 36. Variantes no gene GNAL

Nenhuma das variantes estava descrita nos bancos de dados consultados, e todas foram preditas como prejudiciais à função proteica, com impacto forte ou moderado pelas análises in silico. Variante p.Asp220Tyr escore: Polyphen2 1.00, SIFT 0.00, Mutation Taster 0.99, PROVEAN -8.54 e CADD 34. Variante p.Glu244Gly escore: Polyphen2 0.388, SIFT 0.002, Mutation Taster 0.99, PROVEAN 3.30 e CADD 25.7. Variante p.Asp304Asn escore: Polyphen2 0.029, SIFT 0.414, Mutation Taster 0.99, PROVEAN -4.48 e CADD 21.8. 
O gene GNAL se manteve conservado em vertebrados, com ortólogos nas espécies selecionadas, onde os resíduos Asp220, Glu244 e Asp304 se mantiveram conservados (Figura 36).

$\mathrm{Na}$ análise molecular, $81 \%$ dos resíduos foram modelados com mais de $90 \%$ de confiança. A estrutura molde selecionada foi a c6eg8L, corresponde à proteína Gas (PDB 6EG8), elucidada recentemente por meio da técnica de difração de raios $x$, com resolução de $2.8 \AA{ }^{(180)}$

Os modelos estavam adequados segundo análise de qualidade, sem nenhuma região de choque entre cadeias laterais. Conforme análise de Ramachandran, três aminoácidos prolina nas posições 149, 182 e 200 estavam em regiões desfavoráveis da proteína, indicando problemas nas angulações desses resíduos.

A proteína Gaolf possui sítios de ligação de GTP e magnésio, regiões de interação com complexo $\beta$ y (as outras subunidades da proteína G), regiões de interação com a proteína efetora adenilato ciclase e com o receptor putativo, além de regiões que sofrem alterações conformacionais mediante ligação de GTP. A estrutura molde utilizada na modelagem foi obtida em seu estado livre de ATP, ou seja, no estado inativo da proteína G. No seu estado inativo, Gaolf encontra-se ligada ao receptor e às subunidades $\beta y$, sem interagir com a proteína adenilato ciclase. Portanto, os modelos gerados demonstraram uma maior exposição dos sítios de interação com o receptor, assim como o sítio ativo ligante de GTP e a região de interação com as subunidades ßy. Além disso, a região GoLoco, capaz de manter as subunidades desassociadas na ausência de ativação também estava exposta (Figura 37). 

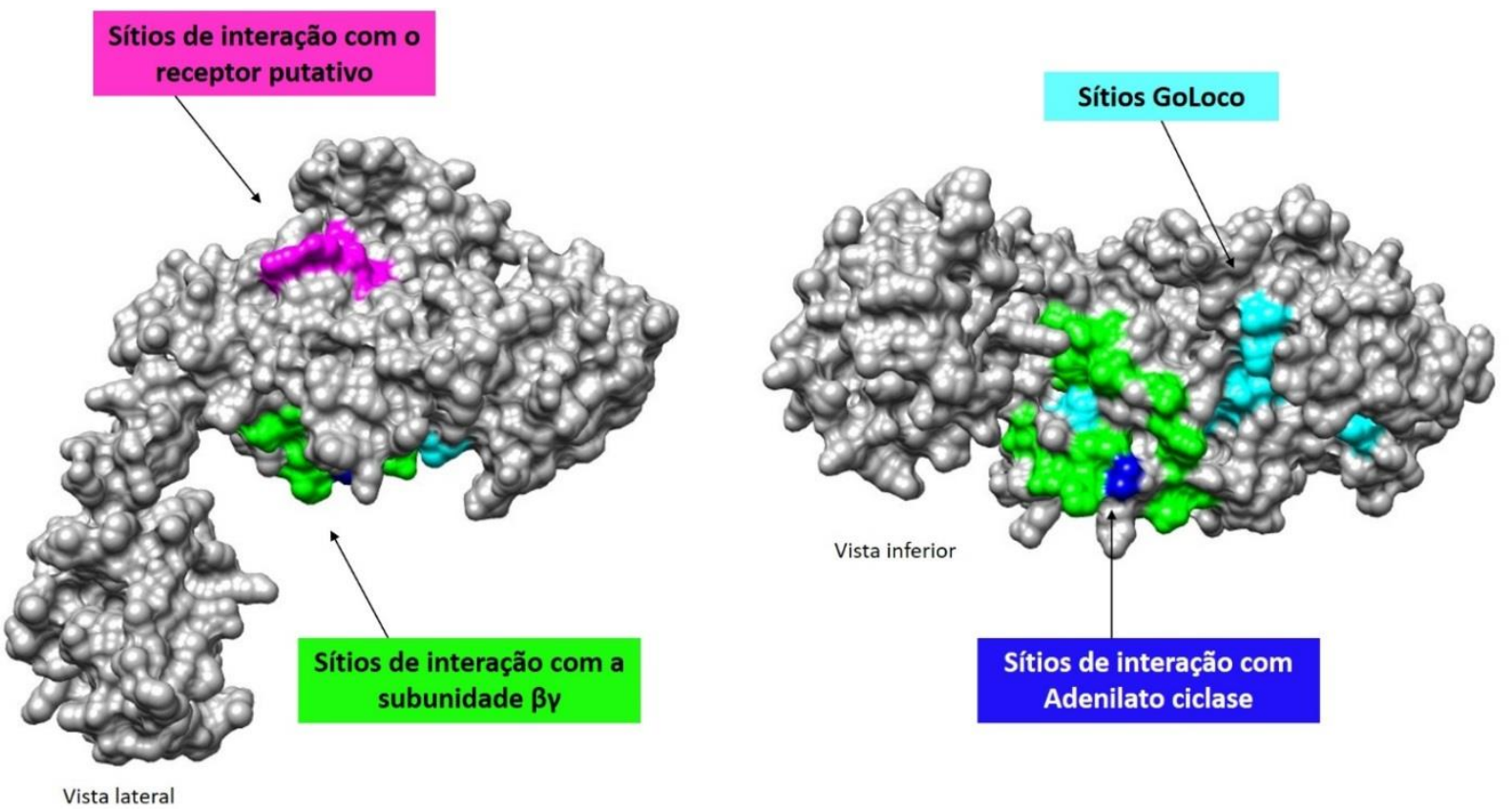

Vista lateral e inferior da estrutura do modelo selvagem da proteína Gaolf. Os sítios de interação com o receptor putativo (cor magenta), com as subunidades $\beta y$ (cor verde), com a proteína adenilato ciclase (azul) e do motivo GoLoco (cor ciano) estão destacados.

Figura 37. Região de interações da proteína Gaolf com as subunidades $\beta \gamma$, com o receptor putativo e a proteína efetora adenilato ciclase

Conforme ilustrado na figura 38 , nos modelos preditos, os sítios ligantes de GTP constituíram um poro centralizado na proteína Gaolf, dentro do domínio de interação da proteína com o receptor putativo.

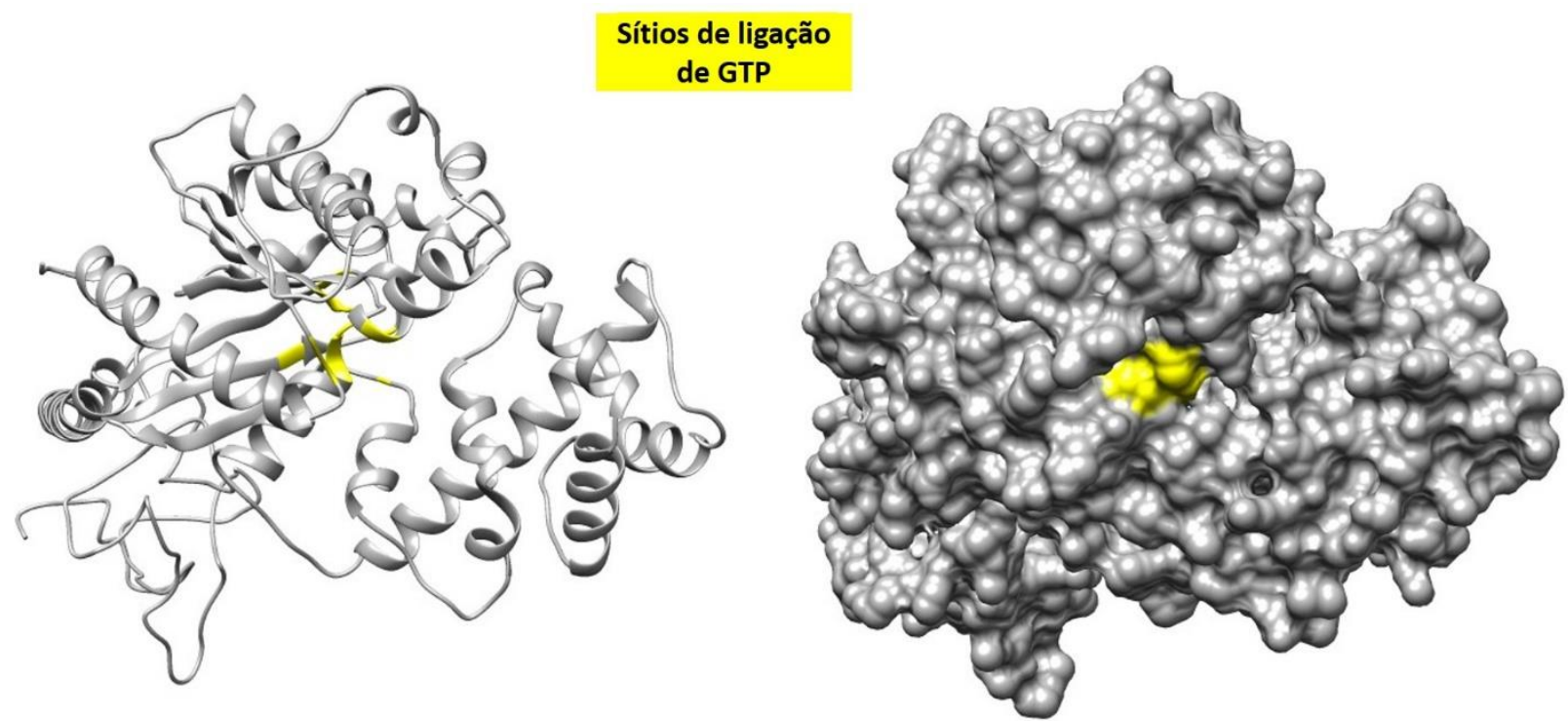

Os sítios ligantes de GTP estão representados em amarelo nas estruturas em fita (esquerda) e superfície (direita), demonstrando a formação de um poro centralizado na proteína (visão superior do modelo).

Figura 38. Sítios ligantes de GTP na proteína Gaolf (GNAL) 
Gaolf possui regiões de alterações conformacionais mediante sua ativação por GTP. Essas regiões constituem dois loops na porção superior da proteína (próximos à região de interação com o receptor) e dois loops na região inferior da proteína (próximos à região de interação com as subunidades $\beta y$ quando inativada) (Figura 39).

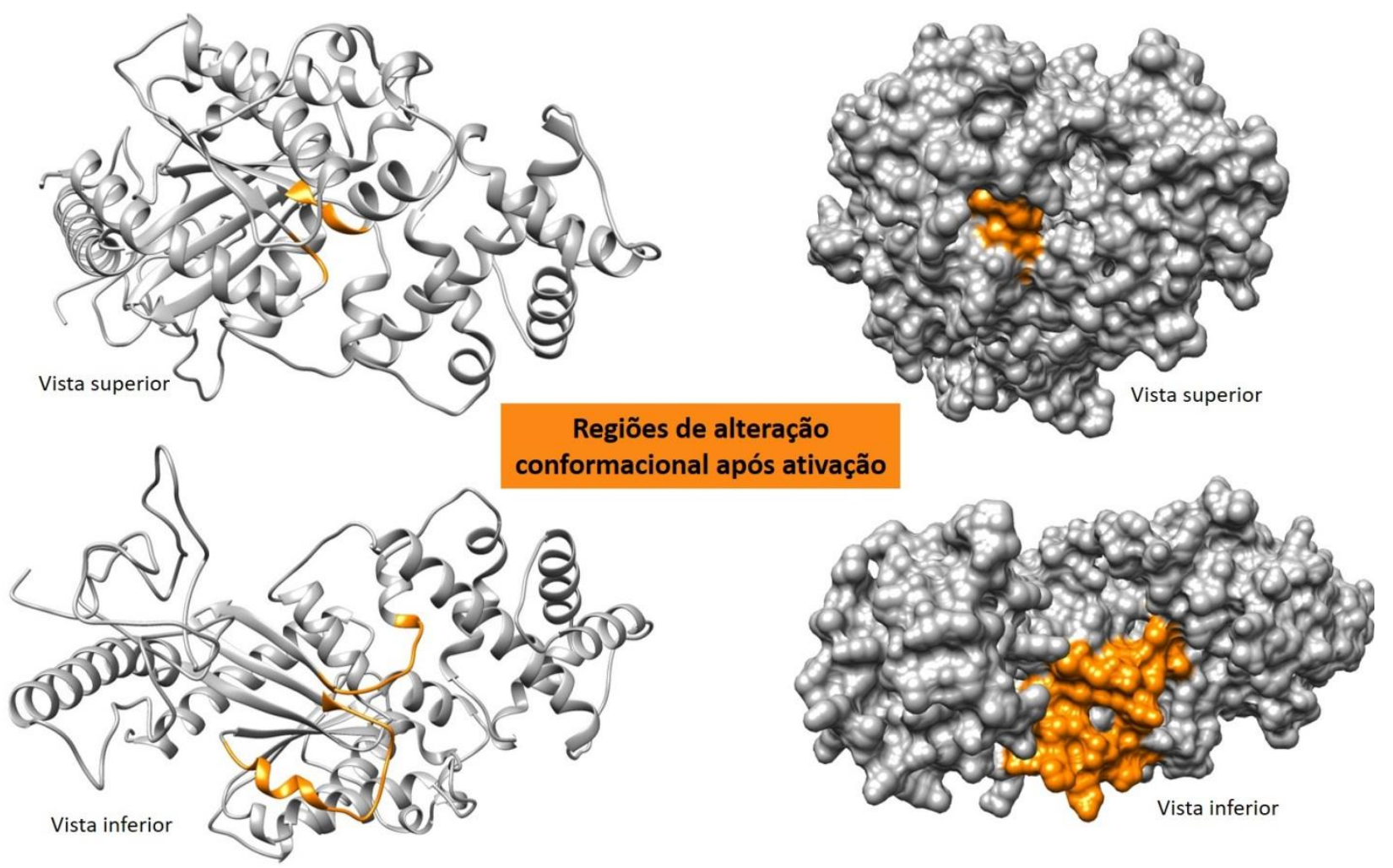

Figura 39. Regiões de alterações conformacionais na proteína Gaolf mediante ativação por GTP

Em relação ao modelo selvagem, a variante p.Asp220Tyr provocou a perda de todas as interações entre a $\alpha$-hélice 6 , a $\alpha$-hélice 14 e os loops entre as ahélices 13-14 e 3-4 no modelo variante (Figura 40). 
Modelo selvagem

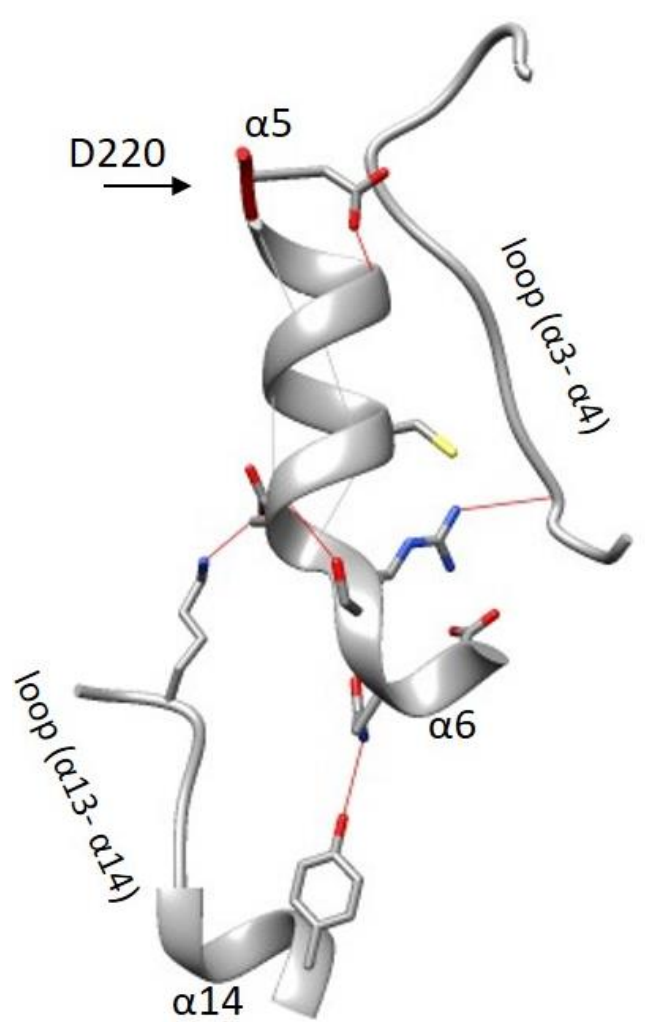

Modelo variante p.D220Y

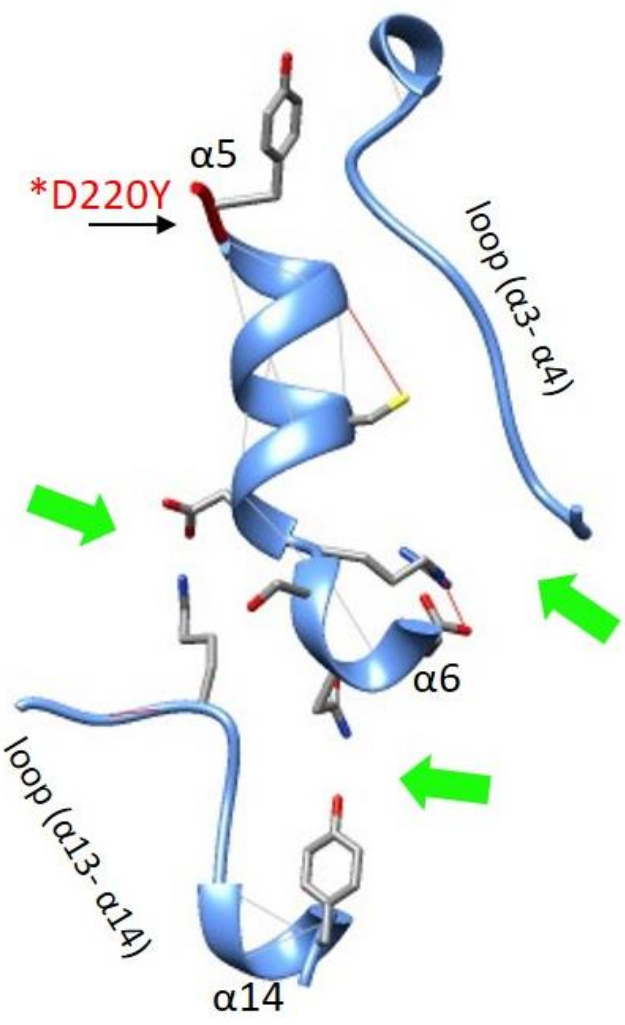

O resíduo 220 selvagem (à esquerda) e variante p.Asp220Tyr (à direita) está destacado na cor vermelha. Estrutura de $\alpha$-hélice $(\alpha)$ e fita $\beta$-pregueada $(\beta)$ estão indicadas conforme posição sequencial na estrutura primária da proteína. As linhas vermelhas indicam ligações por pontes de hidrogênio e as setas verdes indicam os locais de interação onde essas pontes foram perdidas.

Figura 40. Consequências moleculares na interação entre estruturas secundárias no modelo proteico GNAL com a variante p.Asp220Tyr

Ao analisar as ligações entre outras regiões da proteína, identificamos redes de interação mais abrangentes, com alterações em comum nos modelos variantes. Tais redes de interação estão exemplificadas na figura 41. 


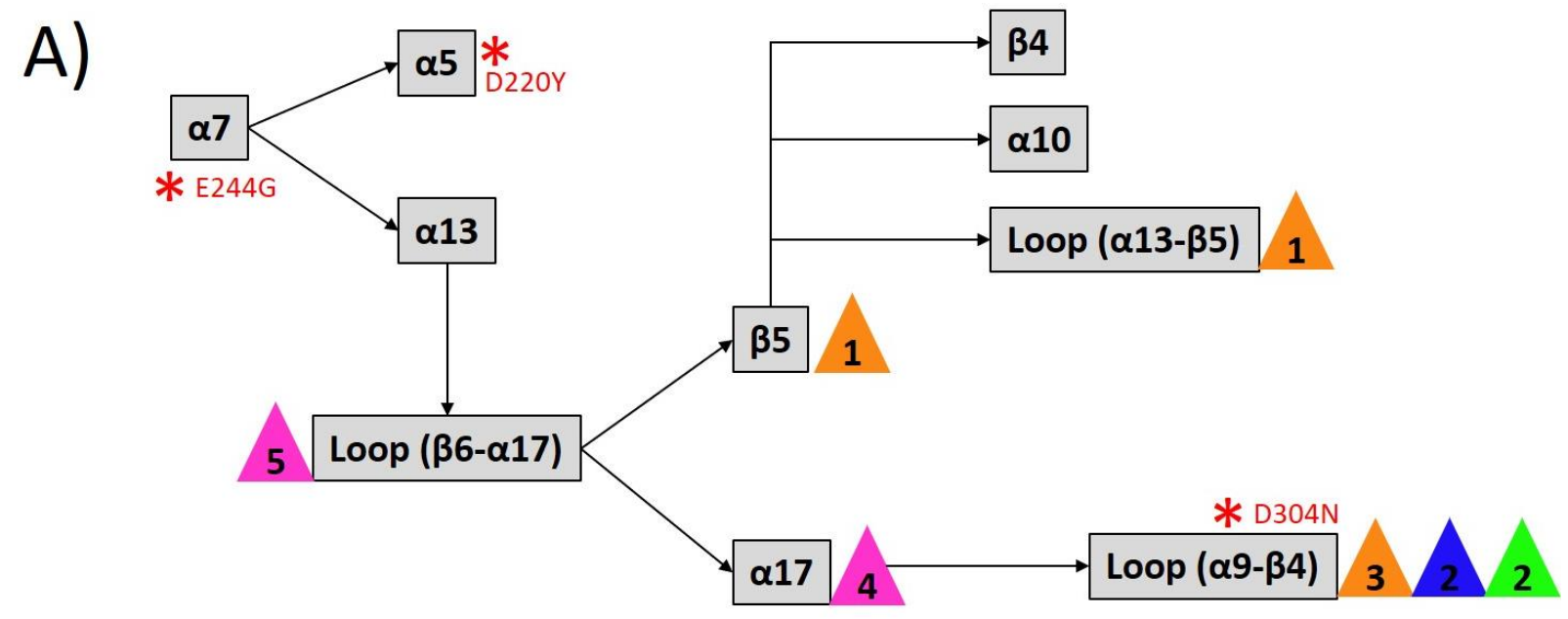

B)

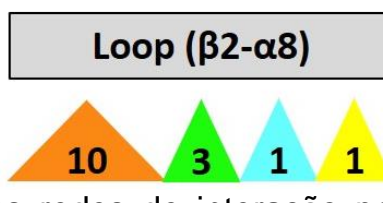

\section{Loop ( $\alpha 9-\beta 3)$}

11

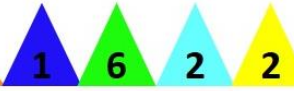

llustração das redes de interação por pontes de hidrogênio entre estruturas secundárias da proteína Gaolf. As setas indicam interação entre as estruturas. $\alpha$-hélice ( $\alpha$ ), fita $\beta$-pregueada $(\beta)$. O símbolo asterisco em vermelho (*) indica as regiões onde estão localizadas as variantes. O símbolo triangulo indica a presença e quantidade de resíduos que atuam como sítios de interação da proteína Gaolf com o receptor putativo (cor magenta), com as subunidades $\beta y$ (cor verde), com a proteína adenilato ciclase (azul), nas regiões de alterações conformacionais após ligação de GTP (laranja), sítios ativos ligantes de ATP (cor amarela) e sítios GoLoco (em ciano).

Figura 41. Esquema representativo da interação entre as estruturas secundárias da proteína Gaolf

Em relação ao modelo proteico selvagem, os três modelos variantes perderam a ponte de hidrogênio de interação das a-hélices 5 e 7 (Figura 42A). O modelo D220Y também perdeu as duas ligações entre a $\alpha$-hélice 17 e o loop a9ß4 (Figura 42B), enquanto os outros dois modelos perderam somente uma. 
Modelo selvagem

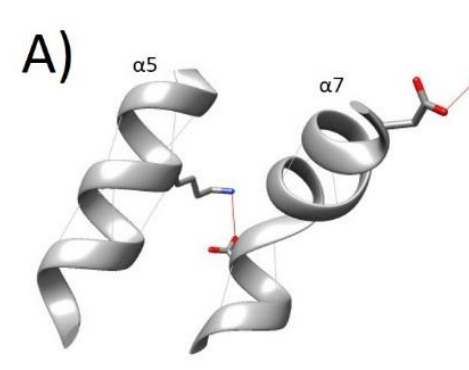

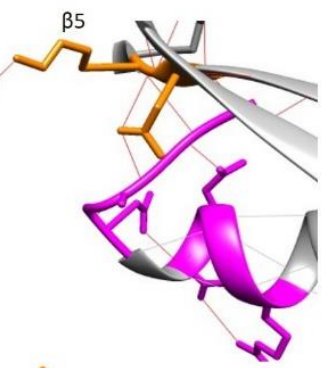

B)

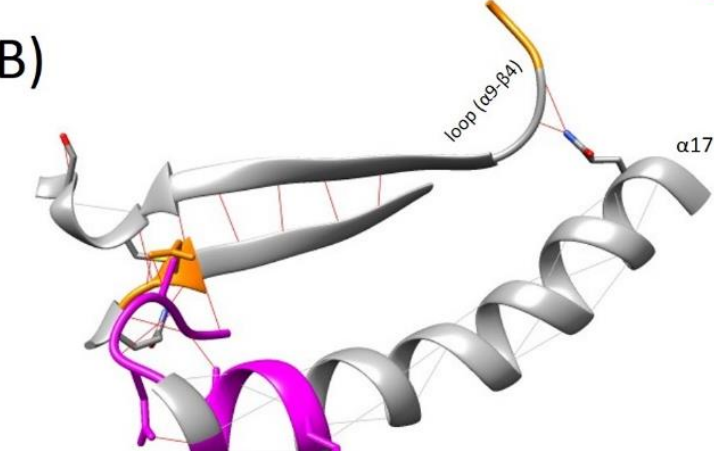

As regiões de alteração conformacional da proteína e de interação com o receptor putativo estão destacadas (respectivamente, cor laranja e magenta). As setas verdes indicam os locais onde houve perda de pontes de hidrogênio (linhas vermelhas). Estrutura secundária $\alpha$-hélice ( $\alpha$ ) e $\beta$-pregueada ( $\beta$ ).

Figura 42. Perda de interações entre as $\alpha$-hélices e loop da proteína Gaolf

Ao avaliar as ligações estabelecidas pela fita $\beta 5$, identificamos perda de pelo menos duas pontes de hidrogênio estabelecidas com a $\alpha$-hélice 10 e o loop $\alpha$ 17-ß6 (Figura 43). Ademais, o mesmo modelo perdeu duas interações entre os loops que sofrem alterações conformacionais após ativação da proteína (Figura 44). 


\section{Modelo selvagem}

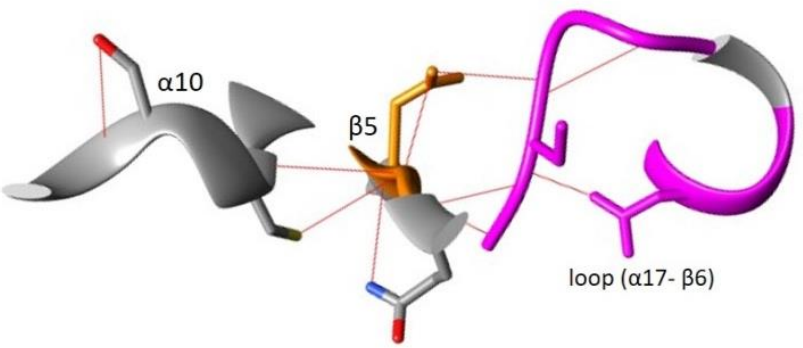

Modelo p.D220Y

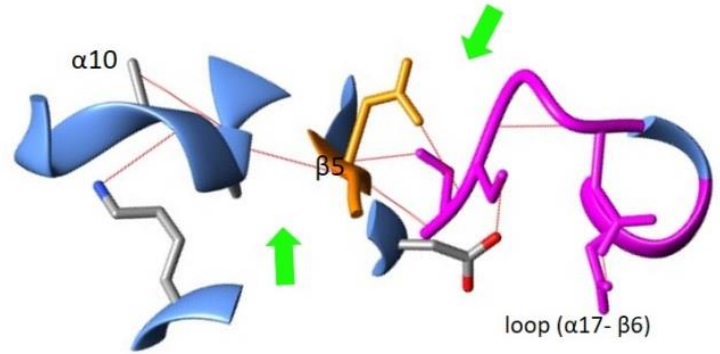

Regiões de alteração

conformacional após ativação receptor putativo

As regiões de alteração conformacional da proteína e de interação com o receptor putativo estão destacadas (respectivamente, cor laranja e magenta). As setas verdes indicam os locais onde houve perda de pontes de hidrogênio (linhas vermelhas). Estrutura secundária $\alpha$-hélice $(\alpha)$ e $\beta$-pregueada $(\beta)$.

Figura 43. Perda de interações da fita $\beta$-pregueada 5 da proteína Gaolf

\section{Modelo selvagem}
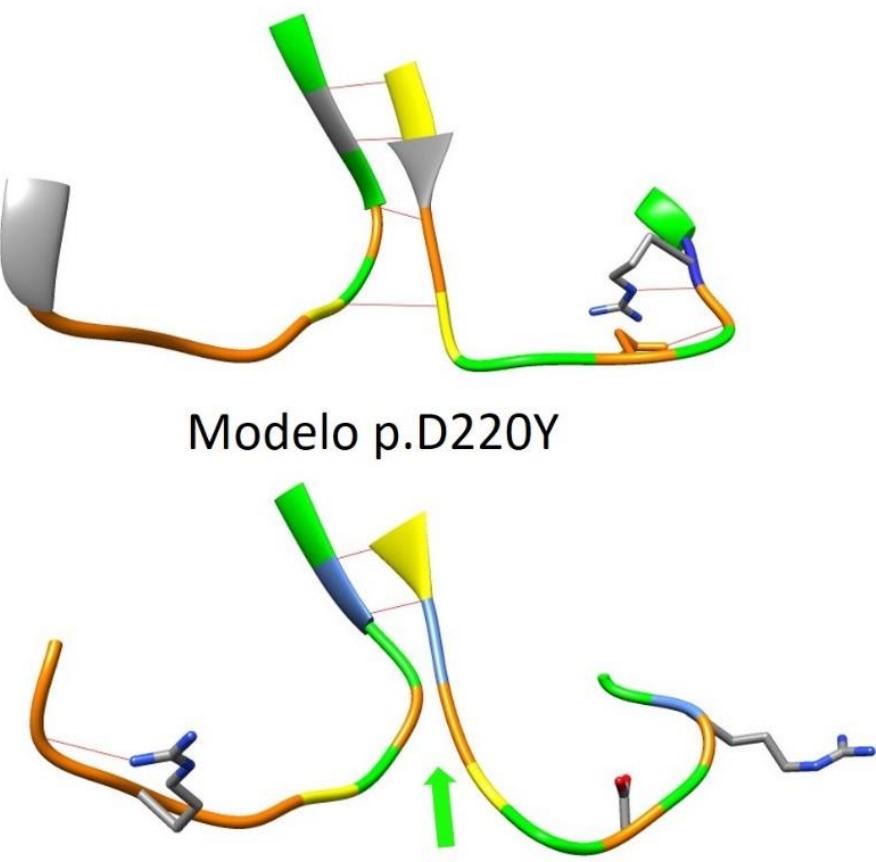

Sítios de interação com a subunidade $\beta y$

\section{Sítios de interação com}

Adenilato ciclase

Regiões de alteração conformacional após ativação

Sítios de ligação

de GTP

As setas verdes indicam os locais onde houve perda de pontes de hidrogênio (linhas vermelhas). Estrutura secundária $\alpha$-hélice $(\alpha)$ e $\beta$-pregueada $(\beta)$.

Figura 44. Perda de interações entre loops de alteração conformacional após ativação da proteína Gaolf

Os modelos das variantes p.E244G e p.D302N não demonstraram alterações nas regiões dos loops que sofrem alterações conformacionais mediante 
ativação. Assim como no 220, as interações entre a5 e a7 foram perdidas. A ligação do a7 - b5 e do loopa9-b4-a17 foram preservadas.

\subsubsection{KCTD17}

c.337G>A:(p.Glu113Lys) e c.655G>A:(p.Glu219Lys). A troca dos nucleotídeos guanina $(G)$ por adenina $(A)$ na posição 337 e 655 do RNAm leva à troca das trinca GAG por AAG, alterando os aminoácidos glutamato (Glu) por lisina (Lys) nas posições 113 e 219 da proteína KCTD17, durante o processo de tradução (Figura 45).

\section{KCTD17}
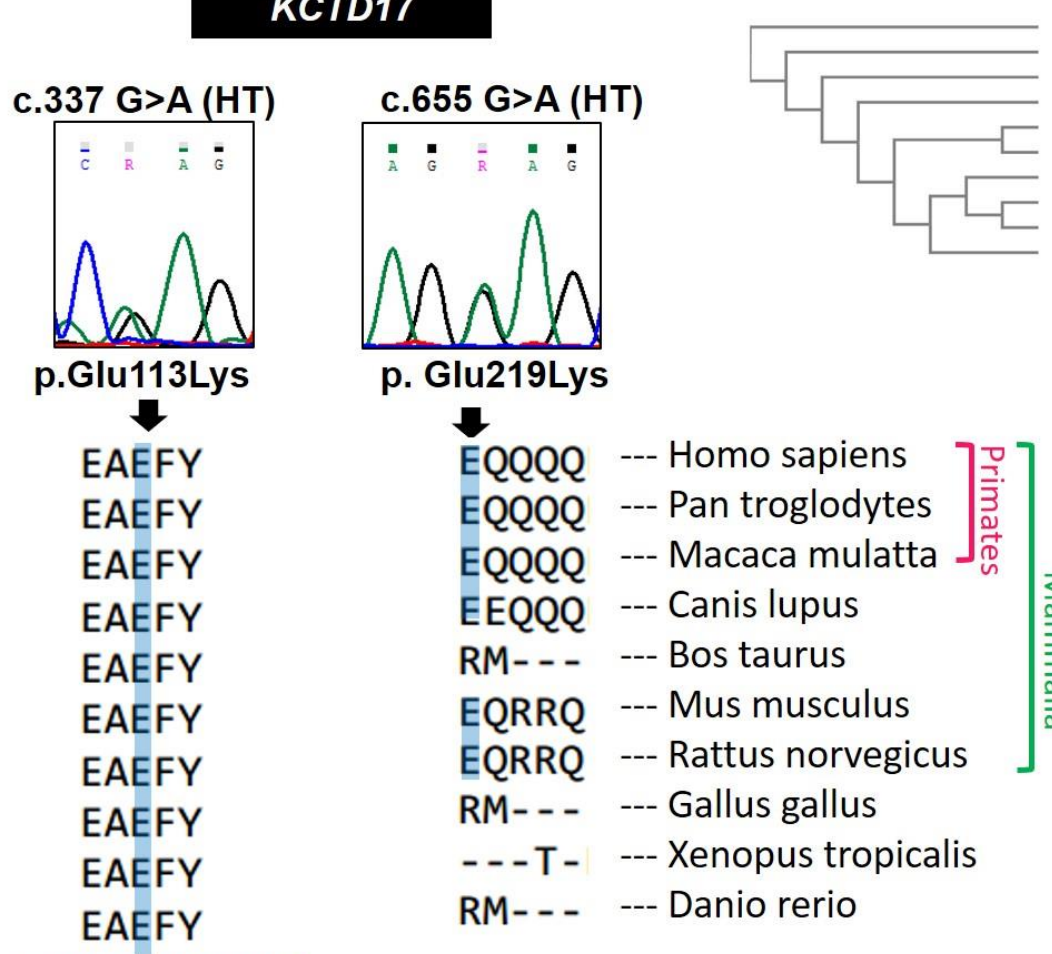

XP_004913948.1 0.279376 X. tropicalis $X P$ 005626277.1 0.257682 C. lupus $\begin{array}{lll}X P \_005156237.10 .213641 & \text { D. rerio }\end{array}$ NP_004937818.2 0.129429 G. gallus NP_001074836.2 0.0304878 M. musculus NP_001128001.1 0.0304878 R. novergicus NP_001252736.1 0.0159933 M. mulatta NP_.001252736.10.0159933 M. mulata NP_001269613.10 H. sapiens $\begin{array}{ll}\text { XP_001160046.1 } & \text { P.troglodytes } \\ \text { NP_001098907.1 0.0360577 } & \text { B. taurus }\end{array}$ p. Glu219Lys

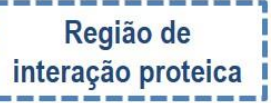

$\left.\begin{array}{ll}\text { EQQQQ } & -- \text { - Homo sapiens } \\ \text { EQQQQ } & -- \text { Pan troglodytes } \\ \text { EQQQQ } & -- \text { Macaca mulatta } \\ \text { EEQQQ } & -- \text { Canis lupus } \\ \text { RM--- } & -- \text { - Bos taurus } \\ \text { EQRRQ } & -- \text { Mus musculus } \\ \text { EQRRQ } & -- \text { Rattus norvegicus } \\ \text { RM--- } & -- \text { - Gallus gallus } \\ ---T- & -- \text { Xenopus tropicalis } \\ \text { RM--- } & -- \text { - Danio rerio }\end{array}\right]$

Acima, os eletroferogramas das variantes c.337G >A (à esquerda) e c.655G $>$ A (à direita), ilustram a troca dos nucleotídeos guanina (pico preto) por adenina (pico verde) nas duas variantes, e em heterozigose. Os trechos das sequências de aminoácidos da proteína KCTD17 foram alinhados com as mesmas sequências de diversas espécies, demonstrando que o aminoácido glutamato (Glu) na posição 113, o qual compõe uma região de interação proteica, foi conservado nos vertebrados, enquanto o da posição 219 foi parcialmente conservado nos mamíferos.

Figura 45. Variantes no gene KCTD17

Os dois aminoácidos envolvidos são polares e semelhantes em relação ao tamanho (129,12 e 128,17 Da), mas possuem cargas distintas (negativa e positiva). A variante p.Glu113Lys não foi identificada em nenhum banco de dados e foi 
predita como prejudicial (Polyphen2, escore 0.986; SIFT, escore 0.025; PROVEAN, escore -3.97), causadora de doença (MutationTaster, escore 0.99) e de forte impacto na função proteica (CADD escore 34). Já a variante p.Glu219Lys foi identificada no banco de dados gnomAD com frequência de 0,08\% e foi predita como benigna (Polyphen2, escore 0.002), prejudicial (SIFT, escore 0.043), polimorfismo (MutationTaster, escore 0.96), neutra (PROVEAN, escore 0.23) e de impacto moderado (CADD escore 19.79).

Por falta de homologia com estruturas já elucidadas experimentalmente, a modelagem molecular para essa proteína não foi realizada, uma vez que somente $46 \%$ dos aminoácidos foram alinhados.

\subsubsection{Achados secundários: MPPE1}

A variante c.911C>T resulta na alteração do aminoácido treonina por metionina na posição 304 da proteína (p.Thr304Met) e está descrita no banco de dados GnomAD com frequência inferior à 1\% (rs73945269). O aminoácido treonina na posição 304 foi conservado em vertebrados e não constitui um sítio ativo, porém, fica entre aminoácidos que atuam como sítios de ligação (resíduos 303 e 305). Análises in silico indicaram essa variante como prejudicial à função protéica (PROVEAN escore4.57, SIFT escore 0.001, MutationTaster escore 0.99, Polyphen2 escore 0.994) com impacto moderado (CADD escore 27).

A variante c.1022C>A provoca a substituição do aminoácido prolina por histidina na posição 341 da proteína (p.Pro341His), não conservada entre as espécies e que não constitui sítios ativos e região transmembrana. Análises in silico não foram concordantes. Foi identificada em um probando com uma variante no gene ATP1A3 (c.1472A>G / p.Asn491Ser). A filha assintomática portava a mesma variante no gene MPPE1 mas não portava a variante no gene ATP1A3.

Por outro lado, a variante c.1189T>A (p.X397Arg) leva à perda do códon indicar de término de transcrição, conservado em vertebrados, gerando uma proteína alterada e maior. Essa variante não foi encontrada em nenhum banco de dados populacional e análises in silico não foram úteis na predição do seu impacto.

Por fim, a variante c.413G>A (p.Arg138GIn) que também foi

identificada em heterozigose, estava descrita nos bancos de dados genéticos 
(rs11872520) com frequência de 0,8\%, e foi predita com impacto moderado na função proteica (CADD escore 26.2).

\subsection{Caracterização fenotípica dos probandos e correlação com o genótipo}

O fenótipo de cada probando está detalhado na tabela 3.

Ademais, as análises de patogenicidade de cada variante genética, assim como a correlação com os fenótipos estão resumidas na tabela 4 .

Em relação ao probando com a inserção no gene $D D C$ (c.568_569insCGATC), cabe citar que embora inicialmente tenha sido relatado resposta ao tratamento com levodopa, tal resposta não se manteve com o passar do tempo. 
Tabela 3. Fenótipo dos probandos com variantes genéticas

\begin{tabular}{|c|c|c|c|c|c|c|c|c|c|c|c|c|}
\hline $\mathbf{p}$ & Gene & Variante & Sexo & $\begin{array}{c}\text { Idade de } \\
\text { surgimento }\end{array}$ & $\begin{array}{c}\text { Duração } \\
\text { (anos) }\end{array}$ & Local de surgimento & Distribuição & HF & cs & L-DOPA & PK & MC \\
\hline 1 & TOR1A & c. $488 \mathrm{C}>\mathrm{T}$ & M & 25 & 2 & Língua & Focal & - & $\mathrm{D}$ & $\mathrm{D}$ & - & \\
\hline 2 & & c.907_909delGAG & M & 8 & 26 & Membro superior & Generalizada & S & - & $\mathrm{N}$ & - & \\
\hline 4 & & c. $607 \mathrm{G}>\mathrm{A}$ & $\mathrm{F}$ & 2 & 30 & Membro inferior & Multifocal & $P$ & - & $S$ & - & \\
\hline 5 & $\mathrm{TH}$ & c. $81 \mathrm{G}>\mathrm{T}$ & $\mathrm{F}$ & 24 & 1 & Membro superior & Focal & - & - & $\mathrm{D}$ & - & \\
\hline 8 & THAP1 & c. $289 \mathrm{C}>\mathrm{T}$ & M & 10 & 17 & Cervical & Segmentar & - & - & $D$ & - & \\
\hline 9 & & & M & 10 & 15 & Membro superior & Multifocal & $S$ & - & $\mathrm{N}$ & - & \\
\hline 10 & & & M & 18 & 6 & Cervical & Generalizada & - & - & $\mathrm{D}$ & - & \\
\hline 11 & & & M & 22 & 2 & Membro superior & Generalizada & - & - & $\mathrm{N}$ & - & \\
\hline 12 & & & M & 5 & 26 & Membro inferior & Generalizada & - & - & $\mathrm{N}$ & - & \\
\hline 17 & & & M & 8 & 17 & Membro superior & Multifocal & - & $S$ & $\mathrm{~N}$ & - & \\
\hline 18 & & & $\mathrm{~F}$ & 53 & 3 & $\begin{array}{l}\text { Membro superior e } \\
\text { cervical }\end{array}$ & Segmentar & - & - & $\mathrm{D}$ & - & \\
\hline 19 & & & M & 18 & 3 & cervical & Focal & - & - & $\mathrm{D}$ & - & \\
\hline 20 & & c. $795 \mathrm{C}>\mathrm{A} ; 665 \mathrm{C}>\mathrm{T}$ & $\mathrm{F}$ & 8 & 7 & Membro inferior & Generalizada & - & - & $\mathrm{N}$ & - & \\
\hline
\end{tabular}




\begin{tabular}{|c|c|c|c|c|c|c|c|c|c|c|c|c|}
\hline 21 & ClZ1 & c. $1354 \mathrm{C}>\mathrm{A}$ & $\mathrm{F}$ & 20 & 32 & $\begin{array}{l}\text { Membro superior e } \\
\text { cervical }\end{array}$ & Generalizada & $\mathrm{S}$ & - & $\mathrm{D}$ & - & - \\
\hline 22 & & c. $2087 A>G$ & $\mathrm{~F}$ & 27 & 3 & Cervical & Focal & - & - & D & - & s \\
\hline 24 & & c. $731 A>G$ & $\mathrm{~F}$ & 35 & 9 & Cervical & Focal & - & - & D & - & - \\
\hline 25 & KCTD17 & c. $337 G>A$ & $\mathrm{~F}$ & 19 & 32 & Cervical & Focal & S & - & D & - & - \\
\hline 26 & TUBB4A & c. $.883 G>A$ c. $2653 G>A$ & $M$ & 6 & 24 & Membro superior & Generalizada** & - & - & $\mathrm{N}$ & - & - \\
\hline \multirow[t]{2}{*}{27} & PRKRA & c. $665 \mathrm{C}>\mathrm{T}$ & M & 25 & 17 & Membro superior & Segmentar & $P$ & - & $\mathrm{N}$ & - & - \\
\hline & KCTD17 & c. $655 \mathrm{G}>\mathrm{A}$ & & & & & & & & & & \\
\hline \multirow[t]{2}{*}{28} & SGCE & c. $584 G>A$ & $\mathrm{~F}$ & 36 & 7 & Cervical & Focal & - & D & D & - & - \\
\hline & GNAL & c. $910 G>A$ & & & & & & & & & & \\
\hline
\end{tabular}

Probando (coluna P). História Familiar (HF): Não (-), Sim (S), Possível (P). Consanguinidade (CS): Não (-), Sim (S), Desconhecido (D). Resposta à levodopa (L$D O P A)$ : Sim (S), Não (N), Desconhecida (D). Parkinsonismo (PK): Não (-), Sim (S). Mioclonia (MC): Não (-), Sim (S). *Resposta parcial à levodopa.

${ }^{* *}$ Generalizada com envolvimento da laringe. 
Tabela 4. Conclusão das análises de patogenicidade e correlação dos genótipos com os fenótipos

\begin{tabular}{|c|c|c|c|c|c|c|c|c|c|}
\hline GENE & Variante genômica & $\begin{array}{l}\text { Variante } \\
\text { proteica }\end{array}$ & $\begin{array}{l}\text { Propriedades } \\
\text { químicas }\end{array}$ & $\begin{array}{c}\text { Grau de } \\
\text { conservação }\end{array}$ & $\begin{array}{c}\text { Bancos de } \\
\text { dados }\end{array}$ & $\begin{array}{l}\text { Domínio } \\
\text { funcional }\end{array}$ & Descrição & $\begin{array}{l}\text { Análises in } \\
\text { silico }\end{array}$ & $\begin{array}{c}\text { Correlação } \\
\text { fenótipo }\end{array}$ \\
\hline \multirow{2}{*}{ TOR1A } & c. $488 \mathrm{C}>\mathrm{T}$ & p.Ala163Val & Similares & Parcial & 0,08 & Sim & Incerta & Discordantes & $\mathrm{Sim}^{\mathrm{b}}$ \\
\hline & c.907_909delGAG & p.Glu303del & - & Alto & 0,01 & - & Patogênica & - & Sim \\
\hline \multirow{2}{*}{$\mathrm{GCH} 1$} & c. $439 \mathrm{C}>\mathrm{T}$ & p.Pro147Ser & Diferentes & Alto & - & Sim & - & Patogênica & Sim \\
\hline & c. $607 \mathrm{G}>\mathrm{A}$ & p.Gly203Arg & Diferentes & Alto & - & Não & Patogênica & Patogênica & Sim \\
\hline$D D C$ & c. $715 \mathrm{~A}>\mathrm{T}$ & p.Met239Leu & Similares & Baixo & - & Não & - & Benigna & Não \\
\hline THAP1 & c. $289 \mathrm{C}>\mathrm{T}$ & p.G $\ln 97^{*}$ & - & - & - & - & Patogênica & Patogênica & $\operatorname{Sim}^{b}$ \\
\hline \multirow[t]{2}{*}{ SGCE } & c. $584 G>A$ & p.Arg195His & Similares & Alto & 0,03 & Não & - & Discordantes & Não \\
\hline & c. $1472 A>G$ & p.Asn491Ser & Similares & Parcial & 0,02 & Não & - & Benigno & Não \\
\hline ATP1A3 & c. $2653 \mathrm{G}>\mathrm{A}$ & p.Val885lle & Similares & Parcial & 0,2 & Não & $\begin{array}{l}\text { Provavelmente } \\
\text { Benigna }\end{array}$ & Benigno & Não \\
\hline \multirow{2}{*}{$C l Z 1$} & c. $2087 A>G$ & p.Asp696Gly & Diferentes & Parcial & 0,0007 & Sim & - & Patogênica & Sim \\
\hline & c. $658 \mathrm{G}>\mathrm{T}$ & p.Asp220Tyr & Diferentes & Alto & - & Não & - & Patogênica & Sim \\
\hline \multirow[t]{2}{*}{ GNAL } & c. $731 \mathrm{~A}>\mathrm{G}$ & p.Glu244Gly & Diferentes & Parcial & - & Não & - & Patogênica & Sim \\
\hline & c. $910 \mathrm{G}>\mathrm{A}$ & p.Asp304Asn & Diferentes & Parcial & - & Sim & - & Patogênica & Sim \\
\hline \multirow{2}{*}{ KCTD17 } & c. $337 \mathrm{G}>\mathrm{A}$ & p.Glu113Lys & Diferentes & Parcial & 0,08 & Sim & - & Patogênica & Sim \\
\hline & c. $655 \mathrm{G}>\mathrm{A}$ & p.Glu219Lys & Diferentes & Baixo & 0,08 & Não & - & Benigna $^{a}$ & Nãoc \\
\hline
\end{tabular}

a- Pela maioria dos algoritmos $/{ }^{\mathrm{b}}$ - A maioria das características $/{ }^{\mathrm{c}}$ - o fenótipo correlacionou com o gene PRKRA onde o probando possui variante patogênica em homozigose. Grau de conservação: Alto: eucariotos; Parcial: vertebrados ou mamíferos; Baixo: primatas e nenhum. Descrição conforme estudos já publicados com a mesma variante ou pelo ClinVar. 
Conforme detalhado anteriormente, após análises de patogenicidade e correlação com o fenótipo, não identificamos evidências de patogenicidade suficientes para as variantes nos genes $T H(\mathrm{c} .81 \mathrm{G}>\mathrm{T}), A T P 1 A 3$ (c.1472A>G) e $D D C$ (c.715A $>\mathrm{T}$ ), uma em cada probando, e nem para as variantes $S G C E$ (c.585G>A), ATP1A3 (c.2653G $>A)$ e KCTD17 (c.655G>A), que foram identificadas concomitantemente com outras variantes. Portanto, nesse estudo, variantes genéticas potencialmente patogênicas estavam presentes em 25 probandos (16\%), as quais estão distribuídas por faixa etária na figura 46.

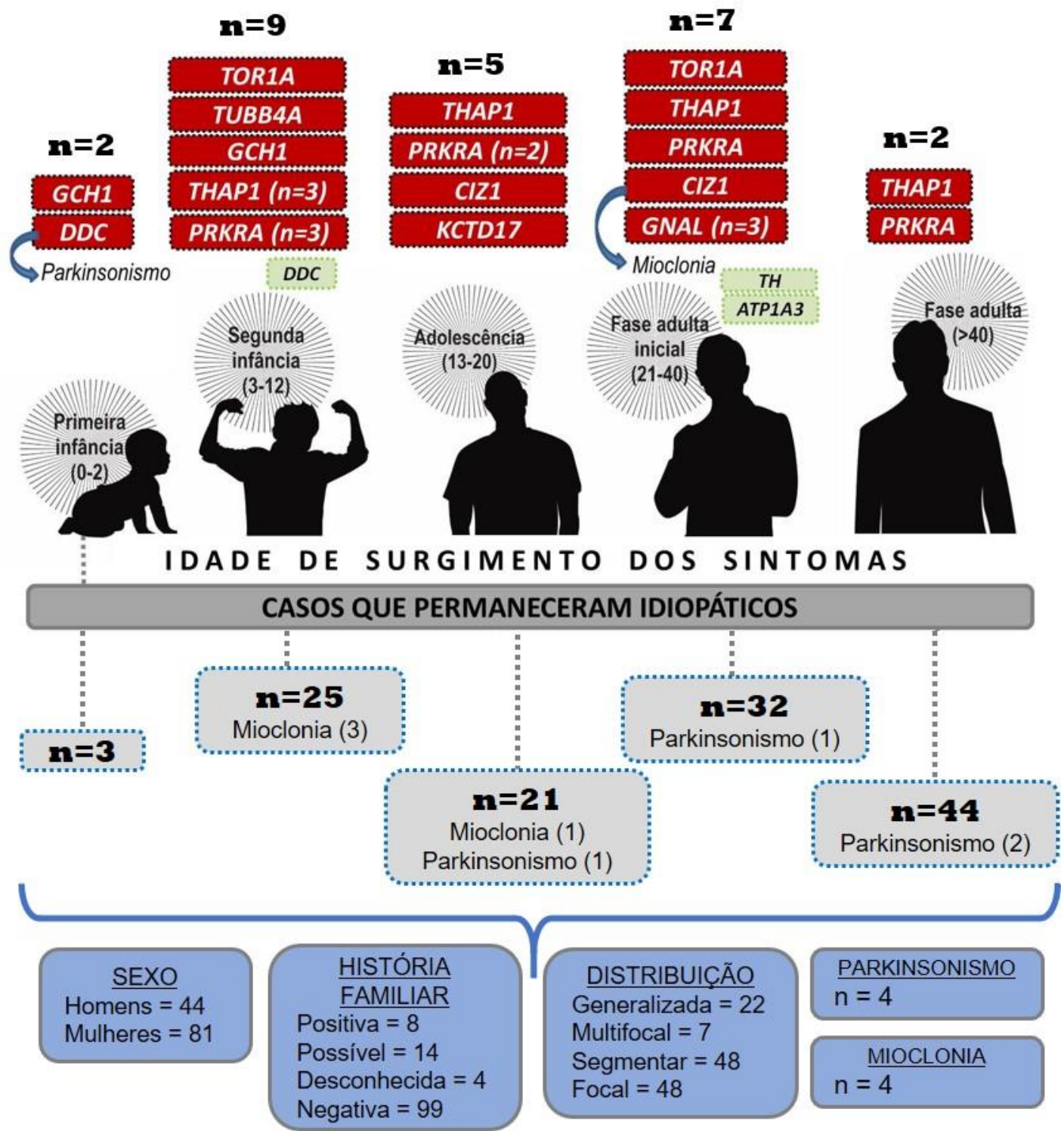

$\mathrm{N}$ (quantidade de probandos). Em vermelho estão ilustrados os genes com variantes potencialmente patogênicas e em verde estão os genes com variantes sem evidências de patogenicidade suficientes. Abaixo estão descritas as características fenotípicas dos probandos que permaneceram idiopáticos.

Figura 46. Distribuição das variantes genéticas potencialmente patogênicas e dos casos que permaneceram idiopáticos por faixa etária 
Além disso, variantes no gene MPPE1 (gene que não está descrito como causa de distonia) foram identificadas em 3 probandos do sexo feminino com acometimento cervical e surgimento dos sintomas entre 20 e 58 anos (Tabela 5).

Tabela 5. Características clínicas dos probandos com variantes no gene MPPE1

\begin{tabular}{|c|c|c|c|c|c|c|}
\hline $\mathbf{P}$ & Variante & Sexo & $\begin{array}{l}\text { Idade de } \\
\text { surgimento } \\
\text { (anos) }\end{array}$ & $\begin{array}{l}\text { Local de } \\
\text { surgimento }\end{array}$ & $\begin{array}{l}\text { Duração da } \\
\text { distonia } \\
\text { (anos) }\end{array}$ & Distribuição \\
\hline 1 & $\begin{array}{l}\text { c.911C>T } \\
\text { p.Thr304Met }\end{array}$ & $\mathrm{F}$ & 58 & Oromandibular & 4 & $\begin{array}{l}\text { Oromandibular e } \\
\text { Cervical }\end{array}$ \\
\hline 2 & $\begin{array}{l}\text { c. } 911 \mathrm{C}>\mathrm{T} \\
\text { p.Thr304Met }\end{array}$ & $\mathrm{F}$ & 20 & $\begin{array}{l}\text { Cervical e } \\
\text { membro inferior }\end{array}$ & 48 & $\begin{array}{l}\text { Cervical e membro } \\
\text { inferior }\end{array}$ \\
\hline 3 & $\begin{array}{l}\text { c. } 1022 \mathrm{C}>\mathrm{A} \\
\text { p.Pro341His }\end{array}$ & $\mathrm{F}$ & 35 & Cervical & 21 & $\begin{array}{l}\text { Tronco e } \\
\text { oromandibular }\end{array}$ \\
\hline 4 & $\begin{array}{l}\text { c. } 413 G>A \\
\text { p.Arg138Gln }\end{array}$ & $F$ & 40 & Cervical & 10 & Cervical \\
\hline 5 & $\begin{array}{l}\text { c. } 1189 \mathrm{~T}>\mathrm{A} \\
\text { p.X397Arg }\end{array}$ & $F$ & 7 & Cervical & 39 & $\begin{array}{l}\text { Cervical e todos os } \\
\text { membros }\end{array}$ \\
\hline
\end{tabular}

\subsection{Prevalência de cada causa genética}

A prevalência de cada causa genética está descrita na tabela 6 e ilustrada na figura 47. Além dos casos investigados aqui, consideramos os casos com diagnóstico genético prévio à realização desse estudo $(n=23)$, com variantes genéticas potencialmente patogênicas identificadas através do método de sequenciamento Sanger. ${ }^{(120,160)}$

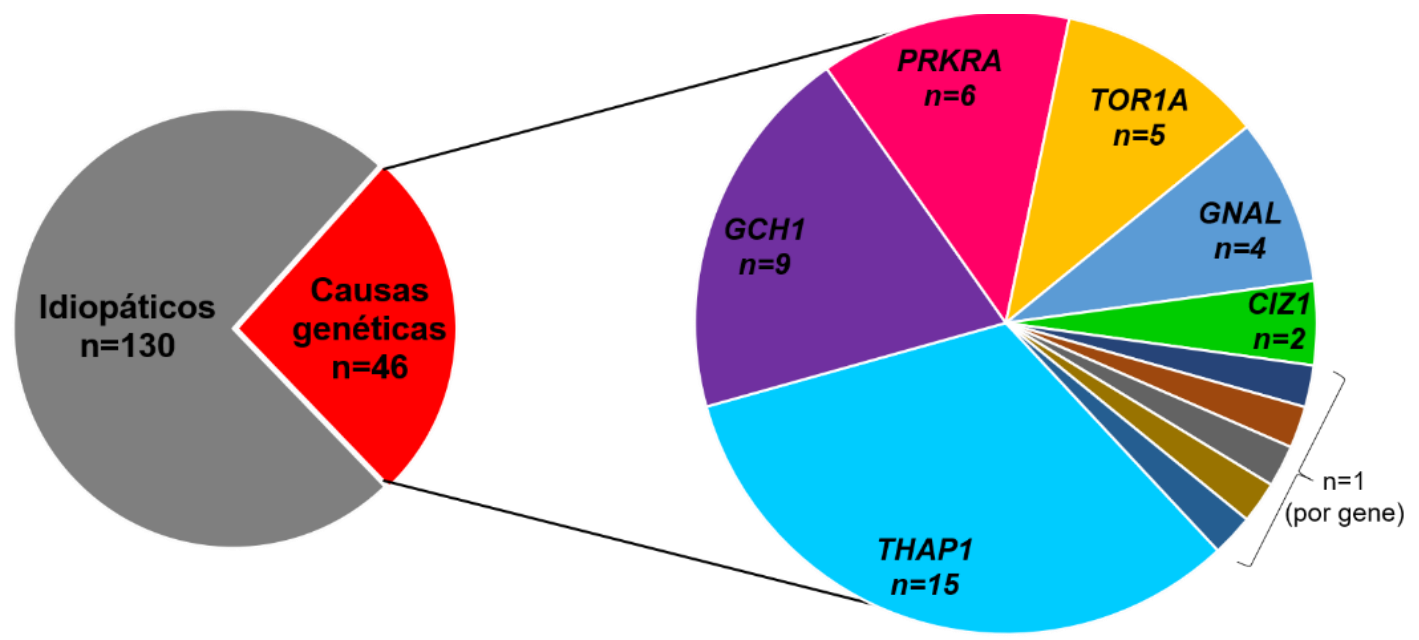

Quantidade de probandos afetados (n).

Figura 47. Frequência de cada causa genética de distonia no grupo amostral 
Tabela 6. Frequência total de cada causa genética conforme método de identificação

\begin{tabular}{|c|c|c|c|}
\hline \multirow{2}{*}{ Gene } & \multicolumn{2}{|c|}{ Método } & \multirow{2}{*}{$\begin{array}{c}\text { Total afetados } \\
\mathrm{n}(\%)\end{array}$} \\
\hline & Sanger & NGS & \\
\hline TOR1A & 3 & 2 & $5(2,84)$ \\
\hline TUBB4A & - & 1 & $1(0,56)$ \\
\hline $\mathrm{GCH} 1$ & 7 & 2 & $9(5,11)$ \\
\hline $\mathrm{TH}$ & 1 & - & $1(0,56)$ \\
\hline$D D C$ & - & 1 & $1(0,56)$ \\
\hline THAP1 & $10(120)$ & 5 & $15(8,52)$ \\
\hline$S G C E$ & 1 & - & \\
\hline PRKRA & - & 6 & $6(3,4)$ \\
\hline$C / Z 1$ & - & 2 & $2(1,13)$ \\
\hline GNAL & $1(160)$ & 3 & $4(2,27)$ \\
\hline KCTD17 & - & 1 & $1(0,56)$ \\
\hline Subtotal & 23 & 23 & $46(26,13)$ \\
\hline Idiopáticos & & & $130(73,86)$ \\
\hline TOTAL & 23 & 23 & $176(100)$ \\
\hline
\end{tabular}

${ }^{*}$ Considerando um total de 176 probandos (153 investigados pelo método de NGS somados com 23 probandos investigados previamente à realização desse estudo).

Dos 130 probandos que permaneceram classificados como idiopáticos, cinco possuíam variantes genéticas que não demonstraram evidências de patogenicidade (genes $T H,=1, D D C=1, K C T D 17=1$ e $A T P 1 A 3=2$ ). 


\section{DISCUSSÃO}

Nesse estudo, variantes genéticas potencialmente patogênicas foram identificadas em 25 dos 153 indivíduos com distonia idiopática. Embora grande parte da amostra seja composta por indivíduos com distonia de surgimento na fase adulta, a maioria das variantes foram identificadas na infância, adolescência e fase adulta inicial, indicando que hoje, análises genéticas por painel são mais úteis no diagnóstico de distonia com início precoce. A seguir, discutimos o impacto de cada variante na função proteica e no fenótipo dos probandos investigados.

\subsection{TOR1A}

Identificamos variantes TOR1A, em heterozigose, em dois probandos do nosso grupo amostral. Considerando esses casos, somados aos casos com diagnóstico prévio, 2,8\% dos casos recrutados pela rede RBED possuem distonia causada por variantes nesse gene (5 afetados / 176 total investigados).

A deleção patogênica c.907_909delGAG / p.Glu303del no éxon 5, já está descrita na literatura como patogênica e frequentemente é relatada em distonia DYT-TOR1A, na qual contribui para aproximadamente $50 \%$ dos casos. ${ }^{(181)}$ No presente estudo, essa variante foi encontrada em um probando com fenótipo característico de DYT-TOR1A. ${ }^{(79,182)}$ Mediante relato de história familiar positiva, a mesma variante foi confirmada na irmã do probando com fenótipo semelhante.

Apesar de não alterar a matriz de leitura da proteína, a deleção do ácido glutâmico (Glu) está em uma posição conservada entre as espécies e foi predita como prejudicial à função proteica por todos os algoritmos de análises computacionais in silico. O resíduo 303 está localizado na região C-terminal da proteína torsina $\mathrm{A}$, onde ela interage com KLC1, uma cadeia de subunidade da proteína cinesina I. Essa interação está relacionada com o transporte anterógrado mediado por cinesinas, realizado via citoesqueleto neuronal e como chaperona, também pode regular a atividade da cinesina e a ligação da carga a ser transportada (via KLC1). ${ }^{(93)} \mathrm{O}$ modelo proteico variante demonstrou perda de pontes de hidrogênio de interação entre domínios e alteração na conformação de uma região de loop, que podem estar 
relacionados com a deficiência de ativação dessa proteína via LULL1, conforme demonstrado experimentalmente. ${ }^{(183)}$

Embora o mecanismo fisiopatológico envolvido em DYT-TOR1A ainda não esteja totalmente elucidado, estudos funcionais e modelos animais indicam que a variante p.Glu303del é patogênica, afetando diversos processos nos neurônios dopaminérgicos da SNpc e cerebelo, com níveis mais altos de expressão da proteína alterada em relação à selvagem nessas estruturas. ${ }^{(184)}$ Os processos comprometidos envolvem endocitose de vesículas sinápticas, ${ }^{\left({ }^{89}\right)}$ funcionamento do envelope nuclear em relação citoesqueleto (adquirindo associação mais forte à proteína SYNE), ${ }^{(91)}$ formação de inclusões perinucleares, ${ }^{(96)}$ alterações na atividade estriatal, defeitos na liberação de dopamina e perturbação de vias cerebelares e hipocampais. ${ }^{(44,61)}$

Outra variante identificada foi a c.488C >T / p.(Ala163Val) no éxon 3, em um homem com surgimento dos sintomas na língua aos 25 anos de idade, persistindo na forma focal por 2 anos (até o momento da avaliação clínica). Os sintomas ocorrem mediante uso de instrumento musical (trombone), relacionado com a atuação musical profissional do probando, que não possui história de distonia na família. Essa variante está descrita em todos os bancos de dados populacionais, mas com frequência inferior a $0,1 \%$, seu impacto na função proteica está classificado como "incerto" (segundo o banco de dados ClinVar) e ambos os aminoácidos envolvidos possuem características semelhantes.

Em primeira análise, a variante p.(Ala163Val) parece não impactar a função de torsina $1 \mathrm{~A}$ e não estar relacionada com o fenótipo DYT-TOR1A. Porém, embora as análises in silico não tenham sido concordantes e o aminoácido alterado seja parcialmente conservado ao longo das espécies, a variante causa alterações nas ligações e interações dos aminoácidos adjacentes ao alterado, segundo modelo proteico, e afeta uma região de interação com a proteína SNAPIN. SNAPIN e torsina $1 \mathrm{~A}$ estão co-localizadas em grânulos secretórios de neuritos e atuam na maturação, liberação e recuperação de vesículas sinápticas. A ausência de SNAPIN e de sua interação com torsina $1 \mathrm{~A}$ levam à alteração no processo exo-endocítico e consequente redução no processo de reciclagem vesicular. ${ }^{(89)}$

Além disso, análises de variantes em TOR1A sugerem uma correlação genótipo-fenótipo, com desenvolvimento mais tardio e menos grave em casos onde a variante não é a delGAG no éxon $5 .{ }^{(185)}$ A p.(Ala163Val) e outras variantes que afetam a mesma região proteica parecem estar relacionadas com 
distonia focal de surgimento tardio, geralmente desencadeada por fatores externos, como o uso excessivo de um grupamento muscular. Em outro estudo, a mesma variante foi identificada em um homem com surgimento de distonia na mão aos 26 anos de idade (permanecendo focal por 20 anos) e história familiar positiva, mas sem segregação familiar. Outras variantes foram identificadas em casos de surgimento tardio que permaneceram na forma estática por anos, ${ }^{(181)}$ inclusive uma variante afetando o mesmo domínio proteico (p.F205I) em um caso de distonia focal (oromandibular) de surgimento tardio (47 anos), história familiar negativa e boa resposta ao tratamento com anticolinérgicos, no qual verificou-se agregados proteicos mal-formados no meio intracelular (inclusões intracelulares). ${ }^{(186)}$

\subsection{TUBB4A}

Identificamos em um probando, a variante missense c.883G $>A$ / p.(Asp295Asn) em heterozigose no éxon 4 do gene TUBB4A. Foi identificada em um homem, sem história familiar, com surgimento da distonia no membro superior direito aos 6 anos de idade, generalização dos sintomas ao longo de 24 anos, marcante envolvimento laríngeo e disfonia, sem resposta satisfatória ao tratamento farmacológico (levodopa, benzodiazepínicos e anticolinérgicos) e à aplicação de toxina botulínica. Exceto pelo surgimento precoce dos sintomas, o caso reportado nesse estudo possui fenótipo semelhante aos reportados em outros estudos. ${ }^{(66,187)}$

Como a mesma variante foi confirmada no pai, em duas tias e no irmão do probando, todos assintomáticos, devemos considerar duas possíveis situações: 1. A variante em questão não está relacionada com distonia, e nesse caso, a correlação com o fenótipo de distonia e disfonia sussurante teria sido ao acaso, ou 2. Em DYT-TUBB4A há penetrância reduzida ou influência de polimorfismos de proteção ou susceptibilidade em relação à expressão dos sinais e sintomas clínicos, como descrito em DYT-TOR1A. Ocasionalmente, uma variante de origem materna no gene ATP1A3 (p.Val885lle) foi identificada no mesmo probando, assim como em seu irmão assintomático. Essa variante não atingiu nenhum dos critérios de patogenicidade avaliados nesse estudo, embora possa ser um fator de risco. Até o momento do recrutamento, o irmão do probando, com 30 anos de idade, era assintomático. 
Entretanto, deve ser considerado que na maioria dos casos TUBB4A já descritos a idade de início dos sintomas foi na fase adulta (dos 13 aos 37 anos de idade). ${ }^{(81,82,187)}$

Segundo comparação de modelos proteicos, a variante em questão afeta regiões de interação entre domínios, devido à perda de pontes de ligação entre eles, prejudicando as alterações conformacionais necessárias mediante ativação e oligomerização e o nível de interação de alguns sítios de ligação. A interação correta entre resíduos pertencentes à diferentes domínios da proteína é essencial para a estabilidade do monômero e do sítio ligante de GTP/GDP, assim como para a dinâmica entre os domínios N-terminal e intermediário após hidrólise do GTP e despolimerização do microtúbulo. ${ }^{(179)}$ Portanto, a perda dessas pontes de interação (como observado no modelo D295N) pode contribuir para a desestabilização da beta-tubulina mediante ativação e oligomerização.

\section{$4.3 \mathrm{GCH} 1$}

Variantes heterozigóticas foram identificadas no gene $\mathrm{GCH} 1$ de 2 probandos com distonia dopa-responsiva, mas sem sinais de parkinsonismo. Essas variantes não estavam descritas em bancos de dados populacionais e foram preditas como prejudiciais à função proteica por todos os algoritmos in silico.

A variante c.439C >T / p.(Pro147Ser) no éxon 2, está descrita na base de dados do dbSNP, mas não relacionada com distonia. Essa variante provoca a substituição de um aminoácido apolar por um polar, em uma posição conservada da proteína e afeta um sítio ligante de polipeptídeos (interface homodecamer), ${ }^{(188)}$ comprometendo a interação com outras proteínas, desestabilizando a estrutura central da proteína GTP ciclohidrolase I e interferindo na exposição de sítios ligantes de GTP, segundo o modelo proteico.

Já a variante c.607G>A / p.Gly203Arg no éxon 5 não afeta nenhum domínio diretamente, porém, devido às diferenças físico-químicas dos aminoácidos envolvidos, essa variante também desestabiliza o arcabouço central da proteína, podendo comprometer a atuação dos seus sítios ativos expostos, conforme observado nos modelos moleculares preditos. Além disso, essa variante já foi descrita em outros casos de distonia dopa-responsiva, sendo classificada como "patogênica" segundo o banco de dados ClinVar. ${ }^{(189)}$ 
Considerando o fenótipo de distonia dopa-responsiva dos probandos e as análises de patogenicidade realizadas, ficou evidenciado o comprometimento parcial da função da enzima GTP ciclohidrolase I na síntese de dopamina (devido à heterozigose dos casos). A diminuição de dopamina nos núcleos da base, em especial no estriado, pode ter gerado um desequilíbrio das vias direta e indireta do movimento, atrasando os comandos enviados pela via direta (devido à diminuição da excitação dessa via) e acelerando os comandos enviados pela via indireta (devido à ausência do efeito retardante via receptores D2). Como o quadro resultando dessa deficiência de dopamina seria contrário ao de hipercinesia, podemos especular o envolvimento dos mecanismos de compensação e feedback estriatal, aumentando a entrada excitatória nesse núcleo, gerando movimentos exacerbados. A melhora dos sintomas após administração de levodopa é correspondente à restauração do equilíbrio entre as vias do movimento.

\subsection{TH}

Diversas evidências apontam para a não-patogenicidade da variante c.81G>T / p.(Glu27Asp). Primeiro, DYT-TH é uma causa autossômica recessiva, onde geralmente, portadores heterozigóticos como nesse caso, são assintomáticos. Além disso, a variante envolve aminoácidos bioquimicamente similares (ambos são polares carregados negativamente), não afeta nenhum domínio ou sítio funcional descrito, está em uma região não conservada entre as espécies e foi predita como neutra pela maioria dos algoritmos in silico. Não houve correlação genótipo-fenótipo, foi identificada em uma mulher, sem história familiar, com distonia focal no membro superior direito, de surgimento aos 24 anos e de forma estática por 1 ano. Não foram observados sinais de parkinsonismo e o tratamento com levodopa não foi informado.

\subsection{DDC}

No gene $D D C$, identificamos duas variantes, a substituição c.715A>T:p.(Met239Leu) e uma inserção de 5 nucleotídeos c.568_569insCGATC (p.GIn190Profs*3). 
A variante c.715A $>$ T / p.(Met239Leu) afeta uma região não conservada da proteína dopa descarboxilase e troca aminoácidos com propriedades semelhantes, ambos são apolares de carga neutra. Embora o probando tenha história familiar de distonia, as análises in silico não indicaram quaisquer indícios de patogenicidade da variante e não foram observadas quaisquer alterações no modelo proteico com a variante. Considerando os resultados de patogenicidade e o fenótipo, não foi possível relacionar essa variante com a distonia no probando.

Em contrapartida, a variante c.568_569insCGATC p.(Gln190Profs*3) foi identificada em um probando com distonia-parkinsonismo, de surgimento nos membros durante a infância e generalização. Essa variante resulta em uma proteína menor, com $50 \%$ de seus aminoácidos ausentes, afetando o domínio descarboxilase e perdendo sítios ligantes de fosfato.

Variantes autossômicas recessivas estão relacionadas com o quadro de deficiência de descarboxilase, com fenótipo mais grave que envolve outras desordens motoras e casos onde distonia é a principal característica clínica também foram reportados. ${ }^{(190,191)}$ No caso dessa variante, somente análise funcional da proteína alterada será capaz de evidenciar o grau de comprometimento da função proteica.

\subsection{THAP1}

Uma variante já descrita como patogênica no Brasil( ${ }^{(20,192)}$ foi identificada em heterozigose em seis indivíduos do nosso grupo amostral (3,92\%).

No estudo onde a variante c.289C>T / p.Gln97* foi descrita pela primeira vez, ${ }^{(192)}$ os portadores tiveram o surgimento de distonia entre 6 e 22 anos, nos membros ou região crânio-cervical com progressão para as formas segmentar e generalizada. Nos probandos investigados aqui, o fenótipo foi semelhante, distonia de surgimento precoce nos 5 homens afetados (entre 5 e 22 anos) e surgimento tardio na mulher (45). Os sintomas iniciaram na região cervical (2) ou membros (4), seguido de expansão para multifocal (3) ou generalizada (3).

O códon indicar de término da transcrição formado no começo do éxon 3 não afeta o domínio dedo de zinco mas leva à perda da região Pro-rich (região envolvida na formação de homodímeros), e perda da sequência de localização nuclear (NSL - Nuclear Signal Localization), afetando a função de THAP1 em ligar-se à 
sequências específicas de DNA, reprimindo ou ativando processos de transcrição. ${ }^{(118,193)}$ Além disso, assim como essa variante, mutações de truncamento levam à perda da sequência de localização nuclear, alterando a localização subcelular de THAP1 do núcleo para o citoplasma, caracterizando a disfunção dessa proteína no local de ação necessário. ${ }^{(194)}$

\subsection{SGCE}

O gene SGCE codifica uma proteína da família sarcoglicana, proteínas transmembrana componentes do complexo distrofina-glicoproteína, que atua na ligação do citoesqueleto de actina à matriz extracelular, localizada no complexo de Golgi e na membrana plasmática.

A variante SGCE c.584G>A / p.(Arg195His) está em uma região não-membrana, na face extracelular e não afeta o domínio caderina. Embora tenha baixa frequência nos bancos de dados populacionais, esteja em uma região conservada entre as espécies e tenha sido predita como prejudicial à função proteica pela maioria dos algoritmos in silico, não correlacionou com o fenótipo. O fenótipo foi condizente com a outra variante identificada no gene GNAL do mesmo probando, com distonia focal estática na região cervical de surgimento tardio e sem mioclonia. Além disso, essa variante pode não ter influência no fenótipo devido à baixa penetrância de variantes SGCE. ${ }^{(75)}$

\section{$4.8 C I Z 1$}

Em nossa amostra, identificamos 4 variantes em $C I Z 1$, das quais somente duas afetam isoformas expressas no cérebro.

A variante c.1354 C>A / p.(GIn452Lys) foi identificada em uma mulher com surgimento da distonia na região cervical e membros aos 20 anos, com generalização ao longo de 32 anos. História familiar foi reportada no sobrinho com surgimento dos sintomas aos 4 anos e, possivelmente, na avó paterna. O material biológico dos familiares não estava disponível para análise. Essa variante envolve aminoácidos similares bioquimicamente, afeta uma região rica em glutamina, mas pouco conservada da proteína e não mostrou resultados concordantes na análise in silico. 
A outra variante, c. $2087 \mathrm{~A}>\mathrm{G} /$ p.(Asp696Gly) afeta somente a isoforma 1 de $C l Z 1$, expressa em menores níveis na substância negra e no cerebelo em relação à isoforma $2 .^{(68)}$ Foi identificada em uma mulher sem história familiar, com surgimento dos sintomas aos 27 anos na região cervical, de forma estática e associada com mioclonia nos membros superiores. Predita como prejudicial à função proteica, a troca de um aminoácido polar por um apolar ocorreu em uma posição conservada da proteína, que constitui um sítio ligante de ácido nucléico, com atuação no reconhecimento de DNA.

O mecanismo de atuação da proteína CIZ1 no sistema nervoso central e seu papel fisiopatológico na distonia ainda não está elucidado, o que dificulta a realização de estudos funcionais determinantes. Assim como nesse estudo, os estudos anteriores que identificaram variantes nesse gene em indivíduos com distonia se basearam na conservação do aminoácido entre as espécies e em análises in silico para avaliar o impacto da variante na função proteica. A proteína ClZ1 em sua totalidade possui menor grau de conservação entre as espécies, o que interfere no resultado das análises in silico e deve ser considerado na incerteza de sua classificação como benigna ou neutra. Nos dois casos identificados nesse estudo houve correlação do genótipo observado com o fenótipo descrito de distonia cervical com surgimento na fase adulta. ${ }^{(68)}$

\subsection{GNAL}

Com fenótipo muito característico dessa causa, identificamos 3 variantes nesse gene, uma em cada probando. As afetadas são mulheres, que tiveram surgimento dos sintomas entre 35 e 36 anos de idade, na região cervical, permanecendo focal em duas. História familiar positiva foi relatada somente em um caso.

Nenhuma das variantes foram descritas em indivíduos com distonia e nem em bancos de dados populacionais. As variantes c.658G>T / p.(Asp220Tyr) e c.731A>G / p.(Glu244Gly) foram preditas como patogênica, estão em regiões conservadas da proteína, e mesmo não afetando diretamente nenhum domínio ou sítio funcional, estão muito próxima de tais regiões como a GoLoco, responsável por associar ou não as subunidades da proteína $\mathrm{G}$ mediante ativação. ${ }^{(195)}$ 
Já a variante c.910G>A / p.(Asp304Asn) altera o último aminoácido da região Switch II da proteína Gaolf (região de loop que sofre alteração conformacional após ligação de GTP), ${ }^{(196,197)}$ além de estar próxima aos sítios de interação com as subunidades beta e gama, com a proteína adenilato ciclase e também ao sítio de ligação GoLoco.

Análise dos modelos proteicos preditos indicou comprometimento das interações entre estruturas secundárias da proteína Gaolf, inclusive em regiões que compõem o núcleo de ativação (ligante de GTP) e regiões que sofrem alterações conformacionais após essa ativação. Tais alterações podem interferir na atuação dessa proteína no processo de transdução de sinal que ocorre em neurônios estriatais, desequilibrando as vias do movimento.

Além das variantes no gene GNAL, variantes no gene MPPE1 (não descrito para distonia) também foram identificadas, uma vez que os dois genes se sobrepõem na mesma região genômica. O gene MPPE1 (também conhecido por PGAP5) possui 4 isoformas, das quais a isoforma 1 é a mais longa, com 396 aminoácidos em seu produto proteico. Esse gene codifica a proteína transmembrana metalofosfoesterase I, com expressão no sistema nervoso central, principalmente, em estruturas envolvidas na circuitaria motora como o núcleo caudado, a substância negra e o tálamo. A proteína metalofosfoesterase I atua no transporte de proteínas ancoradas ao retículo endoplasmático, que são direcionadas ao complexo de Golgi para expressão na superfície celular. ${ }^{(198,199)}$

Somente por meio desse estudo, mesmo com a posterior investigação em todos os indivíduos com história familiar do banco RBED, não foi possível estabelecer uma relação causal entre variantes no gene MPPE1 e distonia, porém, cabe destacar que, em sua maioria, as variantes foram preditas como patogênicas e o fenótipo dos probandos envolvidos foi de acometimento cervical e surgimento tardio dos sintomas. No probando com a variante c.1189T>A (p.X397Arg), que leva à perda de um códon de parada de transcrição, o fenótipo foi mais grave, com início dos sintomas na infância e generalização. 


\subsection{ATP1A3}

Aparentemente, as variantes c.1472A $>\mathrm{G} /$ p.(Asn491Ser) e c.2653G >A / p.(Val885lle) identificadas no gene ATP1A3 não possuem efeito patogênico. Nenhuma das duas altera as propriedades bioquímicas dos aminoácidos envolvidos e nem afetam domínios funcionais e regiões transmembrana. As regiões acometidas são parcialmente conservadas entre as espécies e foram preditas como neutras pela maioria dos algoritmos in silico.

Não houve correlação do genótipo com o fenótipo. A variante p.(Asn491Ser) foi identificada em uma mulher com surgimento da distonia na região cervical aos 35 anos de idade, generalizando ao longo de 21 anos. A variante p.(Val885lle), por sua vez, foi identificada em um indivíduo que já possui variante e fenótipo TUBB4A. Em nenhum dos dois probandos foram observados sinais de parkinsonismo, surgimento abrupto e nem resposta ao tratamento com levodopa.

\subsection{PRKRA}

Identificamos variantes PRKRA em seis probandos. A variante patológica c.665C>T / p.Pro222Leu estava presente em seis indivíduos em padrão homozigoto, conforme reportado previamente em casos DYT-PRKRA. ${ }^{(74,200-202)}$

PRKRA codifica a proteína PACT. Normalmente, PACT é inibida pela proteína ligante de RNA TRBP e, em condições de estresse, se dissocia de TRBP e ativa PKR para inibição da síntese proteica. ${ }^{(135)}$ Estudos funcionais demonstraram que a mutação c.665C>T altera a afinidade de PACT, e mediante estresse celular, a proteína alterada leva mais tempo para de dissociar de TRBP e causa uma maior ativação de PKR, atrasando e amplificando a resposta intracelular ao estresse. ${ }^{(137)}$

Em um único probando, identificamos uma heterozigose composta pela mesma variante patogênica c.665C>T / p.Pro222Leu no éxon 7 somada à uma nova variante no éxon 8, c.795C>A / p.(Ser265Arg). Essa alteração ocorre em uma região conservada do domínio 3 na proteína PACT. Não estava descrita nos bancos de dados populacionais, não foi encontrada em 246 cromossomos de controles brasileiros saudáveis e foi predita como deletéria pela maioria das análises in silico. Estudos in 
vitro mostraram que a alteração de vários resíduos nessa região, incluindo o resíduo 265, impedem PACT de se ligar e ativar a proteína PRK. ${ }^{(135)}$

Exceto pela ausência de parkinsonismo (reportada também por outros estudos), a maioria dos probandos apresentou fenótipo semelhante aos outros estudos descritos previamente, com distonia precoce de surgimento focal seguida por generalização e sem resposta ao tratamento anticolinérgico e

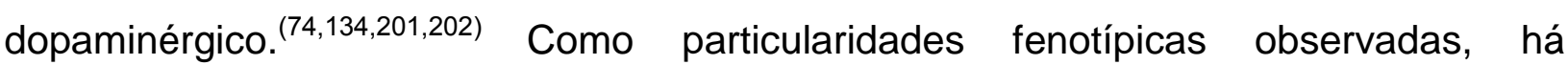
surgimento tardio (aos 25 e 53 anos) em dois probandos, caracterizando o primeiro relato de PRKRA também como causa de distonia com surgimento tardio. Quanto à progressão dos sintomas, não houve progressão em um probando com distonia focal, porém, não é possível afirmar padrão estático devido ao curto período de acompanhamento. Em contrapartida, outro probando permaneceu na forma segmentar 17 anos após o surgimento dos sintomas, sem progressão para a forma generalizada.

Membros afetados das famílias reportadas anteriormente (da Polônia, Itália e Brasil) que portavam a mutação c.665C>T, compartilhavam um trecho de marcadores homozigotos idênticos nas imediações do gene PRKRA, sugerindo um possível efeito fundador nesses casos. ${ }^{(74,201,202)}$ Como membros da família dos probandos incluídos nesse estudo não estavam disponíveis para avaliação, para verificar se a variante c.665C>T em homozigose originou de ancestral comum aos probandos, investigamos 4 variantes polimórficas (rs3997879, rs3997878, rs3997877 e rs150679361) na região 3' UTR e uma inserção frequente (rs150523431), cobertas pelo mesmo painel de sequenciamento. Dois dos seis probandos possuíam marcadores heterozigóticos nessa região, somados a um terceiro probando de etnia japonesa e não miscigenada, sugerindo pelo menos três eventos independentes dessa variante na população brasileira (Tabela 7). 
Tabela 7. Genótipos de marcadores polimórficos na região genômica do PRKRA

\begin{tabular}{|c|c|c|c|c|c|c|c|c|c|c|c|c|c|c|c|c|c|}
\hline \multirow{2}{*}{$\begin{array}{l}\text { Chr } 2 \text { Posição } \\
179296511\end{array}$} & \multirow{2}{*}{$\begin{array}{l}\text { ID snv/ ins } \\
\text { rs3997879 }\end{array}$} & \multirow{2}{*}{$\begin{array}{c}\text { MAF } \\
0.2136\end{array}$} & \multirow{2}{*}{$\begin{array}{l}\text { Ref. } \\
\text { G }\end{array}$} & \multicolumn{14}{|c|}{ Probandos / Genótipos } \\
\hline & & & & \multicolumn{2}{|c|}{1} & \multicolumn{2}{|c|}{2} & \multicolumn{2}{|c|}{3} & \multicolumn{2}{|c|}{4} & \multicolumn{2}{|c|}{5} & \multicolumn{2}{|c|}{6} & \multicolumn{2}{|r|}{7} \\
\hline 179296626 & rs3997878 & 0.2138 & C & C & $T$ & C & $\mathbf{T}$ & $C$ & $\mathrm{C}$ & C & $\mathrm{C}$ & C & C & C & C & $C$ & C \\
\hline 179296971 & rs150679361 & 0.007644 & G & G & $\mathrm{G}$ & G & $\mathrm{G}$ & $G$ & $G$ & G & $G$ & G & $G$ & G & $\mathrm{G}$ & $\mathbf{G}$ & $\mathbf{T}$ \\
\hline *179300991 & rs121434410 & 0.00009905 & c & $\mathrm{T}$ & $T$ & $\mathrm{~T}$ & $\mathrm{~T}$ & T & $T$ & $T$ & $\mathrm{~T}$ & $\mathrm{~T}$ & $\mathrm{~T}$ & $\mathrm{~T}$ & $\mathrm{~T}$ & C & $\mathbf{T}$ \\
\hline 179312440 & rs150523431 & 0.3020 & G & GTAC & GTAC & GTAC & GTAC & GTAC & GTAC & GTAC & GTAC & GTAC & GTAC & GTAC & GTAC & G & GTAC \\
\hline
\end{tabular}




\subsection{KCTD17}

Duas variantes foram identificadas no gene KCTD17, uma em cada probando. A variante c.337G>A / p.(Glu113Lys) está localizada em uma região conservada da proteína KCTD17, dentro de um domínio de interação proteica e responsável pela montagem de canais tetraméricos funcionais. ${ }^{(203)}$ Não está descrita em nenhum dos bancos de dados e foi predita como prejudicial à função proteica por todos os algoritmos in silico. O fenótipo do probando avaliado nesse estudo compartilha do mesmo fenótipo isolado descrito no estudo inicial, portador da variante p.Arg145His. Ambos são do sexo feminino, com início dos sintomas na fase adulta (aproximadamente aos 20 anos), com acometimento da região cervical de forma estática por mais de 20 anos, história familiar positiva e sem sinais de mioclonia. ${ }^{(76)}$

Por outro lado, a variante c. 655G>A / p.(Glu219Lys) parece não estar relacionada com distonia, uma vez que não afeta nenhum domínio ou sítio funcional, está em uma região não conservada da proteína e, principalmente, porque o probando já possui uma variante homozigótica patológica no gene PRKRA com fenótipo característico dessa causa.

\subsection{Limitações do estudo}

Como limitações desse estudo podemos destacar que os dados clínicos dos probandos investigados foram coletados no momento do recrutamento, os quais podem ter variado ao longo do tempo, podendo eventualmente não refletir o atual quadro fenotípico, muito embora a maioria continue em acompanhamento clínico nos centros de recrutamento. Ademais, alguns dados coletados (como por exemplo, local e idade de surgimento dos sintomas) podem ter viés de memória e familiares não estavam disponíveis para análise em todos os casos.

Cabe destacar que, mesmo com as análises in silico realizadas nesse estudo, somente estudos funcionais in vitro e in vivo poderão afirmar com certeza a patogenicidade das variantes identificadas. 


\section{CONCLUSÕES}

1. Padronizamos a análise molecular de 13 genes descritos para distonia, por meio da técnica de ressequenciamento direcionado por painel, assim como, análises de patogenicidade de avaliação das variantes sob diversas perspectivas;

2. Identificamos causas genéticas em $16 \%$ dos casos que permaneceram classificados como idiopáticos, após investigação anterior por método de sequenciamento Sanger. Além disso, descrevemos novas variantes para distonia e confirmamos causas que haviam sido tidas como incertas. Podemos concluir que variantes não delGAG no gene TOR1A podem ser fatores de risco para distonia focal de surgimento no adulto, confirmamos o papel dos genes TUBB4A, CIZ1 e KCTD17 como causa de distonia em nossa amostra, sendo esse o primeiro estudo de confirmação em indivíduos brasileiros e expandimos o espectro fenotípico de variantes $D D C$ em distonia-parkinsonismo, com fenótipo menos grave e sem outras desordens associadas;

3. Considerando o grupo amostral total da Rede Brasileira para estudo das distonias, DTY-THAP1 foi a causa mais comum, seguida por DYT-GCH1. Inusitadamente, DYT-PRKRA não foi uma causa incomum de distonia (na qual história familiar e consanguinidade nem sempre estavam presentes), estando mais frequente em nossa amostra do que casos DYT-TOR1A. Em sua maioria, o genótipo identificado correlaciou com o fenótipo observado no momento do recrutamento;

4. Embora estudos funcionais sejam necessários para confirmar a patogenicidade das variantes identificadas (principalmente nos casos esporádicos), nossos resultados indicam heterogeneidade genética em nossa amostra, tornando o método de sequenciamento por painel em distonia eficaz, principalmente, em casos de início precoce. 


\section{REFERÊNCIAS}

1. Albanese A, Bhatia K, Bressman SB, Delong MR, Fahn S, Fung VS, et al. Phenomenology and classification of dystonia: a consensus update. Mov Disord. 2013;28(7):863-73.

2. Girach A, Vinagre Aragon A, Zis P. Quality of life in idiopathic dystonia: a systematic review. J Neurol. 2019;266(12):2897-906. Review.

3. Truong DD, Fahn S. An early description of dystonia: translation of Schwalbe's thesis and information on his life. Adv Neurol. 1988;50:651-64.

4. Fahn S. Classification of movement disorders. Mov Disord. 2011;26(6):947-57.

5. Klein C, Fahn S. Translation of Oppenheim's 1911 paper on dystonia. Mov Disord. 2013;28(7):851-62. Review.

6. Newby RE, Thorpe DE, Kempster PA, Alty JE. A history of dystonia: ancient to Modern. Mov Disord Clin Pract. 2017;4(4):478-85.

7. Herz E. Dystonia: I. Historical review; analysis of dystonic symptoms and physiologic mechanisms involved. Arch Neurol Psychiatry. 1944;51(4):305-18.

8. Albanese A, Di Giovanni M, Lalli S. Dystonia: diagnosis and management. Eur J Neurol. 2019;26(1):5-17. doi: 10.1111/ene.13762. Epub 2018 Aug 18. Review.

9. Jinnah HA, Factor SA. Diagnosis and treatment of dystonia. Neurol Clin. 2015;33(1):77-100. Review.

10. van Egmond ME, Lugtenberg $\mathrm{CH}$, Brouwer OF, Contarino MF, Fung VS, Heiner-Fokkema $\mathrm{MR}$, et al. A post hoc study on gene panel analysis for the diagnosis of dystonia. Mov Disord. 2017;32(4):569-75.

11. Brasil. Ministério da Saúde. Secretaria de Atenção à Saúde. Departamento de Atenção Especializada e Temática. Coordenação Geral de Média e Alta Complexidade. Diretrizes para atenção integral às pessoas com doenças raras no Sistema Único de Saúde - SUS [Internet]. Brasília (DF): Ministério da Saúde; 2014 [citado 2019 Nov 19]. Disponível em: http://portalarquivos2.saude.gov.br/images/pdf/2014/junho/04/DIRETRIZES-DOENCASRARAS.pdf

12. Jog M, Chouinard S, Hobson D, Grimes D, Chen R, Bhogal M, et al. Causes for treatment delays in dystonia and hemifacial spasm: a Canadian survey. Can J Neurol Sci.

2011;38(5):704-11.

13. Tiderington E, Goodman EM, Rosen AR, Hapner ER, Johns MM, Evatt ML, et al. How long does it take to diagnose cervical dystonia? J Neurol Sci. 2013;335(1-2):72-4.

14. Macerollo A, Superbo M, Gigante AF, Livrea P, Defazio G. Diagnostic delay in adult-onset dystonia: data from an Italian movement disorder center. J Clin Neurosci. 2015;22(3):608-10.

15. Brasil. Ministério da Saúde. Secretaria de Atenção à Saúde. Portaria conjunta n. 1, de 29 de maio de 2017. Aprova o Protocolo Clínico e Diretrizes Terapêuticas de Distonia e Espasmo Hemifacial [Internet]. Brasília (DF): Ministério da Saúde; 2017 [citado 2019 Nov 19]. Disponível 
em: http://portalarquivos2.saude.gov.br/images/pdf/2017/junho/01/MINUTA-de-Portaria-SASPCDT-Distonias-e-Espasmo-19-05-2017.pdf

16. Jinnah HA, Albanese A, Bhatia KP, Cardoso F, Da Prat G, de Koning TJ, et al; International Parkinson's Disease Movement Disorders Society Task Force on Rare Movement Disorders. Treatable inherited rare movement disorders. Mov Disord. 2018;33(1):21-35. Review.

17. Dressler D, Altenmueller E, Bhidayasiri R, Bohlega S, Chana P, Chung TM, et al. Strategies for treatment of dystonia. J Neural Transm (Vienna). 2016;123(3):251-8.

18. Bledsoe IO, Comella CL. Botulinum toxin treatment of cervical dystonia. Semin Neurol. 2016;36(1):47-53.

19. Moro E, LeReun C, Krauss JK, Albanese A, Lin JP, Walleser Autiero S, et al. Efficacy of pallidal stimulation in isolated dystonia: a systematic review and meta-analysis. Eur $\mathrm{J}$ Neurol. 2017;24(4):552-60.

20. Werle RW, Takeda SY, Zonta MB, Guimarães AT, Teive HA. The physical, social and emotional aspects are the most affected in the quality of life of the patients with cervical dystonia. Arq Neuropsiquiatr. 2014;72(6):405-10.

21. Jahanshahi M. Neuropsychological and neuropsychiatric features of idiopathic and DYT1 dystonia and the impact of medical and surgical treatment. Arch Clin Neuropsychol. 2017;32(7):888-905.

22. Nutt JG, Muenter MD, Aronson A, Kurland LT, Melton LJ. Epidemiology of focal and generalized dystonia in Rochester, Minnesota. Mov Disord. 1988;3(3):188-94.

23. Fukuda $\mathrm{H}$, Kusumi M, Nakashima K. Epidemiology of primary focal dystonias in the western area of Tottori prefecture in Japan: comparison with prevalence evaluated in 1993. Mov Disord. 2006;21(9):1503-6.

24. Defazio G, Jankovic J, Giel JL, Papapetropoulos S. Descriptive epidemiology of cervical dystonia. Tremor Other Hyperkinet Mov (N Y). 2013;3. pii: tre-03-193-4374-2.

25. Defazio G. The epidemiology of primary dystonia: current evidence and perspectives. Eur J Neurol. 2010;17 Suppl 1:9-14.

26. Steeves TD, Day L, Dykeman J, Jette N, Pringsheim T. The prevalence of primary dystonia: a systematic review and meta-analysis. Mov Disord. 2012;27(14):1789-96.

27. Warner T, Camfield L, Marsden CD, Nemeth AH, Hyman N, Harley D, et al.; Epidemiological Study of Dystonia in Europe (ESDE) Collaborative Group. A prevalence study of primary dystonia in eight European countries. J Neurol. 2000;247(10):787-92.

28. Castelon Konkiewitz E, Trender-Gerhard I, Kamm C, Warner T, Ben-Shlomo Y, Gasser T, et al. Service-based survey of dystonia in munich. Neuroepidemiology. 2002;21(4):202-6.

29. Müller J, Kiechl S, Wenning GK, Seppi K, Willeit J, Gasperi A, et al. The prevalence of primary dystonia in the general community. Neurology. 2002;59(6):941-3.

30. Matsumoto S, Nishimura M, Shibasaki H, Kaji R. Epidemiology of primary dystonias in Japan: comparison with Western countries. Mov Disord. 2003;18(10):1196-8. 
31. Asgeirsson H, Jakobsson F, Hjaltason H, Jonsdottir H, Sveinbjornsdottir S. Prevalence study of primary dystonia in Iceland. Mov Disord. 2006;21(3):293-8.

32. Das SK, Banerjee TK, Biswas A, Roy T, Raut DK, Chaudhuri A, et al. Community survey of primary dystonia in the city of Kolkata, India. Mov Disord. 2007;22(14):2031-6.

33. Wang L, Chen $\mathrm{Y}, \mathrm{Hu} \mathrm{B}, \mathrm{Hu} \mathrm{X}$. Late-onset primary dystonia in Zhejiang province of China: a service-based epidemiological study. Neurol Sci. 2016;37(1):111-6.

34. Williams L, McGovern E, Kimmich O, Molloy A, Beiser I, Butler JS, et al. Epidemiological, clinical and genetic aspects of adult onset isolated focal dystonia in Ireland. Eur J Neurol. 2017;24(1):73-81.

35. Bezerra TC, Novaretti N, Cunha AL, Pereira MA, Oliveira DS, Brito MC, et al. Epidemiological and clinical aspects of a sample of Brazilian patients with primary dystonia and the impact of the new classification on their clinical evaluation. Arq Neuropsiquiatr. 2018;76(12):821-6.

36. Lent R. Cem Bilhões de neurônios?: conceitos fundamentais de neurociência. 2a ed. São Paulo: Atheneu; 2002.

37. Mink JW. Basal ganglia mechanisms in action selection, plasticity, and dystonia. Eur J Paediatr Neurol. 2018;22(2):225-9.

38. Bhatia KP, Marsden CD. The behavioural and motor consequences of focal lesions of the basal ganglia in man. Brain. 1994;117(Pt 4):859-76.

39. Mink JW. The basal ganglia: focused selection and inhibition of competing motor programs. Prog Neurobiol. 1996;50(4):381-425.

40. Sian J, Youdim MB, Riederer P, Gerlach M. Biochemical anatomy of the basal ganglia and associated neural systems. In: Siegel GJ, Agranoff BW, Albers RW, et al., editors. Basic neurochemistry: molecular, cellular and medical aspects [Internet]. 6th ed. Philadelphia: Lippincott-Raven; 1999 [cited 2019 Nov 19]. Available from:

https://www.ncbi.nlm.nih.gov/books/NBK27905/

41. Herrero MT, Barcia C, Navarro JM. Functional anatomy of thalamus and basal ganglia. Childs Nerv Syst. 2002;18(8):386-404

42. Fazl A, Fleisher J. Anatomy, physiology, and clinical syndromes of the basal ganglia: a brief review. Semin Pediatr Neurol. 2018;25:2-9. Review.

43. Neychev VK, Gross RE, Lehéricy S, Hess EJ, Jinnah HA. The functional neuroanatomy of dystonia. Neurobiol Dis. 2011;42(2):185-201.

44. Jinnah HA, Neychev V, Hess EJ. The anatomical basis for dystonia: the motor network model. Tremor Other Hyperkinet Mov (N Y). 2017;7:506.

45. Pizoli CE, Jinnah HA, Billingsley ML, Hess EJ. Abnormal cerebellar signaling induces dystonia in mice. J Neurosci. 2002;22(17):7825-33.

46. Neychev VK, Fan X, Mitev VI, Hess EJ, Jinnah HA. The basal ganglia and cerebellum interact in the expression of dystonic movement. Brain. 2008;131(Pt 9):2499-509. 
47. Leisman G, Braun-Benjamin O, Melillo R. Cognitive-motor interactions of the basal ganglia in development. Front Syst Neurosci. 2014;8:16.

48. Nambu A. [Functions of direct, indirect and hyperdirect pathways]. Brain Nerve.

2009;61(4):360-72. Review. Japanese.

49. Abudukeyoumu N, Hernandez-Flores T, Garcia-Munoz M, Arbuthnott GW. Cholinergic modulation of striatal microcircuits. Eur J Neurosci. 2019;49(5):604-22. Review.

50. Cepeda C, André VM, Jocoy EL, Levine MS. NMDA and dopamine: diverse mechanisms applied to interacting receptor systems. In: Van Dongen AM, editor. Biology of the NMDA receptor. Boca Raton (FL): CRC Press/Taylor \& Francis; 2009.

51. Govindaiah G, Wang Y, Cox CL. Substance P selectively modulates GABA(A) receptormediated synaptic transmission in striatal cholinergic interneurons. Neuropharmacology. 2010;58(2):413-22.

52. Goodchild RE, Grundmann K, Pisani A. New genetic insights highlight 'old' ideas on motor dysfunction in dystonia. Trends Neurosci. 2013;36(12):717-25.

53. Balint B, Mencacci NE, Valente EM, Pisani A, Rothwell J, Jankovic J, et al. Dystonia. Nat Rev Dis Primers. 2018;4(1):25. Review. Erratum in: Nat Rev Dis Primers. 2018;4(1):37.

54. Lehéricy S, Tijssen MA, Vidailhet M, Kaji R, Meunier S. The anatomical basis of dystonia: current view using neuroimaging. Mov Disord. 2013;28(7):944-57.

55. Lozeron P, Poujois A, Richard A, Masmoudi S, Meppiel E, Woimant F, et al. Contribution of TMS and rTMS in the Understanding of the pathophysiology and in the treatment of dystonia. Front Neural Circuits. 2016;10:90.

56. Tewari A, Fremont $\mathrm{R}$, Khodakhah $\mathrm{K}$. It's not just the basal ganglia: cerebellum as a target for dystonia therapeutics. Mov Disord. 2017;32(11):1537-45.

57. Burciu RG, Hess CW, Coombes SA, Ofori E, Shukla P, Chung JW, et al. Functional activity of the sensorimotor cortex and cerebellum relates to cervical dystonia symptoms. Hum Brain Mapp. 2017;38(9):4563-73.

58. Opavsky R, Hlustik $P$, Kanovsky P. Cortical plasticity and its implications for focal hand dystonia. Biomed Pap Med Fac Univ Palacky Olomouc Czech Repub. 2006;150(2):223-6.

59. Quartarone A, Hallett M. Emerging concepts in the physiological basis of dystonia. Mov Disord. 2013;28(7):958-67.

60. Quartarone A, Ruge D. How many types of dystonia? Pathophysiological considerations. Front Neurol. 2018;9:12.

61. Martella G, Maltese M, Nisticò R, Schirinzi T, Madeo G, Sciamanna G, et al. Regional specificity of synaptic plasticity deficits in a knock-in mouse model of DYT1 dystonia. Neurobiol Dis. 2014;65:124-32.

62. Sharma N. Neuropathology of dystonia. Tremor Other Hyperkinet Mov (N Y). 2019;9:569. Review.

63. Lohmann K, Klein C. Genetics of dystonia: what's known? What's new? What's next? Mov Disord. 2013;28(7):899-905. 
64. Rothwell JC, Edwards M, Huang YZ, Bhatia KP. Physiological studies in carriers of the DYT1 gene mutation. Rev Neurol (Paris). 2003;159(10 Pt 1):880-4.

65. Ozelius LJ, Hewett JW, Page CE, Bressman SB, Kramer PL, Shalish C, et al. The earlyonset torsion dystonia gene (DYT1) encodes an ATP-binding protein. Nat Genet. $1997 ; 17(1): 40-8$.

66. Lohmann K, Wilcox RA, Winkler S, Ramirez A, Rakovic A, Park JS, et al. Whispering dysphonia (DYT4 dystonia) is caused by a mutation in the TUBB4 gene. Ann Neurol. 2013;73(4):537-45.

67. Fuchs T, Gavarini S, Saunders-Pullman R, Raymond D, Ehrlich ME, Bressman SB, et al. Mutations in the THAP1 gene are responsible for DYT6 primary torsion dystonia. Nat Genet. 2009;41(3):286-8.

68. Xiao J, Uitti RJ, Zhao Y, Vemula SR, Perlmutter JS, Wszolek ZK, et al. Mutations in CIZ1 cause adult onset primary cervical dystonia. Ann Neurol. 2012;71(4):458-69.

69. Charlesworth G, Plagnol V, Holmström KM, Bras J, Sheerin UM, Preza E, et al. Mutations in ANO3 cause dominant craniocervical dystonia: ion channel implicated in pathogenesis. Am J Hum Genet. 2012;91(6):1041-50.

70. Fuchs T, Saunders-Pullman R, Masuho I, Luciano MS, Raymond D, Factor S, et al. Mutations in GNAL cause primary torsion dystonia. Nat Genet. 2013;45(1):88-92.

71. Nygaard TG, Wilhelmsen KC, Risch NJ, Brown DL, Trugman JM, Gilliam TC, et al. Linkage mapping of dopa-responsive dystonia (DRD) to chromosome 14q. Nat Genet. 1993;5(4):38691.

72. Lüdecke B, Dworniczak B, Bartholomé K. A point mutation in the tyrosine hydroxylase gene associated with Segawa's syndrome. Hum Genet. 1995;95(1):123-5.

73. de Carvalho Aguiar P, Sweadner KJ, Penniston JT, Zaremba J, Liu L, Caton M, et al. Mutations in the $\mathrm{Na}+/ \mathrm{K}+-\mathrm{ATPase}$ a3 gene ATP1A3 are associated with rapid-onset dystonia parkinsonism. Neuron. 2004;43(2):169-75.

74. Camargos S, Scholz S, Simón-Sánchez J, Paisán-Ruiz C, Lewis P, Hernandez D, et al. DYT16, a novel young-onset dystonia-parkinsonism disorder: identification of a segregating mutation in the stress-response protein PRKRA. Lancet Neurol. 2008;7(3):207-15.

75. Zimprich A, Grabowski M, Asmus F, Naumann M, Berg D, Bertram M, et al. Mutations in the gene encoding $\varepsilon$-sarcoglycan cause myoclonus-dystonia syndrome. Nat Genet. 2001;29(1):669.

76. Mencacci NE, Rubio-Agusti I, Zdebik A, Asmus F, Ludtmann MH, Ryten M, et al. A missense mutation in KCTD17 causes autosomal dominant myoclonus-dystonia. Am J Hum Genet. 2015;96(6):938-47.

77. Wassenberg T, Molero-Luis M, Jeltsch K, Hoffmann GF, Assmann B, Blau N, et al. Consensus guideline for the diagnosis and treatment of aromatic l-amino acid decarboxylase (AADC) deficiency. Orphanet J Rare Dis. 2017;12(1):12. Review.

78. de Carvalho Aguiar P, Fuchs T, Borges V, Lamar KM, Silva SM, Ferraz HB, et al. Screening of Brazilian families with primary dystonia reveals a novel THAP1 mutation and a de novo TOR1A GAG deletion. Mov Disord. 2010;25(16):2854-7. 
79. Camargo CH, Camargos ST, Raskin S, Cardoso FE, Teive HA. Genetic evaluation for TOR1-A (DYT1) in Brazilian patients with dystonia. Arq Neuropsiquiatr. 2014;72(10):753-6.

80. Grundmann K, Laubis-Herrmann U, Bauer I, Dressler D, Vollmer-Haase J, Bauer P, et al. Frequency and phenotypic variability of the GAG deletion of the DYT1 gene in an unselected group of patients with dystonia. Arch Neurol. 2003;60(9):1266-70.

81. Kostić VS, Svetel M, Kabakci K, Ristić A, Petrović I, Schüle B, et al. Intrafamilial phenotypic and genetic heterogeneity of dystonia. J Neurol Sci. 2006;250(1-2):92-6.

82. Risch NJ, Bressman SB, Senthil G, Ozelius LJ. Intragenic cis and trans modification of genetic susceptibility in DYT1 torsion dystonia. Am J Hum Genet. 2007;80(6):1188-93.

83. Bressman SB, Sabatti C, Raymond D, de Leon D, Klein C, Kramer PL, et al. The DYT1 phenotype and guidelines for diagnostic testing. Neurology. 2000;54(9):1746-52.

84. Augood SJ, Penney JB Jr, Friberg IK, Breakefield XO, Young AB, Ozelius LJ, et al. Expression of the early-onset torsion dystonia gene (DYT1) in human brain. Ann Neurol. 1998;43(5):669-73.

85. Shashidharan $\mathrm{P}$, Kramer BC, Walker RH, Olanow CW, Brin MF. Immunohistochemical localization and distribution of torsinA in normal human and rat brain. Brain Res.

2000;853(2):197-206.

86. Liu Z, Zolkiewska A, Zolkiewski M. Characterization of human torsinA and its dystoniaassociated mutant form. Biochem J. 2003;374(Pt 1):117-22.

87. Granata A, Koo SJ, Haucke V, Schiavo G, Warner TT. CSN complex controls the stability of selected synaptic proteins via a torsinA-dependent process. EMBO J. 2011;30(1):181-93.

88. Hewett JW, Tannous B, Niland BP, Nery FC, Zeng J, Li Y, et al. Mutant torsinA interferes with protein processing through the secretory pathway in DYT1 dystonia cells. Proc Natl Acad Sci U S A. 2007;104(17):7271-6.

89. Granata A, Watson R, Collinson LM, Schiavo G, Warner TT. The dystonia-associated protein torsinA modulates synaptic vesicle recycling. J Biol Chem. 2008;283(12):7568-79.

90. Burdette AJ, Churchill PF, Caldwell GA, Caldwell KA. The early-onset torsion dystoniaassociated protein, torsinA, displays molecular chaperone activity in vitro. Cell Stress Chaperones. 2010;15(5):605-17.

91. Nery FC, Zeng J, Niland BP, Hewett J, Farley J, Irimia D, Li Y, Wiche G, Sonnenberg A, Breakefield XO. TorsinA binds the KASH domain of nesprins and participates in linkage between nuclear envelope and cytoskeleton. J Cell Sci. 2008;121(Pt 20):3476-86.

92. Callan AC, Bunning S, Jones OT, High S, Swanton E. Biosynthesis of the dystoniaassociated AAA+ ATPase torsinA at the endoplasmic reticulum. Biochem J. 2007;401(2):60712.

93. Kamm C, Boston H, Hewett J, Wilbur J, Corey DP, Hanson PI, et al. The early onset dystonia protein torsinA interacts with kinesin light chain 1. J Biol Chem. 2004;279(19):1988292.

94. Hanson PI, Whiteheart SW. AAA+ proteins: have engine, will work. Nat Rev Mol Cell Biol. 2005;6(7):519-29. Review. 
95. Zhu L, Wrabl JO, Hayashi AP, Rose LS, Thomas PJ. The torsin-family AAA+ protein OOC-5 contains a critical disulfide adjacent to Sensor-II that couples redox state to nucleotide binding. Mol Biol Cell. 2008;19(8):3599-612.

96. Shashidharan $P$, Sandu D, Potla U, Armata IA, Walker RH, McNaught KS, et al. Transgenic mouse model of early-onset DYT1 dystonia. Hum Mol Genet. 2005;14(1):125-33.

97. Ghilardi MF, Carbon M, Silvestri G, Dhawan V, Tagliati M, Bressman S, et al. Impaired sequence learning in carriers of the DYT1 dystonia mutation. Ann Neurol. 2003;54(1):102-9.

98. Aravamuthan BR, Waugh JL, Stone SS. Deep brain stimulation for monogenic dystonia. Curr Opin Pediatr. 2017;29(6):691-6.

99. Simons C, Wolf NI, McNeil N, Caldovic L, Devaney JM, Takanohashi A, et al. A de novo mutation in the $\beta$-tubulin gene TUBB4A results in the leukoencephalopathy hypomyelination with atrophy of the basal ganglia and cerebellum. Am J Hum Genet. 2013;92(5):767-73.

100. Ferreira C, Poretti A, Cohen J, Hamosh A, Naidu S. Novel TUBB4A mutations and expansion of the neuroimaging phenotype of hypomyelination with atrophy of the basal ganglia and cerebellum (H-ABC). Am J Med Genet A. 2014;164A(7):1802-7.

101. Purnell SM, Bleyl SB, Bonkowsky JL. Clinical exome sequencing identifies a novel TUBB4A mutation in a child with static hypomyelinating leukodystrophy. Pediatr Neurol. 2014;50(6):608-11.

102. Curiel J, Rodríguez Bey G, Takanohashi A, Bugiani M, Fu X, Wolf NI, et al. TUBB4A mutations result in specific neuronal and oligodendrocytic defects that closely match clinically distinct phenotypes. Hum Mol Genet. 2017;26(22):4506-18.

103. Watanabe N, Itakaoka M, Seki Y, Morimoto T, Homma K, Miyamoto Y, et al. Dystonia-4 (DYT4)-associated TUBB4A mutants exhibit disorganized microtubule networks and inhibit neuronal process growth. Biochem Biophys Res Commun. 2018;495(1):346-52.

104. Vemula SR, Xiao J, Bastian RW, Momčilović D, Blitzer A, LeDoux MS. Pathogenic variants in TUBB4A are not found in primary dystonia. Neurology. 2014;82(14):1227-30.

105. Zech M, Boesch S, Jochim A, Graf S, Lichtner P, Peters A, et al. Large-scale TUBB4A mutational screening in isolated dystonia and controls. Parkinsonism Relat Disord. 2015;21(10):1278-81.

106. de Gusmão CM, Fuchs T, Moses A, Multhaupt-Buell T, Song PC, Ozelius LJ, et al. Dystonia-causing mutations as a contribution to the etiology of spasmodic dysphonia. Otolaryngol Head Neck Surg. 2016;155(4):624-8.

107. Vulinovic F, Krajka V, Hausrat TJ, Seibler P, Alvarez-Fischer D, Madoev H, et al. Motor protein binding and mitochondrial transport are altered by pathogenic TUBB4A variants. Hum Mutat. 2018;39(12):1901-15.

108. Ichinose H, Ohye T, Takahashi E, Seki N, Hori T, Segawa M, et al. Hereditary progressive dystonia with marked diurnal fluctuation caused by mutations in the GTP cyclohydrolase I gene. Nat Genet. 1994;8(3):236-42. 
109. Furukawa Y, Kish SJ, Bebin EM, Jacobson RD, Fryburg JS, Wilson WG, et al. Dystonia with motor delay in compound heterozygotes for GTP-cyclohydrolase I gene mutations. Ann Neurol. 1998;44(1):10-6.

110. Haavik J, Toska K. Tyrosine hydroxylase and Parkinson's disease. Mol Neurobiol. 1998;16(3):285-309.

111. Bademci G, Edwards TL, Torres AL, Scott WK, Züchner S, Martin ER, et al. A rare novel deletion of the tyrosine hydroxylase gene in Parkinson disease. Hum Mutat.

2010;31(10):E1767-71.

112. Bademci G, Vance JM, Wang L. Tyrosine hydroxylase gene: another piece of the genetic puzzle of Parkinson's disease. CNS Neurol Disord Drug Targets. 2012;11(4):469-81.

113. Furukawa Y, Nygaard TG, Gütlich M, Rajput AH, Pifl C, DiStefano L, et al. Striatal biopterin and tyrosine hydroxylase protein reduction in dopa-responsive dystonia. Neurology.

1999;53(5):1032-41.

114. Weisheit CE, Pappas SS, Dauer WT. Inherited dystonias: clinical features and molecular pathways. Handb Clin Neurol. 2018;147:241-54. Review.

115. Chang YT, Sharma R, Marsh JL, McPherson JD, Bedell JA, Knust A, et al. Levodoparesponsive aromatic L-amino acid decarboxylase deficiency. Ann Neurol. 2004;55(3):435-8.

116. Himmelreich N, Montioli R, Bertoldi M, Carducci C, Leuzzi V, Gemperle C, et al. Aromatic amino acid decarboxylase deficiency: molecular and metabolic basis and therapeutic outlook. Mol Genet Metab. 2019;127(1):12-22. Review.

117. Bressman SB, Raymond D, Fuchs T, Heiman GA, Ozelius LJ, Saunders-Pullman R. Mutations in THAP1 (DYT6) in early-onset dystonia: a genetic screening study. Lancet Neurol. 2009;8(5):441-6.

118. Richter A, Hollstein R, Hebert E, Vulinovic F, Eckhold J, Osmanovic A, et al. In-depth Characterization of the Homodimerization Domain of the Transcription Factor THAP1 and Dystonia-Causing Mutations Therein. J Mol Neurosci. 2017;62(1):11-6.

119. Zhao Y, Xiao J, Gong S, Clara JA, Ledoux MS. Neural expression of the transcription factor THAP1 during development in rat. Neuroscience. 2013;231:282-95.

120. da Silva-Junior FP, dos Santos CO, Silva SM, Barbosa ER, Borges V, Ferraz HB, et al. Novel THAP1 variants in Brazilian patients with idiopathic isolated dystonia. J Neurol Sci. 2014;344(1-2):190-2.

121. Gajos A, Golańska E, Sieruta M, Szybka M, Liberski PP, Bogucki A. High variability of clinical symptoms in a Polish family with a novel THAP1 mutation. Int J Neurosci.

2015;125(10):755-9.

122. Carbon M, Su S, Dhawan V, Raymond D, Bressman S, Eidelberg D. Regional metabolism in primary torsion dystonia: effects of penetrance and genotype. Neurology. 2004;62(8):138490 .

123. Carbon M, Niethammer M, Peng S, Raymond D, Dhawan V, Chaly T, et al. Abnormal striatal and thalamic dopamine neurotransmission: genotype-related features of dystonia. Neurology. 2009;72(24):2097-103. 
124. Ritz K, van Schaik BD, Jakobs ME, van Kampen AH, Aronica E, Tijssen MA, et al. SGCE isoform characterization and expression in human brain: implications for myoclonus-dystonia pathogenesis? Eur J Hum Genet. 2011;19(4):438-44.

125. Grabowski M, Zimprich A, Lorenz-Depiereux B, Kalscheuer V, Asmus F, Gasser T, et al. The epsilon-sarcoglycan gene (SGCE), mutated in myoclonus-dystonia syndrome, is maternally imprinted. Eur J Hum Genet. 2003;11(2):138-44.

126. Esapa CT, Waite A, Locke M, Benson MA, Kraus M, Mcllhinney RA, et al. SGCE missense mutations that cause myoclonus-dystonia syndrome impair $\varepsilon$-sarcoglycan trafficking to the plasma membrane: modulation by ubiquitination and torsinA. Hum Mol Genet. 2007;16(3):32742.

127. Zhang L, Yokoi F, Parsons DS, Standaert DG, Li Y. Alteration of striatal dopaminergic neurotransmission in a mouse model of DYT11 myoclonus-dystonia. PLoS One.

2012;7(3):e33669.

128. Yokoi F, Dang MT, Yang G, Li J, Doroodchi A, Zhou T, et al. Abnormal nuclear envelope in the cerebellar Purkinje cells and impaired motor learning in DYT11 myoclonus-dystonia mouse models. Behav Brain Res. 2012;227(1):12-20.

129. Yokoi F, Dang MT, Zhou T, Li Y. Abnormal nuclear envelopes in the striatum and motor deficits in DYT11 myoclonus-dystonia mouse models. Hum Mol Genet. 2012;21(4):916-25.

130. Maltese M, Martella G, Imbriani P, Schuermans J, Billion K, Sciamanna G, et al. Abnormal striatal plasticity in a DYT11/SGCE myoclonus dystonia mouse model is reversed by adenosine A2A receptor inhibition. Neurobiol Dis. 2017;108:128-39.

131. McGrail KM, Phillips JM, Sweadner KJ. Immunofluorescent localization of three Na,KATPase isozymes in the rat central nervous system: both neurons and glia can express more than one Na,K-ATPase. J Neurosci. 1991;11(2):381-91.

132. Fremont R, Calderon DP, Maleki S, Khodakhah K. Abnormal high-frequency burst firing of cerebellar neurons in rapid-onset dystonia-parkinsonism. J Neurosci. 2014;34(35):11723-32.

133. Sugimoto H, Ikeda K, Kawakami K. Heterozygous mice deficient in Atp1a3 exhibit motor deficits by chronic restraint stress. Behav Brain Res. 2014;272:100-10.

134. de Carvalho Aguiar P, Borges V, Ferraz HB, Ozelius LJ. Novel compound heterozygous mutations in PRKRA cause pure dystonia. Mov Disord. 2015;30(6):877-8.

135. Peters GA, Dickerman B, Sen GC. Biochemical analysis of PKR activation by PACT. Biochemistry. 2009;48(31):7441-7.

136. Kok KH, Ng MH, Ching YP, Jin DY. Human TRBP and PACT directly interact with each other and associate with dicer to facilitate the production of small interfering RNA. J Biol Chem. 2007;282(24):17649-57.

137. Vaughn LS, Bragg DC, Sharma N, Camargos S, Cardoso F, Patel RC. Altered activation of protein kinase PKR and enhanced apoptosis in dystonia cells carrying a mutation in PKR activator protein PACT. J Biol Chem. 2015;290(37):22543-57.

138. Burnett SB, Vaughn LS, Strom JM, Francois A, Patel RC. A truncated PACT protein resulting from a frameshift mutation reported in movement disorder DYT16 triggers caspase activation and apoptosis. J Cell Biochem. 2019;120(11):19004-18. 
139. Mitsui K, Matsumoto A, Ohtsuka S, Ohtsubo M, Yoshimura A. Cloning and characterization of a novel p21(Cip1/Waf1)-interacting zinc finger protein, ciz1. Biochem Biophys Res Commun. 1999;264(2):457-64.

140. Coverley D, Marr J, Ainscough J. Ciz1 promotes mammalian DNA replication. J Cell Sci. 2005;118(Pt 1):101-12.

141. Ainscough JF, Rahman FA, Sercombe H, Sedo A, Gerlach B, Coverley D. C-terminal domains deliver the DNA replication factor Ciz1 to the nuclear matrix. J Cell Sci. 2007;120(Pt 1):115-24.

142. Ma L, Chen R, Wang L, Yang Y, Wan X. No mutations in ClZ1 in twelve adult-onset primary cervical dystonia families. Mov Disord. 2013;28(13):1899-901.

143. Dufke C, Hauser AK, Sturm M, Fluhr S, Wächter T, Leube B, et al. Mutations in CIZ1 are not a major cause for dystonia in Germany. Mov Disord. 2015;30(5):740-3.

144. Stamelou M, Charlesworth G, Cordivari C, Schneider SA, Kägi G, Sheerin UM, et al. The phenotypic spectrum of DYT24 due to ANO3 mutations. Mov Disord. 2014;29(7):928-34.

145. Blackburn PR, Zimmermann MT, Gass JM, Harris KG, Cousin MA, Boczek NJ, et al. A novel ANO3 variant identified in a 53-year-old woman presenting with hyperkinetic dysarthria, blepharospasm, hyperkinesias, and complex motor tics. BMC Med Genet. 2016;17(1):93.

146. Zech M, Boesch S, Jochim A, Weber S, Meindl T, Schormair B, et al. Clinical exome sequencing in early-onset generalized dystonia and large-scale resequencing follow-up. Mov Disord. 2017;32(4):549-59.

147. Zech M, Gross N, Jochim A, Castrop F, Kaffe M, Dresel C, et al. Rare sequence variants in ANO3 and GNAL in a primary torsion dystonia series and controls. Mov Disord. 2014;29(1):143-7.

148. Olschewski L, Jesús S, Kim HJ, Tunc S, Löns S, Junker J, et al. Role of ANO3 mutations in dystonia: A large-scale mutational screening study. Parkinsonism Relat Disord. 2019;62:196200.

149. Picollo A, Malvezzi M, Accardi A. TMEM16 proteins: unknown structure and confusing functions. J Mol Biol. 2015;427(1):94-105.

150. Vemula SR, Puschmann A, Xiao J, Zhao Y, Rudzińska M, Frei KP, et al. Role of Ga(olf) in familial and sporadic adult-onset primary dystonia. Hum Mol Genet. 2013;22(12):2510-9.

151. Pelosi A, Menardy F, Popa D, Girault JA, Hervé D. Heterozygous Gnal mice are a novel animal model with which to study dystonia pathophysiology. J Neurosci. 2017;37(26):6253-67.

152. Masuho I, Fang M, Geng C, Zhang J, Jiang H, Özgul RK, et al. Homozygous GNAL mutation associated with familial childhood-onset generalized dystonia. Neurol Genet. 2016;2(3):e78.

153. Geoghegan AR, Al Hussona M, Beauchamp NJ, Hutchinson M, Sean O'Riordan MB, Lynch T, et al. A novel GNAL mutation in familial dystonia presenting with childhood tremor and myoclonus. Mov Disord. 2019;34(6):923-4.

154. O'Connor A, Buckley M, O'Sullivan SS. Teenage Onset Head Tremor Due to Novel Mutation in GNAL Gene. Mov Disord Clin Pract. 2017;4(6):903-4. 
155. Ahn JH, Kim AR, Kim NK, Park WY, Kim JS, Kim M, et al. The Effect of globus pallidus interna deep brain stimulation on a dystonia patient with the GNAL mutation compared to patients with DYT1 and DYT6. J Mov Disord. 2019;12(2):120-4.

156. Marcé-Grau A, Correa M, Vanegas MI, Muñoz-Ruiz T, Ferrer-Aparicio S, Baide $H$, et al. Childhood onset progressive myoclonic dystonia due to a de novo KCTD17 splicing mutation. Parkinsonism Relat Disord. 2019;61:7-9.

157. Graziola F, Stregapede F, Travaglini L, Garone G, Verardo M, Bosco L, et al. A novel KCTD17 mutation is associated with childhood early-onset hyperkinetic movement disorder. Parkinsonism Relat Disord. 2019;61:4-6.

158. Reale C, Panteghini C, Carecchio M, Garavaglia B. The relevance of gene panels in movement disorders diagnosis: A lab perspective. Eur J Paediatr Neurol. 2018;22(2):285-91.

159. Jinnah HA, Alterman R, Klein C, Krauss JK, Moro E, Vidailhet M, et al. Deep brain stimulation for dystonia: a novel perspective on the value of genetic testing. J Neural Transm (Vienna). 2017;124(4):417-30.

160. dos Santos CO, Masuho I, da Silva-Júnior FP, Barbosa ER, Silva SM, Borges V, et al. Screening of GNAL variants in Brazilian patients with isolated dystonia reveals a novel mutation with partial loss of function. J Neurol. 2016;263(4):665-8.

161. Naslavsky MS, Yamamoto GL, de Almeida TF, Ezquina SA, Sunaga DY, Pho N, et al. Exomic variants of an elderly cohort of Brazilians in the ABraOM database. Hum Mutat. 2017;38(7):751-63.

162. Burn J, Watson M. The Human Variome Project. Hum Mutat. 2016;37(6):505-7.

163. Richards S, Aziz N, Bale S, Bick D, Das S, Gastier-Foster J, et al.; ACMG Laboratory Quality Assurance Committee. Standards and guidelines for the interpretation of sequence variants: a joint consensus recommendation of the American College of Medical Genetics and Genomics and the Association for Molecular Pathology. Genet Med. 2015;17(5):405-24.

164. Liu Y, Wei X, Kong X, Guo X, Sun Y, Man J, et al. Targeted next-generation sequencing for clinical diagnosis of 561 Mendelian diseases. PLoS One. 2015;10(8):e0133636.

165. Ye K, Schulz MH, Long Q, Apweiler R, Ning Z. Pindel: a pattern growth approach to detect break points of large deletions and medium sized insertions from paired-end short reads.

Bioinformatics. 2009;25(21):2865-71.

166. Smigielski EM, Sirotkin K, Ward M, Sherry ST. dbSNP: a database of single nucleotide polymorphisms. Nucleic Acids Res. 2000;28(1):352-5.

167. Abecasis GR, Altshuler D, Auton A, Brooks LD, Durbin RM, Gibbs RA, et al.; 1000 Genomes Project Consortium. A map of human genome variation from population-scale sequencing. Nature. 2010;467(7319):1061-73.

168. Lek M, Karczewski KJ, Minikel EV, Samocha KE, Banks E, Fennell T, et al.; Exome Aggregation Consortium. Analysis of protein-coding genetic variation in 60,706 humans. Nature. 2016;536(7616):285-91. 
169. Landrum MJ, Lee JM, Riley GR, Jang W, Rubinstein WS, Church DM, et al. ClinVar: public archive of relationships among sequence variation and human phenotype. Nucleic Acids Res. 2014;42(Database issue):D980-5.

170. Fokkema IF, Taschner PE, Schaafsma GC, Celli J, Laros JF, den Dunnen JT. LOVD v.2.0: the next generation in gene variant databases. Hum Mutat. 2011;32(5):557-63.

171. Kelley LA, Mezulis S, Yates CM, Wass MN, Sternberg MJ. The Phyre2 web portal for protein modeling, prediction and analysis. Nat Protoc. 2015;10(6):845-58.

172. Ray A, Lindahl E, Wallner B. Improved model quality assessment using ProQ2. BMC Bioinformatics. 2012;13:224.

173. Ward JJ, McGuffin LJ, Bryson K, Buxton BF, Jones DT. The DISOPRED server for the prediction of protein disorder. Bioinformatics. 2004 Sep;20(13):2138-9.

174. Le Guilloux V, Schmidtke P, Tuffery P. Fpocket: an open source platform for ligand pocket detection. BMC Bioinformatics. 2009;10:168.

175. Wass MN, Kelley LA, Sternberg MJ. 3DLigandSite: predicting ligand-binding sites using similar structures. Nucleic Acids Res. 2010;38(Web Server issue):W469-73.

176. Nogales E, Wolf SG, Downing KH. Structure of the $\alpha \beta$ tubulin dimer by electron crystallography. Nature. 1998;391(6663):199-203.

177. Amos LA. Focusing-in on microtubules. Curr Opin Struct Biol. 2000;10(2):236-41.

178. McKean PG, Vaughan S, Gull K. The extended tubulin superfamily. J Cell Sci. 2001;114(Pt 15):2723-33.

179. Löwe J, Li H, Downing KH, Nogales E. Refined structure of $\alpha \beta$-tubulin at 3.5 A resolution. J Mol Biol. 2001;313(5):1045-57.

180. Liu X, Xu X, Hilger D, Aschauer P, Tiemann JK, Du Y, et al. Structural Insights into the Process of GPCR-G Protein Complex Formation. Cell. 2019;177(5):1243-51

181. Zech M, Jochim A, Boesch S, Weber S, Meindl T, Peters A, et al. Systematic TOR1A nonc.907_909delGAG variant analysis in isolated dystonia and controls. Parkinsonism Relat Disord. 2016;31:119-23.

182. Hettich J, Ryan SD, de Souza ON, Saraiva Macedo Timmers LF, Tsai S, Atai NA, et al. Biochemical and cellular analysis of human variants of the DYT1 dystonia protein, TorsinA/TOR1A. Hum Mutat. 2014;35(9):1101-13.

183. Demircioglu FE, Sosa BA, Ingram J, Ploegh HL, Schwartz TU. Structures of TorsinA and its disease-mutant complexed with an activator reveal the molecular basis for primary dystonia. Elife. 2016;5. pii: e17983.

184. Armata IA, Diplas AI, Ozelius LJ, Shashidharan P. Allelic Imbalance in TOR1A mRNA Expression in Manifesting and Non-Manifesting Carriers of the GAG-Deletion. J Nucleic Acids. 2012;2012:985260.

185. Dobricic V, Kresojevic N, Zarkovic M, Tomic A, Marjanovic A, Westenberger A, et al. Phenotype of non-c.907_909delGAG mutations in TOR1A: DYT1 dystonia revisited.

Parkinsonism Relat Disord. 2015;21(10):1256-9. 
186. Calakos N, Patel VD, Gottron M, Wang G, Tran-Viet KN, Brewington D, et al. Functional evidence implicating a novel TOR1A mutation in idiopathic, late-onset focal dystonia. J Med Genet. 2010;47(9):646-50.

187. Hersheson J, Mencacci NE, Davis M, MacDonald N, Trabzuni D, Ryten M, et al. Mutations in the autoregulatory domain of beta-tubulin 4a cause hereditary dystonia. Ann Neurol. 2013;73(4):546-53.

188. Nar H, Huber R, Meining W, Bracher A, Fischer M, Hosl C, et al. Structure and mechanism of GTP cyclohydrolase I of Escherichia coli. Biochem Soc Trans. 1996;24(1):37S.

189. Bandmann O, Valente EM, Holmans $P$, Surtees RA, Walters JH, Wevers RA, et al. Doparesponsive dystonia: a clinical and molecular genetic study. Ann Neurol. 1998;44(4):649-56.

190. Brun L, Ngu LH, Keng WT, Ch'ng GS, Choy YS, Hwu WL, et al. Clinical and biochemical features of aromatic L-amino acid decarboxylase deficiency. Neurology. 2010;75(1):64-71.

191. Tay SK, Poh KS, Hyland K, Pang YW, Ong HT, Low PS, et al. Unusually mild phenotype of AADC deficiency in 2 siblings. Mol Genet Metab. 2007;91(4):374-8.

192. Camargo CH, Camargos ST, Raskin S, Cardoso FE, Teive HA. DYT6 in Brazil: Genetic Assessment and Clinical Characteristics of Patients. Tremor Other Hyperkinet Mov (N Y). 2014;4(226):eCollection 2014.

193. Roussigne M, Cayrol C, Clouaire T, Amalric F, Girard JP. THAP1 is a nuclear proapoptotic factor that links prostate-apoptosis-response-4 (Par-4) to PML nuclear bodies. Oncogene. 2003;22(16):2432-42.

194. Cheng FB, Wan XH, Feng JC, Ma LY, Hou B, Feng F, et al. Subcellular distribution of THAP1 and alterations in the microstructure of brain white matter in DYT6 dystonia.

Parkinsonism Relat Disord. 2012;18(8):978-82.

195. Kimple RJ, Kimple ME, Betts L, Sondek J, Siderovski DP. Structural determinants for GoLoco-induced inhibition of nucleotide release by Galpha subunits. Nature.

2002;416(6883):878-81.

196. Sunahara RK, Tesmer JJ, Gilman AG, Sprang SR. Crystal structure of the adenylyl cyclase activator Gsalpha. Science. 1997;278(5345):1943-7.

197. Sprang SR. G protein mechanisms: insights from structural analysis. Annu Rev Biochem. 1997;66:639-78.

198. Vuoristo JT, Ala-Kokko L. cDNA cloning, genomic organization and expression of the novel human metallophosphoesterase gene MPPE1 on chromosome 18p11.2. Cytogenet Cell Genet. 2001;95(1-2):60-3.

199. Fujita M, Maeda Y, Ra M, Yamaguchi Y, Taguchi R, Kinoshita T. GPI glycan remodeling by PGAP5 regulates transport of GPI-anchored proteins from the ER to the Golgi. Cell. 2009;139(2):352-65.

200. Lemmon ME, Lavenstein B, Applegate CD, Hamosh A, Tekes A, Singer HS. A novel presentation of DYT 16: acute onset in infancy and association with MRI abnormalities. Mov Disord. 2013;28(14):1937-8. 
201. Zech M, Castrop F, Schormair B, Jochim A, Wieland T, Gross N, et al. DYT16 revisited: exome sequencing identifies PRKRA mutations in a European dystonia family. Mov Disord. 2014;29(12):1504-10.

202. Quadri M, Olgiati S, Sensi M, Gualandi F, Groppo E, Rispoli V, et al. PRKRA Mutation Causing Early-Onset Generalized Dystonia-Parkinsonism (DYT16) in an Italian Family. Mov Disord. 2016;31(5):765-7.

203. Aravind L, Koonin EV. Fold prediction and evolutionary analysis of the POZ domain: structural and evolutionary relationship with the potassium channel tetramerization domain. $J$ Mol Biol. 1999;285(4):1353-61. 


\section{Abstract}

Introduction: Dystonia is a movement disorder of neurological order, characterized by involuntary contractions that lead to abnormal movements and postures, or both, that can occur in an isolated part or in the whole body. Studies in dystonia have advanced due to improvement of sequencing technologies. The discovery of novel genes and pathogenic allelic variants allowed the identification of proteins involved in the pathophysiology of dystonia implicated in several metabolic pathways when dysfunctional. Actually, genetic diagnosis in dystonia is already an element used to define prognosis, useful in indication of specific treatments, especially in relation to surgical treatment, and reclassification of sporadic or familial cases considered idiopathic. Purpose: This project aimed to standardize the molecular analysis of the main genes described, identifying potentially pathogenic variants in Brazilian individuals with idiopathic dystonia, to characterizing them according their pathogenic potential and to establish genotype - phenotype correlations. Methods: Through the project "Brazilian Network for the Study of Dystonia", 153 individuals with isolated or combined idiopathic dystonia, were investigated for allelic variants in TOR1A, TUBB4A, GCH1, TH, DDC, THAP1, SGCE, ATP1A3, PRKRA, CIZ1, ANO3, GNAL and KCTD17 genes by a custom amplicon-based assay for targeted resequencing (TruSeq ${ }^{\circledR}$ Custom Amplicon) in the MiSeq system (Illumina). The obtained sequences were aligned to human genome reference and allelic variants were characterized by in silico analysis according its pathogenic potential and correlation with the phenotype. To date, in silico homology molecular modeling was performed to evaluate the impact of variants on protein function and conformation. Results: In this study, in $16 \%$ of the probands, we identified 25 allelic variants with a possible causal contribution to dystonia in most genes investigated in the panel, including variants already established as cause of dystonia in the TOR1A, THAP1, GCH1, and PRKRA genes. Unusually, DYT-PRKRA was a major cause of dystonia in our sample, accounting for about $4 \%$ of cases, without parkinsonism. Novel variants in the CIZ1, GNAL, and KCTD17 genes correlated with the phenotype of cervical dystonia with onset in adulthood, but myoclonus described in DYT-KCTD17 cases was not observed in the proband of this study. In DDC gene, we identified a frameshift insertion and premature stop codon with high impact on protein function, according to in silico analyzes, in case of dystonia-parkinsonism. 
Conclusions: Through this study, it was possible to confirm the role of the TUBB4A, CIZ1 and KCTD17 genes as cause of dystonia in our sample, this being the first confirmatory study in Brazilian individuals. Unlike other studies, PRKRA was a frequent cause. In addition, we described ten novel variants characterized according to pathogenic potential. Regarding the etiology of dystonia, although functional studies are necessary to confirm the pathogenicity of the variants identified in this study, our results showed genetic causes among idiopathic cases in our sample, with greater efficacy in cases with early onset.

Keywords: Dystonia/genetics; Genetic variation; Movement disorders 